JOURNAL OF

CAVE AND KARST

STUDIES
June 2020

Volume 82 , Number 2

ISSN 1090-6924

A Publication of the National

Speleological Society

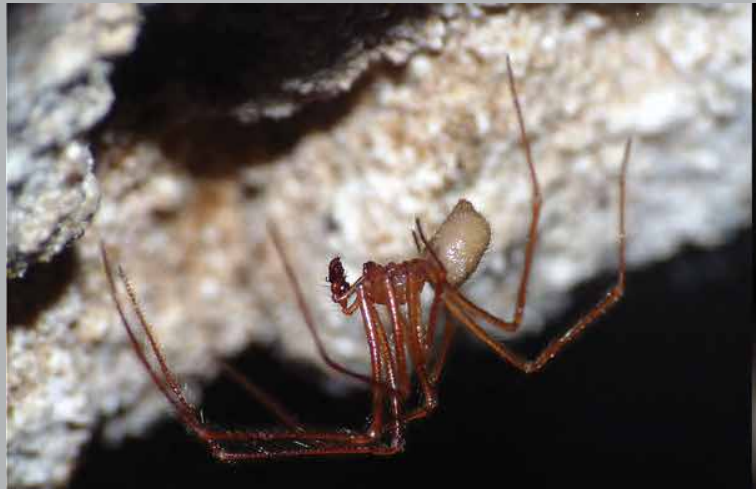

A

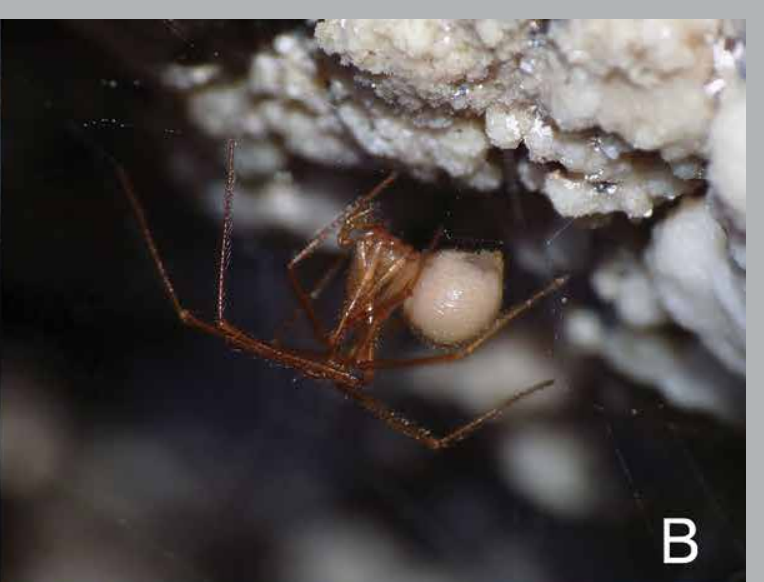

B
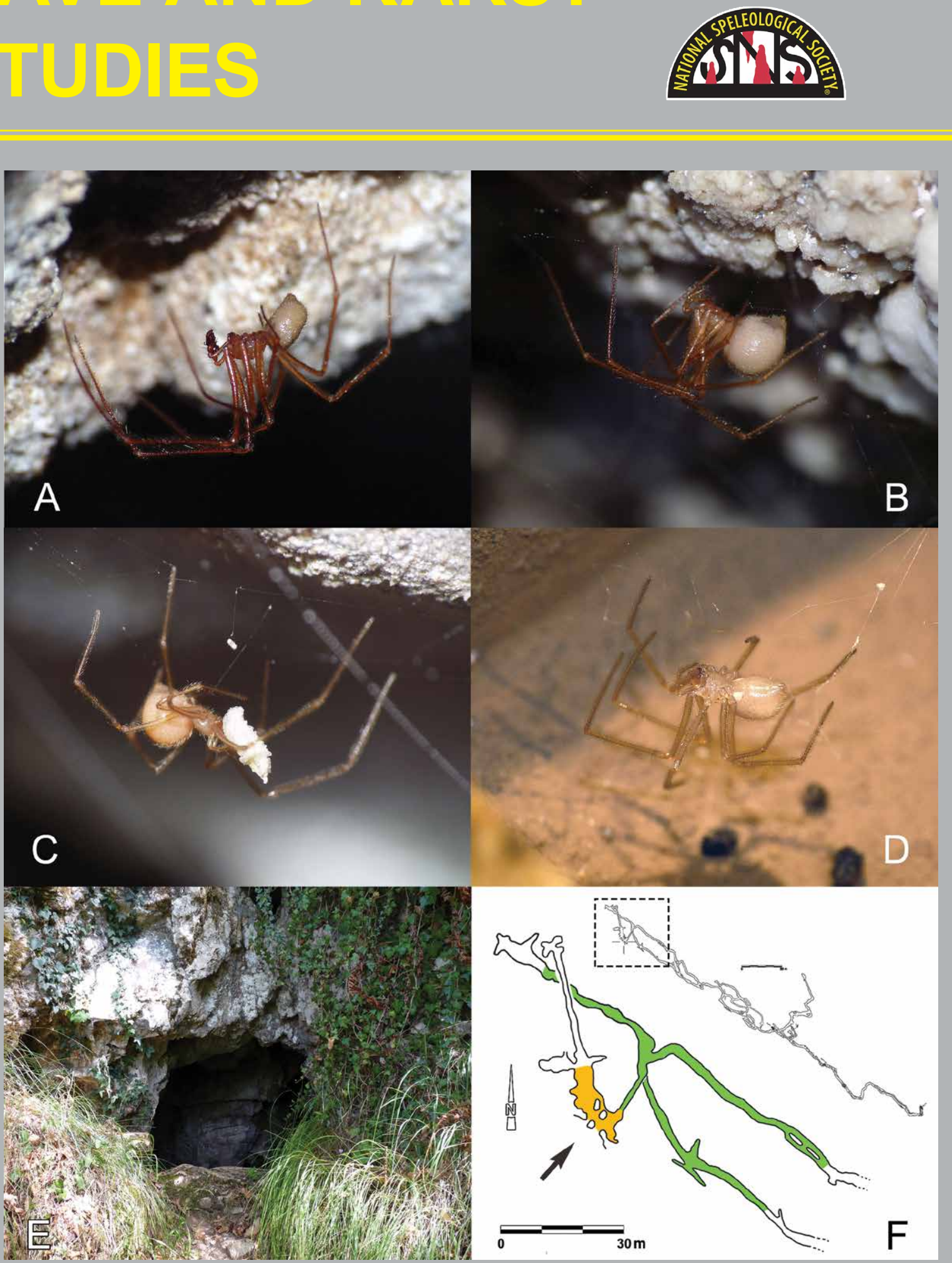

DEDICATED TO THE ADVANCEMIENT OF SCIENCE. EDUCATION, EXPLORATION, AND CONSERVATION 


\section{Published By \\ The National Speleological Society \\ http://caves.org/pub/journal \\ Office \\ 6001 Pulaski Pike NW \\ Huntsville, AL 35810 USA \\ Tel:256-852-1300 \\ nss@caves.org \\ Editor-in-Chief \\ Malcolm S. Field \\ National Center of Environmental \\ Assessment (8623P) \\ Office of Research and Development \\ U.S. Environmental Protection Agency \\ 1200 Pennsylvania Avenue NW \\ Washington, DC 20460-0001 \\ 703-347-8601 Voice 703-347-8692 Fax \\ field.malcolm@epa.gov \\ Production Editor \\ Scott A. Engel \\ Knoxville, TN \\ 225-281-3914 \\ saecaver@gmail.com}

The Journal of Cave and Karst Studies, ISSN 1090-6924, CPM Number \#40065056, is a multi-disciplinary, refereed journal published four times a year by the National Speleological Society The Journal is available by open access on its website, or check the website for current print subscription rates. Back issues are available from the NSS office.

POSTMASTER: send address changes to the National Speleological Society Office listed above.

The Journal of Cave and Karst Studies is covered by the following ISI Thomson Services Science Citation Index Expanded, ISI Alerting Services, and Current Contents/Physical, Chemical, and Earth Sciences.

Copyright (@ 2020

by the National Speleological Society, Inc.

\section{BOARD OF EDITORS}

\author{
Anthropology \\ George Crothers \\ University of Kentucky \\ Lexington, $\mathrm{KY}$ \\ george.crothers@utk.edu
}

\section{Conservation-Life Sciences \\ Julian J. Lewis \& Salisa L. Lewis \\ Lewis \& Associates, LLC. \\ Borden, IN \\ lewisbioconsult@aol.com}

\section{Earth Sciences}

Benjamin Schwartz

Texas State University

San Marcos, TX

bs37@txstate.edu

Leslie A. North

Western Kentucky University

Bowling Green, KY

leslie.north@wku.edu

Mario Parise

University Aldo Moro

Bari, Italy

mario.parise@uniba.it

Carol Wicks

Louisiana State University

Baton Rouge, LA

cwicks@lsu.edu

Exploration

Paul Burger

National Park Service

Eagle River, Alaska

paul_burger@nps.gov

\section{Microbiology}

Kathleen H. Lavoie

State University of New York

Plattsburgh, NY

lavoiekh@plattsburgh.edu

\section{Paleontology}

Greg McDonald

National Park Service

Fort Collins, CO

greg_mcdonald@nps.gov

\section{Social Sciences}

Joseph C. Douglas

Volunteer State Community College

Gallatin, TN

615-230-3241

joe.douglas@volstate.edu

Book Reviews

Arthur N. Palmer \& Margaret V Palmer State University of New York

Oneonta, NY

palmeran@oneonta.edu

Front cover: Habitus and type locality of Domitius culsu sp. nov. See Ballarin in this issue. 
Nataša Nikolić, Nikola Zarubica, Bojan Gavrilović, Dragana Predojević, Ivana Trbojević, Gordana Subakov Simić and Slađana Popović. Lampenflora and the entrance biofilm in two show caves: comparison of microbial community, environmental, and biofilm parameters. Journal of Cave and Karst Studies, v. 82, no. 2, p. 69-81. DOI:10.4311/2018EX0124

\title{
LAMPENFLORA AND THE ENTRANCE BIOFILM IN TWO SHOW CAVES: COMPARISON OF MICROBIAL COMMUNITY, ENVIRONMENTAL, AND BIOFILM PARAMETERS
}

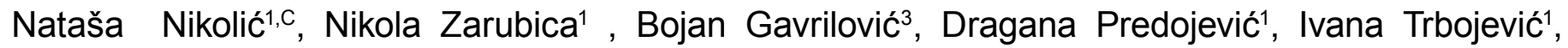 \\ Gordana Subakov Simić ${ }^{1}$, and Slađana Popović 2
}

\begin{abstract}
Phototrophic microorganisms from two caves in Serbia (Podpeć and Stopić) were examined. Samples were taken from the entrances where natural light was present, as well as from the inside caves near artificial light (lampenflora community). Cyanobacteria, Chlorophyta, Bacillariophyta and Xanthophyta were documented, with 51 taxa in total. The highest number of taxa recorded in the Cyanobacteria were coccoid cyanobacteria; Gleocapsa and Chroococcus were dominant. According to the redundancy analysis (RDA), Cyanobacteria were dominant at cave entrances while other groups (Chlorophyta, Bacillariophyta and Xanthophyta) were documented in lampenflora samples. Temperature, relative humidity, and light intensity were measured, as well as chlorophyll a concentrations and biofilm parameters (water, organic and inorganic matter content). Ecological parameters did not show significant variation, while light intensity depended on the position of sampling sites. RDA showed that the water content was higher in biofilm samples from cave entrances, while levels of inorganic matter were increased in lampenflora samples. The concentration of chlorophyll a did not show significant correlations with any of the measured ecological or biofilm parameters. Although the ecological parameters inside the cave did not show significant variation, they should be monitored because of the potential influence on the development of the lampenflora community that has a negative aesthetic impact on cave formations.
\end{abstract}

\section{Introduction}

Despite their extreme conditions, caves are unusual ecosystems inhabited by unique organisms. On the inside of caves, light intensity (LI) decreases as we go further away from the entrance, while the temperature (T) and air humidity show little or no variation, but the cave's entrance is under the influence of temperature and humidity from the outside environment (Hajdu, 1977; Vinogradova et al. 1998; Pedersen, 2000). In isolated and extreme environments, such as caves, specific organisms from different groups can be found (bacteria, cyanobacteria, algae, fungi, mosses, lichens, invertebrates, and vertebrates) (Mulec et al., 2008; Mulec and Kosi, 2009; Cerwik-Marcinkovska, 2013). Due to their natural beauty, caves are often open to the public, which can lead to the disturbance of the stable conditions in these habitats. The installation of artificial light in caves is the main reason for cave substrate colonization by phototrophic organisms. The lights change the values of the temperature and air humidity, which affects the rock surface the phototrophs' development (Mulec and Kosi, 2009). This phototrophic community is called lampenflora or lamp flora and includes many organisms, such as bacteria, cyanobacteria, algae, mosses, fungi and lichens (Dobat, 1998; Mazina and Severin, 2007). Lampenflora may include "r-selected species" and fast-growing species often capable of tolerating lower temperature $(T)$, relative humidity $(\mathrm{RH})$ and nutrient input (Aleya, 1991; Borderieet al., 2014). Biochemical deterioration (also known as biocorrosion) of the substratum is caused by the metabolic processes of the microorganisms (Macedo et al., 2009). During the respiration process, microorganisms release $\mathrm{CO}_{2}$, which when mixed with the surrounding water, produces the carbonic acid that causes the biodeterioration of cave structures (Aleya, 1991; Macedo et al., 2009; Borderie et al., 2014). According to Jurado et al. (2010) communities of these organisms can include potentially toxic or pathogenic microorganisms that represent a potential danger for animals and humans, and species whose physiology is still unknown.

The study of the diversity and growth control of lampenflora communities in tourist caves seems particularly important. In the Republic of Serbia, the pioneering study was performed by Popović et al. (2015a, b; 2016a, b, c; 2017a, b). Similar research endeavors in the region were conducted in the Republic of Slovenia (Klemenčić and Vrhovšek, 2005; Mulec and Kosi, 2008, 2009; Mulec et al., 2008, 2012) the Republic of Croatia (Ercegović 1925, 1932; Golubić, 1967) and the Republic of Macedonia (Tofilovska et al., 2014).

The aim of this study was to investigate the diversity of cyanobacteria and algae in two tourist caves, Podpeć and Stopić, in Serbia, and to compare the microbial communities from cave entrances with those deeper inside the caves

\footnotetext{
${ }^{1}$ University of Belgrade, Faculty of Biology, Studentski trg 16, 11000 Belgrade, Serbia

2 University of Belgrade, Scientific Institution, Institute of Chemistry, Technology and Metallurgy, National Institute, Department of Ecology and Technoeconomics, Njegoševa 12, 11000 Belgrade, Serbia

${ }^{3}$ Serbian Academy of Sciences and Arts, Geographical Institute "Jovan Cvijić", Department of Physical Geography, Đure Jakšića 9, 11000 Belgrade, Serbia

${ }^{c}$ Corresponding author: nikolic.natasa@outlook.com
} 
from typical lampenflora. Additionally, environmental parameters were measured. Moreover, primary production and biofilm parameters (water, organic and inorganic matter content) were measured and compared between entrance biofilms and lampenflora.

\section{Materials and Methods}

\section{Sampling Sites}

Podpeć Cave is located in Western Serbia, in the village of Potpeće, $186 \mathrm{~km}$ from Belgrade $\left(43^{\circ} 47^{\prime} 45.1^{\prime \prime} \mathrm{N}\right.$ $\left.19^{\circ} 56^{\prime} 00.8^{\prime \prime} \mathrm{E}\right)$. The cave entrance has a horseshoe shape $50 \mathrm{~m}$ height with a $22 \mathrm{~m}$ wide arch. The width at the base is $12 \mathrm{~m}$. This cave was formed by the Petnica River as it sunk in Drežnička Valley and flowed through $5 \mathrm{~km}$ long underground streams. According to Cvijić (1914a), limestone rocks in this area were formed in the Middle Trias and are characterized by whitish colors, cracked porosity, and a mosaic structure (Marković, 1957). The cave has two levels of passages, older - the Upper Cave, and younger - the Lower Cave. The portion of the cave that is developed for visitors, with paths and artificial light, is $555 \mathrm{~m}$ long.

Stopić Cave is located on the northeastern side of Zlatibor Mountain, $250 \mathrm{~km}$ from Belgrade $\left(43^{\circ} 42^{\prime} 12.0^{\prime \prime} \mathrm{N}\right.$ $\left.19^{\circ} 51^{\prime} 12.4^{\prime \prime E}\right)$. The cave entrance is located on the right side of the Prištavica River, 711 mabove sea level. It is $35 \mathrm{~m}$ wide and $18 \mathrm{~m}$ high.The explored part of the cave is $2000 \mathrm{~m}$ long and in some places the ceiling is $50 \mathrm{~m}$ high. The limestone rocks were formed in the Middle Trias and are over $100 \mathrm{~m}$ thick (Cvijić, 1914b). The unique characteristics of the cave are rimstone pools formed by deposited limestone and an underground waterfall called "The Source of Life" formed by Trnavski stream that flows through the cave (Lazarević, 2012).The portion of the cave developed for tourists is several hundred meters long, and $1658 \mathrm{~m}$ of the cave system has been explored, so far. Locations of Stopić and Podpeć caves are presented in Figure 1.

For algological analyses, five sampling sites in Podpeć Cave were chosen. One sampling site was at the entrance (P5) and four sampling sites were chosen inside the cave (P1, P2, P3,P4). Six sampling sites were chosen in Stopić Cave, three inside (S1, S2, S3) and three at the entrance to the cave (S4, S5, S6). Sampling sites of the two investigated caves are presented in Figures 2 and 3. The sampling sites are shown in Figures 4 and 5. Samples were collected in July 2016.

\section{Environmental Parameters}

Environmental parameters were measured in situ using the DMV 1300 Luxmeter (Vellemarn, Belgium) for Light Intensity, and Temperature humidity meter (Extech, USA) for those parameters. These parameters were measured five times for each site and the mean values were calculated.

\section{Biofilm Analyses}

The samples for measuring the biofilm content (water content (WC), organic matter (OM) and inorganic matter (IM),
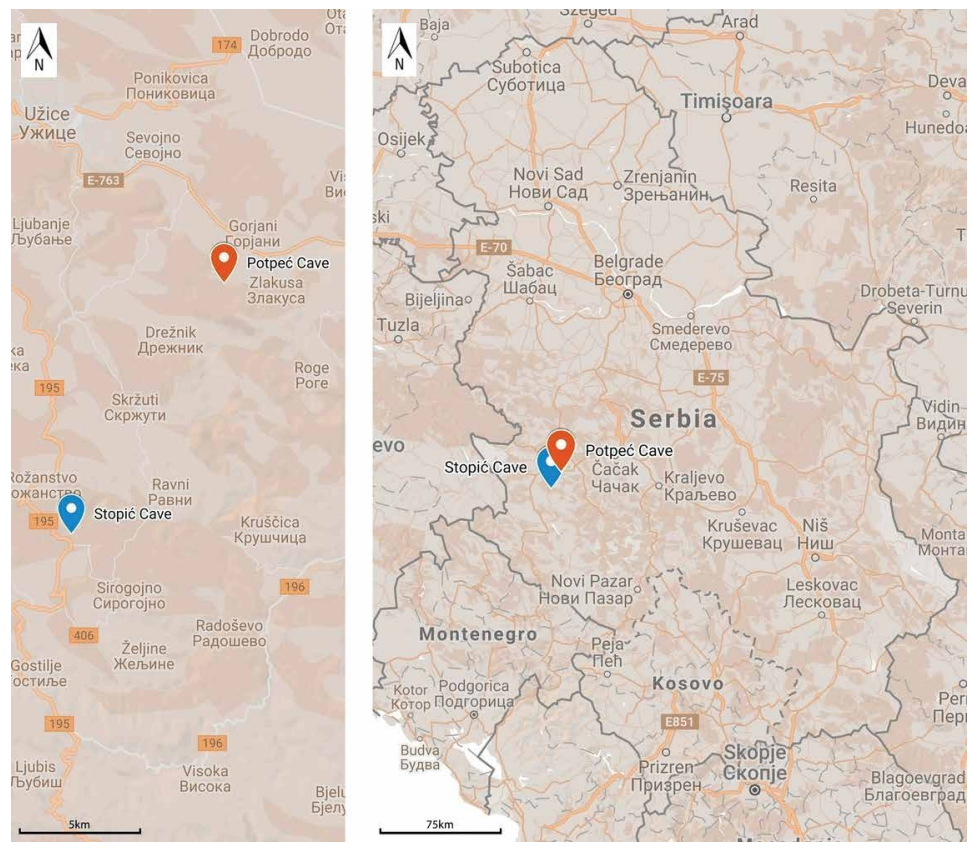

Figure 1. Maps of the two investigated caves: Stopić and Podpeć. Sources: Google Maps, http://www.clipart-library.com. and chlorophyll a $(\mathrm{Chl}$ a) extraction were scraped from stone substrata using a round metal moldcovering asurface area of $3.14 \mathrm{~cm}^{2}$.

The WC, OM and IM content was calculated as the difference between the biofilm weight before and after drying at $105^{\circ} \mathrm{C}$ and after ashing at $550^{\circ} \mathrm{C}$ (Popović et al., 2017a). The WC was measured as the difference between the fresh and dried weight. OM was calculated as the weight difference between the dried and the ashed biofilm, while IM content was equal to the weight of the remains after the biofilm was ashed. All three parameters were expressed in two ways, as a quantity per surface area $\left(\mathrm{mg} / \mathrm{cm}^{2}\right)$ and as a percentage of each constituent in a biofilm sample. The concentration of Chl a was determined by spectrophotometry using a formula described in Popović et al. (2015a) and expressed as $\mu \mathrm{g} / \mathrm{cm}^{2}$.

Qualitative analyses of algae were performed by using the non-destructive adhesive tape method (Urzi and de Leo, 2001) and by scraping the biofilm with a sterilized scalpel. The samples were fixed with a drop of glycerol and observed on a Zeiss Axio- Imager M1 light microscope with Axio Vision 4.8 software. 

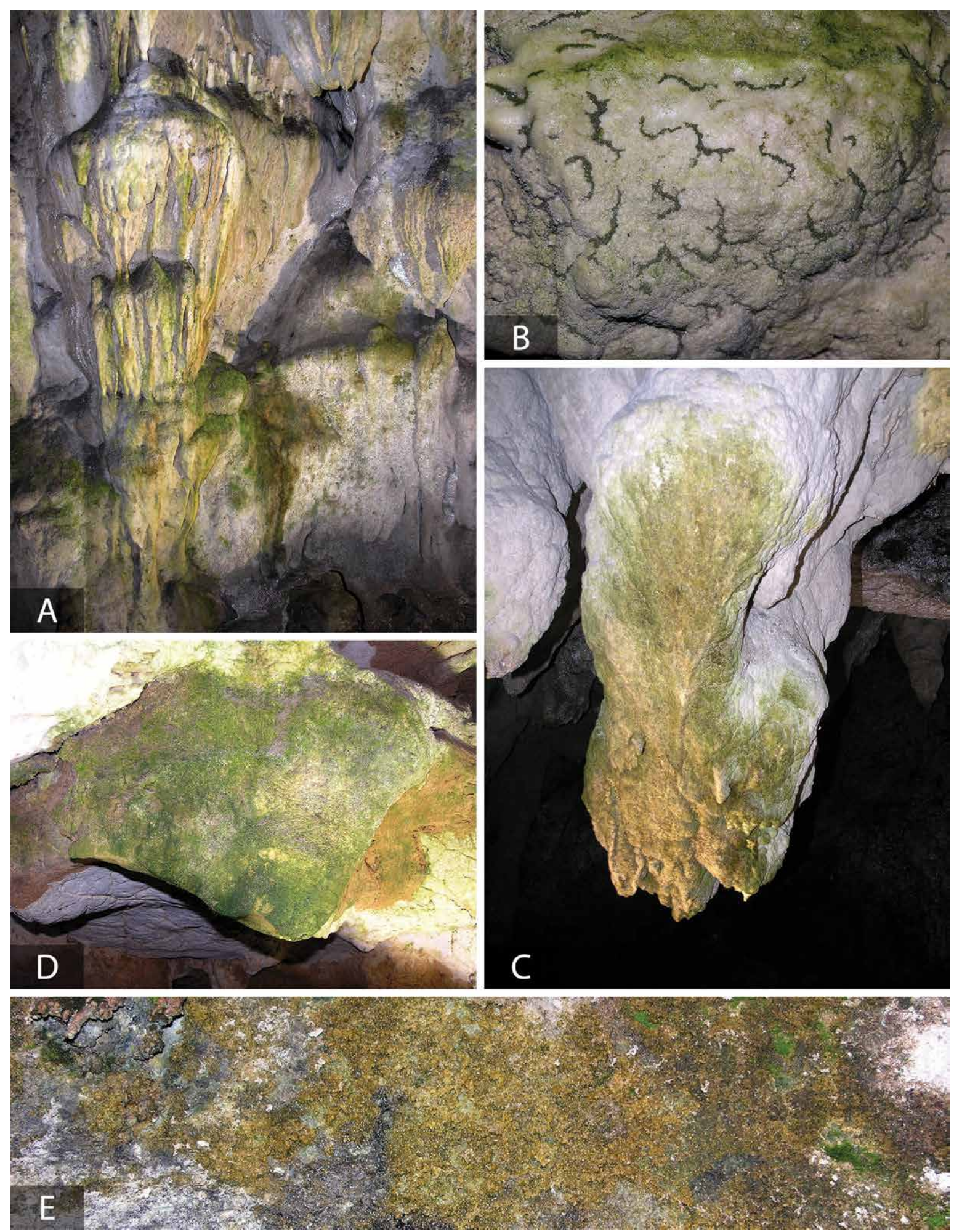

Figure 2. Podpeć cave, sampling sites: A-D - inside the cave: A - site P1; B - site P2; C - site P4; D - site P3; E entrance of the cave, site P5. ic groups were used instead of the individual genera and species that were identified. RDAwas performed to demonstrate the preference of each groupinone of two communities: lampenflora and at the cave entrances. The nominal variables, lampenflora and cave entrance, were used as explanatory variables. The WC and content of (OM) and (IM) in biofilms (expressed as percentages) were included as supplementary variables.

XLSTAT addition in Excel was used to calculatethe correlation between recorded physical parameters ( $T, R H, L I)$, $\mathrm{Chl} a$ and biofilm parameters (WC, OM and IM, expressed as $\mu \mathrm{g} / \mathrm{cm}^{2}$ ). 

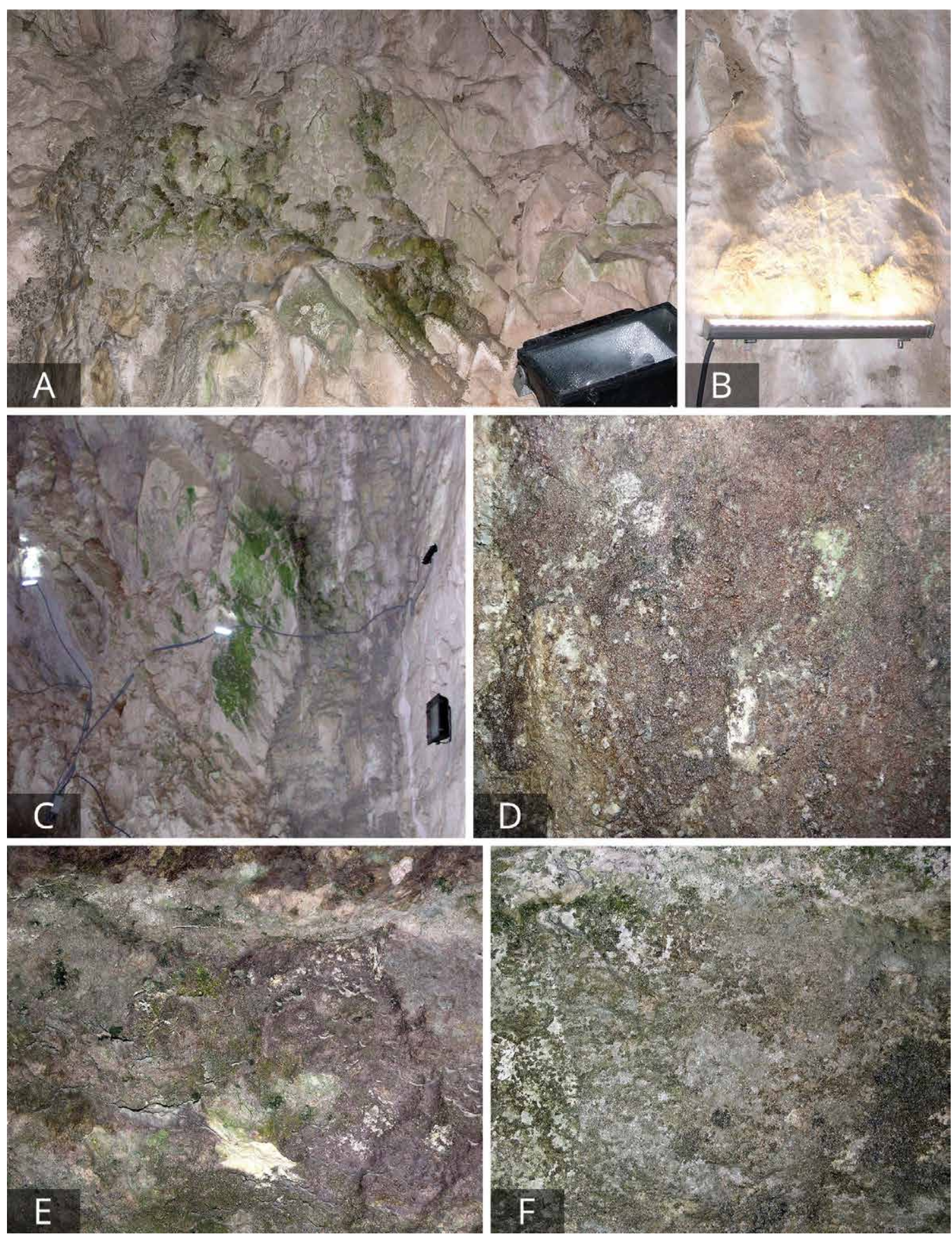

Figure 3. Stopić Cave, sampling sites: A-C - inside the cave: A - site S1; B - site S2; C - site S3; D-F - entrance of the cave: D - site S4; E - site S5; F - site S6.

P5 (85\%), while the lowest was at P1 (58\%). Between the sites inside Podpeć Cave, T varied up to $5{ }^{\circ} \mathrm{C}$, $\mathrm{RH}$ varied up to $12 \%$, while between the sites inside Stopić Cave, T varied up to $3.6^{\circ} \mathrm{C}$ while $\mathrm{RH}$ varied up to $19 \%$. Outside sampling points in Podpeć Cave had higher T and RH than inside the cave, while at the entrance of Stopić Cave, values of the T and $\mathrm{RH}$ were similar to those measured inside the cave. The lowest value of LI was 4 lux at sampling site S3 and the highest value was 3100 Lux at sampling site S2 in Stopić Cave. In Podpeć Cave, the highest value of LI was 840 Lux at point P4, while the lowest value of 265 Lux was at sampling site P2 .

\section{Results}

The ecological parameters measured in the Podpeć (P1, P2, $\mathrm{P} 3$ and $\mathrm{P} 4$ inside the cave, P5 at the entrance) and Stopić caves (S1, S2, S3 inside the cave, S4, S5, S6 at the entrance of the cave) are presented in Figure 6. For both caves, the ecological parameters ( $T$ and $\mathrm{RH})$ showed a certain degree of variation, but only $\mathrm{LI}$ values showed notable differences among sampling sites, as well as between caves. The highest temperature was measured at P5 $\left(22{ }^{\circ} \mathrm{C}\right)$, while the lowest was at P2 $\left(15.3{ }^{\circ} \mathrm{C}\right)$ in Podpeć Cave, while in Stopić Cave the highest temperature was at S2 $\left(19.9^{\circ} \mathrm{C}\right)$ and the lowest was at S3 $\left(16.3^{\circ} \mathrm{C}\right)$. RH varied from the lowest value of $56 \%$ at S2 to the highest value of $78 \%$ at sampling sites S5 and S6 in Stopić Cave. The highest value of relative humidity in Podpeć Cave was at the point 



Figure 4. Map of the Podpeć Cave, sampling sites; P1-P4 - sampling sites inside the cave, P5 - sampling site at the entrance. Source: Speleological atlas of Serbia(1998).

Biofilm parameters (WC, OM and IM) expressed as $\mathrm{mg} / \mathrm{cm}^{2}$ depended on the position of the sampling site (Fig.7a). In Podpeć Cave, the (WC) was lowest at sampling site P4 and highest at P5. The OM content was also highest at P5 and very low at P1 and P2. P2 was also characterized by the lowest content of IM, while the highest value for this parameter in this cave was at sampling sites P3 and P5. In Stopić Cave, WC was highest at the site positioned at the cave entrance (S6) and lowest at S1 and S2 (lampenflora samples). The OM content was the highest at S6 and lowest at sampling sites S2 and S3. The IM content had the lowest measured value at sampling site S1 and the highest at site S5.

Figure $7 \mathrm{~b}$ presents WC, OM and IM expressed in percentages for all biofilm samples. In Podpeć Cave, the highest WC percentage was found in the biofilms from sampling sites P2 and P5, while the lowest was found at sampling site P4. The highest percentage of OM was also recorded at P5 and the lowest at sampling site P1. On the other hand, IM had the highest value at sampling site P1, while the lowest was at P5 in Podpeć Cave. In Stopić Cave, the highest value of WC and IM was measured at sampling sites S6 and S3, respectively, while OM was highest at point S6. The lowest values of WC, OM and IM in Stopić Cave were found at sampling sites S2, S5 and S6, respectively.

The lowest concentration of $\mathrm{Chl}$ a expressed as $\mu \mathrm{g} / \mathrm{cm}^{2}$ was documented at sampling sites S3 and S1 in Stopić Cave and P2 in Podpeć Cave, while the highest values of Chl a were at P3 and S6 (Fig.7a).

Correlations between T, RH, LI, Chl a, WC, OM and IM were performedusing Pearson's coefficient (Table 1). It appears that $\mathrm{Chl}$ a does not show significant correlation, positive or negative, with any of the listed parameters. $\mathrm{T}$ and $\mathrm{RH}$ were significantly positively correlated with both WC and OM.

In total, 51 taxa were documented from the two caves (Table 2). The highest number of taxa belonged to Cyanobacteria (44) while the remaining taxa belonged to Bacillariophyta (4), Chlorophyta (2) and Xanthophyta (1). Considering the caves separately, 39 taxa were recorded in theCyanobacteria division in Stopić Cave and 22 taxa were found in 


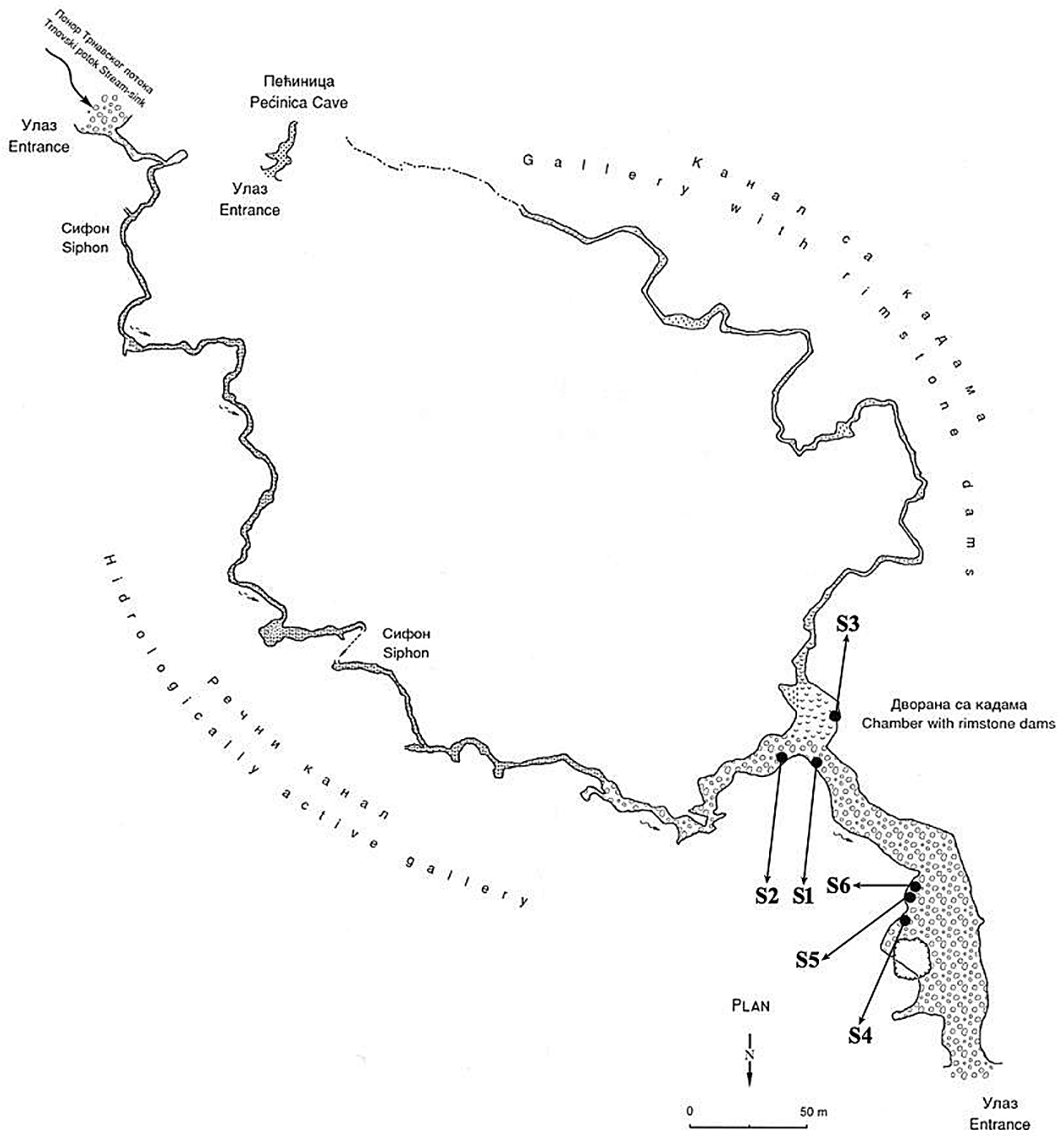

$\left.13\right|_{\begin{array}{l}\text { Cromuha пchuнa } \\ \text { Stopića Pećina }\end{array}}$

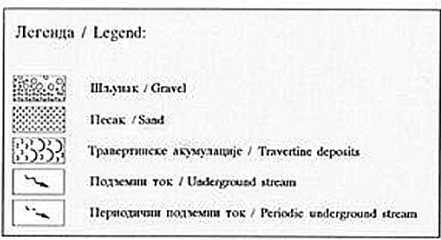

Figure 5. Map of Stopić Cave, sampling sites; S1-S3 - sampling sites inside of cave, S4-S6 - sampling sites at the entrance. Source: Speleological atlas of Serbia (1998).

Podpeć Cave. Stopić Cave was characterized by the presence of all four recorded Bacillariophyta taxa, while only one was documented in Podpeć Cave. Representatives of Chlorophyta and Xanthophyta were recorded in both caves. The most diverse cyanobacterial group was Chroococcales in both caves, where taxa of the genus Gleocapsa and Chroococcus dominate.The other two cyanobacterial groups, Oscillatoriales and Nostocales, were more numerous in Stopić Cave than in Podpeć Cave. Asterocapsa spp., Chrococcus ercegovicii, Leptolyngbia foveolarum, Leptolyngbia sp1, Leptolyngbia sp2, Nostoc punctiforme and an unknown taxon that belonged to Xanthophyta were present in all three sampling sites at the entrance of Stopić Cave, while inside the cave, the green algae cf. Chlorella sp. was dominant. Leptolyngbia foveolarum was the only cyanobacterial taxon found inside Stopić Cave. In Podpeć Cave, the green algae cf. Chlorella sp. and Humidophila sp. were found at the majority of the sampling sites inside the cave. At the cave entrance, Cyanobacteria were dominant. Gleocapsa atrata and Leptolyngbia foveolarum were the only taxa found inside Podpeć Cave. Two representatives of Chlorophyta have been recorded (Chlorella sp. and Trochiscia sp.) at every sampling site inside the caves (Table 2).

RDA analysis included nominal variables, lampenflora and communities at cave entrances, as the explanatory variables, and algal groups (Cyanobacteria-Chroococcales, Oscillatoriales and Nostocales, Chlorophyta, Bacillariophyta and Xanthophyta) as response data (Fig.8). The first RDA axis explained $58.8 \%$ of the variability in our data. Nominal variable, Lampenflora, was placed on the left side of the ordination diagram $(R=-0.9492)$ and the nominal variable, Cave entrance, on the right $(R=0.9492)$. The first axis represents the variation in microorganism assemblages between the two nominal variables. Bacillariophyta and Chlorophyta, as well as Xanthophyta, were dominant in lampenflora samples, while all three cyanobacterial groups were mostly documented in the biofilm samples taken at cave entrances. Supplementary variables show that the levels of IM in biofilms were higher in lampenflora samples, while the WC was higher in the biofilm samples at cave entrances (Fig.8). 


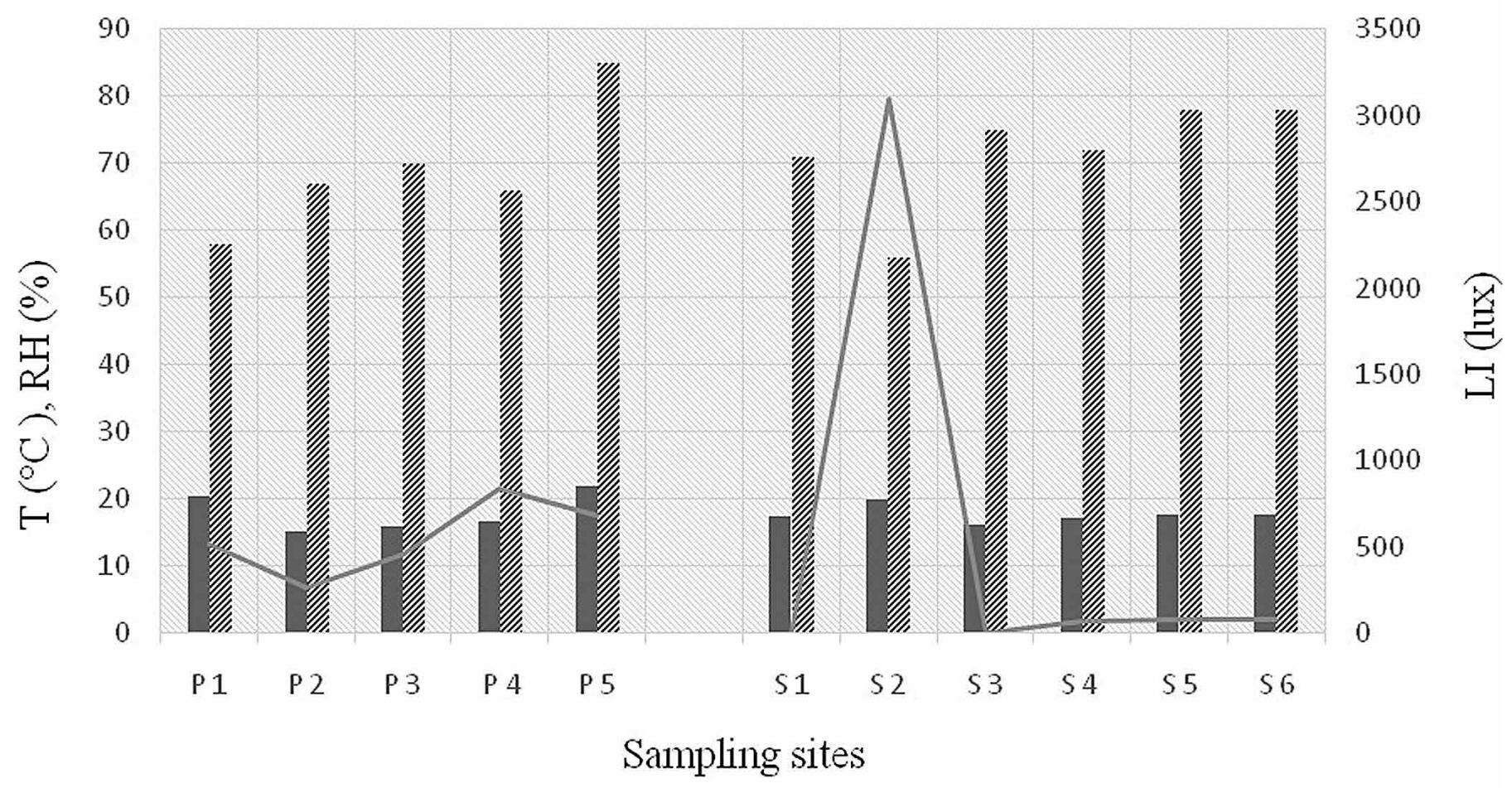

$\square\left({ }^{\circ} \mathrm{C}\right)$ พysssIs $\mathrm{RH}(\%) \quad \mathrm{LI}(\mathrm{lux})$

Figure 6. Values of ecological parameters: temperature $\left(\mathrm{T}\right.$ in $\left.{ }^{\circ} \mathrm{C}\right)$, relative humidity $(\mathrm{RH}$ in \%), light intesity (LI in Lux) at sampling sites from Podpeć (P1-P5) and Stopić (S1-S6) caves.

\section{Discussion}

At the entrance of caves, the influence of the outside climate ( $T$ fluctuation, $\mathrm{LI}$, water regime, and UV radiation) is evident, especially when T and RH are considered (Pentecost and Whitton, 2012). In Podpeć Cave, T and RH values differed at P5 compared to the rest of the sampling sites. At this site, located at the cave entrance, the highest value of T was measured, which coincides with the results by Popović et al. (2015a) and Cennamo et al. (2012). It should also be mentioned that the season in which the sampling was conducted also played a role. At the entrance of Stopić Cave, T and RH did not vary much from site to site and their values were similar to those measured inside the cave, probably due to the morphology of the cave and the big entrance zone which is influenced more by external conditions compared to Podpeć Cave. The LI at the entrance varied among sampling sites of both caves and depended on many factors, such as the size of the cave entrance, the presence/absence of vegetation, and exposure of the sampling sites. (Popović et al, 2017a).

According to Czerwik-Marcinkowska and Mrozińska (2011), T and RH are relatively stable inside caves; the temperature inside the caves of Central Europe ranges between $5^{\circ} \mathrm{C}$ and $8{ }^{\circ} \mathrm{C}$, while $\mathrm{RH}$ is between $85 \%$ and $95 \%$. However, other authors mentioned (Smith and Olson, 2007; Mulec and Kosi, 2009) that the introduction and installation of artificial light (especially warm light) and the presence of cave tourists, can have a negative impact on the microclimate and can influence changes in T and $\mathrm{RH}$. According to the information provided by guides in caves, the T in Stopić Cave vary from $9.5^{\circ} \mathrm{C}$ to $18^{\circ} \mathrm{C}$ and the lowest $\mathrm{RH}$ measured was $87 \%$ and which becomes higher depending on the season. In Podpeć Cave, T values were between $9{ }^{\circ} \mathrm{C}$ and $10.2^{\circ} \mathrm{C}$, and had $\mathrm{RH}$ values of $94 \%$ and higher.

Our samples were collected in the summer; however, in both caves, the measured $\mathrm{T}$ was higher, while $\mathrm{RH}$ was lower, due to the proximity of the sampling sites to artificial light sources, especially in Podpeć Cave. The type of lamps used differs between the caves: at the time of sampling, Podpeć Cave had lamps that emitted warmer light (these lamps have been changed since) compared to those in Stopić Cave, where LED lights had been installed. Cigna and Burri (2000) state that unsuitable lamps can lead to changes in environmental parameters, (e.g., Castellana Caves, South Italy where $\mathrm{T}$ increased from $15^{\circ} \mathrm{C}$ to $25^{\circ} \mathrm{C}$ while $\mathrm{RH}$ decreased from $95 \%$ to $100 \%$ to $55 \%$ to $60 \%$ near the light source). It is interesting to note that point S2 was found to have lower RH despite the presence of LED lamps, probably because the sampling point is very close to the light (very high LI was measured compared to other sampling sites). As seen from Table 1, increases in T and $\mathrm{RH}$ lead to increases in WC and OM (a significant positive correlation was observed) and higher values of WC and OM mean that better developed biofilms are present. 
Many groups of microorganisms can grow in the extreme oligotrophic conditions of cave environments (Czer-
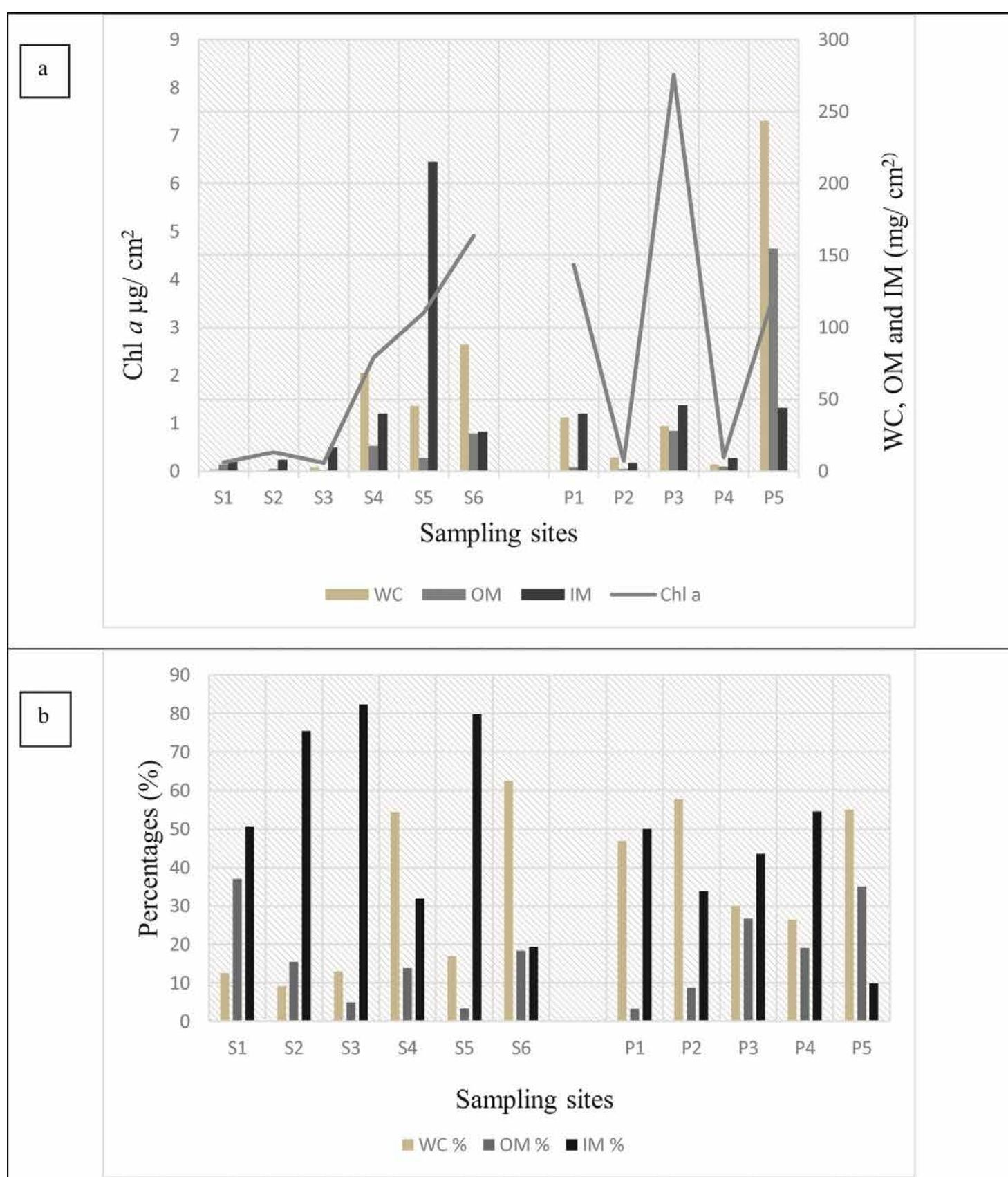

Figure 7. A - The concentration of chlorophyll a ( $\mathrm{Chl}$ a) expressed as $\mu \mathrm{g} / \mathrm{cm}^{2}$, water content (WC) and organic/ inorganic matter (OM/IM) expressed as $\mathrm{mg} / \mathrm{cm}^{2}$ from Podpeć (P1-P5) and Stopić (S1-S6) caves. B - Water content (WC), organic and inorganic matter (OM/IM) presented as percentages from Stopić (S1-S6) and Podpeć (P1-P5) caves.

marily on light, but also on $\mathrm{T}$ and $\mathrm{RH}$; all are considered the most important factors for their growth (Martinčič et al., 1981; Chang and Chang-Schneider, 1991). The microbial assemblage at the cave entrance and in lampenflora samples usually differs as a result of living in two different zones, one characterized by the presence of artificial light and nearly stable conditions, and the other influenced by the outside climate, daylight and factors that are more variable.

Differences in the diversity and assemblages of aerophytic cyanobacteria and algae in this study are obvious when samples from the cave entrance and lampenflora are compared. The diversity of phototrophic microorganisms was higher at cave entrances, where Cyanobacteria were dominant, and lower inside the caves. Moreover, in Figure 8, consid- 
Table 1. Correlations between T, RH, LI, ChI, WC, OM and IM using Pearson coefficient.

\begin{tabular}{cccccccc}
\hline Variables & $\mathbf{T}$ & $\mathbf{R H}$ & $\mathbf{L I}$ & $\mathbf{C h l} a$ & $\mathbf{W C}$ & $\mathbf{O M}$ & IM \\
\hline T & $\mathbf{1}$ & 0.008 & 0.423 & 0.125 & $\mathbf{0 . 6 3 5}$ & $\mathbf{0 . 6 0 7}$ & 0.067 \\
$\mathrm{RH}$ & 0.008 & $\mathbf{1}$ & -0.589 & 0.230 & $\mathbf{0 . 6 6 4}$ & $\mathbf{0 . 6 2 9}$ & 0.362 \\
$\mathrm{LI}$ & 0.423 & -0.589 & $\mathbf{1}$ & -0.198 & -0.112 & -0.016 & -0.235 \\
Chl a & 0.125 & 0.230 & -0.198 & $\mathbf{1}$ & 0.376 & 0.318 & 0.313 \\
WC & $\mathbf{0 . 6 3 5}$ & $\mathbf{0 . 6 6 4}$ & -0.112 & 0.376 & $\mathbf{1}$ & $\mathbf{0 . 9 5 6}$ & 0.153 \\
OM & $\mathbf{0 . 6 0 7}$ & $\mathbf{0 . 6 2 9}$ & -0.016 & 0.318 & $\mathbf{0 . 9 5 6}$ & $\mathbf{1}$ & 0.047 \\
IM & 0.067 & 0.362 & -0.235 & 0.313 & 0.153 & 0.047 & $\mathbf{1}$ \\
\hline
\end{tabular}

Note: Values in bold are different from 0 with a significance level alpha $=0.05$. ering the number of recorded taxa, Cyanobacteria were dominant at the cave entrances compared to algal groups. It should be noted that besides different environmental parameters, presence of seeping water

and cave morphology, many microclimatic parameters can play a role. Accordingly, we cannot be certain which factors contribute to the much higher diversity in Stopić Cave. In the lampenflora samples collected inside the caves, diversity was low, but two genera of green algae (Chlorella sp., Trohiscia sp.) were quite abundant and the green algae cf. Chlorella sp. was always found in biofilms. In tourist caves near artificial light, a lower diversity of cyanobacteria and algae is commonly observed near artificial lights when compared to cave entrances, green algae often being the first colonizers of stone substrata (Mulec, 2008) and dominant components (Mulec and Kosi, 2008, Czerwik-Marcinkowska et al., 2015, and Meyer et al., 2017). Frequently, these green algae assemblages include fast growing and r-selective species (Albertano, 2012; Borderie et al., 2014, Czerwik-Marcinkowska et al., 2015) such as representatives of the genus Chlorella. This algae is reported in many caves worldwide and is considered to be a big problem for cave conservators. The stable microclimate inside the cave and suitable conditions under artificial lighting compared to the fast changing conditions at the entrance, as well as the absence of other extreme conditions, can promote the development of green algae and diatoms, since these groups prefer a more stable environment for their growth (Mulec, 2008; Borderie et al., 2014). Dripping water with suspended nutrients can also have a positive effect on algal growth, especially on the representatives of Bacillariophyta (Vinogradova et al., 2009; Piano et al., 2015). Recorded Bacillariophyta taxa in this study are considered a typical cosmopolitan and most frequent genera in caves (Czerwik-Marcinkovska and Mrozińska, 2011; Falasco et al., 2014). Inside Podpeć Cave, only Humidophila sp. was registered, a genus that is distributed globally and most commonly on the wet limestone walls in caves (Lowe et al., 2014, 2017). Even though we did not record seeping water at sampling sites at the time of sampling, it does not mean that seeping water is not present during certain periods of the year. There are also cases in which cyanobacteria prevail in lampenflora communities, but according to Mulec et al. (2008), it can happen in biofilms that have been growing undisturbed for some time. On the other hand, cyanobacteria are frequently dominant in the biofilms from cave entrances, since they are capable of enduring more extreme conditions than green algae and diatoms (Pentecost and Whiton, 2012).

Primary production at all sampling sites was assessed by measuring the $\mathrm{Chl}$ a concentration. Chl a concentration is usually correlated with the degree of biofilm development (Popović et al., 2015a; 2017a). In Stopić Cave, the highest concentration of this parameter was determined at sampling site S6, which was characterized by a thick biofilm with higher WC and OM. The correlation of $\mathrm{Chl} a$ with these two parameters in general had slightly positive values, but were not significant.

Water is the most significant factor influencing the development and growth of the phototrophic community on surfaces exposed to air (Pentecost and Whitton, 2012). Moisture originates from different sources: precipitation, humidity, or groundwater seepage, and its level can be highly variable, so higher $\mathrm{RH}$ can contribute to better developed phototrophs reflected through higher WC and OM (Table 1). Well -hydrated biofilms contained more viable and active cells than the ones that were water deficient or temporarily dry, which is probably the reason why Chl a was usually higher in such samples. The rest of the sampling sites at Stopić Cave, especially the sites near artificial light, had lower Chl $a$ and OM concentrations, as expected, because the lampenflora were poorly developed in this cave and existing biofilms represented the remains of the old lampenflora that had developed during the previous year and before the cave reconstruction and the installation of new and better artificial LED lighting. In Podpeć Cave the concentration of Chl a varied and had high values at the sampling site at the cave entrance, but also at the two sampling sites near artificial light (sites P1 and P3) where lampenflora were quite well developed (Fig. 2). Compared to Stopić Cave, lampenflora in Podpeć Cave, especially at P1 and P3, were more developed and characterized with biofilm where, among cyanobacteria, algae and many organic and inorganic particles, mosses were also present (Amblystegium serpens was dominant and Tortella tortuosa was recorded sporadically).

Biofilms from cave entrances and from the internal cave environment were also different in terms of WC, OM and IM. High WC in biofilm samples from cave entrances, which is especially evident from sampling site P5 (Fig. 8), was the 
Table 2. Cyanobacterial and algal taxa from Podpeć (P1- P8) and Stopić (S1- S6) caves.

\begin{tabular}{|c|c|c|c|c|c|c|c|c|c|c|c|}
\hline \multirow[b]{3}{*}{ Taxa/Samples } & \multicolumn{6}{|c|}{ Stopić Cave } & \multicolumn{5}{|c|}{ Podpeć Cave } \\
\hline & \multicolumn{3}{|c|}{$\begin{array}{c}\text { Inside the } \\
\text { Cave }\end{array}$} & \multicolumn{3}{|c|}{$\begin{array}{c}\text { Cave } \\
\text { Entrance }\end{array}$} & \multicolumn{4}{|c|}{$\begin{array}{c}\text { Inside the } \\
\text { Cave }\end{array}$} & $\begin{array}{c}\text { Cave } \\
\text { Entrance }\end{array}$ \\
\hline & s1 & S2 & S3 & S4 & S5 & s6 & P1 & P2 & P3 & $\mathbf{P} 5$ & P8 \\
\hline
\end{tabular}

Cyanobacteria

Chroococcales

Aphanocapsa cf. planctonica (G.M.Smith) Komárek \& Anagnostidis

Aphanocapsa muscicola (Meneghini) Wille

Aphanocapsa rivularis (Carmichael) Rabenhorst

Aphanocapsa sp. Nägeli

Aphanothece caldariorum P.G. Richter

Aphanothece saxicola Nägeli

Asterocapsa spp. H.-J.Chu

Chondrocystis dermochroa (Nägeli) Komárek \& Anagnostidis

Chroococcus cf. spelaeus Ercegovic

Chroococcus ercegovicii Komárek \& Anagnostidis

Chroococcus pallidus Nägeli

Chroococcus turgidus (Kützing) Nägeli

Chroococcus varius A. Braun

Chroococcus sp. Nägeli

Cyanothece aeruginosa (Nägeli) Komárek

Eucapsis sp. F.E. Clements \& H.L. Shantz

Gloeocapsa alpina Nägeli

Gloeocapsa atrata Kützing

Gloeocapsa cf. granosa (Berkeley) Kützing

Gloeocapsa compacta Kützing

Gloeocapsa nigrescens Nägeli

Gloeocapsa punctate Nägeli

Gloeocapsa violacea Kützing

Gloeocapsa sp. Kützing

Gloeothece cf. incerta Skuja

Oscillatoriales

Leptolyngbya foveolarum (Gomont) Anagnostidis \& Komárek

Leptolyngbya henningsi(Lemmermann) Anagnostidis

Leptolyngbya valderiana (Gomont) Anagnostidis \& Komárek

Leptolyngbya sp.1 Anagnostidis \& Komárek

Leptolyngbya sp. Anagnostidis \& Komárek

Phormidium cf. ambiguum Gomont

Phormidium corium Gomont ex Gomont

Phormidium sp. Kützing ex Gomont

Porphyrosiphon fuscus Gomont ex Frémy

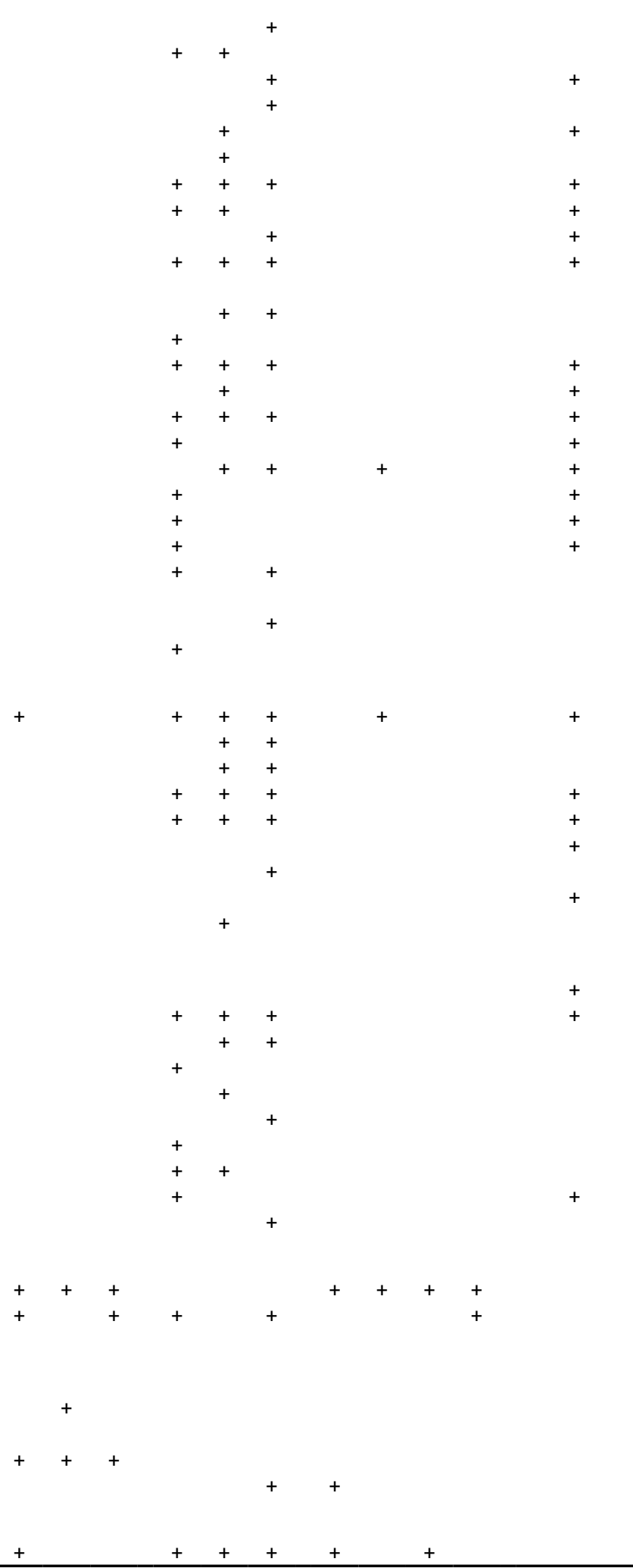

Nostocales

Nostoc commune Vaucher ex Bornet \& Flahault

Nostoc punctiforme Hariot

Nostoc sp. Paracelsus

Scytonema cf. bruneum Schmidle

Scytonema drilosiphon Elenkin \& V.I. Polyansky

Scytonema hofmannii C. Agardh ex Bornet \& Flahault

Scytonema mirabile Wolle

Scytonema subtile K. Möbius

Scytonema sp. Agardh ex Bornet et Flahault

Tolypothrix tenuis Kützing ex Bornet \& Flahault

Chlorophyta

Chlorella sp. Beyerinck

Trochiscia sp. Kützing

Bacillariophyta

Hantzschia sp. Grunow

Humidophila sp. (Lange-Bertalot \& Werum) R.L. Lowe, Kociolek,

J.R.Johansen, Van de Vijver, Lange-Bertalot \& Kopalová

Orthoseira spp. Thwaites

Pinnularia sp. Ehrenberg

Xanthophyta

Xanthophyta unknown 


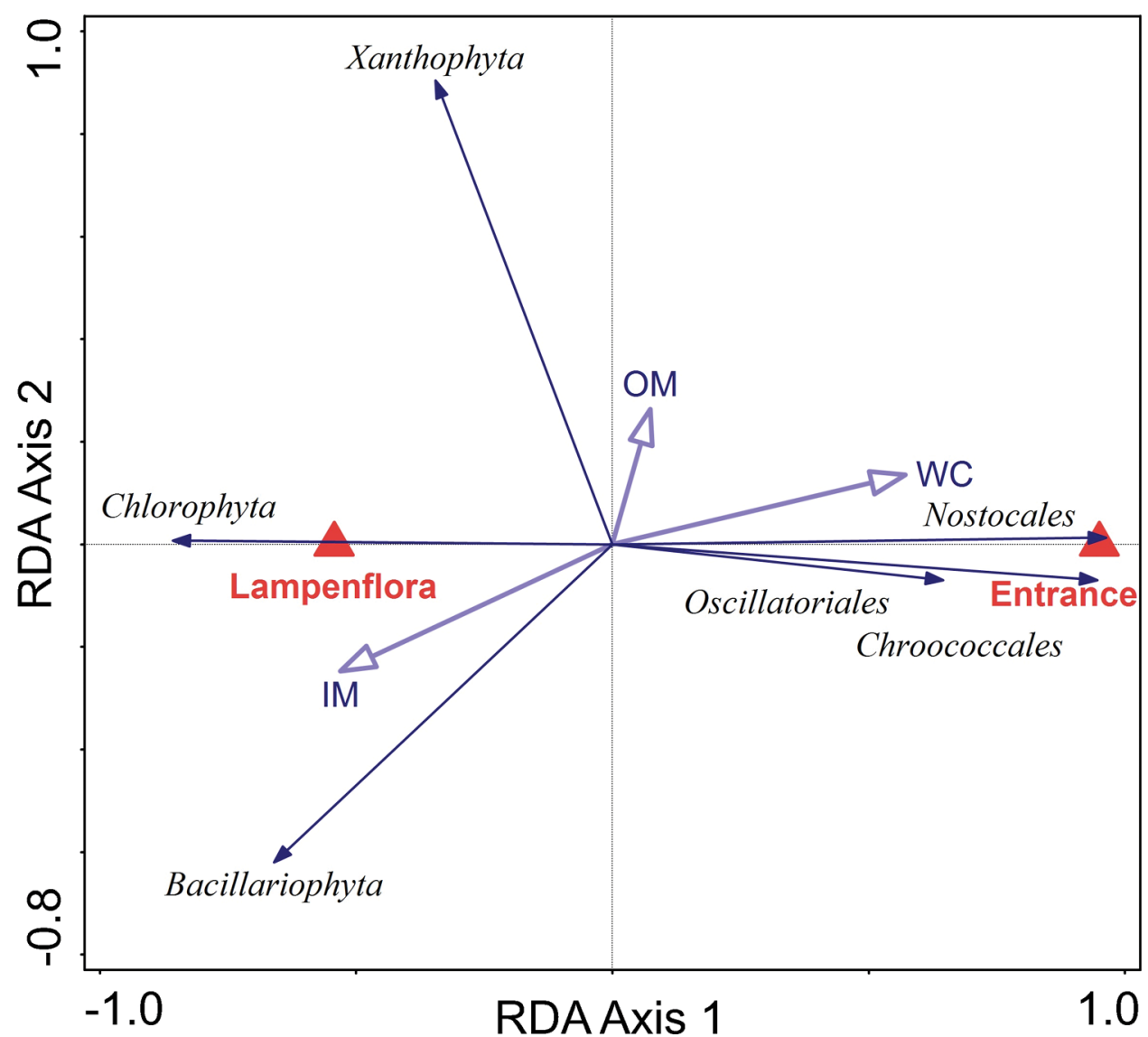

Figure 8. RDA analysis showing the relationship between explanatory variable, lampenflora and communities at cave entrances, and responce variables (Cyanobacteria-Chroococcales, Oscillatoriales and Nostocales), Chlorophyta, Bacillariophyta and Xanthophyta). Included supplemenatary variables are: content of organic (OM) and inorganic matter (IM) and water content (WC).

result of the presence and dominance of cyanobacteria. Cyanobacterial extracellular polysaccharides (EPS) play an important role in stress tolerance (Chug and Mathur, 2013) and thanks to these polysaccharides, cyanobacteria are not so vulnerable to variations in climatic conditions. One of their main roles is that they can retain water and enable cyanobacteria to better survive drought conditions, facilitating survival in an aerophytic habitat (Pentecost and Whitton, 2012; Chug and Mathur, 2013; Li et al., 2013).IM was higher in almost all lampenflora samples.

Lampenflora often cause the deterioration of stone substrata and cave formations. Lampenflora were especially very well-developed in Podpeć Cave, and at some sites, deteriorated parts of the stone base were mixed with biofilm components, which influenced IM content. The process of substrate deterioration in cave environments is of special concern, especially in caves with numerous attractive speleothems. The metabolic activities of microorganisms not only leads to undesired change in cave formations, but they can also disturb the habits of native organisms (Piano et al., 2015). The removal of lampenflora is achieved through various mechanical or chemical treatments. However, all such actions should be practicable and with minimal impact to the cave environment and organisms (Trih et al., 2018).

\section{Conclusions}

Cyanobacteria and algae were examined from biofilm samples taken from the Podpeć and Stopić caves. Cyanobacteria, Chlorophyta, Bacillariophyta and Xanthophyta were recorded, with the highest diversity found in the coccoid cyanobacteria. Cyanobacteria were dominant at cave entrances, while green algae were prominent elements of caves' lampenflora. Cf. Chlorella sp. was recorded in every lampenflora sample. Ecological parameters did not vary significantly, except for the LI that was dependent on the different aspects of cave entrances (i.e., their size) and sampling sites. Biofilm parameters (water content, content of organic and inorganic matter) varied greatly between samples collected near entrances and inside the caves. Chlorophyll a did not show clear correlations with any of the other measured parameters. The metabolic activity of green algae, which usually compromise part of the lampenflora, causes biodeterioration of the stone substratum and can lead to the irreversible damage of cave structures. Further investigations are necessary, since the knowledge on cave biofilms on the Balkan Peninsula is limited.

\section{Acknowledgements}

This research was supported by the Ministry of Science and Technological Development, Republic of Serbia, Projects No 176020 and No. 176018 and the Ministry of Agriculture and Environmental Protection of the Republic of Serbia. The authors thank reviewers for helpful comments and suggestions that significantly improved the manuscript, Prof.Dr. Marko Sabovljević for moss identification, caves management and guides for their assistance throughout all aspects of our study and Branislav Nikolić for useful comments and technical support during preparation of the manuscript. 


\section{References}

Albertano, P., 2012, Cyanobacterial biofilms in monuments and caves, in: Whitton B.A., ed., Ecology of Cyanobacteria II: Their Diversity in Space and Time: London, Springer, p. 317-343. https://doi.org/10.1007/978-94-007-3855-3_11.

Aleya, L., 1991, The concept of ecological succession applied to an eutrophic lake through the seasonal coupling of diversity index and several parameters: Archiv für Hydrobiologie, v. 120, p. 327-343.

Borderie, F., Tête, N., Cailhol, D., Alaoui-Sehmer, L., Bousta, F., Rieffel, D., Aleya, L., and Alaoui-Sossé, B., 2014, Factors driving epilithic algal colonization in show caves and new insights into combating biofilm development with UV-C treatments: Science of the Total Environment, $v$. 48, p. 43-52. https://doi.org/10.1016/j.scitotenv.2014.03.043

Cennamo, P., Marzano, C., Ciniglia, C., Pinto, G., Cappelletti, P., Caputo, P., and Pollio, A., 2012, A survey of the algal flora of anthropogenic caves of Campi Flegrei (Naples, Italy) archeological district: Journal of Cave and Karst Studies, v. 74 no. 3, p. 243-250. https://doi. org/10.4311/2011JCKS0194.

Chang, T.P., and Chang-Schneider, H., 1991, Algen in vier süddeutschen Höhlen(Algae in four southern German caves): Berichte der Bayer Bot Gesell, no. 62, p. 221-229. https://doi.org/10.1007/978-3-662-13231-9_14.

Chug, R., and Mathur, S., 2013, Extracellular polymeric substances from Cyanobacteria: Characteristics, isolation and biotechnological applications - A review: International Journal of Advances in Engineering, Science and Technology (IJAEST), v.3, no.2, p. 49-53. ISSN : 2249-913X

Cigna, A.A., and Burri, E., 2000, Development, management and economy of show caves: International Journal of Speleology, v. 29 , p. 1-27. https://doi.org/10.5038/1827-806X.29.1.1.

Cvijić, J., ed., 1914a, Pećina u Potpeći (promatranja iz 1913.) Cave in Potpec (observation from 1913.): Glasnik Srpskog geografskog društva, sv. 3-4, Beograd.

Cvijić, J., ed., 1914b, Stopića pećina u Rožanstvu i ponor u Trnavi (Stopić Cave in village Rožanstvo and abyss in Trnava): Glasnik Srpskog geografskog društva, sv. 3 i 4 , Beograd.

Czerwik-Marcinkowska, J., and Mrozińska, T., 2011, Algae and cyanobacteria in caves of the Polish jura: Polish Botanical Journal, v. 56, no. 2, p. 203-243.

Czerwik-Marcinkowska, J., 2013, Observations on aerophytic cyanobacteria and algae from ten caves in the Ojców National Park: Acta Agrobotanica, v. 66, no. 1, p. 39-52. https://doi.org/10.5586/aa.2013.005.

Czerwik-Marcinkowska, J., Wojciechowska, A., and Massalski, A., 2015, Biodiversity of limestone caves: aggregations of aerophytic algae and cyanobacteria in relation to site factors: Polish Journal of Ecology, v. 63, p. 481-499.

Dobat, K., 1998, Flore de la lumiére artificiélle (lampenflora-maladieverte) [Flora of artificial light (lampenflora - green desease)], in Juberthie, C., and Decu, V., eds., Encyclopaedia Biospeleologica, Tome 2, Société de Biospéologie: Moulis-Bucarest, p. 1325-1335.

Djurović, P., ed., 1998, Speleoloski atlas Srbije (Speleological atlas of Serbia): Serbian Academy of Science and Art, Belgrade. 290p.

Ercegović, A., 1925, La végétation des lithophytes sur les calcaires et les dolomites en Croatie (The lithophyte vegetations on limestones and dolomites in Croatia): Acta Bot Croat, v. 1, p. 64-114.

Ercegović, A., 1932, Études écologiques et sociologiques des Cyanophycées lithophytes de la côteYougoslave de l'Adriatique (Ecological and sociological studies of lithophytes cyanophyceae on the Yugoslavian Adriatic coast): Bulletin of the International Academy of Yugoslavia, Science Beaux Arts v. 26, p. 33-56.

Ettl, H., 1978, Xanthophyceae. 1. Teil. in: Ettl, H., Gerloff, J., and Heynig, H., eds., Süßwasserflora von Mitteleuropa (Freshwater flora from Central Europe), 3: Gustav Fischer Verlag, Jena.

Ettl, H., and Gärtner, G., 1988, Chlorophyta II, Tetrasporales, Chlorococcales, Gloeodendrales. in: Ettl, H., Gerloff, J., Heynig, H., and Mollenhauer, D. eds., Süßwasserflora von Mitteleuropa (Freshwater flora from Central Europe), 10: Gustav Fischer Verlag, Stuttgart, New York.

Falasco, E., Ector, L., Isaia, M., Wetzel, C., E., Hoffman, L., and Bona, F., 2014, Diatom flora in subterranean ecosystems: a review: International Journal of Speleology, v. 43, n.3, p. 231-251. https://doi.org/10.5038/1827-806X.43.3.1.

Golubić, S., 1967, Algen vegetation der Felsen. Eine Öko-logische Algen studien im Dinarischen Karstgebiet (Algae vegetation of the rocks. An ecological algae study in the Dinaric karst area), in: Elster, H.J., and Ohle, W., eds, Die Biennenge wässer Schweitzerbart'sche Verlagsbuchhandlung ,Stuttgart, v. 22, p. 1-183.

Hajdu, L., 1977, The flora of Hungarian caves, Karsztés Barlang, Special Issue, Budapest.

Hofmann, G., Werum, M., and Lange-Bertalot, H., 2013, Diatomeen im Süßwasser-Benthos von Mitteleuropa. Bestimmungs flora Kieselalgenfür die ökologische Praxis (Freshwater diatoms - benthos from Central Europe. Determination diatoms flora for ecological practice): Königstein, Koeltz Scientific Books. 908 p.

Jimenez, S.C., 2012, Microbiological and environmental issues in caves: World Journal of Microbiology and Biotechnology, v. 28 , p. $2453-2464$. https://doi.org/10.1007/s11274-012-1070-x.

John, D.M., Whitton, B.A., and Brook, A.J., eds., 2003, The Freshwater Algal Flora of the British Isles: An Identification Guide to Freshwater and Terrestrial Algae: UK, Cambridge University Press. 702 p.

Jurado, V., Laiz, L., Rodriguez-Nava, V., Boiron, P., Hermosin, B., Sanchez-Moral, S., and Saiz-Jimenez, C., 2010, Pathogenic and opportunistic microorganisms in caves: International Journal of Speleology, v. 39, p. 15-24. https://doi.org/10.5038/1827-806X.39.1.2.

Klemenćič, A.K., and Vrhovšek, D., 2005, Algal flora of Krška Jama Cave, Slovenia: Acta Musei Nationalis Pragae, Series B, Historia Naturalis, v. 61 , no. $1-2$, p. $77-80$.

Komárek, J., and Fott, B., 1983, Chlorophyceae (Grünalgen). Ordnung: Chlorococcales. Das Phytoplankton děs Süßwassers, Systematik und Biologie (Freshwater phytoplankton, systematics and biology), in Elster, H.J., and Ohle, W., eds., Die Binnengewässer XVI, 7 (1): Stuttgart, Germany, Schweizerbart'scheVerlagsbuchhandlung, 1044 p.

Komárek, J., and Anagnostidis, K., 1998, Cyanoprokaryota 1. Teil/1st Part: Chroococcales, in Ettl, H., Gärtner, G., Heynig, H., and Mollenhauer, D., eds., Süßwasserflora von Mitteleuropa (Freshwater Flora From Central Europe) 19/1: Jena-Stuttgart-Lübeck-Ulm, Gustav Fischer, 548 p.

Komárek, J., and Anagnostidis, K., 2005, Cyanoprokaryota 2. Teil: Oscillatoriales, in Ettl, H., Gärtner, G., Heynig, H., and Mollenhauer, D., eds., Süßwasser flora von Mitteleuropa (Freshwater Flora From Central Europe), 19/2: Berlin, Spektrum Akademischer Verlag, 759 p.

Komárek, J., ed., 2013, Süßwasserflora von Mitteleuropa Bd 19/3 (Freshwater flora from Central Europe): Cyanoprokaryota 3: Heterocystous genera: Heidelberg, Springer Spektrum, 1130 p. https://doi.org/10.1007/978-3-8274-2737-3.

Lazarević, R., ed., 2012, Stopića pećina, Zlatibor, II dopunjeno izdanje(Stopić Cave, Zlatibor, $2^{\text {nd }}$ edition): Turistička Organizacija Zlatibor, p.94.

Li, P., Harding, E.S., and Liu, Z., 2013, Cyanobacterial exopolysaccharides: Their nature and potentional biotechnological applications: Biotechnology and Genetic Engineering Reviews, v. 18, no. 1, p. 375-404. https://doi.org/10.1080/02648725.2001.10648020. 
Lowe R.L., Kociolek J.P., Johansen J.R., Van de Vijver, B., Lange-Bertalot, H. and Kopalová, K., 2014 , Humidophila gen. nov., a new genus for a clade of diatoms (Bacillariophyta) formerly within the genus Diadesmis: species from Hawai i, including one new species: Diatom Research, v.29, p. 351-360. https://doi.org/10.1080/0269249X.2014.889039.

Lowe, R.L., Kociolek, J.P., You, Q., Wang, Q., and Stepanek, J., 2017, Diversity of the diatom genus Humidophila in karst areas of Guizhou, China: Phytotaxa, v. 305, no. 4, p. 269-284. https://doi.org/10.11646/phytotaxa.305.4.3.

Macedo, F.M., Miller, Z.A., Dionísio, A., and Saiz-Jimenez, C., 2009, Biodiversity of cyanobacteria and green algae on monuments in the Mediterranean Basin: an overview: Microbiology, v. 155, p. 3476-3490. https://doi.org/10.1099/mic.0.032508-0.

Marković, B., ed., 1957, Opšti pregled geološko-tektonskih osobina terena u dolini Velikog Rzava kod Drežnika (zapadnaSrbija) (General overview of the geological-tectonic features of terrain in VelikiRzav valley near Dreznik (West Serbia)): Zbornik radova Geološkog instituta, Jovan Žujović", knj. IX, Beograd.

Martinčić, A., Vrhovšek, D., and Batič, F., 1981, Flora v jamah z umetno osvetlitvijo (Flora in caves with artificial lighning): Biološki Vestnik, v. 29, p. 27-56.

Mazina, S.E., and Severin, A.V., 2007, Development of a method for rehabilitation of anthropogenically transformed underground ecosystems: The example of the New Athos Cave: Journal of Ecological Chemistry, v. 16, no. 3, p. 175-181.

Mazina, S.E., and Maximov, V.N., 2009, Photosynthetic organism communities of the Akhshtyrskaya Excursion Cave: Moscow University Biological Sciences Bulletin, v. 66, no. 1, p. 37-41. https://doi.org/10.3103/S009639251101007X.

Meyer, E., Seale, L.D., Permar, B., and McClary, A., 2017, The effect of chemical treatments on lampenflora and a Collembola indicator species at a popular tour cave in California, USA: Environmental Management, v. 59, no. 6, p. 1034-1042. https://doi.org/10.1007/s00267-017-0842-3.

Mulec J. 2008, Microorganisms in hypogeon: examples from slovenian karst caves: Acta Carsologica, v. 37, no. 1, p. 153-160.

Mulec, J., and Kosi, G. 2008, Algae in the aerophytic habitat of Račiške ponikve Cave (Slovenia): Natura Sloveniae, v. 10, no. 1, p. $39-49$.

Mulec, J., Kosi, G., and Vrhovšek, D., 2008, Characterization of cave aerophytic algal communities and effects of irradiance levels on production of pigments: Journal of Cave and Karst Studies, v. 70, no. 1, p. 3-12.

Mulec, J., and Kosi, G., 2009, Lampenflora algae and methods of growth control: Journal of Cave and Karst Studies, v. 71, no. 2, p. $109-115$.

Mulec, J., Krištůfek, V., and Chroňáková, A., 2012, Comparative microbial sampling from eutrophic caves in Slovenia and Slovakia using RIDA $®$ COUNT RIDACOUNT test kits: International Journal of Speleology, v. 41, no. 1, p. 1-8. https://doi.org/10.5038/1827-806X.41.1.1.

Pedersen, K., 2000, Exploration of deep intraterrestrial microbial life: current perspective. Mini Review: FEMS Microbiology Letters, v. 185, p. 9-16. https://doi.org/10.1111/j.1574-6968.2000.tb09033.x.

Pentecost, A., and Whitton, B.A., 2012, Subaerial Cyanobacteria, in: Whitton B.A. ed., Ecology of Cyanobacteria II: Their Diversity in Space and Time: London, Springer, p. 291-315. https://doi.org/10.1007/978-94-007-3855-3_10.

Piano, E., Bona, F., Falasco, A., La Morgia, V., Bađino, G., and Isaia, M., 2015, Environmental drivers of phototrophic biofilms in an Alpine show cave (SW - Italian Alps): Science of the Total Environment, v. 536, p. 1007-1018. https://doi.org/10.1016/j.scitotenv.2015.05.089.

Popović, S., Subakov Simić, G., Stupar, M., Unković, N., Predojević, D., Jovanović, J., and Ljaljević Grbić, M., 2015a, Cyanobacteria, algae and microfungi present in biofilm from Božana Cave (Serbia): International Journal of Speleology, v. 44, no. 2, p. 141-149. http://dx.doi. org/10.5038/1827-806X.44.2.4.

Popović, S., Subakov Simić, G., Stupar, M., Unković, N., Predojević, D., Blagojević, A. and Ljaljević Grbić M., 2015b, Cyanobacteria, algae and microfungi from Degurić cave, west Serbia: Abstract presented at 2015, 6th Balkan Botanical Congress, University Campus Rijeka, Croatia, p. 100, 14-18 September.

Popović, S., Jovanović, J., Predojević, D., Trbojević, I., Blagojević, A., Jakovljević, O., and Subakov Simić, G., 2016a, Cyanobacteria and algae from biofilms: the comparison of phototrophic microorganism community from cave entrance and lampenflora - Lazareva cave, Serbia: Abstract presented at 2016, 5th Congress of Ecologists of Macedonia, Macedonia (Ohrid) p.125, 19-22 October.

Popović, S., SubakovSimić, G., Korać, A., Golić, I., and Komarek, J., 2016b, Nephrococcus serbicus, a new coccoid cyanobacterial species from Božana Cave, Serbia: Phytotaxa, v. 289, no.2, p. 135-146. https://doi.org/10.11646/phytotaxa.289.2.3.

Popović, S., Jovanović, J., Predojević, D., Trbojević, I., Blagojević, A., and Subakov Simić, G., 2016c, Phototrophic microorganisms in biofilm samples from Vernjika Cave, Serbia: Abstract EGU2016-16064 presented at 2016 EGU General Assembly, Vienna, Austria. Geophysical Research Abstracts, v. 18, 17-22 April.

Popović, S., Subakov Simić, G., Stupar, M., Unković, N., Krunić, O., Savić, N., and Ljaljević Grbić, M., 2017a, Cave biofilms: characterization of phototrophic cyanobacteria and algae and chemotrophic fungi from three caves in Serbia: Journal of Cave and Karst Studies, v. 79, no. 1, p. 10-23. https://doi.org/10.4311/2016MB0124.

Popović, S., Jovanović, J., Blagojević, A., Trbojević, I., Predojević, D., Nikolić, N., Vidović, M., and Subakov Simić, G., 2017b, Diversity of epilithic and endolithic cyanobacteria and green algae at the entrance of two caves in Serbia: Abstract ISSN 0031-8884 presented at 2017, 11th International Phycological Congress, Szczecin, Poland, Phycologia, Congress Abstracts, v. 56, no.4, Supplement, p. 150-151. 13-19 August.

Smith, T., and Olson, R., 2007, A taxonomic survey of Lamp Flora (Algae and Cyanobacteria) in electrically lit passages within Mammoth Cave National Park, Kentucky: International Journal of Speleology, v. 36, no. 2, p. 105-114. https://doi.org/10.5038/1827-806X.36.2.6.

Ter Braak, C.J.F., and Šmilauer, P., 2012, Canoco reference manual and user's guide: software for ordination, version 5.0. Microcomputer Power, Ithaca, USA.

Tofilovska, S., Wetzel, E.C., Ector, L., and Levkov, Z., 2014, Observation on Achnanthes Bory sensu stricto (Bacillariophycae) from subaerial habitats in Macedonia and comparation with the type of material of A. coarctata (Brebisson ex W.Smith) Grunow, A. coarctata var. sinaensis Hustedt and A. intermedia Kutizing: Fottea,Olomouc, v. 14, no. 1, p. 15-42. https://doi.org/10.5507/fot.2014.002.

Trinh, D.A., Trinh, Q.H., Tran, N., Guinea, J.G., and Mattey, D., 2018, Eco-friendly remediation of lampenflora on speleothems in tropical karst caves: Journal of Cave and Karst Studies, v. 80, no. 1, p. 1-12 https://doi.org/10.4311/2017ES0101.

Urzi, C., and De Leo, F., 2001, Sampling with adhesive tape strips: an easy and rapid method to monitor microbial colonization on monument surfaces: Journal of Microbiological Methods, v. 44, p. 1-11. https://doi.org/10.1016/S0167-7012(00)00227-X.

Vinogradova, O.N., Kovalenko, O.V., Wasser, S.P., Nevo, E., and Weinstein-Evron, M., 1998, Species diversity gradient to darkness stress in bluegreen algae/cyanobacteria: a microscale test in a prehistoric cave, Mount Carmel, Israel: Isreali Journal of Plant Science. v. 46, p. 229-238. https://doi.org/10.1080/07929978.1998.10676732.

Vinogradova, O.N., Nevo, E., and Wasser, S.P., 2009, Algae of the Sefunim Cave (Israel): species, diversity affected by light, humidity and rock stresses: International Journal of Algae, v. 11, p. 99-116. https://doi.org/10.1615/InterJAlgae.v11.i2.10. www. clipart-library.com. 
Francesco Ballarin. Domitius Culsu sp. nov. (Araneae, Nesticidae), a new troglobiont spider from Italy with notes on Italian nesticids of the genus Domitius Ribera, 2018. Journal of Cave and Karst Studies, v. 82, no. 2, p. 82-94. DOI:10.4311/2019LSC0103

\title{
DOMITIUS CULSU SP. NOV. (ARANEAE, NESTICIDAE), A NEW TROGLOBIONT SPIDER FROM ITALY WITH NOTES ON ITALIAN NESTICIDS OF THE GENUS DOMITIUS RIBERA, 2018
}

\author{
Francesco Ballarin ${ }^{1,2}$
}

\begin{abstract}
Seven species from the spider family Nesticidae are currently known for the Italian fauna. Three Italian nesticids belong to the newly-established genus Domitius Ribera, 2018. All these species show a restricted distribution along the Apennine mountain chain and deep adaptation to cave life. Herein, a fourth species, $D$. culsu sp. nov. from a single cave in Northern Apennines is described. Detailed illustrations and diagnosis of the new species are provided. Molecular and morphological analysis of both sexes of $D$. culsu sp. nov. supports the validity of the new species and its close relationship with the other Domitius species from the same geographical area. A close affinity with the species distributed in the Iberian Peninsula is also observed. The potential susceptibility of $D$. culsu sp. nov. to external disturbance, and its extremely limited distribution, makes this spider of interest for conservation.
\end{abstract}

\section{INTRODUCTION}

Nesticidae Simon, 1894 is a small family of spiders with a worldwide distribution. Currently, 278 species and 16 genera are recognized (World Spider Catalog, 2020). At temperate latitudes, nesticids mostly occur in dark, damp environments such as caves, often showing high levels of endemism. Previously, the majority of nesticid species were included in the genus Nesticus Thorell, 1869. Nesticus has recently been partially revised (Lin et al., 2016; Pavlek and Ribera, 2017; Ribera, 2018) and several of its European species moved to different genera (e.g. Typhlonesticus Kulczyński, 1914, Kryptonesticus Pavlek and Ribera, 2017, Domitius Ribera, 2018).

Eight nesticid species belonging to five genera are currently known in Italy: Domitius menozzii (di Caporiacco, 1934), D. sbordonii (Brignoli, 1979), D. speluncarum (Pavesi, 1873), Eidmannella pallida (Emerton, 1875), Kryptonesticus eremita (Simon, 1880), Nesticus cellulanus (Clerck, 1757), Typhlonesticus idriacus (Roewer, 1931), and T. morisii (Brignoli, 1975) (Pantini and Isaia, 2019). The Italian Domitius species are all considered troglobionts (Mammola and Isaia, 2017) showing extreme adaptations to the subterranean environment (e.g. reduction of eyes, depigmentation, and elongation of legs). Such spiders are characterized by a limited distribution, and are endemic to a small number of caves in Northern (D. menozzii, D. speluncarum) or Central (D. sbordonii) Apennines mountains (Brignoli, 1979, Ribera, 2018). Initially, the taxonomy and geographic range of $D$. menozzii and $D$. speluncarum were uncertain: the two species were often mistaken for each other, or considered as subspecies or a synonymy of K. eremita (see Brignoli, 1971 202-205, in Italian). Dresco (1966) and Brignoli (1971) revised the taxonomy of $D$. menozzii and $D$. speluncarum, pinpointing their differences. Nevertheless, there is still occasional confusion regarding their taxonomic status: for example, $D$. speluncarum is sometimes wrongly attributed to the Dinaric Alps (Pavlek and Ribera, 2017).

Individuals of $D$. speluncarum and $D$. menozzii were found by the author while collecting in caves in Liguria and Toscana Regions (Italy). Specimens from one cave appeared to show distinct morphological differences. A more detailed examination of genitalia revealed that those specimens represented a new species. In this paper, the new species is described. The morphological differences between the Italian Domitius species are explored in detail, and the precise geographical distribution of the genus in the Italian peninsula is illustrated. To better establish the systematic position of the species, a phylogenetic tree of the genus Domitius, in relation with the other main European nesticid genera, is carried out.

\section{MATERIAL AND METHODS}

\section{Taxonomy}

Fresh specimens were hand-collected in caves and fixed in $96 \%$ ethanol for molecular and morphological analysis. Photographs and measurements of the samples were taken at the Museo Civico di Storia Naturale of Verona, Italy, using a Leica DFC450 digital camera mounted on a Leica M165C steremicroscope. A Leiz Diaplan microscope was used to photograph the vulvae. Images were subsequently combined using Helicon Focus 6 image stacking software. The left palps of males were photographed. Epigynes were dissected using a sharp needle and boiled for a few minutes in a $20 \%$ $\mathrm{KOH}$ solution to show the vulval internal structures. Leg measurements are given as following: total length (femur, patella,

${ }_{1}^{1}$ Systematic Zoology Laboratory, Department of Biological Sciences, Tokyo Metropolitan University 1-1 Minami-Osawa, Hachioji-shi, Tokyo, 192-0397, Japan. ballarin.francesco@gmail.com.

2 Department of Zoology, Museo Civico di Storia Naturale of Verona, Lungadige Porta Vittoria, 9 I-37129 Verona, Italy. 
tibia, metatarsus, tarsus). All measurements are reported in millimeters. Unless otherwise specified, type descriptions are based on wet specimens in ethanol. Specimens used in this study are stored in the collections of the Museo Civico di Storia Naturale of Verona (MSNV) and Museo Civico di Storia Naturale "E. Caffi" of Bergamo (MSNB). The following abbreviations are used in the text and figures: $A M=$ anterior median eyes; $A L=$ anterior lateral eyes; $C=$ conductor complex; $\mathrm{Cd}=$ copulatory duct; $\mathrm{Co}=$ copulatory opening; Da 1-3 = dorsal apophyses of the paracymbium; $\mathrm{Di}=$ distal apophysis of the paracymbium; $\mathrm{E}=$ embolus; $\mathrm{Id}=$ insemination duct; $\mathrm{Ma}=$ median apophysis; $\mathrm{Ms}=$ median septum; $\mathrm{P}=$ paracymbium; $\mathrm{Pc} 1-3=$ processes of the conductor complex; $\mathrm{PM}=$ posterior median eyes; $\mathrm{PL}=$ posterior lateral eyes; $\mathrm{S}=$ spermatheca; $\mathrm{St}=$ subtegulum; $\mathrm{T}=$ tegulum; $\mathrm{Va}=$ ventral apophysis of the paracymbium; $\mathrm{Vp}=$ vulval pocket.

\section{Breeding}

To increase the available number of adult specimens and to obtain information about the life-cycle of the species for further research, juveniles of $D$. culsu sp. nov. at different growth stages were collected and raised in captivity in the basement of the Museo Civico di Storia Naturale of Verona. Each specimen was kept in a box (size $10 \times 5 \times 3 \mathrm{~cm}$ ) made of plaster, with a glass lid and a layer of cave mud on the bottom. All boxes were placed in a large plastic tray with a transparent plexiglass lid and a layer of plaster on the bottom. To maintain the correct degree of humidity, the bottom of the tray was moistened with water every two weeks. Specimens were frequently checked and fed with fruit flies or mosquitoes approximately once or twice per month.

\section{Molecular Analysis}

Sequences of Domitius species and other European nesticids were obtained from freshly collected specimens or acquired from the GenBank online database (GenBank, 2018). Since preliminary phylogenetic analysis of the family suggests Gaucelmus is a sister clade to all Nesticidae sensu stricto (Ballarin and Li, in prep.), Gaucelmus augustinus Keyserling, 1884 from North America was set as an outgroup to root the tree. Extraction of DNA, and PCR amplification, were performed in the Institute of Zoology, Chinese Academy of Sciences, Beijing, China (IZCAS). All fresh specimens used for the molecular analysis were identified at species level using morphology, before storing at $-20^{\circ} \mathrm{C}$ at IZCAS. For each species, total genomic DNA was extracted from two legs of an adult specimen using a TIANamp Genomic DNA Kit (TIANGEN) under the standard protocol suggested by the manufacturer. The PCR amplifications were performed with an Eppendorf thermal cycler (Hamburg, Germany) using a final volume of 25 $\mu \mathrm{L}$. Purified PCR products were sequenced in both directions using an ABI 377 automatic sequencer (Applied Biosystems, Foster City, CA, USA) with a BigDye terminator cycle sequencing ready reaction kit. Partial fragments of the mitochondrial genes cytochrome c oxidase subunit I (COI) and 16S rRNA (16S) and the nuclear gene Histone $\mathrm{H} 3(\mathrm{H} 3)$ were selectively amplified following protocols and primers as indicated in Ballarin and $\mathrm{Li}$ (2018). Raw sequences were aligned using the online version of MAFFT v.7.0 (Katoh and Standley, 2013) under the algorithms G-INS-i for COI and H3 and Q-INS-i for 16S. Aligned sequences were subsequently visually inspected for mismatching and edited with BioEdit v.7.2.5 (Hall, 1999). A Maximum Likelihood (ML) analysis under a GTRGAMMA nucleotide substitution model was performed using the online version of RAxML v.8.2.0 (Stamatakis, 2014) on CIPRES Science Gateway V. 3.3 (Miller et al. 2010, available at: https://www.phylo.org/). One thousand replicates of rapid bootstrap were performed twice, using an individual gene partition scheme. Uncorrected pairwise-distance genetic divergences between the species was performed using MEGA v.7.0.14 (Tamura et al., 2013). The list of species used in the analysis and related GenBank accession numbers of the sequences are reported in Table 1.

\section{RESULTS}

\section{Taxonomy}

Class Arachnida Cuvier, 1812

Order Araneae Clerck, 1757

Family Nesticidae Simon, 1894

Genus Domitius Ribera, 2018

Domitius culsu Ballarin sp. nov.

Figures $1 \mathrm{~A}-\mathrm{G}, 2 \mathrm{~A}-\mathrm{E}, 3 \mathrm{~A}-\mathrm{D}$.

Nesticus speluncarum Brignoli, 1979: 214 (misidentification)

Type material. Holotype $\widehat{\delta}$. ITALY, Toscana: Garfagnana area, Lucca Province, Coreglia Antelminelli Municipality, Tana delle Fate di Coreglia Antelminelli cave, 141/T/LU, $260 \mathrm{~m}$ a.s.I., $44.046336^{\circ} \mathrm{N} 10.523525^{\circ} \mathrm{E}, 21 . \mathrm{VIII} .2018$, leg. F. Ballarin and D. Avesani (MSNV). Paratypes. Same locality as the holotype, 19, 04.IX.1967, leg. A. Vigna Taglianti (MSNV) (Brignoli 1979, sub Nesticus speluncarum); 1울. 15.VIII.2015, leg. F. Ballarin and M. Gaiga (MSNV); 4우으, 24.VI.2017, (3우 collected as juveniles and raised in captivity, adults: 20.VIII.2017, 15.IX.2017 and 28.VI.2018 respectively), leg. F. Ballarin and R. Ballarin (MSNV); 4ㅇ, 21.VIII.2018, leg. F. Ballarin and D. Avesani (MSNV, MSNB). 
Table 1. Species, GenBank accession numbers, and locality of the specimens used in the phylogenetic analysis.

\begin{tabular}{|c|c|c|c|c|c|}
\hline Species & Code & COI & $16 S$ & H3 & Locality \\
\hline Domitius baeticus & Dbae & MF693114 & MF693118 & MF693106 & Cueva del Castillo. Siles, Jaén. Spain \\
\hline Domitius luquei & Dluq & MF693112 & EU746439 & MF693104 & $\begin{array}{l}\text { Cueva de la Picona, San Pedro de Carmona, Cabuérniga, } \\
\text { Cantabria, Spain }\end{array}$ \\
\hline Domitius lusitanicus & Dlus & MF693113 & EU746429 & MF693105 & Algar de Marradinhas II, Concelho de Alcanena, Portugal \\
\hline Domitius menozzii & D213 & MK860151 & MK860133a & MK860142a & Tanna da Suja, Prati di Bavari, Liguria, Italy \\
\hline Domitius culsu sp. nov. & D555 & MK860152a & MK860134 & MK860143a & $\begin{array}{l}\text { Tana delle Fate di Coreglia Antelminelli, Coreglia } \\
\text { Antelminelli, Toscana, Italy }\end{array}$ \\
\hline Domitius sbordonii & Dsbo & MF693110 & MF693116 & MF693102 & Tana degli orchetti, Supino, Lazio, Italy \\
\hline Domitius speluncarum & D557 & MK860153a & MK860135 & MK860144 ${ }^{a}$ & Tana di Magnano, Canigiano, Lucca, Toscana, Italy \\
\hline Nesticus cellulanus & N214 & MK860154 & MK860136 & MK860145 & Cave of Koufovouno, Didimoticho, Thrace, Greece \\
\hline Kryptonesticus dimensis & K566 & MK860155 & MK860137a & MK860146 & Dim cave, Antalya, Turkey \\
\hline Kryptonesticus eremita & K211 & MK860156a & MK860138 & MK860147a & Grotta di Ponte Subiolo, Mori, Veneto, Italy \\
\hline Carpathonesticus fodinarum & C162 & MK860157 & MK860139a & MK860148 & Small cave along the river, Sighistel, Bihor, Romania \\
\hline Carpathonesitcus lotriensis & C166 & MK860158 & MK860140a & MK860149a & $\begin{array}{l}\text { Humid and shadowed cliff near Lazaret village, Sibiu, } \\
\text { Romania }\end{array}$ \\
\hline Typhlonesticus obcaecatus & Tobc & KF939309 & EU746437 & MF693109 & Cueva del Molino de Aso, Boltana, Huesca, Spain \\
\hline Typhlonesticus idriacus & T167 & MG201050 & MG200521 & MG201227 & Grotta Pre Oreak, Nimis, Udine, Friuli Venezia Giulia, Italy \\
\hline Typhlonesticus morisii & Tmor & KF939311 & KF939308 & $\cdots$ & Sotterranei del Forte di Vernante, Vernante, Cuneo, Italy \\
\hline Gaucelmus augustinus & G601 & MK860159a & MK860141 & MK860150 & Climax cave, Bainbridge, Georgia, USA \\
\hline
\end{tabular}

a New Sequences.

Examined comparative material. Domitius speluncarum (Pavesi, 1873): ITALY: Liguria: 10ิ, 1, (topotypes), La Spezia Province, Grotta Bocca Lupara cave, 74/Li/SP, 120m a.s.I., 05.III.1969, leg. P.M. Brignoli (MSNV) (Brignoli, 1971); Toscana: 1이 Lucca Province, Garfagnana area, Villa Collemandina Municipality, Canigiano village, Tana di Magnano cave, 162/T/LU, 653m a.s.I., 44.177285 $\mathrm{N}, 10.38803^{\circ} \mathrm{E}, 03 . X I .1967$, leg. A. Vigna Taglianti (MSNV) (Brignoli,


volasco (not reported in the label but very likely from Grotta del Vento cave), 700m a.s.l., 16.VI.1970, leg. O. Osella (MSNV) (Brignoli, 1971); 1, Grotta del Buggine cave, 166/T/Lu, 315m a.s.l., 07.X.1967, leg. G. Castellini (MSNV) (Brignoli, 1971); 1오․ Massa-Carrara, Buca della Freddana cave, 230/T/Ms, 550m a.s.l., 05.VI.1977, leg. C. Bonzano (MSNV) (Brignoli, 1985); 1오․ Buca del Bacile cave, 226/T/Ms, 10.III.1975, leg. unknown (MSNV) (Brignoli, 1985).

Domitius menozzii (di Caporiacco, 1934): ITALY, Liguria, $1 \hat{\delta}, 4+q$, north-east of Genova town, Tanna da Vulpe cave, 264/Li/GE, 23.XI.1969, leg. A. Vigna Taglianti (MSNV) (Brignoli, 1971); 2ððð, 2우, Creto, Tanna de Fate cave, 17/ Li/GE, 30.X.1971, leg. G. Gardini (MSNV); 2 o (topotypes), Prati di Bavari locality, Tanna da Suja cave, 5/Li/GE, 582m a.s.I., $44.422894^{\circ} \mathrm{N}, 09.035239^{\circ} \mathrm{E}, 30 . \mathrm{V} .2013$, leg. F. Ballarin, A. Trotta, G. Gardini, and S. Zoia.

Domitius sbordonii (Brignoli, 1979): ITALY, Lazio, $1{ }^{\widehat{A}}$ (holotype), Frosinone Province, Supino, Valle Serena, Grotta della Croce cave, 01.IX.1977 leg. V. Sbordoni (MSNV) (Brignoli, 1979); 1 ㅇ (paratype), 08.Il.1976, leg. V. Sbordoni (MSNV) (Brignoli, 1979).

Kryptonesticus eremita (Simon, 1880): ITALY, Liguria: $2 \hat{\jmath} \widehat{\jmath}$ (sub. Nesticus menozzii), Creto, Tanna de Fate cave, 17/Li/GE, 30.X.1971, leg. G. Gardini (MSNV); Emilia-Romagna: $2+q$ Ravenna Province, Riolo Terme, Borgo Rivola, Grotta del Re Tiberio cave, 36/Er/RE. 19.Il.1951, Leg. Denis (MSNV) (Zangheri, 1966, sub. Nesticus speluncarum); Toscana: 1 q Garfagnana area, Lucca Province, Coreglia Antelminelli Municipality, Tana delle Fate di Coreglia Antelminelli cave, $141 / \mathrm{T} / \mathrm{LU}, 260 \mathrm{~m}$ a.s.I., $44.046336^{\circ} \mathrm{N}, 10.523525^{\circ} \mathrm{E}, 15 . \mathrm{VIII} .2015$, leg. F. Ballarin and M. Gaiga (MSNV); 3우, 24.VI.2017, Leg. F. Ballarin and R. Ballarin (MSNV-MSNVRAr/m 0007); 1, 21.VIII.2018, leg. F. Ballarin and D. Avesani (MSNV); Campania: 1, Avellino Province, Bagnoli Irpino, Mt. Piacentini, Grotta Giovannino cave, 16.VI.1956, leg. S.Ruffo (MSNV) (Kritscher, 1958, sub. Nesticus speluncarum).

\section{Etymology}

The name of the new species is derived from the Etruscan goddess Culsu who, according to the Etruscan mythology, ruled the cave-like entrance of the underworld. Noun in apposition. 

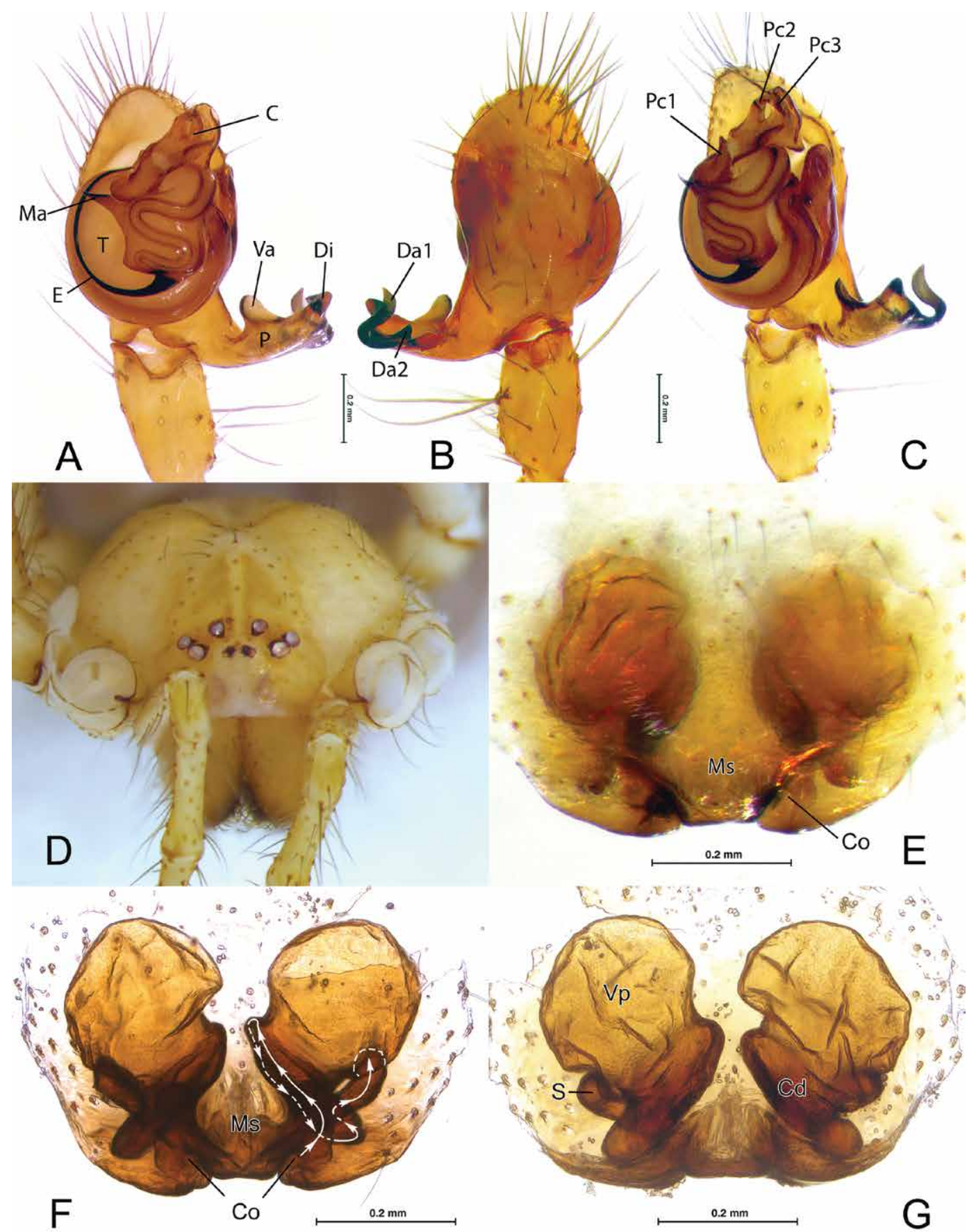

Figure 1. Nesticus culsu sp. nov. Male palp: A. ventral view; B. dorsal view; C. retrolateral view; D. female, cephalic region showing the eye pattern; E. epigyne, ventral view; F. epigyne after clearing, ventral view, the schematic course of internal ducts is outlined with a white line; G. vulva after clearing, dorsal view.

\section{Diagnosis}

Species closely related to $D$. speluncarum and D. menozzii. Males of $D$. culsu sp. nov. can be separated from males of all other Italian species of the genus Domitius by the different shape of the apophyses of the paracymbium (Figs. $1 \mathrm{~A}-\mathrm{C}$, $2 \mathrm{~B}, \mathrm{C}$ vs. Fig. $4 \mathrm{~A}-\mathrm{I})$. $D$. culsu sp. nov shows a robust, S-shaped dorsal apophysis 1 in contrast with a large, flat and axelike Da 1 in $D$. speluncarum (Figs. 1A-C, 2B, C vs. Fig. $4 A-C)$; a short and stumpy $D a 1$ in $D$. menozzii (Figs. 1A-C, 2B, C vs. Fig. 4D-F) or a long and thread-like $\mathrm{Da} 1$ in D. sbordonii (Figs. 1A-C, 2B, C vs. Fig. 4G-I). Additionally, males of $D$. culsu sp. nov. have a well-developed, triangular median apophysis, absent in males of the other three species (Figs. 1A, 2A vs. Fig. 4A, D, G).

Female $D$. culsu sp. nov. can be easily distinguished from female $D$. speluncarum by the narrower, trapezoid-shaped median septum with slanting edges, in contrast with the larger, lobate Ms with rounded edges in $D$. speluncarum (Figs. 1E, 2D vs. Fig. 5A). Female $D$. culsu sp. nov. are separated from female $D$. morisii by the absence of a bulge on the Ms (clearly visible in D. morisii, Figs. 1E, 2D vs. Fig. 5C). Additionally, they can be distinguished by the different shape of copulatory ducts when the vulva is observed dorsally: with a rather uniform diameter in $D$. culsu sp. nov. and bearing a large, flattened middle trait in $D$. morisii (Figs. 1G, 2E vs. Fig. 5D). Female $D$. culsu sp. nov. are easily separated from those of $D$. sbordonii by the trapezoid-shaped Ms with slanting edges, in contrast with the squared Ms with vertical edges in $D$. sbordonii (Figs. 1E, 2D vs. Fig. 5E). They can further be distinguished by the different position of spermathecae, located in the lower half of the vulva and below the vulval pockets in $D$. culsu sp. nov., in contrast with $S$ located in the upper half of vulva and above Vp in $D$. sbordonii (Figs. 1G, 2E vs. Fig. 5F). 


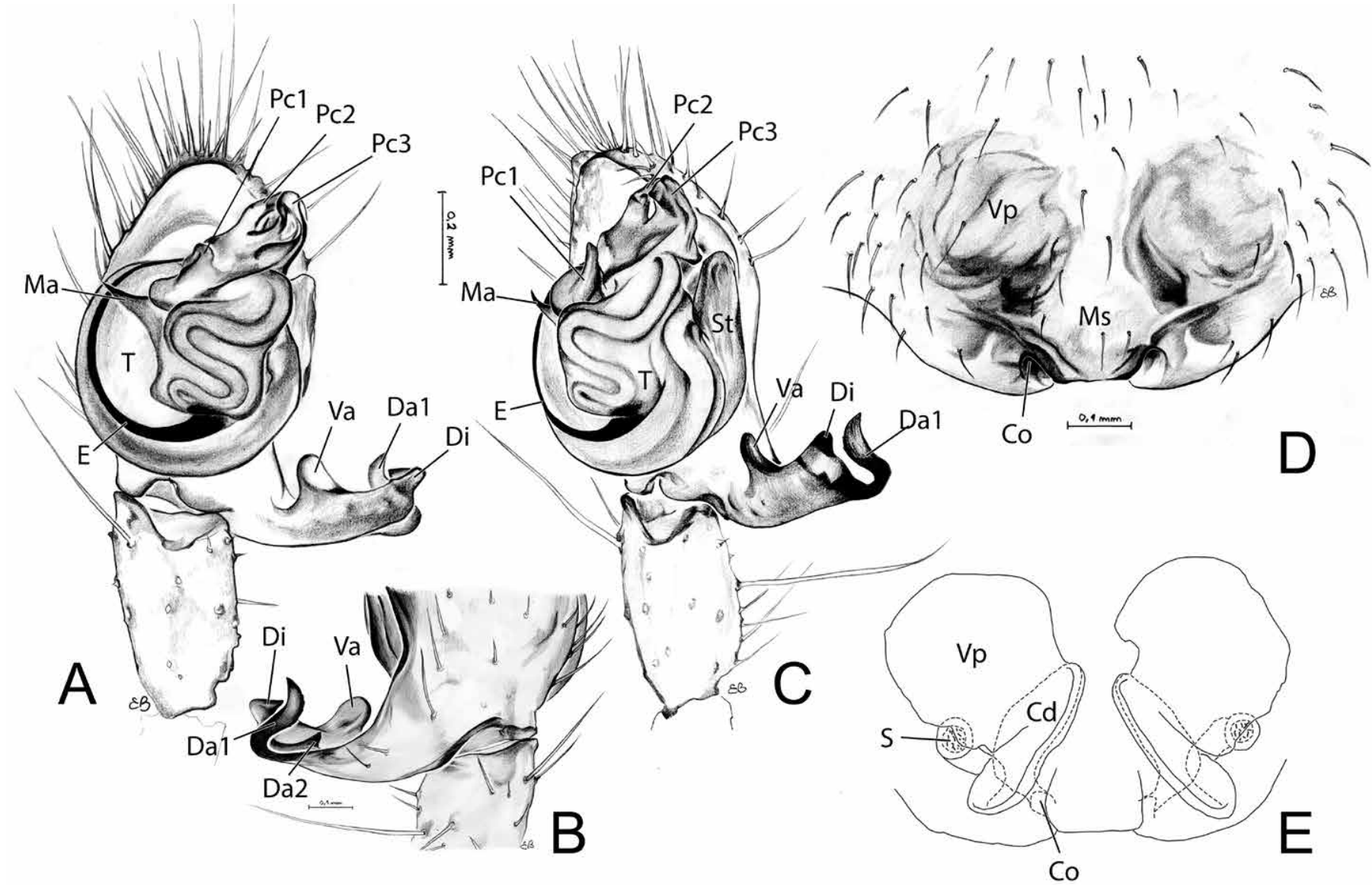

Figure 2. Genitalia of Nesticus culsu sp. nov. Male palp: A. ventral view; B. dorsal view of the paracymbium; C. retrolateral view; D. female epigyne, ventral view; E vulva, dorsal view.

Description. Male (holotype). Total length 4.19. Carapace: 1.81 long, 1.56 wide.

Habitus as in Fig. 3A. Carapace uniformly pale yellow with some sparse setae (more reddish while alive, see Fig. $3 A$ ). Cephalic region not clearly differentiated from the rest of carapace. Eyes reduced, AM missing, reduced to black maculae. Eye diameters: AM -, AL 0.079, PM 0.080, and PL 0.078. Thoracic grooves and fovea distinct. Mouthparts and sternum uniformly colored as the carapace. Promargin of chelicera with three teeth approximately of the same size, retromargin with several small denticles. Legs uniformly light yellowish. Legs measurements as follows: I 17.40 (4.89, 0.90, 4.78, 4.90, 1.93), II 14.03 (3.92, 0.80, 3.67, 3.76, 1.88), III 10.35 (3.19, 0.69, 2.53, 2.79, 1.15), IV 13.47 (4.34, 0.84, $3.53,3.49,1.27)$. Leg formula: I, II, IV, III. Opisthosoma gray-yellowish colored (lighter than carapace while alive, see Fig. 3A), covered with long hairs.

Palp as in Figs. 1A-C, 2A-C. Cymbium oval, covered with short, sparse setae, with a tuft of longer hairs in the prolateral distal area near the tip. Embolus filamentous, slender in the terminal part. Conductor complex with three distinct processes: Cp 1-3. Cp 1 stocky and roughly triangularly shaped, $\mathrm{Cp} 2$ and $\mathrm{Cp} 3$ located at the distal part of the bulb and diagonally protruding (approx. 2 o'clock seeing the left palp ventrally), their tips curved towards each other (Figs. 1A, C, 2A, C). Median apophysis well-developed, shaped as a long, sharp triangle, heading prolaterally (Figs. 1A, 2A). Paracymbium large with well-developed, sclerotized dorsal, distal and ventral processes. Two dorsal apophyses, Da 1-2: Da 1 robust and long, ending sharply, S-shaped when the palp is observed dorsally, Da 2 stocky, triangularly-shaped. Distal apophysis triangularly shaped. Ventral apophysis lobate, dorso-ventrally flattened and heading toward the cymbium (Figs. 1A-C, 2A-C).

Female (based on 4 paratypes). Total length 3.65-5.27. Carapace: 1.71-1.98 long, 1.54-1.64 wide.

Habitus as in Fig. 3B, C. Carapace uniformly yellowish with some sparse setae (often more reddish while alive, see Fig. 3B). Cephalic region not clearly differentiated from the rest of the prosoma. Eyes reduced, AM strongly reduced and barely visible, reduced to small, dark maculae in some specimens. Eye diameters: AM (when present): 0.032, AL: 0.087, PM: 0.078 , and PL: 0.77 . Thoracic grooves and fovea distinct. Mouthparts and sternum uniformly colored as in the carapace. Teeth of chelicera as in the male. Legs uniformly light yellowish. Leg measurements as follows: I 17.07 (4.38, 1.01, 4.95, 4.90, 1.83), II 13.69 (4.04, 0.92, 3.57, 3.64, 1.52), III 10.46 (3.43, 0.80, 2.50, 2.56, 1.17), IV 13.89 (4.64, 0.92, 3.59, 3.41, 

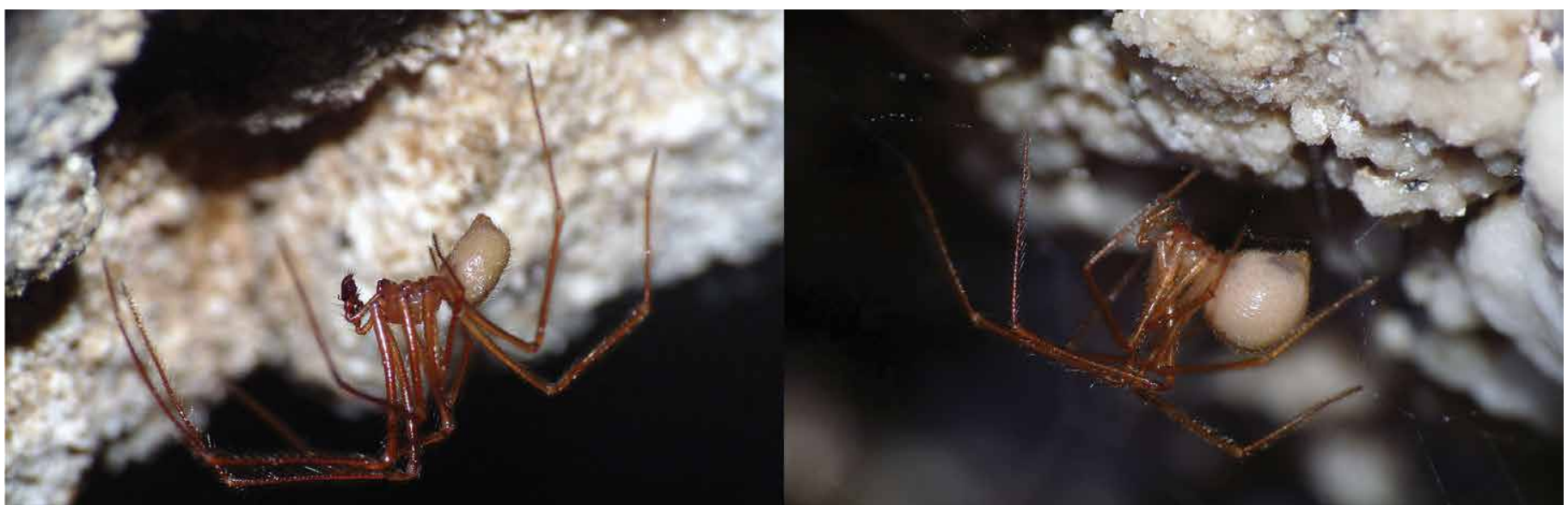

A

$\mathrm{B}$
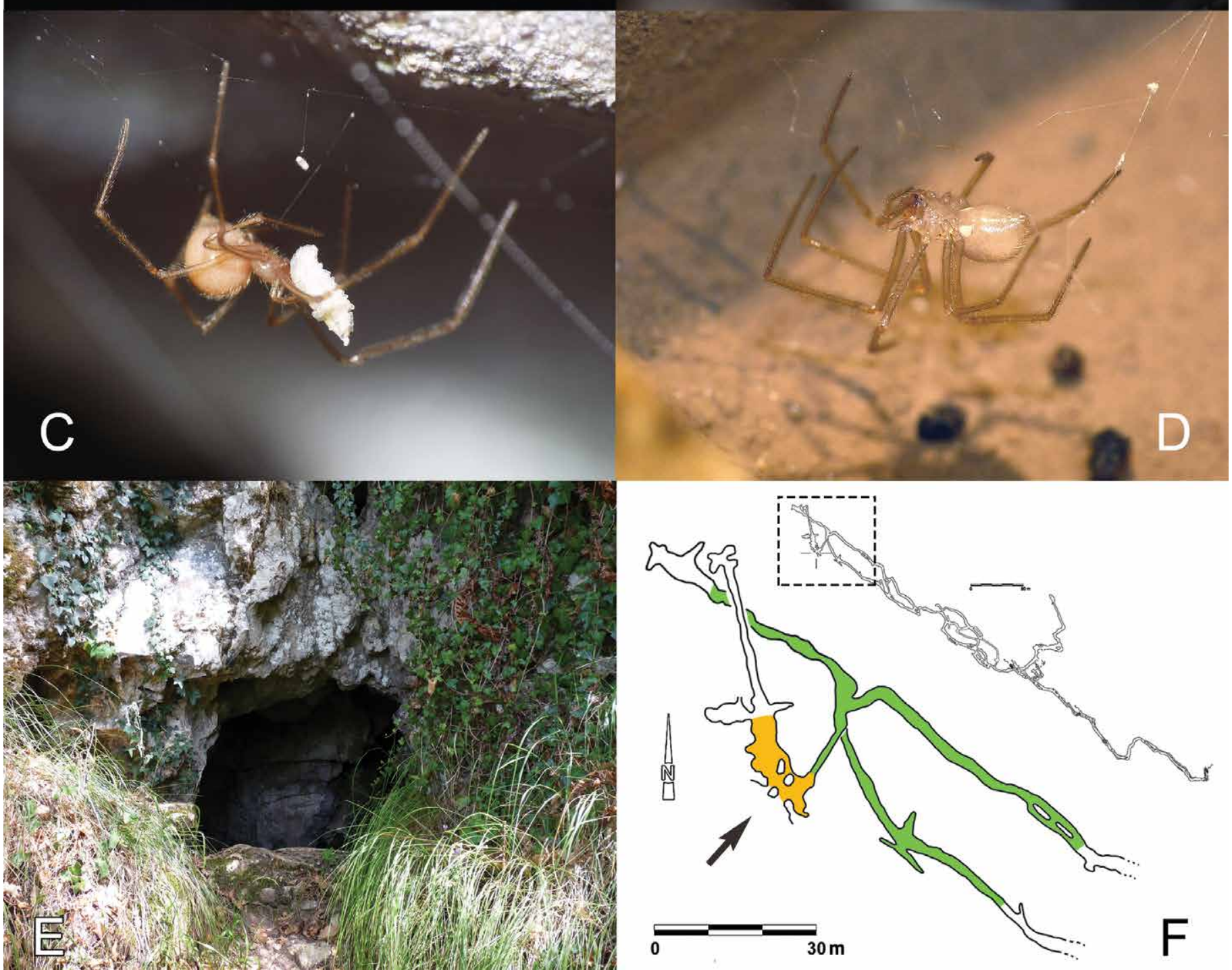

Figure 3. Habitus and type locality of Domitius culsu sp. nov. A. Habitus of male; B. habitus of female; C. female with prey; D. juvenile in captivity; E. entrance of Tana delle Fate di Coreglia Antelminelli cave; F. map of the cave and detail of the entrance, showing the spatial distribution of the two co-existing nesticid species living inside: green $=D$. culsu sp. nov., orange $=$ Kryptonesticus eremita, arrow $=$ entrance of the cave. 


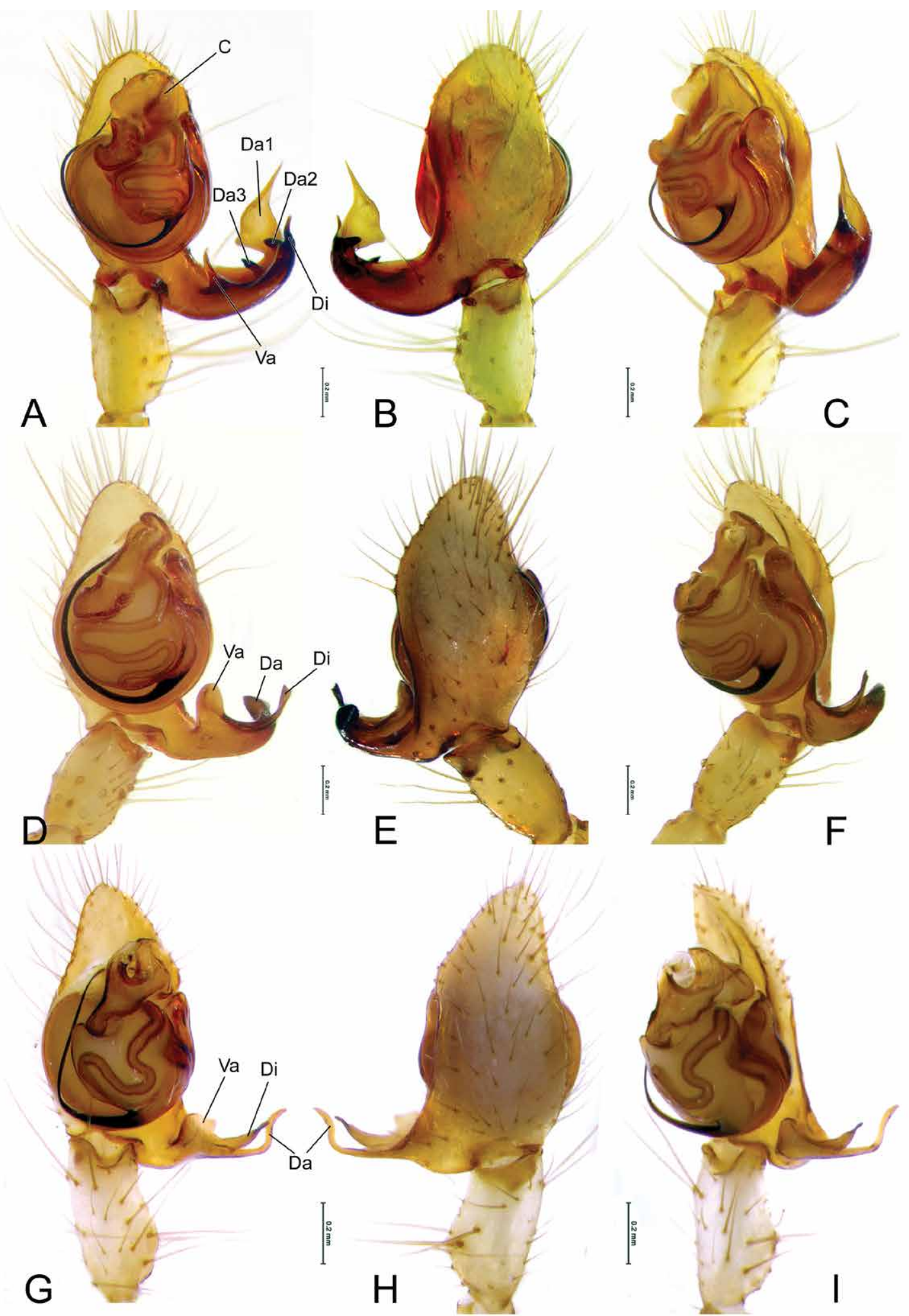

Figure 4. Male palps of the Italian Domitius species for comparison. D. speluncarum male palp: A. ventral view; B. dorsal view; C. retrolateral view; $D$. menozzii male palp: D. ventral view; E. dorsal view; F. retrolateral view; $D$. sbordonii male palp: G. ventral view; H. dorsal view; I. retrolateral view.

nines. Known only from the type locality; Tana delle Fate di Coreglia Antelminelli cave (Fig. 6).
1.33). Leg formula: I, IV, II, III. Opisthosoma yellowish-gray (often lighter colored than carapace while alive, see Fig. 3B), covered with long hairs.

Epigyne as in Figs. 1E, F, 2D, E. Median septum short, not protruding, shaped as an inverted trapezoid with a narrower base. Vulval pockets and copulatory ducts externally visible by transparence trough the tegument. Copulatory openings at the lower, lateral side of median septum. Vulva as in Figs. 1G, 2E. Spermathecae small and round, located in the lower-half of the vulva, below vulval pockets and being partially covered by them. Vulval pockets wide and rounded, sac-shaped, located above spermathecae. Copulatory ducts with a wider diameter in the ventral trait and narrower in the dorsal trait, rolling up around the lower part of vulval pockets and reaching spermathecae with some turns (Figs. 1F, 2E). Insemination ducts beginning from the lower part of spermathecae and following the same course of copulatory ducts.

\section{Distribution}

Italy, endemic to the northern Apen- 


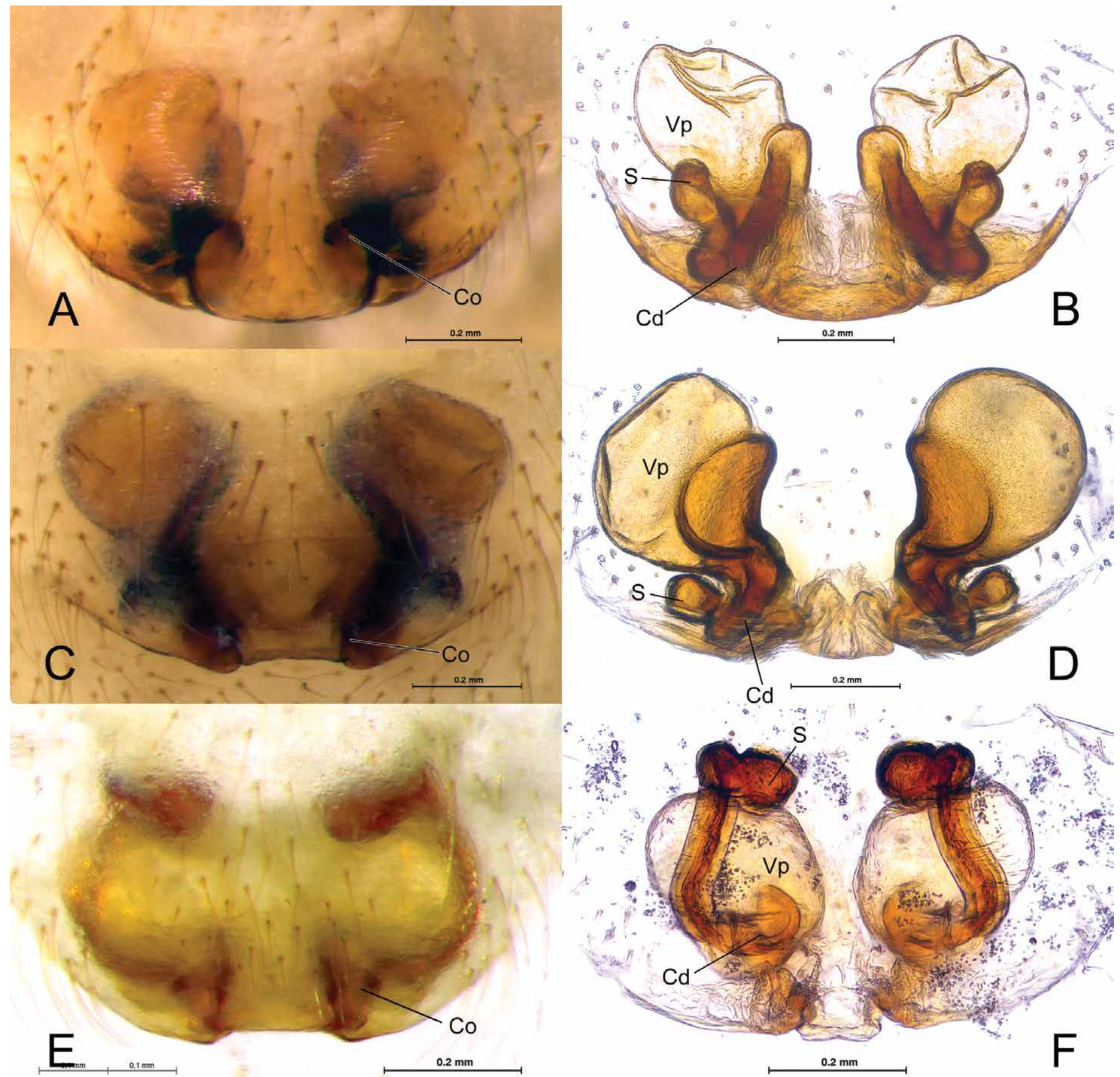

Figure 5. Female epigyne of the Italian Domitius species for comparison. D. speluncarum: A. epigyne, ventral view; B. vulva, dorsal view; D. menozzii: C. epigyne, ventral view; D. vulva, dorsal view; $D$. sbordonii: E. epigyne, ventral view; F. vulva.

\section{Biospeleological and ecological notes}

The entrance of Tana delle Fate di Coreglia Antelminelli cave (Italian National Caves Registry number: 141/T/LU; Fig. 3E) opens in the left bank of the narrow valley of Segone Creek in the Province of Lucca (Toscana region) at an elevation of $260 \mathrm{~m}$ a.s.l. The cave occurs in the limestone of the Maiolica formation (lower Tithonian-lower Aptian, $\sim 150-120 \mathrm{Ma}$ ), which is particularly rich in flint nodules. After an initial steep slope (approximately $10 \mathrm{~m}$ deep), the cave continues with a long and sub-horizontal spatial development and a general NW-SE orientation (Fig. 3F). It branches with several, sub-circular tunnels as a result of ancient groundwater flows. The cave has an estimated total extension of $1100 \mathrm{~m}$, although the deeper segments are still unexplored, as they are either filled with water or ending with sumps. The inner section is generally humid, with mud often covering the bottoms of the tunnels. The cave hosts a rich subterranean fauna including some endemic or locally protected species, e.g. the carnivorous land snail Oxychilus sp. (Gastropoda, Oxychilidae), the cave cricket Dolichopoda laetitiae Minozzi, 1920 (Orthoptera, Rhaphidophoridae), the 


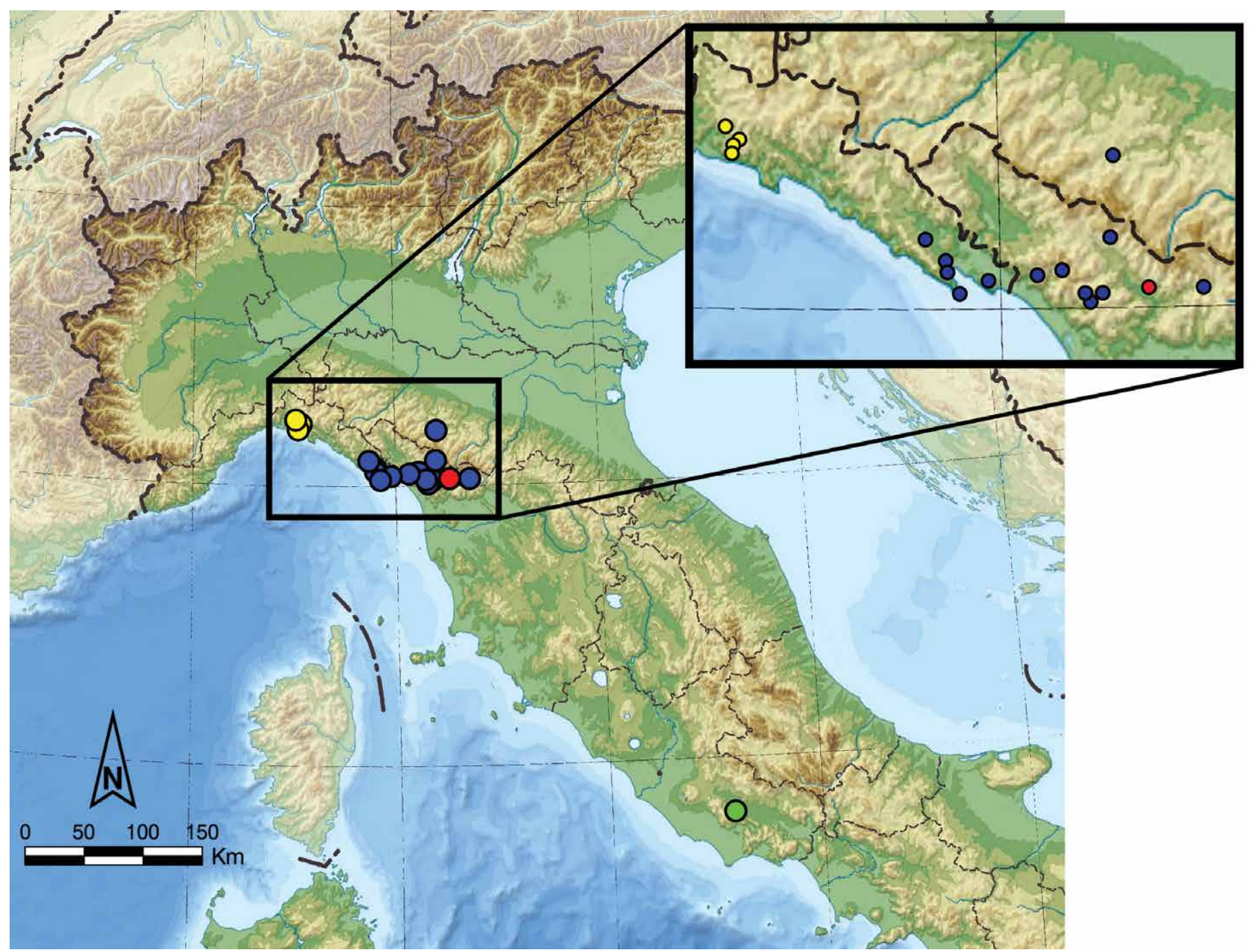

Figure 6. Distribution of the genus Domitius in Italy. Yellow dots $=D$. menozzii, blue dots $=D$. speluncarum; red dot $=D$. culsu sp. nov.; green dot $=D$. sbordonii.

blind subterranean beetle Duvalius apuanus lanzai Straneo, 1943 (Coleoptera, Trechinae), the Italian cave salamander Speleomantes italicus (Dunn, 1923) (Amphibia, Plethodontidae), and three species of bats: the greater horseshoe bat Rhinolophus ferrumequinum (Schreber, 1774), the lesser horseshoe bat Rhinolophus hipposideros (Bechstein, 1800) (Chiroptera, Rhinolophidae), and the common bent-wing bat Miniopterus schreibersii (Kuhl, 1817) (Chiroptera, Miniopteridae). Other animals known from the cave from the literature (Lanza, 1961) or directly observed by the author include: Octodrilus complanatus (Dugès, 1828), O. hemiandrus (Cognetti, 1901), O. transpadanus (Rosa, 1884), and Aporrectodea rosea (Savigny, 1826) (Anellida, Lumbricidae); Chaetophiloscia cellaria (Dollfus, 1884) (Isopoda, Philosciidae), Androniscus dentiger Verhoeff, 1908, and Spelaeonethes mancinii (Brian, 1913) (Isopoda, Trichoniscidae); Euscorpius carpathicus (Linnaeus, 1767) (Scorpiones, Euscorpiidae); Trogulus sp. (Opiliones, Trogulidae), Ischyropsalis adamii Canestrini, 1873 (Opiliones, Ischyropsalididae); Lithobius tylopus Latzel, 1882 (Chilopoda, Lithobiidae), Gryllomorpha dalmatina (Ocskay, 1832) (Orthoptera, Gryllidae), Hypaena sp. (Lepidoptera, Noctuidae), Stenophylax permistus McLachlan, 1895 (Tricoptera, Limnephilidae), and a large population of limoniid crane flies (Diptera, Limoniidae). Near the entrance and in the early section of the cave, numerous spiders were also observed: Amaurobius ferox (Walckenaer, 1830), A. pesarinii Ballarin and Pantini, 2017 (Amaurobiidae), Kryptonesticus eremita (Simon, 1880) (Nesticidae), Meta menardi (Latreille, 1804), Metellina merianae (Scopoli, 1763) (Tetragnathidae), Pholcus phalangioides (Fuesslin, 1775) (Pholcidae), and Tegenaria sp. (Agelenidae). The new species was found in the initial segments of the cave, but at some distance from the entrance (Fig. 3F). During summer, when the cave was visited, adults, subadults, and juveniles of $D$. culsu sp. nov. were observed together, with a substantially higher number of adults and subadults during the month of August. Most of the juveniles collected in the cave and bred in captivity became adults after 2-3 months of captivity, while it took approximately one year for the youngest specimens to reach sexual maturity. 


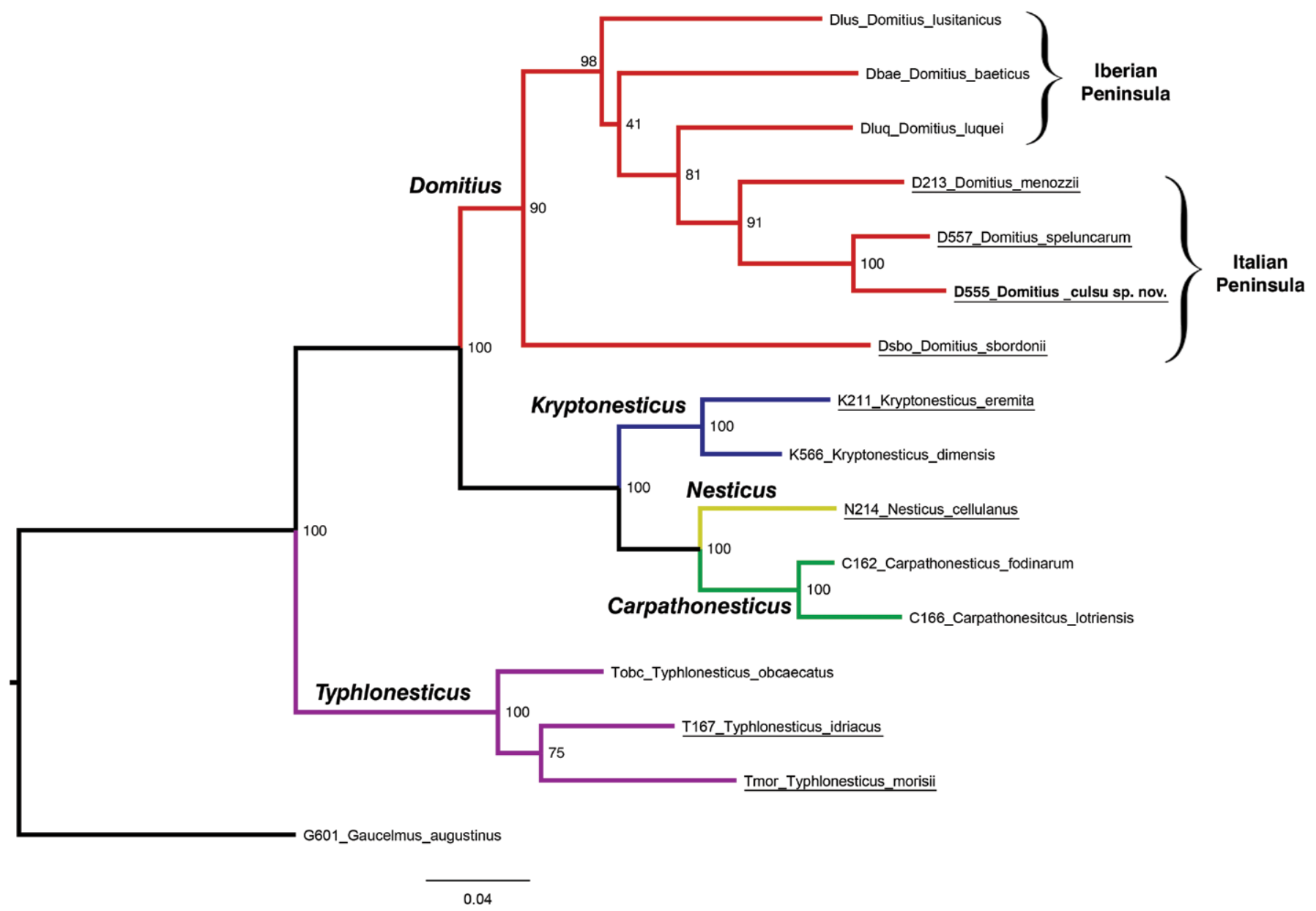

Figure 7. Phylogenetic tree of the main European nesticid genera inferred using ML in RAxML. Different colored branches reflect different genera: violet = Typhlonesticus, green = Carpathonesticus, yellow = Nesticus, blue = Kryptonesticus, red = Domitius. The newly-described species is highlighted in bold. Species distributed in Italy are underlined. Code before each species refers to the origin of the data, see Table 1. Branch lengths are scaled in relation to the number of substitutions per site; numbers at nodes denote bootstrap support according to ML.

Two different species of nesticid spiders, $K$. eremita and $D$. culsu sp. nov., were collected together in the Tana delle Fate di Coreglia Antelminelli cave. These species cover a different spatial distribution within the cave (Fig. 3F), coexisting without overlapping despite occupying approximately the same ecological niche. Cohabitant nesticids, in particular involving $D$. menozzii or $D$. speluncarum together with $K$. eremita, have been previously observed in several occasions in Italian caves, and sometimes collected at short distances from each other (Brignoli, 1971). However, no clear species overlap are reported within the same cave. Such distinct spatial partition can be explained by the different grade of adaptation to the hypogean environment showed by these arachnids. In fact, $K$. eremita appears to be a less specialized cave-dweller, lacking extreme morphological adaptations to subterranean life. Therefore, it mostly occurs near the entrance of caves or inside artificial tunnels, including, occasionally, shadowed epigean habitats with constant temperature and high relative humidity (Brignoli, 1971 and personal observations by the author). On the other hand, all Domitius species show a greater degree of adaptation to the subterranean habitat, as suggested by reduction of the eyes and body depigmentation. Such strong adaptation allows Domitius to occupy deeper segments of the caves, thus avoiding direct competition with $K$. eremita.

\section{Conservation Notes}

Since caves are a unique and delicate ecosystem, they are highly susceptible to external disturbance (Culver and Pipan, 2009). Its visible entrance and sub-horizontal extension makes Tana delle Fate di Coreglia Antelminelli cave easily accessible to visitors even with limited experience in speleology, and the cave is often used for training purposes by local speleological clubs. Although not threatened, $D$. culsu sp. nov. should be considered potentially at risk in case of frequent and long-lasting human disturbance due to its strict habitat requirements, its reduced population, and its extremely limited distribution, which appears to be confined to a single cave. Therefore, the new species is a good candidate for species conservation, deserving a place in the list of locally protected species. 


\section{Phylogenetic Analysis}

A total of 16 nesticid species were used in this study, including representatives of the main nesticid genera present in Europe and all the species distributed in the Italian peninsula. Taxon sampling comprised the wide majority of Domitius species. Only D. murgis (Ribera and De Mas, 2003) from Spain was excluded from the analysis due to the absence of available sequences and fresh samples. The final dataset was formed by 1975 pair bases (bp) distributed as; $\mathrm{COI}=$ $1197 \mathrm{bp}, 16 \mathrm{~S}=469 \mathrm{bp}$, and $\mathrm{H} 3=309 \mathrm{bp}$. The resulting phylogenetic tree is illustrated in Figure 7, and the uncorrected pairwise distance between the species is reported in Table 2. The European nesticids cluster into five different clades corresponding to the main genera Carpathonesticus, Domitius, Kryptonesticus, Nesticus, and Typhlonesticus, each of them highly supported (bootstrap support value $=100 \%$ ). Each lineage represents a different and well-defined evolutionary line. These results concur with the outcomes of recent morphological and phylogenetic studies on the family Nesticidae (Pavlek and Ribera, 2017; Ribera, 2018; Ballarin and Li, in prep.), supporting the validity of the newly-established genera. According to these results, Domitius represents the sister lineage of the monophyletic clade formed by the genera Carpathonesticus, Kryptonesticus, and Nesticus, with which it shares a common ancestor. The analysis supports Typhlonesticus as a basal clade within the European Nesticidae, as also suggested by recent molecular studies (Ballarin and Li, 2018; Ribera, 2018). Within Domitius, D. culsu sp. nov. shows a closer affinity with the species from the same geographic area; particularly $D$. speluncarum, but also $D$. menozzi. Its position at the far end of the phylogenetic tree of the genus suggests a more recent origin in comparison with the other congeneric species.

All the Domitius species distributed in the Northern Apennines share a close affinity with species from the Iberian Peninsula. Such close relations also reflected in genital morphology. For instance, all these species share a similar position of spermathecae, located in the lower-half of the vulva, and below the vulval pockets (see Figs. 1G, 5B, D and Figs. 4A-E in Ribera, 2018). On the other hand, D. sbordonii from the Central Apennines appears to be morphologically and genetically separated from all the other species of the genus, including those from Northern Apennines. The difference is highlighted in the peculiar shape of the vulva, being the only Domitius species showing simple-coiled internal ducts and spermathecae located in the upper-half of the vulva, over the vulval pockets (see Fig. 5F vs. Figs. 1G, 5B, D and Figs. 4A-E in Ribera, 2018). Upper-positioned spermathechae are also present in several other European nesticid genera such as Carpathonesticus (sensu stricto), Krypthonesticus, and Nesticus (sensu stricto). Based on these results

Table 2. Uncorrected genetic p-distance of the COI partial sequence of the nesticid species discussed in the text. The newly described species is in bold.

\begin{tabular}{|c|c|c|c|c|c|c|c|c|c|c|c|c|c|c|c|c|}
\hline No. & Species & 1 & 2 & 3 & 4 & 5 & 6 & 7 & 8 & 9 & 10 & 11 & 12 & 13 & 14 & 15 \\
\hline 1 & Dbae_Domitius_baeticus & & & & & & & & & & & & & & & \\
\hline 2 & Dluq_Domitius_luquei & 0.142 & & & & & & & & & & & & & & \\
\hline 3 & Dlus_Domitius_lusitanicus & 0.135 & 0.135 & & & & & & & & & & & & & \\
\hline 4 & D213_Domitius_menozzii & 0.140 & 0.146 & 0.119 & & & & & & & & & & & & \\
\hline 5 & $\begin{array}{l}\text { D555_Domitius_culsu sp. } \\
\text { nov. }\end{array}$ & 0.167 & 0.144 & 0.133 & 0.121 & & & & & & & & & & & \\
\hline 6 & Dsbo_Domitius_sbordonii & 0.181 & 0.176 & 0.167 & 0.181 & 0.185 & & & & & & & & & & \\
\hline 7 & $\begin{array}{l}\text { D557_Domitius_ } \\
\text { speluncarum }\end{array}$ & 0.162 & 0.144 & 0.121 & 0.121 & 0.071 & 0.190 & & & & & & & & & \\
\hline 8 & N214_Nesticus_cellulanus & 0.172 & 0.174 & 0.151 & 0.190 & 0.181 & 0.176 & 0.172 & & & & & & & & \\
\hline 9 & $\begin{array}{l}\text { K566_Kryptonesticus_ } \\
\text { dimensis }\end{array}$ & 0.156 & 0.151 & 0.135 & 0.144 & 0.165 & 0.172 & 0.146 & 0.121 & & & & & & & \\
\hline 10 & $\begin{array}{l}\text { K211_Kryptonesticus_ } \\
\text { eremita }\end{array}$ & 0.149 & 0.156 & 0.142 & 0.156 & 0.169 & 0.169 & 0.162 & 0.117 & 0.078 & & & & & & \\
\hline 11 & $\begin{array}{l}\text { C162_Carpathonesticus_ } \\
\text { fodinarum }\end{array}$ & 0.169 & 0.153 & 0.153 & 0.176 & 0.178 & 0.172 & 0.167 & 0.085 & 0.089 & 0.108 & & & & & \\
\hline 12 & $\begin{array}{l}\text { C166_Carpathonesitcus_ } \\
\text { lotriensis }\end{array}$ & 0.144 & 0.160 & 0.146 & 0.162 & 0.190 & 0.176 & 0.190 & 0.112 & 0.094 & 0.101 & 0.069 & & & & \\
\hline 13 & $\begin{array}{l}\text { Tobc_Typhlonesticus_ } \\
\text { obcaecatus }\end{array}$ & 0.197 & 0.178 & 0.167 & 0.165 & 0.178 & 0.176 & 0.181 & 0.149 & 0.156 & 0.158 & 0.140 & 0.142 & & & \\
\hline 14 & $\begin{array}{l}\text { T167_Typhlonesticus_- } \\
\text { idriacus }\end{array}$ & 0.181 & 0.174 & 0.167 & 0.183 & 0.192 & 0.197 & 0.185 & 0.142 & 0.156 & 0.165 & 0.149 & 0.156 & 0.096 & & \\
\hline 15 & $\begin{array}{l}\text { Tmor_Typhlonesticus_ } \\
\text { morisii }\end{array}$ & 0.174 & 0.174 & 0.174 & 0.181 & 0.199 & 0.208 & 0.181 & 0.183 & 0.160 & 0.183 & 0.176 & 0.174 & 0.117 & 0.124 & \\
\hline 16 & $\begin{array}{l}\text { G601_Gaucelmus_ } \\
\text { augustinus }\end{array}$ & 0.229 & 0.229 & 0.227 & 0.222 & 0.245 & 0.243 & 0.236 & 0.252 & 0.211 & 0.238 & 0.240 & 0.233 & 0.249 & 0.254 & 0.247 \\
\hline
\end{tabular}


it is possible to speculate that $D$. sbordonii represents a basal element within the genus Domitius, possibly still carrying the ancestral characters of the older forebear of the European nesticids.

\section{Conclusions}

All Italian species of the genus Domitius appear to be highly adapted to a permanent life in the subterranean environment, showing eye reduction and lack of body pigmentation. They further present a localized distribution, with distinct genetic and morphological differences between the species living in the Northern and Central areas of the Apennines. At the same time a close affinity with the species distributed in the Iberian Peninsula is observed. Such features, together with a high genetic $p$-distance among the species (Table 2), suggests a potentially complex evolutionary history of the genus Domitius that still needs to be properly explored (see also Ribera, 2018).

Because of their apparent similarities in habitus and female genitalia, $D$. culsu sp. nov has previously been mistaken for $D$. speluncarum and ignored as a distinct species by previous arachnologists. A detailed molecular and morphological analysis of both sexes of $D$. culsu sp. nov carried out in this work supports the validity of the new species and its close relationship with the other Domitius species from the same geographical area. Its potential susceptibility to external disturbance, and extremely limited distribution, makes $D$. culsu sp. nov of interest for conservation.

Finding a new nesticid species in Italy further suggests that our knowledge on the diversity of the family Nesticidae in Southern Europe is still far from complete. Further collections along the Italian peninsula will probably lead to the discovery of other highly-specialized nesticid species allowing a deeper and more precise understanding of the spider cave fauna in Italy and in the Mediterranean area.

\section{ACKNOWLEDGMENTS.}

Many thanks to Leonardo Latella and Roberta Salmaso for providing the use of microscopes and other facilities at the Natural History Museum of Verona, and for taking care of the juvenile samples under study. Thanks to Shuqiang $\mathrm{Li}$ (Chinese Academy of Sciences, Beijing) for supporting the molecular analysis of the samples, and to Domenico Rutigliano for his suggestions in choosing the name of the species. I am particularly grateful to Daniele Avesani for his important help in the field, which eventually led to the collection of the holotype male. I am equally thankful to all the people who kindly contributed in the field collection of the samples, or provided useful data and advice during the preparation of the article: Rodolfo Ballarin, Roberto Battiston, Manuele Gaiga, Giulio Gardini, Kadir B. Kunt, Augustin Nae, Paolo Pantini, Leonardo Piccini, Sara Pesenato, Antonio Scupola, Stefano Taiti, Alessio Trotta, Marco Valle, Stefano Vanni, and Simone Zannotti. Elena Ballarin kindly prepared the drawings used in the article. The English text of an early version of the work was edited by Victoria Smith (Canterbury Museum, New Zealand). I thank the three anonymous reviewers whose comments have helped to improve the manuscript. This work was supported by the "Prof. Sandro Ruffo" grant, Municipality of Verona. Molecular analysis of the samples was supported by the National Natural Sciences Foundation of China (NSFC- 31530067).

\section{References}

Ballarin, F., and Li, S., 2018, Diversification in tropics and subtropics following the mid-Miocene climate change: A case study of the spider genus Nesticella: Global Change Biology, v. 24, p. 577-591, doi: 10.1111/gcb.13958.

Brignoli, P.M., 1971, Note su ragni cavernicoli italiani (Araneae): Fragmenta Entomologica, p. 121-229.

Brignoli, P.M., 1979, Ragni d'Italia XXXI. Specie cavernicole nuove o interessanti (Araneae):. Quaderni del Museo di Speleologia “V. Rivera”, v. 5, no. 10, p. 1-48.

Brignoli, P.M., 1985, Aggiunte e correzioni al "Catalogo dei ragni cavernicoli italiani”: Memorie del Museo Civico di Storia Naturale di Verona, serie 2, v. 4, p. 51-64.

Culver D.C., and Pipan T., 2009, The Biology of Caves and Other Subterranean Habitats: Oxford, UK: Oxford University Press, p. 256.

Dresco, E., 1966, Étude de quelques espèces d'araignées du genre Nesticus (fam. Nesticidae): Annales de Spéléologie, v. 21, p. 795-813.

GenBank, 2018, GenBank sequence database: Available at: https://www.ncbi.nlm.nih.gov/genbank/, [accessed August, 2018].

Hall, T., 1999, BioEdit: a user friendly biological sequence alignment editor and analysis program for Windows 95/98/NT: Nucleic Acids Symposium Series, v. 41, p. 95-98.

Katoh, K., and Standley, D.M., 2013, MAFFT multiple sequence alignment software version 7: improvements in performance and usability: Molecular Biology and Evolution, v. 30, p. 772-780, https://doi.org/10.1093/molbev/mst010.

Kritscher, E., 1958, Araneen aus den Picentinischen Bergen: Memorie del Museo Civico di Storia Naturale di Verona, v. 6, p. 313-320.

Lanza, B, 1961, La fauna cavernicola della Toscana: Rassegna Speleologica Italiana, v. 13, no. 2, p. 23-51.

Lin, Y.C., Ballarin, F. and Li, S.Q., 2016, A survey of the spider family Nesticidae (Arachnida, Araneae) in Asia and Madagascar, with the description of forty-three new species: ZooKeys v. 627, p. 1-168. https://doi.org/10.3897/zookeys.627.8629

Mammola, S., and Isaia, M., 2017, Spiders in caves: Proceedings of the Royal Society B: Biological Sciences, v. 284: 20170193, https://doi. org/10.1098/rspb.2017.0193.

Miller, M.A., Pfeiffer, W., and Schwartz, T., 2010, Creating the CIPRES Science Gateway for inference of large phylogenetic trees: Proceedings of the Gateway Computing Environments Workshop (GCE), 14 Nov. 2010, New Orleans, LA, p. 1-8, https://doi.org/10.1109/ GCE.2010.5676129.

Pantini P. \& Isaia M. 2019. Araneae.it: the online Catalog of Italian spiders with addenda on other Arachnid Orders occurring in Italy (Arachnida: Araneae, Opiliones, Palpigradi, Pseudoscorpionida, Scorpiones, Solifugae). Fragmenta Entomologica 51 (2): 127-152. Available on line at www.araneae.it [accessed February 2020]. https://doi.org/10.4081/fe.2019.374. 
Pavlek, M., and Ribera, C. 2017, Kryptonesticus deelemanae gen. et sp. nov. (Araneae, Nesticidae), with notes on the Mediterranean cave species: European Journal of Taxonomy, 262, p. 1-27, https://doi.org/10.5852/ejt.2017.262.

Ribera, C., 2018, A new genus of nesticid spiders from western European Peninsulas (Araneae, Nesticidae): Zootaxa, v. 4407, p. 229-240, https://doi.org/10.11646/zootaxa.4407.2.4.

Stamatakis, A., 2014, RAxML version 8: a tool for phylogenetic analysis and post-analysis of large phylogenies: Bioinformatics, v. 30 , p. 1312-1313, https://doi.org/10.1093/bioinformatics/btu033.

Tamura, K., Stecher, G., Peterson, D., Filipski, A., and Kumar, S., 2013, MEGA6: Molecular Evolutionary Genetics Analysis version 6.0: Molecular Biology and Evolution, v. 30, p. 2725-2729, https://doi.org/10.1093/molbev/mst197,

World Spider Catalog, 2020, World Spider Catalog. Version 21.0: Natural History Museum Bern, available at: http://wsc.nmbe.ch, [accessed February, 2020], doi: 10.24436/2.

Zangheri, P., 1966, Repertorio sistematico e topografico della flora e fauna vivente e fossile della Romagna, Tomo II - Regno Animale. Museo Civico di Storia Naturale di Verona: Memorie Fuori Serie n¹, Stamperia Valdonega, Verona, p. 854 
L. M. Kondratyeva, O. S. Shadrina, Z. N. Litvinenko, and E. M. Golubeva. Biogeochemical investigations of the speleothem moonmilk in the karst Proschalnaya Cave (Far East, Russia). Journal of Cave and Karst Studies, v. 82, no. 2, p. 95-105. DOI:10.4311/2019MB0106

\title{
BIOGEOCHEMICAL INVESTIGATIONS OF THE SPELEOTHEM MOONMILK IN THE KARST PROSCHALNAYA CAVE (FAR EAST, RUSSIA)
}

\author{
L. M. Kondratyeva', O. S. Shadrina', Z. N. Litvinenko ${ }^{1, C}$, and E. M. Golubeva ${ }^{2}$
}

\section{Abstract}

Results of investigations of natural waters (drip and fracture) and speleothem moonmilk from the karst Proschalnaya Cave (Russia, Far East) are reported. Concentrations of Fe and Mn in drip water were highest in spring, while the concentration of $\mathrm{Mn}$ was lowest in the fracture water, which may be due to the nature of infiltration of water through different channels after spring snowmelt and autumn rains. Molecular genetics investigation of the moonmilk mass revealed the presence of iron bacteria of the genera Rhodoferax and Geothrix. The visually plastic and homogeneous mass of moonmilk was shown to be highly heterogeneous, containing various microstructures. Tubular microstructures had a richer elemental composition ( $\mathrm{C}, \mathrm{O}, \mathrm{Ca}, \mathrm{Fe}, \mathrm{Mn}, \mathrm{Si}, \mathrm{Al}$, and $\mathrm{S}$ ), in comparison with claviform formations $(\mathrm{C}, \mathrm{O}, \mathrm{Ca}$, and $\mathrm{Na}$ ). Binding matrix in the composition of moonmilk is represented by reticular structures similar to nanofibers. The results of this research conducted in a monsoon climate may be interesting for speleologists working with karst caves in other climatic conditions.

\section{Introduction}

Microbes present in the specific habitats of aquifers and pore space of rocks play an important role in the processes occurring in the water-rock contact zone (Perry et al., 2004). Various organic compounds and microorganisms that are capable of colonizing the surface of rocks enter karst caves from the ground biotopes with infiltration waters (Chelius et al., 2009). However, the cave microbial composition varies by the types and configuration of caves (Barton et al., 2004; Velikonja et al., 2014) and depends on the sampling location (Ghosh et al., 2017).

As the results of analysis of microbial communities sampled from the walls of caves located in Spain, Czech Republic, and Slovenia, Porca et al., (2012) proposed the hypothesis that the colonization of caves with microorganisms occurred through water infiltration from the overlying rock and soil. The heterogeneity and main mechanism of microbial diversity in caves are well-connected with surface environments (Wu et al., 2015). Microbial exopolysaccharides, alginate acids, siderophores, and other chelating compounds act as important factors determining the colonization and dissolution rate of mineral rocks (Perry et al., 2004; Ercole et al., 2007; Kuhn et al., 2014).

Alternatively, microbial cells have been shown to act as centers for precipitation and crystallization of many elements (Barton and Northup, 2007). Microorganisms are also capable of altering the mineral composition and solubility of carbonates, as well as crystal size and morphology, as demonstrated by the large, poorly soluble $\mathrm{CaCO}_{3}$ crystals formed in the presence of Bacillus pasteurii (Mitchell and Ferris, 2006).

Dissolution of carbonate minerals and morphogenesis of karst cavities may be partially explained by bacterial activity (Hill and Forti, 2007). Infiltration, flood water, and airflow also introduce microbes into caves, where they can begin to influence the structure of the microbial community of caves. As weather parameters and water conditions change, the introduced microbial pool may also change strongly. As in surface environments, microorganisms act as active and passive promoters of redox reactions in the sedimentary processes in caves (dissolution, redeposition, secondary formation of minerals with participation of microorganisms) (Fornós et al., 2014).

The investigation of karst caves is presently carried out in several fields, including speleology, geology, and ecology. Research varies from large-scale analyses of landforms and processes involved in the formation of karst landscapes, to speleothems, including stalactites and stalagmites, to microscopic investigation of sinter formations. Among speleothems, moonmilk is a formation of high interest (Borsato et al., 2000; Cacchio et al., 2014). Moonmilk, one of the most common types of carbonate deposits (speleothems) formed in caves, has long been known as a habitat for microorganisms that are thought to be responsible for the origin of these commonly white and soft secondary calcite deposits (Reitschuler et al., 2016). Various forms of moonmilk deposition have been described, including encrustations, films, thick layers, deposits, and veins in clay. The metabolic activity of complex microbial communities can play an important role in the formation of moonmilk (Portillo and Gonzales, 2011).

The presence of microorganisms in moonmilk formations has been observed in caves around the world, from the tropics to high latitudes. It has been found that microbes participate in formation of the white and soft secondary calcite (calcium carbonate) deposits that can coat the walls, floors, and ceilings of caves. In this biologically-driven process,

\footnotetext{
${ }^{1}$ Institute of Water and Ecology Problems, Far Eastern Branch, Russian Academy of Sciences, Khabarovsk, 680000 Russia

${ }^{2}$ Institute of Tectonics and Geophysics, Far Eastern Branch, Russian Academy of Sciences, Khabarovsk, 680000 Russia

cCorresponding Author: zoyalitvinenko@gmail.com
} 
upper surface layers are actively formed, while the deeper and older parts become progressively dehydrated, encrusted, and inactive (Canaveras et al., 2006).

Moonmilk is primarily water by mass (60-90\%). In this geochemical environment, microbial cells can act as centers of precipitation and crystallization for many elements (Barton and Northup, 2007). As $90 \%$ of Earth's biomass resides in the subsurface, and many of those environments are exposed to constantly cold conditions (below $5{ }^{\circ} \mathrm{C}$ ), basic research on exotic habitats such as moonmilk through cultivation of microorganisms and geochemical analyses is important for understanding potentially widespread processes (Rodrigues and Tiedje, 2008). Low-temperature biotopes are successfully colonized by cold-adapted organisms, which include a large range of representatives from all three domains: Bacteria, Archaea, and Eukarya. As a result, psychrophiles are the most abundant in terms of biomass, diversity, and distribution (Struvay and Feller, 2012). The ability of psychrophilic microorganisms to grow at temperatures below $5{ }^{\circ} \mathrm{C}$ can be associated with their successful adaptation to the natural habitat. It is known that the microbial activity of psychrophiles and growth yield at low temperatures is higher than the growth rate at what is normally considered the optimal growth temperature (Margesin, 2009).

Microorganisms utilize several metabolic strategies to survive in the cave environment, such as synthesis of new organic matter from inorganic carbon (chemolithoautotrophy) and decomposition of organic matter (heterotrophy) (Chen et al., 2009). These processes, or its byproducts, can play a role in the transformation of rock through dissolution or formation of minerals (Lefevre et al., 2016).

Based on past studies conducted in the Snezhnaya Cave (Abkhazia) (Kondratyeva et al., 2016), it was hypothesized that the elemental composition of groundwater and the structure of microbial communities play a key role in determining the elemental composition of the moonmilk. Our research is devoted to the study of the elemental composition of groundwater and moonmilk, as well as the activity of microorganisms in the Proschalnaya Cave (Far East, Russia).

Investigation of moonmilk from Proschalnaya Cave was conducted in two stages: (1) microbiological research (molecular genetic techniques, isolation of cultured bacterial strains, determination of their physiological and biochemical activity) and (2) the analysis of nanostructures in the moonmilk mass by scanning electron microscopy with determination of their elemental composition.

The main objective of our research was to determine environmental factors that characterized pecularities of biofilm from moonmilk in a large karst cave on the Far East of Russia. For the first time interdisciplinary studies including physicochemical, microbiological, molecular genetic methods, and scanning electron microscopy of moonmilk from the Proshalnaya Cave were conducted. The results of research on biofilm and rock interactions in a monsoonal climate can be interesting for speleologists working with karst caves in other climatic conditions.

\section{Materials and Methods}

\section{Sampling site}

Proschalnaya Cave is on the eastern slope of the Sagdi-Selanka River valley (Amur River Basin) in the Khabarovsk

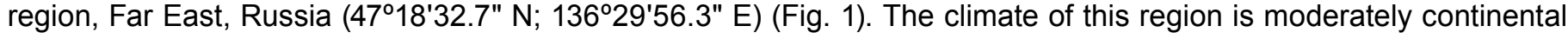
with signs of monsoonal: humid summers with frequent rains and winter with little snow. A monsoonal climate is characterized by a sharp contrast in the amount of precipitation over the year seasons and stability of the wind direction for one season with a sharp wind variation in the opposite direction during changing seasons. The cave is remote from settlements, not visited by tourists, and accessible for speleologists only. The cave does not have access for animals due to the complex labyrinths and deep depth.

The cave is a labyrinth with a total length of approximately $6 \mathrm{~km}$, multiple levels, and a large number of halls, galleries, and grottos. There is a watercourse and many sources of drip and fracture water inside the cave; the walls and ceilings are covered with various speleothems, including moonmilk (Fig. 2). The chemical composition of the karst waters of the Russian Far East are primarily hydrocarbonate-calcium , and more rarely, chloride-hydrocarbonate-calcium with an average degree of mineralization (5-15 g/L) (Bersenyov, 1989). Surface waters of the Sagdi-Selanka River and groundwaters of Proschalnaya Cave are characterized by an increased content of Ca ions (82-86 \% mg-Eq) and a very low concentration of $\mathrm{Mg}$ ions (9-12\% mg-Eq) (Shesterkin, 1983). Hydrochemical studies of natural waters in the Proschalnaya Cave have not been carried out in recent years.

\section{Sampling characterization}

In May 2015, 2016, and 2017 and in November 2015, water samples of different origins were taken from the cave (watercourse, drip, and fracture water) and from the Sagdi-Selanka River (surface water) according to the standards of sampling in hydrochemistry and microbiology (Gerhardt, 1983; Kuznetsov and Dubinina, 1989). In the study area, the average amount of precipitation during the month was: $105 \mathrm{~mm}$ in May 2015; $136 \mathrm{~mm}$ in May 2016, and $48 \mathrm{~mm}$ in May 2017. In November 2015, precipitation was minimum, $9.9 \mathrm{~mm}$. In the cave air temperature was $1-4{ }^{\circ} \mathrm{C}$. 


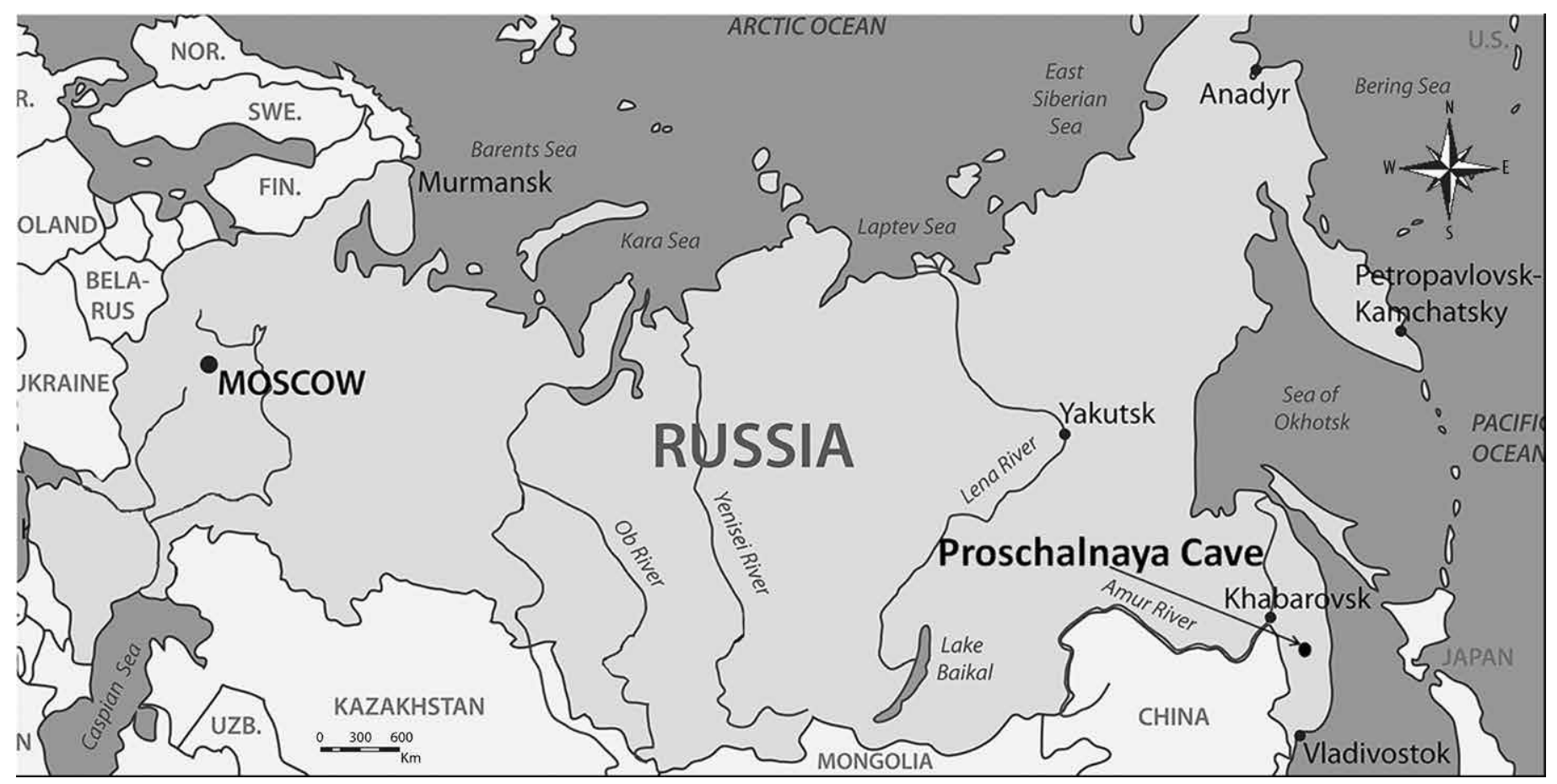

Figure. 1. Geographical location of the Proschalnaya Cave in the Amur River Basin, Khabarovsk region (Far East, Russia).
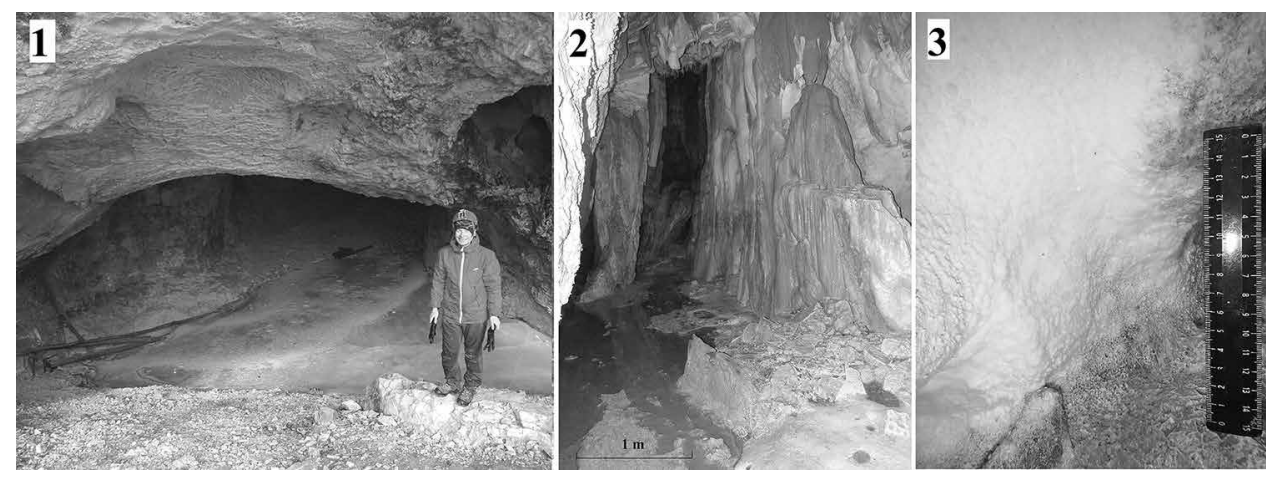

Figure. 2. Proschalnaya Cave (Russia): (1) Entrance to the cave, (2) Gallery in the Albatross system, (3) moonmilk on the wall (M2 - thick curdy ivory-white mass).
In the Marble room, samples of moonmilk deposits of different consistencies were aseptically collected in sterile tubes: M1thin slimy white mass and M2thick curdy ivory-white mass were taken from the walls; M3-dry white mass was taken from the surface of broken rocks. Samples were transported to the laboratory in coolers at $4{ }^{\circ} \mathrm{C}$.

Determination of the elemental composition in samples of natural waters and moonmilk was carried out with use of the Total Quant out with use of the

ICP-MS method, PerkinEImer (USA), in accordance with standard methods (Federation Regulation, 2011).

\section{Microbial studies}

For the inoculum, $100 \mathrm{mg}$ of wet mass of moonmilk was dispersed in $10 \mathrm{~mL}$ of sterile physiological saline; dilution was performed in 100 -fold and $0.1 \mathrm{~mL}$ of suspension was used for spread-plating on the agar culture media. The abundance of heterotrophic and Fe-metabolizing cultivated bacteria (CFU/mL) in natural waters and in moonmilk was determined on the 7 th day after cultivation on solid nutrient media with use of spread plates at $23^{\circ} \mathrm{C}$ : SAA (starch ammonium agar) (Gerhardt, 1983); FPA (fish peptone agar) and FPA diluted 10 times (Kuznetsov and Dubinina, 1989); and Vinogradsky medium (Egorov, 1995). For the cultivation of Fe-metabolizing bacteria, Bromfield agar medium was used (Namsaraev et al., 2006).

Diagnostic system (SPA Microgen, Moscow, Russia) with color indicators and various carbon sources (carbohydrates, polyhydric alcohols, and amino acids) was used to determine the nutritional range of strains isolated from different types of water. The growth activity of the strains was evaluated by the color change of the dissolved substrate on the 7 th day after cultivation at $23^{\circ} \mathrm{C}$. Amylase activity was determined on SAA after treating the colonies with Lugol's solution according to the diameter of the starch hydrolysis zones. 


\section{qPCR analysis}

Microbial investigation of moonmilk samples (M1 and M2) were carried out with use of quantitative PCR (qPCR) analysis according to standard procedures (Kubista et al., 2006). DNA was extracted using a GeneMATRIX Soil DNA Purification Kit (Roboklon, Berlin, Germany). The total number of eubacterial DNA copies and the DNA copies of bacteria of the genera Rhodoferax and Geothrix were determined with use of specialized primers which were offered by Prof. U. Szewzyk (Technische Universität Berlin): Eubacteria (Uni338F_RC ACT CCT ACG GGA GGC AGC, Uni907R CCG TCA ATT CMT TTG AGT TT); Rhodoferax ferrireducens group (RdoR_RC GAC CTG CAT TTG TGA CTG YA, Uni907R CCG TCA ATT CMT TTG AGT TT), Geothrix (Gx. 193F_GAC CTT CGG CTG GGA TGC TG, Gx. 448R_AGT CGT GCC ACC TTC GT) (Braun et al., 2016). Quantitative PCR was performed with an RG-6000-5 Plex real-time DNA cycler (Rotor-Gene 6000). Non-DNA-containing samples were used as negative controls to ensure the accuracy of the qPCR. Cycles of qPCR characterized: 40 cycles for Eubacteria (Initial denaturation $95^{\circ} \mathrm{C}, 2$ min; Denaturation $95^{\circ} \mathrm{C}$, $20 \mathrm{~s}$; Annealing $60.4^{\circ} \mathrm{C} 30 \mathrm{~s}$; Extension $72^{\circ} \mathrm{C}, 1 \mathrm{~min}$ ); 40 cycles for Rhodoferax ferrireducens (Initial denaturation 95 ${ }^{\circ} \mathrm{C}, 2 \mathrm{~min}$; Denaturation $95^{\circ} \mathrm{C}, 20 \mathrm{~s}$; Annealing $58^{\circ} \mathrm{C}, 30 \mathrm{~s}$; Extension $72{ }^{\circ} \mathrm{C}, 1 \mathrm{~min}$ ); 45 cycles for Geothrix fermentans (Initial denaturation $95^{\circ} \mathrm{C}, 3 \mathrm{~min}$; Denaturation $95^{\circ} \mathrm{C} 20 \mathrm{~s}$; Annealing $58^{\circ} \mathrm{C}, 20 \mathrm{~s}$; Extension $72{ }^{\circ} \mathrm{C}, 30 \mathrm{~s}$ ). Quantification was performed using standard curves obtained from the amplification profiles of known concentrations of the respective standard. A melt curve analysis $\left(55-99^{\circ} \mathrm{C}\right)$ was performed at the end of PCR cycles to confirm specificity of primer annealing. The parameters for the calibration curves were $R^{2}>0.99$, efficiency from $92 \%$ to $98 \%$.

\section{Scanning electron microscopy}

Textural and microstructural characterization of moonmilk was performed using a VEGA 3 LMH TESCAN scanning electron microscope (Czech Republic). The samples were prepared by air drying, and Pt coating. Then the moonmilk samples were placed on a conductive carbon tape, mounted on $12 \mathrm{~mm}$ diameter aluminum stubs that were then placed in the microscope chamber; magnification was up to 15,000x. Energy dispersive spectrometer X-max 80 with Aztec $^{\mathrm{TM}}$ microanalysis system (Oxford Instruments, UK) was used for the elemental composition analysis of moonmilk. X-Max 80 provides a range of detected elements from boron to uranium with elements detection interval from 0.1-100 wt. \%. The general process for sample preparation and scanning electron microscopy were carried out at the Khabarovsk Innovation and Analytical Center for Collective Use at the Institute of Tectonics and Geophysics, Far East Branch, Russian Academy of Science.

\section{Results and Discussion}

\section{Elemental composition of water of different origins}

The content of $\mathrm{Ca}$ in drip and fracture water in the Proschalnaya Cave is dependent on the amount of precipitation. The maximum amount of $\mathrm{Ca}$ in drip and fracture water was recorded in May 2016 (Fig. 3) at maximum amount of precipitation (136 mm/month). High Ca content is associated with dissolution of calcium carbonates contained in rocks in interaction with natural waters, especially when the acidity of the water increases in the presence of organic matter (OM) and microbial metabolic activities in the overlying soils.

We have shown (Kondratyeva et al., 2016) that in vitro the process of dissolution of $\mathrm{CaCO}_{3}$ crystals was accelerated in the presence of nitrogen-containing OM. Microorganisms capable of synthesizing a polymer matrix played a determinative role. The formation of abundant slimy biofilms that formed on the surface of $\mathrm{CaCO}_{3} \mathrm{crystals}_{\text {contributed to }}$ their dissolution (Fig. 4). During cultivation of moonmilk suspensions on agar nutrient media, we often observed growth of slimy colonies of heterotrophic bacteria capable of consuming different sources of carbon. The polymer matrix produced by these bacteria may be an active accumulator of other elements forming the moonmilk mass. It is known that over $99 \%$ of microorganisms on Earth live within matrix consisting of a mixture of polymeric compounds (extracellular polymeric substance: EPS), which makes up the intercellular space of microbial aggregates and forms the structure and architecture of the biofilm matrix (Flemming, 2016).

$\mathrm{Fe}$ and $\mathrm{Mn}$ measurements for drip water were highest in the spring period. Enrichment of water with iron occurs as a result of leaching and dissolution of ferruginous minerals and rocks. Among the geochemical factors, ferric oxide was correlated with increased microbial diversity in the cave sediments (De Mandal et al., 2017). It should be noted seasonal asynchrony in the content of manganese in the drip and fracture water in the Proschalnaya Cave. In November 2015, the content of $\mathrm{Mn}$ in the fracture water was much higher than in the drip water and watercourses. In the spring of 2016, the concentration of manganese in the fracture water was lower than in other water samples, which may be due to the infiltration of water through different channels after spring snowmelt and autumn rains. Organic substances play an important role in determining the intensity of microbiological processes at the biogeochemical barrier of water-rock, which would also affect the content of dissolved forms of iron and manganese (Ferris, 2005). 
Ca

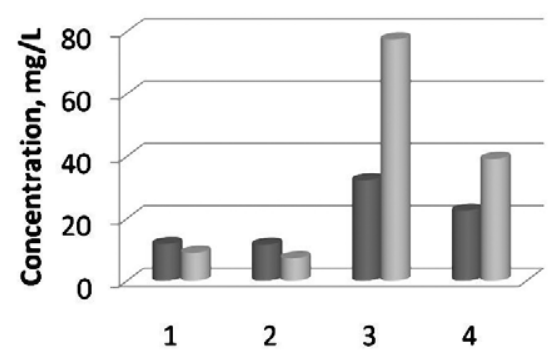

$\mathrm{Fe}$

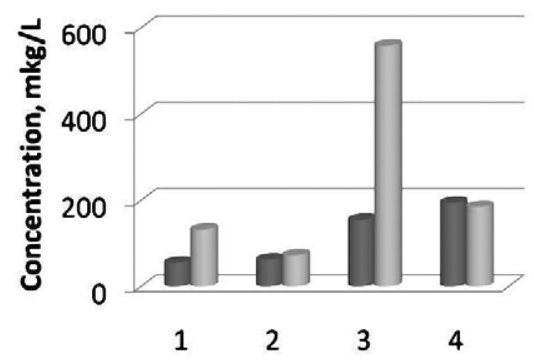

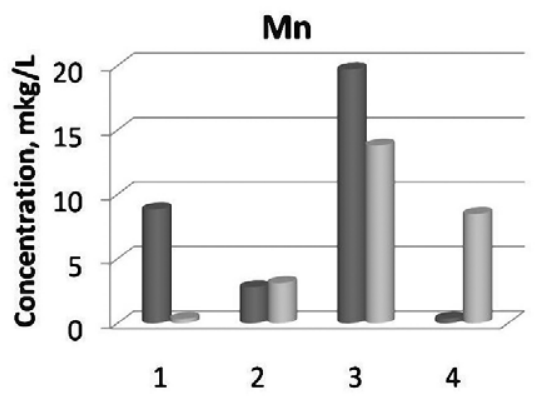

November, 2015 May, 2016

Figure. 3. The content of calcium, iron, and manganese in natural waters of different origins (November 2015; May 2016): (1) watercourse from the Proschalnaya Cave; (2) surface water from Sagdi-Selanka River; (3) drip water; (4) fracture water.

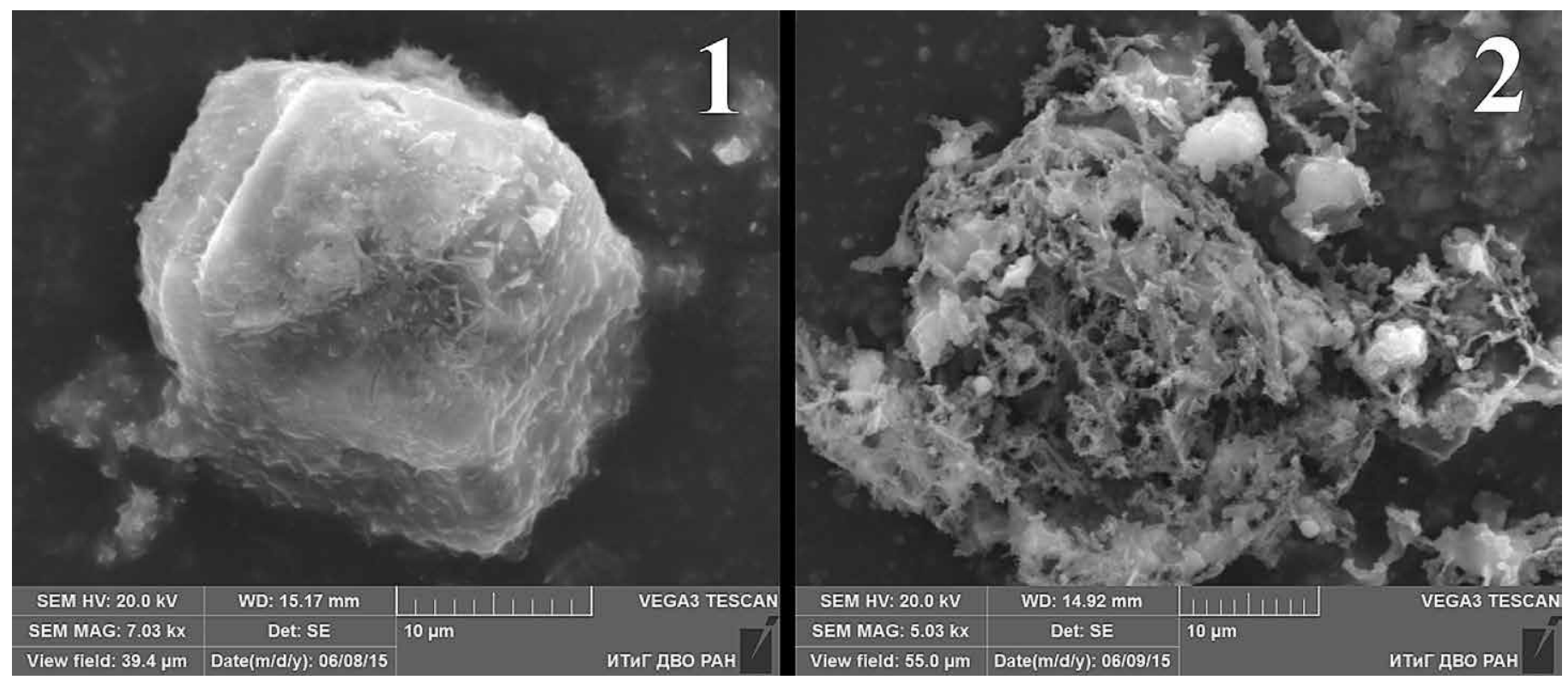

Figure. 4. SEM image of different stages of $\mathrm{CaCO}_{3}$ crystal dissolution: (1) stage of bacterial cells adhesion and the formation of EPS on the surface of the $\mathrm{CaCO}_{3}$ crystal; (2) final stage of complete dissolution of the crystal; formed biofilms retain the shape of the crystal in space.

\section{Microbiological studies of water}

In samples of water from the watercourse in the Proschalnaya Cave, regardless of the season, the predominant microorganisms preferred low concentrations of OM. Nitrifying and ferromanganese bacteria were also present in these samples. The most abundant microorganisms $\left(6.28 \times 10^{3} \mathrm{CFU} / \mathrm{mL}\right)$ were in the cave watercourse in the spring, likely due to the increased transport of easily oxidized OM from the soil during snowmelt. During this time, the number of microorganisms present in the samples of surface water from Sagdi-Selanka River was lower due to increased flow velocity and volume. Autumn sampling from the cave watercourse and river surface water revealed decreased numbers of all physiological groups of cultivated microorganisms.

Fifty strains were isolated from water samples on different media (FPA; FPA diluted 10 times; Vinogradsky media). Using cultural and morphological characteristics, ten strains with active growth on agar media were selected for the study of biochemical activity. Strains isolated from the surface water of Sagdi-Selanka River and fracture water were most active and capable of utilizing the monosaccharides $\beta$-galactose, glucose, mannose, arabinose, arginine, ornithine, and mannitol as a source of carbon (Table 1). Strains of bacteria isolated from the river surface water and watercourse in the cave recycled the disaccharides lactose and sucrose, associated with the enzyme carbohydrase, which is responsible for the hydrolysis of di-, tri-, and polysaccharides. This enzyme also plays a role in regulating equilibrium between different forms of inorganic carbon, including bicarbonate, which is involved in the precipitation of calcium in nature (Müller et al., 2014).

Some strains isolated from fracture water and one representative of drip water utilized various amino acids (arginine, lysine, and ornithine) as a carbon source. Strains from the cave watercourse and fracture water actively utilized alco- 
Table 1. Carbon utilization by the strains isolated from surface water of Sagdi-Selanka River and different water sources from the Proschalnaya Cave (May, 2017).

\begin{tabular}{|c|c|c|c|c|c|c|c|c|c|c|}
\hline \multirow[b]{3}{*}{ Source of Carbon } & \multicolumn{10}{|c|}{ Bacterial Strain per Water Source } \\
\hline & \multicolumn{3}{|c|}{$\begin{array}{l}\text { Surface water from } \\
\text { Sagdi-Selanka River }\end{array}$} & \multicolumn{2}{|c|}{$\begin{array}{c}\text { Watercourse } \\
\text { in Cave }\end{array}$} & \multicolumn{3}{|c|}{$\begin{array}{l}\text { Drip Water } \\
\text { in Cave }\end{array}$} & \multicolumn{2}{|c|}{$\begin{array}{c}\text { Fracture } \\
\text { Water } \\
\text { in Cave }\end{array}$} \\
\hline & B 44 & B 45 & B 46 & B 19 & B 21 & B 25 & B 26 & B 32 & B 38 & B 42 \\
\hline Glucose & + & + & + & + & + & + & - & + & + & + \\
\hline Mannose & + & + & + & + & + & + & + & + & + & + \\
\hline Arabinose & + & + & + & + & + & + & + & + & + & + \\
\hline Lactose & + & - & + & + & - & + & + & + & + & - \\
\hline Sucrose & + & - & - & + & - & + & - & - & + & - \\
\hline Arginine & + & + & + & + & + & + & + & + & + & + \\
\hline Lysine & - & - & - & - & - & + & - & - & + & + \\
\hline Ornithine & + & + & + & + & + & + & + & + & + & + \\
\hline Inositol & + & - & + & + & + & + & - & + & + & + \\
\hline Mannitol & + & - & + & + & + & - & + & + & + & + \\
\hline Sorbitol & - & - & + & + & + & + & + & + & + & + \\
\hline$\beta$-galactose & + & + & - & - & - & - & - & - & - & + \\
\hline Sodium malonate & + & - & + & + & + & + & + & + & + & + \\
\hline Sodium citrate & + & - & + & + & + & + & + & + & + & + \\
\hline Urea & - & - & + & - & + & + & - & + & - & + \\
\hline
\end{tabular}

Note: "+" is a positive reaction, "-“ is a negative reaction.

hols (inositol, sorbitol, and mannitol). Most strains were also capable of using citrates as a source of carbon. Overall, strains isolated from fracture water had the most flexible carbon requirements.

\section{Microbiological studies of the moonmilk}

The abundance of cultivated bacteria within moonmilk varies strongly depending on its consistency (Table 2). In all samples, heterotrophic microorganisms dominated, consuming high concentrations of nitrogen-containing organic

Table 2. Structures of the microbial communities of moonmilk of different consistency from the Proschalnaya Cave.

\begin{tabular}{|c|c|c|c|c|}
\hline \multirow[b]{2}{*}{ Media } & \multirow[b]{2}{*}{ Colony Morphotype } & \multicolumn{3}{|c|}{ Abundance of microorganisms, CFU/g $\times 1000$} \\
\hline & & $\begin{array}{c}\text { Sample No. M1 } \\
\text { (thin slimy white mass) }\end{array}$ & $\begin{array}{c}\text { Sample No. M2 } \\
\text { (thick curdy ivory-white mass) }\end{array}$ & $\begin{array}{l}\text { Sample No. M3 } \\
\text { (dry white mass) }\end{array}$ \\
\hline \multirow[t]{4}{*}{ FPA } & PR & $111 \pm 10.5$ & $142 \pm 16.8$ & $15 \pm 3.9$ \\
\hline & $\mathrm{PO}$ & $41 \pm 6.4$ & $5 \pm 2.2$ & $3 \pm 0.7$ \\
\hline & Y & $74 \pm 8.6$ & $3 \pm 0.7$ & $\cdots$ \\
\hline & Total & $226 \pm 25.5$ & $150 \pm 12.7$ & $18 \pm 4.6$ \\
\hline \multirow[t]{6}{*}{ FPA:10 } & ST & $74 \pm 8.6$ & $\cdots$ & $\cdots$ \\
\hline & $\mathrm{OA}$ & $32 \pm 5.6$ & $\cdots$ & $5 \pm 2.2$ \\
\hline & $\mathrm{B}$ & $2 \pm 0.4$ & $\cdots$ & $\cdots$ \\
\hline & G & $\cdots$ & $6 \pm 1.4$ & $22 \pm 4.7$ \\
\hline & MM & $\cdots$ & $86 \pm 9.3$ & $\cdots$ \\
\hline & Total & $108 \pm 14.6$ & $92 \pm 10.7$ & $27 \pm 6.9$ \\
\hline \multirow[t]{3}{*}{ SAA } & os & $70 \pm 8.4$ & $\ldots$ & $\mathrm{n} / \mathrm{a}$ \\
\hline & OSp & $22 \pm 4.7$ & $52 \pm 5.2$ & $\mathrm{n} / \mathrm{a}$ \\
\hline & Total & $92 \pm 13.1$ & $52 \pm 5.2$ & $\mathrm{n} / \mathrm{a}$ \\
\hline
\end{tabular}

Note: Colony Morphotype: PR: Pale-yellow, rugose; PO: Pale-yellow, oily; Y: yellow; ST: slimy, translucent; OA: opaline, asterial; B: brown; G: grey; OS: opaline, slimy; OO: opaline, oily; OSp: opaline, spot, "..." no colonies of this morphotype, "n/a" not available. 


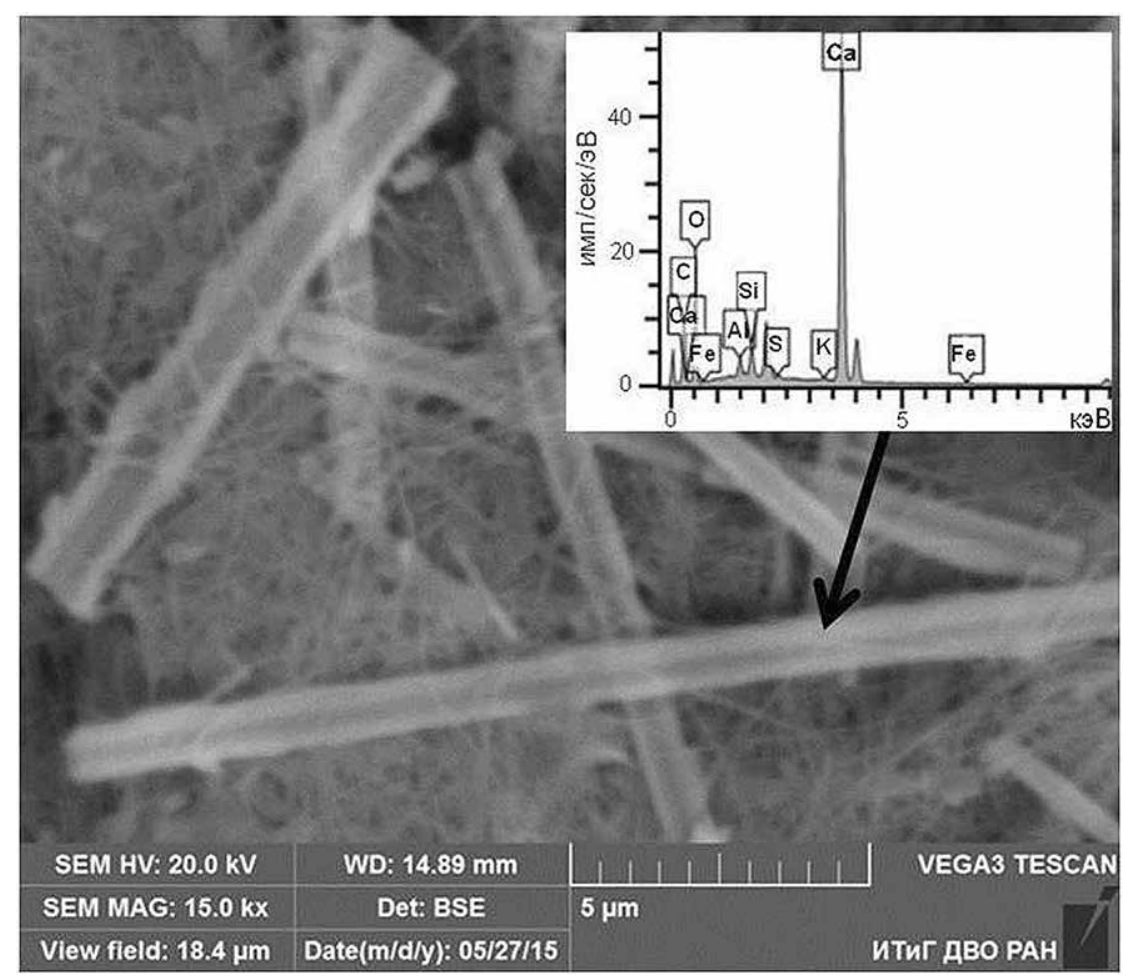

Figure. 5. SEM image and elemental composition of tubular microstructures in the composition of moonmilk, immersed in a mesh matrix. Magnification: 15,000x.

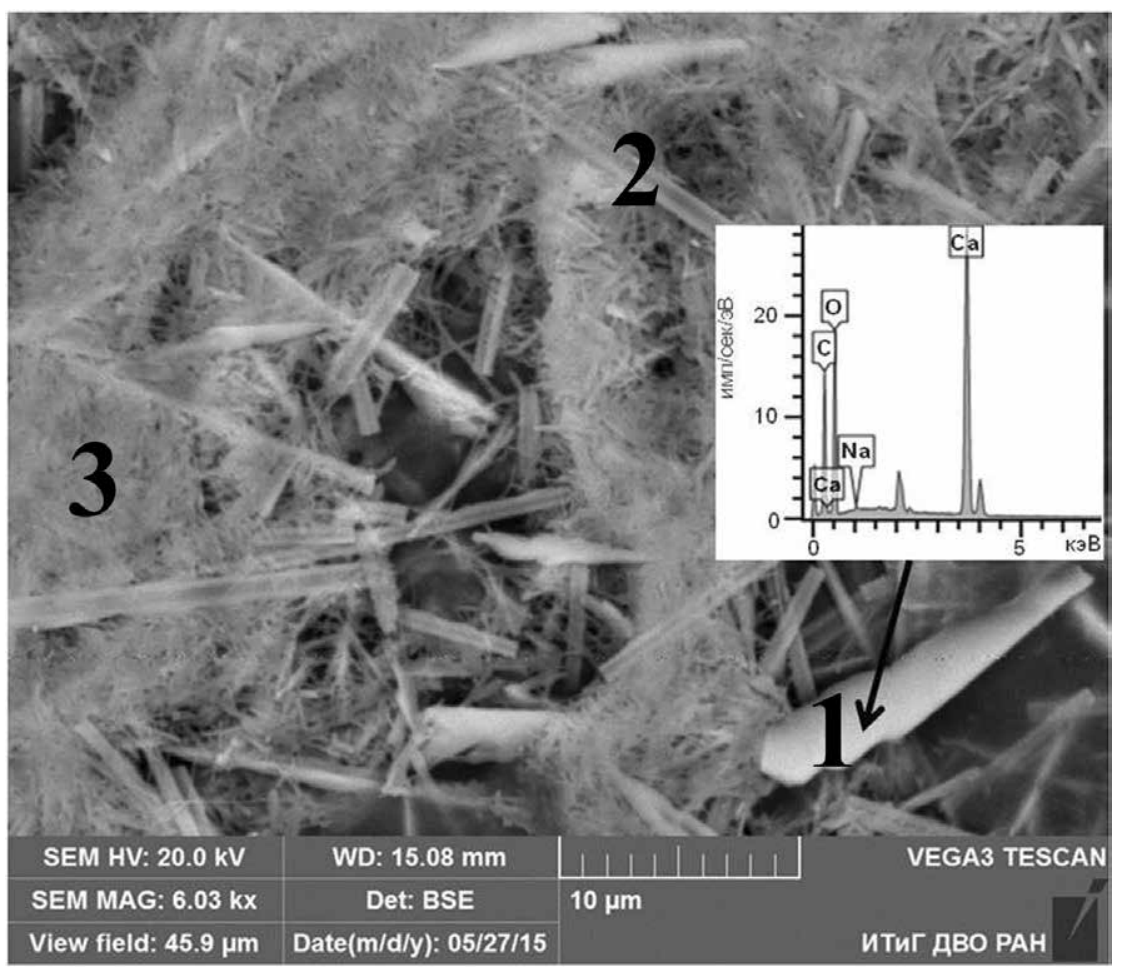

Figure. 6. SEM images of microtructures of moonmilk speleothem in the Proschalnaya Cave: (1) claviform, (2) tubular microstructures, and (3) nanofibres. Magnification: $6000 x$. and Ferris, 2006), and take an active part in induced calcium carbonate precipitation (Achal and Pan, 2014).

Molecular investigations of moonmilk sampled from the Proschalnaya Cave revealed the presence of iron bacteria

of the genera Rhodoferax and Geothrix (Table 3) that are commonly found in iron-containing groundwater. Members of substances (NOS) and differing slightly in the dominant morphotype of the colonies. Moreover, in a thin layer of curdy mass the abundance of different groups was higher than in a thicker layer of moonmilk. During cultivation on SAA containing starch as a carbon source, the abundance of bacteria was low in three samples. Periodically, violet-colored colonies, growing on Bromfield media containing $\mathrm{Fe}(\mathrm{OH})_{3}$, were isolated from moonmilk. Such differences can be associated with different stages of the formation of biofilms from moonmilk and physico-chemical conditions at the sampling sites.

Minimal diversity of colony morphotypes and low abundance were recorded in the sample of dense slimy moonmilk. There is evidence that the structure of the microbial community strongly affects the intensity of $\mathrm{CaCO}_{3}$ deposition and the composition of moonmilk (Cirigliano et al., 2018). High concentrations of calcium carbonate are able to precipitate in the slimy matrix and inhibit the development of bacteria. The physiological adaptation of bacteria to toxic $\mathrm{Ca}^{2+}$ ions occurs by calcification in $\mathrm{Ca}^{2+}$-rich cave environments. Such activity creates the initial crystal nucleation sites that contribute to the formation of secondary $\mathrm{CaCO}_{3}$ deposits within caves (Banks et al., 2010).

On the basis of cultural-morphological characteristics and a proposed scheme for identification of bacteria of the genus Bacillus (Vasiliev, 2013) with use of a series of tests (growth on citrate, arabinose, xylose, mannitol, urea, raffinose; catalase activity, and $\mathrm{H}_{2} \mathrm{~S}$ secretion). Among the twenty strains isolated from moonmilk in the Proschalnaya Cave, two strains were identified as Bacillus. It can be assumed the surface waters that drain the soil and karst rocks can act as the main source determining the composition of moonmilk. Bacillus are capable of producing polymeric slime and act as catalysts for the biogenic mineralization and weathering of rocks (Ercole et al., 2007). Bacillus can act as typical soil chemo-organotrophic bacteria that occur in freshwater, participate in the nitrogen cycle, and can reduce iron (Garcia et al., 2016). These bacteria are the centers of crystal formation, affect the morphology of crystals, the solubility of carbonates (Mitchel 
Table 3. Molecular genetics (qPCR) analysis of moonmilk, sampled from the Proschalnaya cave.

\begin{tabular}{cccc} 
Sample Description & $\begin{array}{c}\text { Total number of eubacterial } \\
\text { DNA gene copies/g }\end{array}$ & $\begin{array}{c}\text { Number of the Rhodoferax } \\
\text { DNA gene copies/g }\end{array}$ & $\begin{array}{c}\text { Number of the Geothrix } \\
\text { DNA gene copies/g }\end{array}$ \\
\hline M1: thin slimy white mass & $1.17 \times 10^{9}$ & $5.64 \times 10^{6}$ & $3.25 \times 10^{5}$ \\
M2: thick curdy ivory-white mass & $1.08 \times 10^{9}$ & $1.44 \times 10^{6}$ & $3.76 \times 10^{5}$ \\
\hline
\end{tabular}

Table 4. Elemental composition of nanostructures included in the composition of moonmilk in the Proschalnaya Cave.

\begin{tabular}{|c|c|c|c|}
\hline \multirow[b]{2}{*}{ Elements } & \multicolumn{3}{|c|}{ Weight Percent } \\
\hline & Tubular Nanostructure & Claviform Nanostructure & Nanofibres \\
\hline C & $19 \pm 1$ & $22 \pm 2$ & $41.5 \pm 1.5$ \\
\hline $\mathrm{O}$ & $59 \pm 1$ & $65 \pm 3$ & $64 \pm 2$ \\
\hline $\mathrm{Ca}$ & $17.5 \pm 2.5$ & $9.5 \pm 3.5$ & $12.5 \pm 2.5$ \\
\hline $\mathrm{Na}$ & $\cdots$ & $0.325 \pm 0.175$ & $0.91 \pm 0.41$ \\
\hline $\mathrm{Fe}$ & $0.22 \pm 0.04$ & $\cdots$ & $\cdots$ \\
\hline $\mathrm{Mn}$ & $0.105 \pm 0.005$ & $\cdots$ & $\cdots$ \\
\hline $\mathrm{Si}$ & $0.87 \pm 0.17$ & $\cdots$ & $0.135 \pm 0.055$ \\
\hline $\mathrm{Al}$ & $0.63 \pm 0.1$ & $\cdots$ & $\cdots$ \\
\hline $\mathrm{S}$ & $0.06 \pm 0.01$ & $\cdots$ & $0.505 \pm 0.245$ \\
\hline
\end{tabular}

the genus Rhodoferax are psychrotolerant facultative anaerobes that often use $\mathrm{Fe}(\mathrm{OH})_{3}$ as an electron acceptor (Finnerant et al., 2003). Geothrix fermentans is found within the Fe (III) reduction zone of subsurface environments. Such iron bacteria have been shown to attach to the surface of mineral particles by the production of adhesive biopolymer (Nevin and Lovley, 2002). We assume that Rhodoferax and Geothrix acting as primary colonizers, initiate the first stage of biofilm formation and create conditions favorable for the growth of other heterotrophic bacteria in moonmilk.

Bacteria capable of oxidizing iron and manganese have been repeatedly found in cave sediments. The presence of Flavobacterium spp. in the Iron Curtain Cave indicates that it might potentially participate in iron oxidation (Ghosh et al., 2017). Flavobacterium spp. was previously reported in abundance in ferromanganese deposits from the caves of the Upper Tennessee River Basin, along with other bacteria indicating that this bacterium contributed to Mn (II) oxidation (Carmichael et al., 2013).

Calcium salts promoting aggregation of bacterial cells and formation of slimy polymers can accelerate the formation of biofilms and their interaction with rocks (Das et al., 2014). In many cases, microorganisms and their extracellular polymeric substances act as effective centers for the formation of new structures that can lead to passive incrustation of biofilms (Flemming, 2016) and affect the structure of the speleothem (Sallstedt et al., 2014). The production of carbonic anhydrase, the enzyme regulating the equilibrium of inorganic carbon forms such as bicarbonate, can play the key role in the mechanism of biomineralization (Smith and Ferry, 2000; Müller et al., 2014).

\section{Microstructure and elemental composition of the moonmilk from the Proschalnaya Cave}

While speleologists, geologists, and microbiologists have different views on moonmilk genesis, modern research techniques have revealed an important role of biogenic factors in development of a number of sinter formations. Scanning electron microscopy (SEM) of moonmilk from the Grotta Nera Cave (Italy) revealed fibrous formations with calcites identified by X-ray refractometry (Cacchio et al., 2014). An array of elements were detected in the moonmilk, including $\mathrm{Ca}, \mathrm{Mg}, \mathrm{Al}, \mathrm{P}, \mathrm{Si}, \mathrm{S}, \mathrm{Mn}, \mathrm{K}$, and $\mathrm{Fe}$. The proportion of $\mathrm{CaO}$ was as high as $60.87 \%$ in some samples, while the portion of oxides such as $\mathrm{MgO}$ and $\mathrm{Al}_{2} \mathrm{O}_{3}$ never exceeded $1 \%$.

SEM imaging of moonmilk from the Proshchalnaya Cave showed the presence of morphologically distinct microstructures with different elemental composition. Tubular structures in the composition of moonmilk (Fig. 5) distinguished themselves by a rich chemical content. Except for the basic elements indicative of their carbonate genesis $(\mathrm{C}, \mathrm{O}$, and $\mathrm{Ca}$ ), in tubular structures $\mathrm{Al}, \mathrm{Si}$, and $\mathrm{Fe}$ were also present. In one of the loci, impurities of magnesium and sulfur were observed. Al and $\mathrm{Si}$ oxides are often found as impurities in dolomite $\left(\mathrm{CaMg}\left(\mathrm{CO}_{3}\right)_{2}\right)$, which is represented as inclusions in calcite and as part of fine-grained sediments, including in moonmilk (Hill and Forti, 2007). Similar tubular structures called nanofibres were found in caves and relate to secondary calcites (Bindschedler et al., 2014).

Calcium content in different samples of moonmilk from Snezhnaya Cave (Russia, Western Caucasus) indicated differences in nanostructures (Kondratyeva et al., 2016). The highest calcium content (up to $61.54 \%$ by weight) was observed in the cubic crystal microstructures. In this locus, the contents of carbon and magnesium oxides were $33.79 \%$ 
and $3.26 \%$ by weight, respectively. The highest level of carbon oxides (58.62 \% to $82.73 \%$ by weight) characterized the biofilm microstructures. These microstructures also had elevated levels of magnesium oxides (up to $16 \%$ by weight). Detailed scanning of the images of moonmilk from Snezhnaya Cave moonmilk revealed specific microstructures resembling stacks of thin lamellars. Elemental composition of these plates was characterized by relatively low calcium content ( $0.1-0.14 \%$ by weight) and considerably high magnesium content (14.65-22.6 \% by weight).

In a Belgian Cave (Collembola Cave), abundant, randomly-oriented, single-crystal rods, and polycrystalline calcite fibers were present in the structure of moonmilk (Maciejewska et al., 2017). The tubular microstructures in moonmilk from the Proschalnaya Cave had high similarity with these microstructures. Also SEM images of the microstructures in moonmilk from the Proschalnaya Cave were similar to calcitic nanofibres, needle fibre calcite, tubular- and filament-like structures in other scientific literature (Shankar and Achyuthan, 2007; Maciejewska et al., 2015). However, the tubular nanostructures found by us are not similar to the reticulated filaments described earlier (Melim et al., 2008).

Various mechanisms for the formation of nanostructures are proposed: physicochemical processes, such as the deposition of salts on the cell surface or the deposition of calcite crystals on organic matrices; and calcination of fungal mycelium or actinobacteria (Bindschedler et al., 2014; Maciejewska et al., 2015). Proteobacteria, Acidobacteria, and Actinobacteria were the most common phyla in strong association with the needle calcite in moonmilk (Cirigliano et al., 2018).

Needle calcite is a common secondary speleothem (Cailleau et al., 2009). The presence of calcitic nanofibers and needle calcite in secondary $\mathrm{CaCO}_{3}$ sediments can be used to characterize the paleoclimate and assess the ecological situation (Shankar and Achyuthan, 2007). Their ratio can indicate the alternation of arid and semi-arid climatic conditions, although both forms of calcite can also occur in a humid climate (Bindschedler et al., 2012).

For the first time in the mass of moonmilk in the Proschalnaya Cave we discovered claviform nanostructures (Fig. 6). In comparison with tubular structures, they have limited elemental composition (Table 4). The dominant components in these structures are carbon, oxygen, and calcium, but the calcium content in claviform nanostructure is lower than in tubular structures and nanofibers.

In some crystals of ancient calcites, needle structures composed of aragonite $\left(\mathrm{CaCO}_{3}\right)$ are found. It is assumed that, depending on the environmental conditions, sequential precipitation of calcite-aragonite-calcite can occur. The formation of aragonite in speleothems is associated with a high $\mathrm{Mg} / \mathrm{Ca}$ ratio in the drip water, as $\mathrm{Mg}$ is an inhibitor of calcite growth (Wassenburg et al., 2012). In the nanotubes and claviform microstructures we observed that Mg was extremely rare. We assumed that during the formation of the moonmilk mass against the background of a decrease in the amount of rainfall, precipitation of calcites without magnesium occurred, in spite of its presence in groundwater.

\section{Conclusions}

The nature of the interaction of groundwater and surface water varies greater under the influence of the biochemical activity of microorganisms. Due to the movement of waters and the biochemical activity of microorganisms, the most intensive dissolution of the bedrock occurs in the spring, resulting in an increase in the calcium content where fracture and drip water interact with rock. Based on our studies, we assume that the formation of moonmilk in Proschalnaya Cave largely depends on the rate of entry of organic substances and the ratio of elements accumulating in bacterial polymers. Consequently, the movement of surface water and groundwater in the area of Proschalnaya Cave drive the biogeochemical processes important for the formation of moonmilk, and the origin of the water can dictate the mineral composition of the speleothems.

Climatic conditions are an important factor affecting the speed and stages of the formation of the biomass of moonmilk. Microorganisms are producers of polymeric compounds; they act as first settlers in the initial stages of the formation of the biofilm from moonmilk, and then accumulate other elements, forming biominerals. The biospheric approach to the moonmilk speleothem study is based on interdisciplinary research that relies on macro processes (geological and geochemical) and micro processes occurring at the scale of microbial cells and biofilms. Calcite transformation and geomorphology of karst caves are changed due to the specific formation of biofilms. Moonmilk provides clear evidence of the role of biofilms in transformation of rocks in underground ecosystems.

\section{Acknowledgments}

The authors are grateful to V.O. Shadrin, the leader of the expedition to the Proschalnaya Cave in 2015-2017, to N.S. Konovalova for scanning electron microscopy, to O. Hershey (University of Akron, Akron Ohio, USA) for help with English translation, and to colleagues for help in sampling.

\section{References}

Achal, V. and Pan X., 2014, Influence of calcium sources on microbially induced calcium carbonate precipitation by Bacillus sp. CR2: Journal of Applied Biochemistry and Biotechnology, v. 173, no. 1, p. 307-314. https://doi.org/10.1007/s12010-014-0842-1 
Banks, E.D., Taylor, N.M., Gulley, J., Lubbers, B.R., Giarrizzo, J.G., Bullen, H.A., Hoehler, T.M., and Barton, H.A., 2010, Bacterial calcium carbonate precipitation in cave environments: a function of calcium homeostasis: Geomicrobiology Journal, v. 27, p. 444-454. https://doi. org/10.1080/01490450903485136

Barton, H.A., Taylor, M.R., and Pace, N.R., 2004, Molecular phylogenetic analysis of a bacterial community in an oligotrophic cave environment: Geomicrobiology Journal, v. 21, p. 11-20. https://doi.org/10.1080/01490450490253428

Barton, H.A. and Northup, D.E., 2007, Geomicrobiology in cave environments: past, current and future perspectives: Journal of Cave and Karst Studies, v. 69, p. 163-178.

Bersenyov, Yu.I., 1989, Karst of the Far East: Moscow, Nauka, 172 p. (in Russian)

Bindschedler, S., Cailleau, G., Braissant, O., Millière, L., Job, D., and Verrecchia, E.P., 2014, Unravelling the enigmatic origin of calcitic nanofibres in soils and caves: purely physicochemical or biogenic processes?: Biogeosciences, v. 11, p. 2809-2825. https://doi.org/10.5194/bg-112809-2014

Bindschedler, S., Millière, L., Cailleau, G., Job, D., and Verrecchia, E.P., 2012, An ultrastructural approach to analogies between fungal structures and needle fibre calcite: Geomicrobiology Journal, v. 29, p. 301-313. https://doi.org/10.1080/01490451.2011.558565

Borsato, A., Frisia, S., Jones, B., and Van der Borg, K., 2000, Calcite Moonmilk: crystal morphology and environment of formation in caves in the Italian Alps: International Journal of Sediment Research, v. 70, p. 1179-1190. https://doi.org/10.1306/032300701171

Braun, B., Schröder, J., Knecht, H., and Szewzyk, U., 2016, Unraveling the microbial community of a cold groundwater catchment system: Water Research, v. 107, p. 113-126. https://doi.org/10.1016/j.watres.2016.10.040

Cacchio, P., Ferrini, G., Ercole, C., Del Gallo, M., and Lepidi, A., 2014, Biogenicity and characterization of moonmilk in the Grotta Nera (Majella National Park, Abruzzi, central Italy): Journal of Cave and Karst Studies, v. 76, p. 88-103. https://doi.org/10.4311/2012mb0275

Cailleau, G., Verrecchia, E.P., Braissant, O., and Emmanuel, L., 2009, The biogenic origin of needle fibre calcite: Sedimentology, v. 56, p. 1858-1875. https://doi.org/10.1111/j.1365-3091.2009.01060.x

Canaveras, J.C., Cuezva, S., Sanchez-Moral, S., Lario, J., Laiz, L., Gonzalez, J.M., and Saiz-Jimenez, C., 2006, On the origin of fiber calcite crystals in moonmilk deposits: Naturwissenschaften, v. 93, p. 27-32. https://doi.org/10.1007/s00114-005-0052-3

Carmichael, M.J., Carmichael, S.K., Santelli, C.M., Strom, A., and Brauer, S.L., 2013, Mn(II)-oxidizing bacteria are abundant and environmentally relevant members of ferromanganese deposits in caves of the upper Tennessee river basin: Geomicrobiology Journal, v. 30, p. 779-800. https://doi.org/10.1080/01490451.2013.769651

Chelius, M.K., Beresford, G., Horton, H., Quirk, M., Selby, G., Simpson, R.T., Horrocks, R., and Moore, J.C., 2009, Impacts of alterations of organic inputs on the bacterial community within the sediments of Wind Cave, South Dakota, USA: International Journal of Speleology, v. 38, p. 1-10. https://doi.org/10.5038/1827-806x.38.1.1

Chen, Y., Wu, L., Boden, R., Hillebrand, A., Kumaresan, D., and Moussard, H., 2009, Life without light: microbial diversity and evidence of sulfurand ammoniumbased chemolithotrophy in Movile cave: Journal of the International Society for Microbial Ecology, v.3, no. 9, p. 1093-1104. https://doi.org/10.1038/ismej.2009.57

Cirigliano, A., Tomassetti, M.C., Di Pietro, M., Mura, F., Maneschi, M.L., Gentili, M.D., Cardazzo, B., Arrighi, C., Mazzoni, C., Negri, R., and Rinaldi, T., 2018, Calcite moonmilk of microbial origin in the Etruscan Tomba degli Scudi in Tarquinia: Italy Scientific Reports, v. 8, no. 1, p. 1-10. https://doi.org/10.1038/s41598-018-34134-y

Das, T., Sehar, S., Koop, L., Wong, Y.K., and Ahmed, S., 2014, Influence of calcium in extracellular DNA mediated bacterial aggregation and biofilm formation: Plos One, v. 9, no. 3, p. 1-11. https://doi.org/10.1371/journal.pone.0091935

De Mandal, S., Chatterjee, R., and Kumar, N.S., 2017, Dominant bacterial phyla in caves and their predicted functional roles in C and N cycle: BMC Microbiology, v. 17, no. 1, p. 1-9. https://doi.org/10.1186/s12866-017-1002-x

Egorov, N.S., 1995, Microbiology Practice Guidance: Moscow, MGU, 224 p. (in Russian)

Ercole, C., Cacchio, P., Botta, A.L., Centi, V., and Lepidi, A., 2007, Bacterially induced mineralization of calcium carbonate: the role of exopolysaccharides and capsular polysaccharides: Microscopy and Microanalysis, v. 13, p. 42-50. https://doi.org/10.1017/s1431927607070122

Federation Regulation F 14.1: 2: 4.143-98, 2011 ed., Quantitative chemical analysis of water. Method for measuring the mass concentration of aluminum, barium, boron, iron, potassium, calcium, cobalt, magnesium, manganese, copper, sodium, nickel, strontium, titanium, chromium and zinc in drinking, natural and waste waters by ICP spectrometry method, FR.1.31.2013.13911; https://www.russiangost.com/p-275435fr131201313911.aspx

Ferris, F.G., 2005, Biogeochemical properties of bacteriogenic iron oxides: Geomicrobiology Journal, v. 22, no. 3-4, p. 79-85. https://doi. org/10.1080/01490450590945861

Finnerant, K.T., Johnsen, C.V., and Lovley, D.R., 2003, Rhodoferax ferrireducens sp. nov., a psychrotolerant, facultatively anaerobic bacterium that oxidizes acetate with the reduction of Fe (III): International Journal of Systematic and Evolutionary Microbiology, v. 53, p. 669-673. https://doi.org/10.1099/ijs.0.02298-0

Flemming, H.C., 2016, EPS—then and now: Microorganisms, v. 4, no. 4, 41 p. https://doi.org/10.3390/microorganisms4040041

Fornós, J.J., Ginés, J., Gràcia, F., Merino, A., Gómez-Pujol, L., and Bover, P., 2014, Cave deposits and sedimentary processes in Cova des Pas de Vallgornera (Mallorca, Western Mediterranean): International Journal of Speleology, v. 43, no. 2, p. 159-174. http://dx.doi. org/10.5038/1827-806X.43.2.5

Garcia, G.M., Márquez, G.M.A., and Moreno, H.C.X., 2016, Characterization of bacterial diversity associated with calcareous deposits and drip-waters, and isolation of calcifying bacteria from two Colombian mines: Microbiological Research, v. 182, p. 21-30. https://doi. org/10.1016/j.micres.2015.09.006

Gerhardt, F., 1983, General Bacteriology Methods: Moscow, Mir, 536 p. (in Russian)

Ghosh, S., Paine, E., Wall, R., Kam, G., Lauriente, T., Sangarmangkang, P.C., Derrick Horne, D., and Cheeptham, N., 2017, In situ cultured bacterial diversity from iron Curtain Cave, Chilliwack, British Columbia, Canada: Diversity, v. 9 , no. 3, p. 1-15. https://doi.org/10.3390/d9030036

Hill, C.A. and Forti, P., 2007, Cave mineralogy and the NSS: past, present, future: Journal of Cave and Karst Studies, v. 69, p. 35-45.

Kondratyeva, L.M., Polevskaya, O.S., Litvinenko, Z.N., Golubeva, E.M., and Konovalova, N.S., 2016, Role of the microbial community in formation of speleothem (moonmilk) in the Snezhnaya karst cave (Abkhazia): Microbiology (Moscow), v. 85, no. 5, p. 629-637. https://doi. org/10.1134/s002626171605009x

Kubista, M., Andrade, J.M., Bengtsson, M., Forootan, A., Jonake, J., Lind, K., Sindelka, R., Sjoback, R., Sjogreen, B., Strombom, L., Stahlberg, A., and Zoric, N., 2006, The real-time polymerase chain reaction: Molecular Aspects of Medicine, v. 27, p. 95-125. https://doi.org/10.1016/j. mam.2005.12.007

Kuhn, K.M., DuBois, J.L., and Maurice, P.A., 2014, Aerobic microbial Fe acquisition from ferrihydrite nanoparticles: effects of crystalline order, siderophores, and alginate: Environmental Science and Technology, v. 48, no. 15, p. 8664-8670. https://doi.org/10.1021/es501308b 
Kuznetsov, S.I. and Dubinina, G.A., 1989, Methods for the Study of Aquatic Microorganisms: Moscow, Nauka, 288p. (in Russian)

Lefevre, E., Bossa, N., Wiesner, M.R, and Gunsch, C.K., 2016, A review of the environmental implications of in situ remediation by nanoscale zero valent iron (nZVI): behavior, transport and impacts on microbial communities: Science of the Total Environment, v. 565, p. 889-901. https://doi.org/10.1016/j.scitotenv.2016.02.003

Maciejewska, M., Adam, D., Naômé, A., Martinet, L., Tenconi, E., Całusińska, M., Delfosse, P.,

Müller, W.E., Schlossmacher, U., Schröder, H.C., Lieberwirth, I., Glasser, G., Korzhev, M., Neufurth, M., and Wang, X., 2017, Enzyme-accelerated and structure-guided crystallization of calcium carbonate: role of the carbonic anhydrase in the homologous system: Acta Biomaterialia, $v$. 10, no.1, p. 450-462. https://doi.org/10.3389/fmicb.2017.01181

Maciejewska, M., Pessi, I.S., Arguelles-Arias, A., Noirfalise, P., Luis, G., Ongena, M., Barton, H., Carnol, M., and Rigali, S., 2015, Streptomyces Iunaelactis sp. nov., a novel ferroverdin A-producing Streptomyces species isolated from a moonmilk speleothem: Antonie van Leeuwenhoek, v. 107, no. 2, p. 519-531. https://doi.org/10.1007/s10482-014-0348-4

Margesin, R., 2009, Effect of temperature on growth parameters of psychrophilic bacteria and yeasts: Extremophiles, v. 13, no. 2, p. $257-262$. https://doi.10.1007/s00792-008-0213-3

Melim, L. A., Northup, D. E., Spilde, M. N., Jones, B., Boston, P. J., and Bixby, R. J, 2008, Reticulated filaments in cave pool speleothems: microbe or mineral?: Journal of Cave and Karst Studies, v. 70, p. 135-141. https://doi.org/10.7939/R3J38KZ7V

Mitchell, A.C. and Ferris F.G., 2006, The influence of Bacillus pasteuriion the nucleation and growth of calcium carbonate: Geomicrobiology Journal, v. 23, p. 213-226. https://doi.org/10.1080/01490450600724233

Müller, W.E., Schlossmacher, U., Schröder, H.C., Lieberwirth, I., Glasser, G., Korzhev, M., Neufurth, M., and Wang, X., 2014, Enzyme-accelerated and structure-guided crystallization of calcium carbonate: role of the carbonic anhydrase in the homologous system: Acta Biomaterialia, $v$. 10, no. 1, p. 450-462. https://doi.org/10.1016/j.actbio.2013.08.025

Namsaraev, B.B., Barkhutova, D.D., Khakhinov, V.V., 2006, Field workshop on aquatic microbiology and hydrochemistry: Methodical manual/ Ed M. B. Vainshtein: Moscow-Ulan-Ude, Publishing House of the Buryat State University, $68 \mathrm{p}$.

Nevin, K.P. and Lovley, D.R., 2002, Mechanisms for accessing insoluble Fe (III) oxide during dissimilatory Fe (III) reduction by Geothrix fermentans: Applied Environmental Microbiology, v. 68, no. 5, p. 2294-2299. https://doi.org/10.1128/aem.68.5.2294-2299.2002

Perry, T.D., Duckworth, O.W., McNamara, C.J., Martin, S.T., and Mitchell, R., 2004, Effects of the biologically produced polymer alginic acid on macroscopic and microscopic calcite dissolution rates: Environmental Science and Technology, v. 38, p. 3040-3046. https://doi.org/10.1021/ es035299a

Porca, E., Jurado, V., Zgur-Bertok, D., Saiz-Jimenez, C., and Pasic, L., 2012, Comparative analysis of yellow microbial communities growing on the walls of geographically distinct caves indicates a common core of microorganisms involved in their formation: FEMS Microbiology Ecology, v. 81, p. 255-266. https://doi.org/10.1111/j.1574-6941.2012.01383.x

Portillo, M.C. and Gonzales, J.M., 2011, Moonmilk deposits originate from specific bacterial communities in Altamira Cave (Spain): Microbial Ecology, v. 61, p. 182-189. https://doi.org/10.1007/s00248-010-9731-5

Reitschuler, C., Spötl, C., Hofmann, K., Wagner, A.O., and IIImer, P., 2016, Archaeal distribution in moonmilk deposits from Alpine caves and their ecophysiological potential: Microbial Ecology, v. 71, no. 3, p. 686-699. https://doi.org/10.1007/s00248-015-0727-z

Rodrigues, D.F. and Tiedje, J.M., 2008, Coping with our cold planet: Applied Environmental Microbiology, v. 74, p. 1677-1686. https://doi.10.1128/ AEM.02000-07

Sallstedt, T., Ivarsson, M., Lundberg, J., Sjöberg, R., and Vidal Romaní, J.R., 2014, Speleothem and biofilm formation in a granite/dolerite cave, Northern Sweden: International Journal of Speleology, v. 43, no. 3, p. 305-313. https://doi.org/10.5038/1827-806x.43.3.7

Shankar, N. and Achyuthan, H., 2007, Genesis of calcic and petrocalcic horizons from Coimbatore, Tamil Nadu: micromorphology and geochemical studies: Quaternary International, v. 175, p. 140-154. https://doi.org/10.1016/j.quaint.2007.05.017

Shesterkin V.P., 1983, Chemical Content of Groundwater and Ice From Proschalnaya Cave. Genesis of groundwater: Irkutsk, Institute of the Earth's Crust, 140 p. (in Russian)

Smith, K.S. and Ferry, J.G., 2000, Prokaryotic carbonic anhydrases: FEMS Microbiology Reviews, v. 24, p. 335-366. https://doi.org/10.1016/ s0168-6445(00)00030-9

Struvay, C. and Feller, G., 2012, Optimization to low temperature activity in psychrophilic enzymes: International Journal of Molecular Sciences, v.13, no. 9, p. 11643-11665. https://doi.org/10.3390/ijms130911643

Vasiliev, D.A., Kaldyrkaev, A.I., Feoktistova, N.A., and Aleshkin, A.V., 2013, Identification of Bacillus cereus Bacteria Based on Their Phenotypic Characteristics: Uliyanovsk, Nauchnoe izdanie, 98 p. (in Russian)

Velikonja, B.H., Tkavc, R., and Paši'c, L., 2014, Diversity of cultivable bacteria involved in the formation of macroscopic microbial colonies (cave silver) on the walls of a cave in Slovenia: International Journal of Speleology, v. 43, p. 45-56. https://doi.org/10.5038/1827-806x.43.1.5

Wassenburg, J.A., Immenhauser, A., Richter, D.K., Jochum, K.P., Fietzke, J., Deininger, M., Goos, M., Scholz, D., and Sabaoui, A., 2012, Climate and cave control on Pleistocene/Holocene calcite-to-aragonite transitions in speleothems from Morocco: elemental and isotopic evidence: Geochimica et Cosmochimica Acta, v. 92, p. 23-47. https://doi.org/10.1016/j.gca.2012.06.002

Wu, Y., Tan, L., Liu, W., Wang, B., Wang, J., Cai, Y., and Lin, X., 2015, Profiling bacterial diversity in a limestone cave of the western loess plateau of China: Frontiers in Microbiology, v. 6, no. 244, p. 1-10. https://doi.org/10.3389/fmicb.2015.00244 


\title{
ENZYME PROFILES AND ANTIMICROBIAL ACTIVITIES OF BACTERIA ISOLATED FROM THE KADIINI CAVE, ALANYA, TURKEY
}

\author{
Nihal Doğruöz-Güngör ${ }^{1, C}$, Begüm Çandıroğlu², and Gülşen Altuğ ${ }^{3}$
}

\begin{abstract}
Cave ecosystems are exposed to specific environmental conditions and offer unique opportunities for bacteriological studies. In this study, the Kadıini Cave located in the southeastern district of Antalya, Turkey, was investigated to document the levels of heterotrophic bacteria, bacterial metabolic avtivity, and cultivable bacterial diversity to determine bacterial enzyme profiles and antimicrobial activities. Aerobic heterotrophic bacteria were quantified using spread plates. Bacterial metabolic activity was investigated using DAPI staining, and the metabolical responses of the isolates against substrates were tested using VITEK 2 Compact 30 automated micro identification system. The phylogenic diversity of fourty-five bacterial isolates was examined by $16 \mathrm{~S}$ rRNA gene sequencing analyses. Bacterial communities were dominated by members of Firmicutes (86 \%), Proteobacteria (12\%) and Actinobacteria (2\%). The most abundant genera were Bacillus, Staphylococcus and Pseudomonas. The majority of the cave isolates displayed positive proteolytic enzyme activities. Frequency of the antibacterial activity of the isolates was $15.5 \%$ against standard strains of Bacillus subtilis, Staphylococcus epidermidis, S.aureus, and methicillin-resistant S.aureus. The findings obtained from this study contributed data on bacteriological composition, frequency of antibacterial activity, and enzymatic abilities regarding possible biotechnological uses of the bacteria isolated from cave ecosytems.
\end{abstract}

\section{Introduction}

Caves are among the extreme environments in the world due to the low and generally stable temperature, minimum light, low nutrients, and high humidity (Palmer 1991; Tomczyk-Żak and Zielenkiewicz 2015). There are many cave types around the world and many different classifications have been used for these geological forms (Northup and Lavoie 2001; Engel 2011). Karstic caves are the most common, formed through geomorphological and microbiological processes (Engel 2010; Tisato et al., 2015; Bontognali et al., 2016). One of the critical subjects in cave research is the adaptation of cave microorganisms to extreme conditions. Previous studies have shown many different microorganis$\mathrm{ms}$ in caves and identified them from water bodies, on rocky surfaces, in guanos, and on sediments (Herzog Velikonja et al., 2014; Tomczyk-Żak and Zielenkiewicz 2015). Organic materials introduced by people, dripping water, floods, and animals, especially bats, create an environment that allows heterotrophic bacteria to grow in caves (Borda et al., 2014). Microorganisms may enter caves through different processes. Water, wind or air conditions may facilitate their transportation, or sometimes animals can carry microorganisms into caves (Romero 2009). Other transportation paths of microorganisms are created by humans, resulting in changes to native microbial communities. Difficult environmental conditions and low nutrients in cave environments create competition among microorganisms, which can produce antibiotics against each other in these environments (Bhullar et al., 2012). This natural process offers unique opportunities for biotechnological applications and possible uses of new bioactive substances, including new antibiotics.

Appliations of enzymes in techology is a rapidly-developing field, and is increasingly dependent on microbial enzymes. Microbial enzymes are more stable and are produced at a faster rate in greater amounts, making them the preferred source of enzymes. These enzymes take an important role in the diagnosis, treatment, industrial applications, biochemical tests and monitoring of various diseases. Moreover, diverse peptidases with particular biochemical properties have been identified from studies of microbial diversity of bacteria and fungi. This has provided a broad range of peptidase applications, particularly in the field of microbial biochemistry. For this reason, it is important to identify bacteriological community structure and metabolic characteristics in caves ecosytems.

The study has three main goals:

1. to investigate the levels of culturable aerobic heterotrophic bacteria (HPC), cultivable bacterial composition, and the frequency of metabolically-active bacteria in a cave ecosystem;

2. to detect the frequency of antimicrobial activities of the cave isolates against selected bacteria;

3. to evaluate biotechnological potential of the cave isolates regarding metabolic definition, biochemical reactions, and enzyme profiles.

${ }^{1}$ Istanbul University, Faculty of Science, Department of Biology, 34134 Vezneciler, Istanbul, Turkey

${ }^{2}$ Istanbul University, Institute of Sciences, 34134 Vezneciler, Istanbul, Turkey

${ }^{3}$ Istanbul University, Faculty of Aquatic Science, Department of Marine Biology, 34470 Laleli, Istanbul, Turkey

cCorresponding author: ndogruoz@istanbul.edu.tr 


\section{Materials and Methods}

\section{Cave background and sampling site}

Kadıini Cave, which is closed to tourist activities, is located in Obaköy, a village $3.8 \mathrm{~km}$ away from Alanya, a southeastern district of Antalya, Turkey (Fig. 1). Kadiini Cave is a horizontal cave with a length of $2027 \mathrm{~m}$ and a depth of $45 \mathrm{~m}$ (Turkey Cave Database). The first research in the Kadini Cave was conducted in 1957. During the research, human skeletons and archaeological finds such as cups, hearths, whorls and stone tools were found. The human skeletons are from 6000 years ago and showed that people used the cave as a living/shelter space. The entrance hall of the Kadini Cave is a gallery that is rich in terms of stalactites and stalagmites. It was a place of settlement during the Upper Paleolithic and the Early Bronze Age (Yılmazusta and Yakup Ipekoğlu 2019). Members of the Akdeniz University Cave Research Club (AKÜMAK) began investigating the Kadini Cave in 2008 and delving into the unexplored cave sections. In 2014, the Anatolian Speleology Association (ASPEG) started to support these studies. During sampling it was observed that the source of organic substances is guano and the water seeping through the walls. 650 bats of which 400 Rousettus aegyptiacus, 200 Rhinolophus blasii and 50 Miniopterus schreibersii were identified in the project entitled "Identification and Protection of Important Bat Caves in Turkey" that was carried out in 2012 in the Kadiini Cave (Coraman et al., 2012). There is also an underground stream at the end of the cave.

\section{Sample collection}

Water and soil samples were collected under aseptic conditions in the two different sites from the dark zone of the Kadini Cave (Fig. 1). The samples were maintained at $4{ }^{\circ} \mathrm{C}$ and transported within 24 hours to the laboratory.

\section{Variable environmental parameters of the sampling area}

The water samples collected from the cave were measured in situ in terms of temperature, $\mathrm{pH}$, dissolved oxygen, conductivity, total dissolved solids (TDS) and salinity using a portable multiparameter tool (a Hach Lange HQ40D multimeter). Air temperature and humidity at the two investigation sites were also measured by a portable temperature/ humidity meter. The Mann-Whitney $U$ test was used to determine statistically significant changes between measured environmental parameters of the two sample regions. All analyzes were performed using SPSS for Windows Version IBM 21 and $P<0.05$ was considered statistically significant.

\section{Bacteriological analyses}

For the analyses of bacteria, $200 \mathrm{~mL}$ water samples were concentrated with a $0.22 \mu \mathrm{m}$ pore size polyamide filter and then the filters were re-suspended in $20 \mathrm{~mL}$ sterile tap water using a homogenizator (IUL Instruments) for 2 min. For soil samples, one gram was weighed and homogenized in flasks containing $9 \mathrm{~mL}$ of sterile saline water. Serial dilutions of water and soil $\left(10^{-1}\right.$ to $\left.10^{-7}\right)$ were then prepared with sterile saline water and were used as an inoculum for the isolation and



Figure 1. Map of the Kadini cave, Alanya, Antalya-Turkey. enumeration of HPC counts. To estimate the number of aerobic heterotrophic bacteria, triplicate $100 \mu \mathrm{L}$ volumes of each dilution $\quad\left(10^{-1}\right.$ to $10^{-7}$ ) were spread onto R2A (OXOID) agar plates. These plates were aerobically incubated at $28^{\circ} \mathrm{C}$ for 7 days. After the incubation, for each water and soil samples, the dilution that 
was counted contained between 30 and 300 colonies and expressed as the log of the total number of colony forming units (CFU) (Reasoner and Geldrich 1985).

Different colonies that grew on R2A plates were selected and stored at $-86{ }^{\circ} \mathrm{C}$ for subsequent testing of the isolates. To determine the direct viable counts of actively respiring bacteria and the total number of the bacteria cells, the redox dye, 5-cyano-2,3-ditolyl tetrazolium chloride (CTC) and the DNA-binding fluorochrome, 4',6-diamidino-2-phenylindole (DAPI) were used (Schwartz et al., 2003). CTC was used together with DAPI to distinguish between the metabolically active cells and the dead cells. The waters and soil suspensions $(900 \mu \mathrm{l})$ were incubated with the aliquots of a $50 \mathrm{mM}$ CTC redox dye solution to a final concentration of $5 \mathrm{mM}$ in the dark at $28^{\circ} \mathrm{C}$ for $4 \mathrm{~h}$. After the CTC incubation, $1.0 \mu \mathrm{g} / \mathrm{mL}$ DAPI solution was added to the samples and incubated for $1 \mathrm{~h}$ in the dark at $28^{\circ} \mathrm{C}$. After incubation, the samples were filtered by a vacuum filtration onto black $0.2 \mu \mathrm{m}$ pore size polycarbonate filters. The membrane was placed on a glass slide and examined under the oil immersion in a Nikon 80i microscope which was equipped with appropriate filters for CTC and DAPI. The number of bacteria was calculated from the counts of 20 randomly selected microscopic fields (at $1000 \times$ ). For all the bacterial counting, an eyepiece with a calibrated graticule was used. The estimation of the number of cells in each sample was calculated using (Dogruoz Güngör and Sanli Yurudu 2015)

$$
N=\frac{S n}{C V} D,
$$

where $N$ is the number of microorganisms per milliliter, $S$ is the real area of filtration, $n$ is the average number of microorganisms per field of vision, $C$ is the real area of microscopic range, $V$ is the volume of filtered sample, and $D$ is the sample dilution.

\section{$16 S$ rDNA amplification}

For the identification of isolates, their genomic DNA was isolated by using a bacterial DNA isolation kit (GeneAll Biotechnology, Seoul, Korea). The isolated DNA was amplified by 27F (5'-AGAGTTTGATCCTGGCTCAG-3') and 1492R (5'-GGTTACCTTGTTACGACTT-3') universal primers. The reaction was performed in a volume of $50 \mu \mathrm{L}$, comprising 20 nM each primer, $10 \mathrm{ng}$ of cDNA, $2.5 \mathrm{U}$ of Taq DNA polymerase (Bioline, UK), in a single block thermal cycler (Bio-rad, California, USA). The cycle conditions were at $95^{\circ} \mathrm{C}$ for $1 \mathrm{~min}$ initial DNA denaturation, followed by 35 cycles consisting of $15 \mathrm{~s}$ denaturation at $95^{\circ} \mathrm{C}, 15 \mathrm{~s}$ annealing at $55^{\circ} \mathrm{C}$, and $10 \mathrm{~s}$ extension at $72^{\circ} \mathrm{C}$. The PCR products were sequenced by the Sanger sorting method. Sequences were read by the ABI 3130 Sequencer (Applied Biosystems). Sequences and the top BLAST hit in NCBI were edited. The16S rDNA sequences were deposited in GenBank (NCBI) under the accession numbers MK491005-MK491049.

\section{Biochemical characterization and enzyme profiles of the isolates}

To determine biochemical characterization and enzyme profiles of bacterial isolates, a Gram stain, a catalase test, and an oxidase test were conducted. Then they were identified by using GN (Gram-negative fermenting and non-fermenting bacilli), GP (Gram-positive cocci and non-spore-forming bacilli) and BCL (Gram-positive spore-forming bacilli) cards in the automated micro identification system, specialized for environmental samples with industrial software, VITEK 2 Compact 30 (bioMerieux, France). The identification cards are predicated upon the established biochemical methods and recently developed substrates. The calculations are conducted on raw data and compared to thresholds to designate reactions for each test (Pincus 2005).

\section{Evaluation of antimicrobial activity}

By using inhibition zone technique, antimicrobial activity of the isolated bacteria were tested against bacterial strains, including pahogens [S.epidermidis (ATCC 12228), B.subtilis (ATCC 6633), S.aureus (ATCC 6538), P.aeruginosa (ATCC 9027), E.coli (ATCC 8739), methicillin resistant Staphylococcus aureus (MRSA) (ATCC 33591) and vancomycin-resistant enterococci (VRE) (ATCC 51299)]. Each cave isolate was suspended in saline solution to obtain a concentration of $3 \times 10^{8} \mathrm{CFU} / \mathrm{mL}$, then $0.1 \mathrm{~mL}$ of the suspensions were spread onto Muller Hinton Agar plates with a Drigalski spatula. Suspensions of the standard bacteria were prepared in saline solution with a final concentration of $1.5 \times 10^{8} \mathrm{CFU} / \mathrm{mL}$ then spread $(0.1 \mathrm{~mL})$ on the surface of Muller Hinton Agar plates using a Drigalski spatula. A small part $(6 \times 6 \mathrm{~mm})$ of each cave isolate growth was cut and placed on the surface of the inoculated standard strains plates with a nichrome wire loop.

A small part of sterile Muller Hinton agar $(6 \times 6 \mathrm{~mm})$ was placed on to surface of the inoculated standard strains plate as negative control. Disc of standard antibacterial agents erythromycin (15 $\mu \mathrm{g})$ (OXOID discs, UK), vancomycin (30 $\mu \mathrm{g})$ (OXOID discs, UK) , neomycin $(10 \mu \mathrm{g})$ (OXOID discs, UK), gentamicin (10 $\mu \mathrm{g})$ (OXOID discs, UK) and tetracycline $(10 \mu \mathrm{g})\left(\mathrm{OXOID}\right.$ discs, UK) were used as positive control. All the plates were incubated at $37^{\circ} \mathrm{C}$, for $18-24$ hours. After incubation, the antimicrobial activity was evaluated by measuring the inhibition zone diameter. Each test was performed twice and the average of the results was taken (Cotuk et al., 2005). 


\section{Results}

\section{Physicochemical Analysis}

The water and soil samples taken from the two designated sites of the dark zone of the Kadini Cave were analyzed. The air temperature measurements of the samples collected from Site 1 and Site 2 of the cave were $18.9^{\circ} \mathrm{C}$ and $17.5^{\circ} \mathrm{C}$ and the air humidity values were $92 \%$ and $86 \%$. The environmental parameters of the water samples in the Kadiini Cave are shown in Table 1. Conductivity, TDS and salinity values of the Site 1 were statistically higher than the Site 2 $(p<0.05)$.

Table 1. The Physico-Chemical parameters of the water samples from Kadıini Cave in December 2014.

\begin{tabular}{ccc}
\hline Parameters & Site 1 & Site 2 \\
\hline Water temperature $\left({ }^{\circ} \mathrm{C}\right)$ & 17.8 & 17.4 \\
$\mathrm{pH}$ & 7.87 & 8.82 \\
Conductivity $(\mu \mathrm{S} / \mathrm{cm})$ & 442 & 294 \\
$\operatorname{TDS}(\mathrm{mg} / \mathrm{L})$ & 211.5 & 140.3 \\
\hline
\end{tabular}

\section{Enumeration, isolation, and identification of cultur-} able bacteria from Kadini Cave

The levels of heterotrophic aerobic bacteria from Site 1 and Site 2 from the dark zone of the Kadini Cave are given in Table 2. The total (live + dead) and the live bacteria count (log cell/mL, log cell/g) of the water and soil samples are shown in Table 2. By using DAPI-CTC staining, we showed that the total viable bacterial count is higher than the cultured bacterial count.

Table 2. Total (live + dead), live bacteria count (log cell/mL, log cell/g), viability (\%) and total culturable aerobic heterotrophic bacteria of water and soil samples from Kadıini Cave in December 2014.

\begin{tabular}{ccccc}
\hline Bacteria Measures & Site 1 Water & Site 1 Soil & Site 2 Water & Site 2 Soil \\
\hline Total bacteria count $^{\mathrm{a}}$ & 10 & 10.6 & 7.8 & 11 \\
Live bacteria count $^{\mathrm{b}}$ & 9.8 & 10 & 7.6 & 37.5 \\
$\quad$ Viability (\%) $_{\text {Culturable aerobic heterotrophic }}^{\text {bacteria (log CFU) }}$ & 41.7 & 21 & 26.3 & $3.2 \pm 0.6$ \\
\hline
\end{tabular}

\footnotetext{
a Total bacteria' counts determined by DAPI + CTC staining
}

' Live bacteria' counts determined by CTC staining.

Fourty-five bacteria were isolated from the water and soil samples collected from Kadiini Cave. After amplification of the 16S rRNA gene for each isolate, three phylogenetic groups: Firmicutes (86\%), Proteobacteria (12\%) and Actinobacteria (2\%) were recorded. The composition of cultivable heterotrophic aerobic bacteria, the names and distribution percentage of the identified genera are shown in Table 3. After phylogenetic analysis, a strong domination of Gram-positive aerobic heterotrophic bacteria was established (89\%), belonging to four genera: Bacillus, Viridibacillus, Staphylococcus, and Brevibacterium. Gram-negative isolates (11\%) were represented by two genera: Pseudomonas and Paracoccus (Table 4).

\section{Biochemical characterization and enzyme profiles of the isolates}

Biochemical characterization and enzyme profiles of the bacilli (BCL and spore-forming) (Fig. 2), Gram positive (Fig. 3), and Gram negative (Fig. 4) isolates are determined as a result of the analyses conducted by using the automated micro identification system VITEK 2 Compact 30 (bioMerieux, France). Seventy-eight percent of all isolates have a positive reaction for production of the TyrA enzyme. The percentage of presence of PRY enzyme is found to be high in $\mathrm{BCL} /$ spores and GN strains. In addition, the percentage of ProA enzymes is higher in GN and GP strains. The positive reaction percentages of all isolates (BCL, GP, and $\mathrm{GN}$ ) against the tested substrates are displayed in Figures 2-4.

\section{Antimicrobial activity of the isolates}

The cave bacterial isolates were screened to understand their antimicrobial activities against $S$. epidermidis (ATCC 12228), B.subtilis (ATCC 6633), S.aureus (ATCC 6538), P.aeruginosa (ATCC 9027), E.coli (ATCC 8739), MRSA (ATCC 33591), and VRE (ATCC 51299) strains by the agar plug diffusion method. The commercial antibacterial agents were used against all tested standard strains (Table 5). In this study, seven bacteria, isolated from the water and soil samples, displayed antimicrobial activity (15.5\%) against the control bacteria.

\section{Discussion}

This cave is unexplored from the microbiological point of view, making it interesting to study the bacterial diversity for possible industrial applications. In this study, the total viable bacteria counts were recorded to be higher than the culturable bacteria counts in the samples collected from Kadini Cave. It was documented that many species of bacteria en- 
Table 3. The composition of cultivable heterotrophic aerobic bacteria and percentage distribution of the identified genus.

\begin{tabular}{cccc}
\hline Phylum & Class & Genus & $\%$ \\
\hline Firmicutes & Bacilli & Bacillus & 67 \\
& & Viridibacillus & 2 \\
& & Staphylococcus & 18 \\
Actinobacteria & Actinobacteria & Brevibacterium & 2 \\
Proteobacteria & Alphaproteobacteria & Paracoccus & 2 \\
& Gammaproteobacteria & Pseudomonas & 9 \\
\hline
\end{tabular}

Table 4. Closest match of the bacterial isolates based on 16S rRNA gene phylogeny analysis.

\begin{tabular}{|c|c|c|c|}
\hline $\begin{array}{l}\text { Isolation ID } \\
\text { (accession \#) }\end{array}$ & $\begin{array}{l}\text { Nearest relativea/ } \\
\text { Bacterial division }\end{array}$ & $\begin{array}{c}\text { Accession \# } \\
\text { (nearest relativea) }\end{array}$ & $\%$ Similarity \\
\hline 1 (MK491005) & Bacillus cereus & MH041184 & 99 \\
\hline 4 (MK491021) & Bacillus cereus & KY316431 & 99 \\
\hline 5 (MK491027) & Bacillus cereus & KX941839 & 99 \\
\hline 16 (MK491045) & Bacillus cereus & MG563677 & 99 \\
\hline 28 (MK491024) & Bacillus cereus & MG563677 & 98 \\
\hline 38 (MK491036) & Bacillus cereus & MG563677 & 98 \\
\hline 6 (MK491032) & Bacillus cereus & MG563677 & 99 \\
\hline 20 (MK491023) & Bacillus pumilus & KC182057 & 98 \\
\hline 30 (MK491035) & Bacillus pumilus & KF641848 & 98 \\
\hline 31 (MK491041) & Bacillus pumilus & HG799995 & 98 \\
\hline 39 (MK491042) & Bacillus pumilus & KF641848 & 99 \\
\hline 42 (MK491014) & Bacillus pumilus & KF641848 & 99 \\
\hline 46 (MK491037) & Bacillus pumilus & KF641848 & 98 \\
\hline 47 (MK491043) & Bacillus pumilus & KC182057 & 99 \\
\hline 50 (MK491015) & Bacillus pumilus & KY127313 & 98 \\
\hline 37 (MK491030) & Bacillus pumilus & KY127313 & 98 \\
\hline 11 (MK491016) & Bacillus niacini & KT720235 & 97 \\
\hline 14 (MK491033) & Bacillus litoralis & KU983814 & 98 \\
\hline 2 (MK491010) & Bacillus thuringiensis & LC146715 & 99 \\
\hline 22 (MK491034) & Bacillus toyonensis & KY649418 & 98 \\
\hline 33 (MK491008) & Bacillus amyloliquefaciens & СР018902 & 98 \\
\hline 24 (MK491046) & Bacillus weihenstephanensis & KF831381 & 99 \\
\hline 48 (MK491049) & Bacillus mycoides & MH169305 & 99 \\
\hline 32 (MK491047) & Bacillus subtilis & EU883786 & 99 \\
\hline 13 (MK491028) & Viridibacillus arvi & KU894793 & 99 \\
\hline 12 (MK491022) & Bacillus sp. & MG548383 & 99 \\
\hline 7 (MK491038) & Bacillus sp. & MH628022 & 99 \\
\hline 10 (MK491011) & Bacillus sp. & FJ348046 & 97 \\
\hline 21 (MK491029) & Bacillus sp. & KM108632 & 97 \\
\hline 34 (MK491013) & Bacillus sp. & КT316413 & 99 \\
\hline 25 (MK491007) & Bacillus sp. & MH698798 & 98 \\
\hline
\end{tabular}


Table 4. (Continued).

\begin{tabular}{cccc}
\hline $\begin{array}{c}\text { Isolation ID } \\
\text { (accession \#) }\end{array}$ & $\begin{array}{c}\text { Nearest relativea/ } \\
\text { Bacterial division }\end{array}$ & $\begin{array}{c}\text { Accession \# } \\
\text { (nearest relativea) }\end{array}$ & \% Similarity \\
\hline $\mathbf{3 5}$ (MK491019) & Staphylococcus warneri & HG799993 & KX453876 \\
$\mathbf{3 6}$ (MK491025) & Staphylococcus warneri & KX349994 & 96 \\
$\mathbf{1 7}$ (MK491006) & Staphylococcus warneri & KU922389 & 99 \\
$\mathbf{1 5}$ (MK491039) & Staphylococcus pasteuri & KU922319 & 98 \\
$\mathbf{1 9}$ (MK491017) & Staphylococcus pasteuri & KX926554 & 98 \\
$\mathbf{4 3}$ (MK491020) & Staphylococcus epidermidis & KX349995 & 99 \\
$\mathbf{4 0}$ (MK491048) & Staphylococcus epidermidis & EU177793 & 99 \\
$\mathbf{8}$ (MK491044) & Staphylococcus sp & MF716680 & 97 \\
$\mathbf{2 7}$ (MK491018) & Pseudomonas plecoglossicida & CP015992 & 97 \\
$\mathbf{4 4}$ (MK491026) & Pseudomonas sp. & KX301316 & 98 \\
$\mathbf{4 5}$ (MK491031) & Pseudomonas sp. & KX301316 & 99 \\
$\mathbf{4 9}$ (MK491009) & Pseudomonas sp & CP030239 & 98 \\
$\mathbf{2 3}$ (MK491040) & Paracoccus mutanolyticus & KU922165 & 99 \\
\hline
\end{tabular}

Based upon a Blast search of the NCBI database.

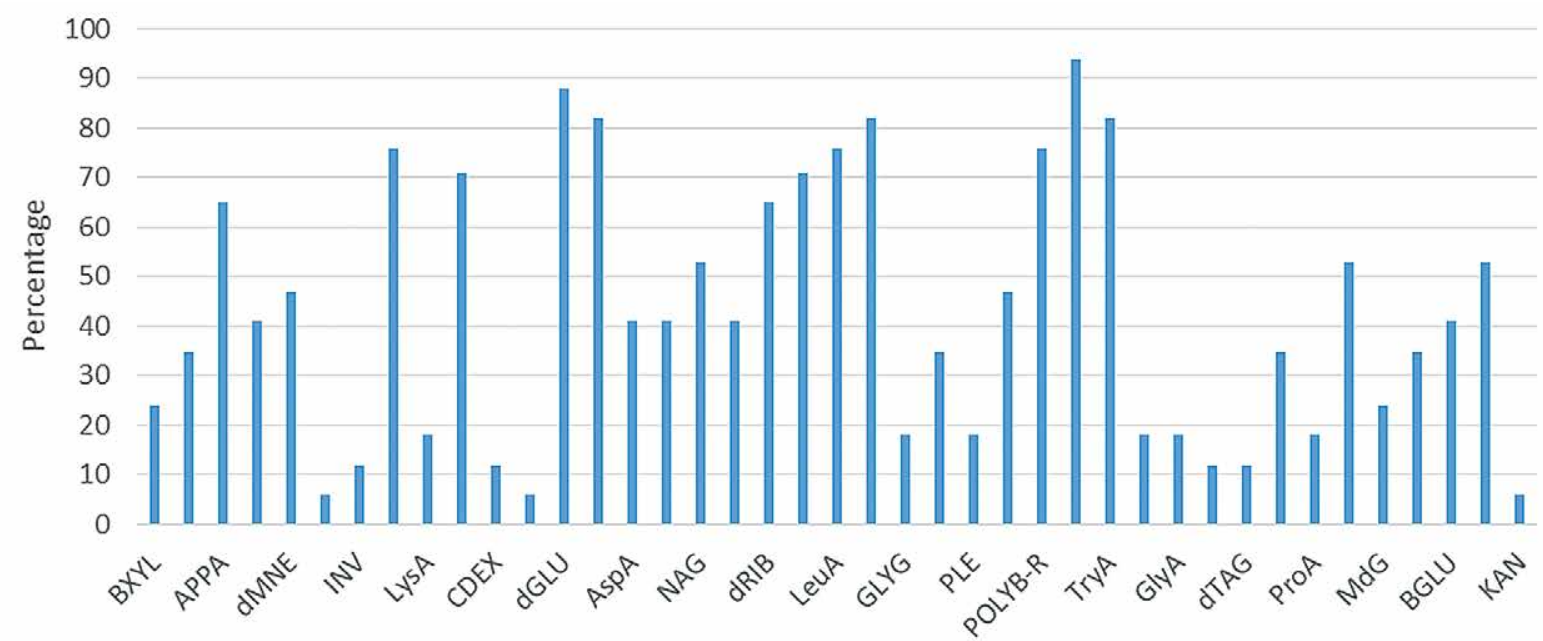

Enzymatic reactions

Figure 2. Biochemical characterization and enzyme profiles of the Gram-positive spore-forming bacilli (BCL) isolated from Kadini Cave. VBNC phase under these conditions. The VBNC phase is also described as the genetically programmed physiological response of bacterial cells that are fighting to survive under environmental stress (Besnard et al., 2002).

Conductivity is the capacity of water to conduct an electric current. At the same time it is an indirect measurement of salinity and total dissolved solids (TDS) content (AI Dahaan et al., 2016). In our study, it was determined that the conductivity, TDS and salinity values of Site 1 were statistically higher than Site $2(p<0.05)$. Conductivity, TDS and salinity are strongly related to the aquifer rock geochemistry (Bakalowicz 1994). These results may indicate that Site 2 is fed by a water source.

In our study, the microbial communities were dominated by the members of Firmicutes (85\%), followed by Proteobacteria (13\%) and Actinobacteria (2\%). These phyla are encountered in various microbiological studies conducted through culture-based or molecular techniques (Barton 2015). Firmicutes are frequently encountered under extreme conditions; 


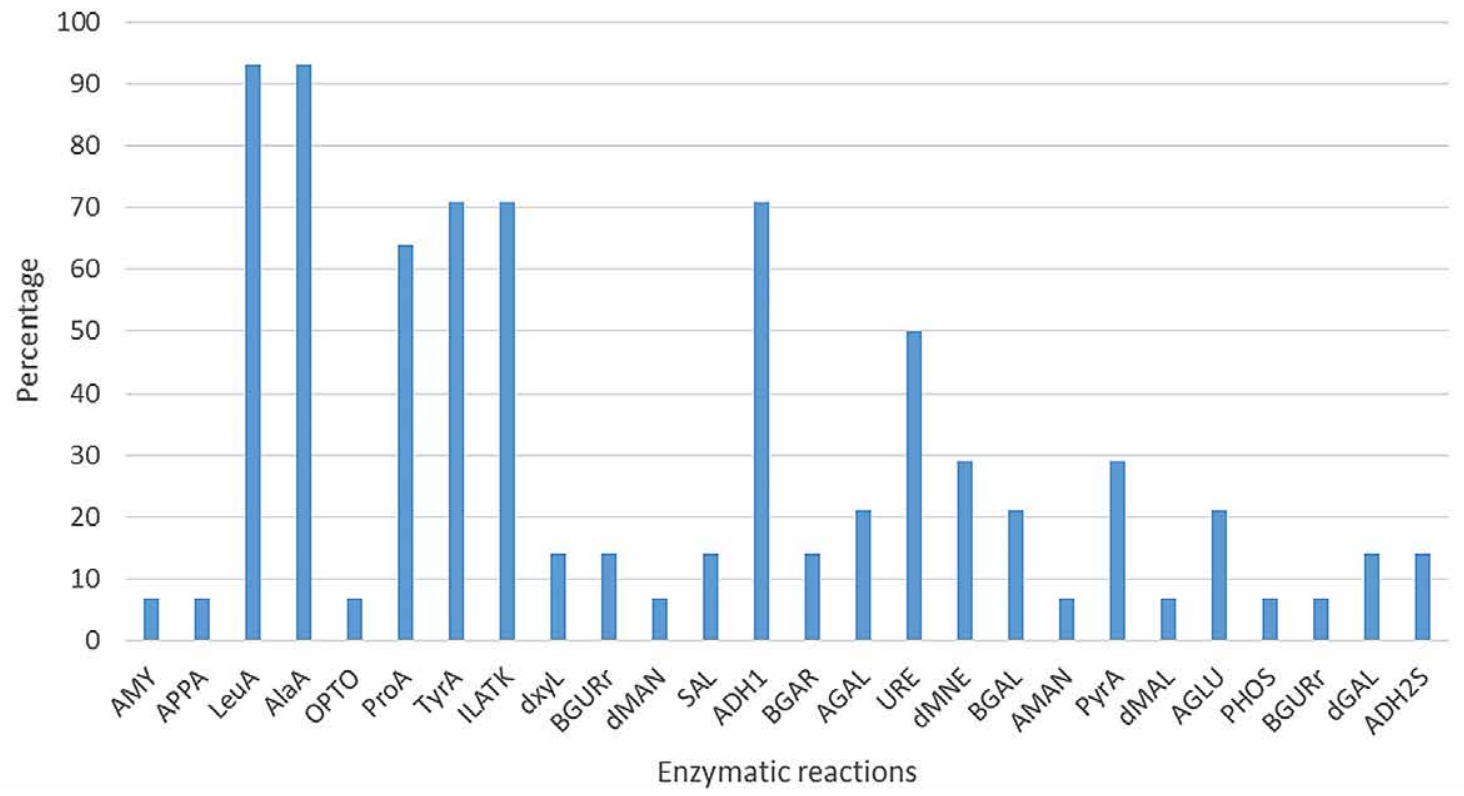

Figure 3. Biochemical characterization and enzyme profiles of the Gram-positive cocci and non-spore-forming bacilli (GP) isolated from Kadini Cave.



Enzymatic reactions

Figure 4. Biochemical characterization and enzyme profiles of the Gram-negative fermenting and non-fermenting bacilli (GN) isolated from Kadini Cave.

2009). In the present study, while Bacillus were the most common genera represented by nine species, Staphylococcus follow it as the second most common genera with three species. The most common species belonging to Bacillaceae family was Bacillus pumilus, followed by Bacillus cereus. Biochemical and biomolecular analyses showed that most calcifying strains are members of the genus Bacillus sp. and Pseudomonas sp. (Shirakawa et al., 2011, Banerjee and Joshi 2016). S.epidermidis, S. pasteuri and S.warneri isolated from Kadiini Cave belong to typical human and animal microbiota like S.aureus, these species are considered pathogens (Lavoie and Northup 2005; Mulec et al., 2017). These studies show that these bacteria are ubiquitous and have been previously identified in karstic caves (Herzog Velikonja et al., 2014; Ma et al., 2015; Banerjee and Joshi 2016; Iţcuş et al., 2016).

The types of microbial extracellular enzyme activities imply the kinds of nutrients present in that environment. Khizhnyak et al. (2003) reported that cultures from Siberian caves produced a low-level of amylolytic enzymes compared to other enzyms, which explains the abscence of natural sources of starch in these environment. In our study, it has been determined that $78 \%$ of all isolates could break the aril-amid bonds in tyrosine. Additionally, all Gram positive 
Table 5. The inhibition zones $(\mathrm{mm})$ of standard bacterial strains against experimental isolates and some antibiotics. (-) no inhibition.

\begin{tabular}{|c|c|c|c|c|c|c|c|}
\hline \multirow[b]{2}{*}{ Isolates (ID) } & \multicolumn{7}{|c|}{ Bacterial inhibition zones $(\mathrm{mm})$} \\
\hline & S.epidermidis & B.subtilis & S.aureus & P.aeruginosa & E.coli & MRSA & VRE \\
\hline Brevibacterium frigoritolerans ( 23 ) & 8 & 12 & - & - & - & - & - \\
\hline Bacillus thuringiensis ( 2) & 10 & 12 & - & - & - & - & - \\
\hline Bacillus weihenstephanensis ( 24 ) & 12 & 14 & - & - & - & - & - \\
\hline Bacillus cereus (28) & - & 8 & - & - & - & - & - \\
\hline Bacillus cereus (1) & 14 & 14 & - & - & - & - & - \\
\hline Bacillus sp. (12) & - & 10 & - & - & - & - & - \\
\hline Pseudomonas sp. (44) & - & - & 16 & - & - & 10 & - \\
\hline Erythromycin & $34(S)$ & $34(S)$ & $18(\mathrm{I})$ & - & 12 & - & - \\
\hline Vancomycin & $40(S)$ & $26(S)$ & $16(R)$ & - & - & $9(\mathrm{R})$ & $28(S)$ \\
\hline Neomycin & $18(I)$ & $24(S)$ & - & $10(R)$ & $10(\mathrm{R})$ & $14(R)$ & - \\
\hline Gentamicin & $24(S)$ & $32(S)$ & $16(S)$ & $22(S)$ & $22(S)$ & $20(S)$ & - \\
\hline Tetracyclin & $28(S)$ & $32(S)$ & $12(\mathrm{R})$ & $10(R)$ & $20(S)$ & - & $14(R)$ \\
\hline
\end{tabular}

isolates displayed positive arylamidases reaction that were specific for leucine and alanine at varying rates between $76 \%$ and $93 \%$. According to our results of the L-proline-arylamidase test, all of Gram-negative bacteria and $64 \%$ of Gram-positive bacteria were positive.

A range of enzymatic activities was found in bacteria from the Kadini Cave. Most of these enzymes have proteolytic activity, of which $96 \%$ of BCL isolates, $96 \%$ of GP isolates, and $100 \%$ of GN isolates produce at least one enzyme required for protein metabolism. Tomova et al. (2013) reported that $87 \%$ of Magura Cave isolates have proteolytic activity. Tyrosine residues formed by the breakdown of tyrosine by arylamidase and proline residues formed by the breakdown of L-Proline by arylamidase have very important metabolic functions for the cell in bacteria. They are effective in cell metabolic activities and formation of secondary metabolites (Patterson et al., 1963; Westley et al., 1967; Levit 1981; Kohl et al., 1988; Shibasaki et al., 1999; Nagata et al., 2003; Curtis et al., 2004; Whitmore and Lamont 2012). Because of their possession of different proteolytic enzymes, they can survive in environments such as caves that are poor in nutrients. Glycosidases are the most commonly found enzyme group after proteolytic enzymes in cave isolates. Our study has shown a positive proteolytic enzymes activity of the bacilli isolates, as well as the ones regarding carbonhytrate catabolism.

Antimicrobial components have a central part in mankind's struggle against infections. Nevertheless, because of their various resistance mechanisms, native or acquired, many antibiotics are losing their function every year (Kmietowicz, 2017). Nowdays, the existance of microorganisms with different enzymatic and antimicrobial effects has been proven in extreme ecosystems and researchers have started to focus on caves as one extreme environment (Lavoie, 2015; Man et al., 2015). Certain microorganisms isolated from cave ecosytems have been proven to display antimicrobial activity (Cheeptham et al., 2013; Tomova et al., 2013; Klusaite et al., 2016). Our results showed that $15.5 \%$ of the isolates have antimicrobial activity against B.subtilis and S.epidermidis and the others ineffective. In addition, isolate number 7 is effective against S.aureus and methicillin-resistant S.aureus. Yücel and Yamaç (2010) investigated 19 karstic caves in Turkey. They reported that the antibiotic extract that they obtained from these caves had bactericidal effect on the model resistant strains in lower concentrations than the antibiotic streptomycin. An important part of these secondary metabolites are potent antibiotics, which has made Bacillus one of the major antibiotic-producing organisms exploited by the pharmaceutical industry (Ghosh et al., 2017).

\section{Conclusions}

The bacteria isolated from Kadini Cave displayed a potential related for use not only products but also vegetative forms in biotechnological applications such as biodegredation, enzyme production, antimicrobial or antitumoral drugs, and bacterial self-healing concrete (Jariyal et al., 2015; Kanmani et al., 2015; Zhang et al., 2015; Lee and Park, 2018). In addition, research conducted in 2018 have used many bacterial species isolated from the Kadini Cave against phytopathogens and entomopathogen (Durairaj et al., 2018, Karungu et al., 2018).

In our study of the bacterial communities of Kadiini Cave, the antimicrobial activity and the biotechnological use potentials were investigated. The study results showed that the most commonly detected bacterial genus in cave 
ecosytem was Bacillus (Firmicutes). Although there were differences in the bacterial species detected in Kadiini Cave, our results indicated that Firmicutes, Proteobacteria and Actinobacteria are the most common group with biochemical peculiarities of the isolated bacteria against tested substrates. There is the biotechnological potentiality of these strains for further studies and industrial applications. The results obtained in our study contributed to understanding the heterotrophic aerobic culturable bacteria profile of karstic Kadıini Cave ecosytems regarding a source of industrially important enzymes and antimicrobial compounds.

\section{Acknowledgements}

The authors thank Istanbul University Scientific Project Unit (BAP Project FBA-2017-25580 and BEK-2017-27261) for their financial support. The author would like to thank the Anatolian Speleology Association, the Akdeniz University Cave Research Club and Ender USULOĞLU for sampling, mapping, and their contributions during this research.

\section{References}

Al Dahaan, S., Al-Ansari, N., Knutsson, S., 2016, Influence of groundwater hypothetical salts on electrical conductivity total dissolved solids: Engineering, v. 8, no.11, p. 823-830. https://doi.org/10.4236/eng.2016.811074.

Bakalowicz, M., 1994, Water Geochemistry: Water Quality and Dynamics, in Gibert, J., Danielopol, D.L., and Stanford, J.A., eds., Groundwater Ecology: Academic Pres, p. 97-127.

Banerjee, S., and Joshi, S., 2016, Culturable bacteria associated with the caves of Meghalaya in India contribute to speleogenesis: Journal of Cave and Karst Studies, v. 78, p. 144-157. https://doi.org/10.4311/2015mb0131.

Barton, H.A., 2015, Starving artists: Bacterial oligotrophic heterotrophy in caves: in Engel. A.S., and DeGruyter, W, eds., Life in Extreme Environments: Microbial Life of Cave Systems, Berlin, Germany, p. 79-95.

Besnard, V., Federighi, M., Declerq, E., Jugiau, F., and Cappelier, J.M., 2002, Environmental and physico-chemical factors induce VBNC state in Listeria monocytogenes: Veterinary Research, v. 33, p. 359-370. https://doi.org/10.1051/vetres:2002022.

Bontognali, T.R.R., D’Angeli, I.M., Tisato, N., Vasconcelos, C., Bernasconi, S.M., Gonzales E.R.G., and De Waele, J., 2016, Mushroom speleothems: stromatolites that formed in the absence of phototrops: Frontiers of Earth Science, v. 4, no. 49, p.1-8. https://doi.org/10.3389/feart.2016.00049.

Borda, D.R., Năstase-Bucur, R.M., Spînu, M., Uricariu, R., and Mulec, J., 2014, Aerosolized microbes from organic rich materials: Case study of bat guano from caves in Romania: Journal of Cave and Karst Studies, v. 76, p. 114-126. https://doi.org/10.4311/2013MB0116. https://doi. org/10.4311/2013MB0116.

Bhullar, K., Waglechner, N., Pawlowski, A., Koteva, K., Banks, E.D., Johnston, M.D., Barton H.A., Wright, G.D., 2012, Antibiotic resistance is prevalent in an isolated cave microbiome: PloS One, v. 7, no. 4, p. 1-11. https://doi:10.1371/journal .pone.0034953.

Cheeptham, N., Sadoway, T., Rule, D., Watson, K., Moote, P., Soliman, L.C., Azad, N., Donkor, K. K., and Horne, D., 2013, Cure from the cave: volcanic cave actinomycetes and their potential in drug discovery: International Journal of Speleology, v .42, p. 35-47. http://dx.doi. org/10.5038/1827-806X.42.1.5.

Coraman and Celik, 2012, Identification and Protection of Important Bat Caves in Turkey: Project final report, Project ID: 0534710.

Cotuk, A., Doğruöz, N., Zeybek, Z., Kimiran-Erdem A., and İlhan Sungur, E., 2005, The effects of Pseudomonas and Aeromonas strains on Legionella pneumophila growth: Annals of Microbiology, v. 55, p. 219-224.

Curtis, J., Shearer, G., and Kohl, D.H., 2004, Bacteroid proline catabolism affects N2 fixation rate of drought-stressed soybeans: Plant physiology, v. 136, no. 2, p. 3313-3318. https://doi/10.1104/pp.104.044024.

Doğruöz Güngör, N., and Sanli Yurudu, N.O., 2015, Evaluation of bacterial resistance to chloramine T biocide and effects on rifampicin antibiotic susceptibility as a consequence of biocide usage in Cooling System Biofilm including Legionella pneumophila: The Battle Against Microbial Pathogens, Basic Science, Technological Advances and Educational Programs, p.923-929

Durairaj, K., Velmurugan, P., Park, J.H., Chang, W.S., Park, Y.J., Senthilkumar, P., Choi, K.M., Lee, J.H., and Oh, B.T., 2018, An investigation of biocontrol activity Pseudomonas and Bacillus strains against Panax ginseng root rot fungal phytopathogens: Biological Control, v. 125, p. 138-146. https://doi.org/10.1016/j.biocontrol.2018.05.021.

Engel, A.S., 2010, Microbial diversity of cave ecosystem, in Barton, L.L, Mandi, M., Loy, and A. eds, Geomicrobiology, Molecular and Environmental Perspective: Springer Science and Business Media BV, p. 219-238. https://doi.org/10.1007/978-90-481-9204-5.

Engel, A.S., 2011, Karst Ecosystems, in Reitner, J., and Thiel, V. eds, Encyclopedia of Geobiology, Encyclopedia of Earth Sciences Series: Springer, Dordrecht, p. 521-531. https://doi.org/10.1007/978-1-4020-9212-1_125.

Ghosh, S., Kuisiene, N., and Cheeptham, N., 2017, The cave microbiome as a source for drug discovery: Reality or pipe dream?: Biochemical Pharmacology, v. 134, p. 18-34. https://doi.org/10.1016/j.bcp.2016.11.018.

Herzog Velikonja, B., Tkavc, R., and Pašić, L., 2014, Diversity of cultivable bacteria involved in the formation of macroscopic microbial colonies (cave silver) on the walls of a cave in Slovenia: International Journal of Speleology, v. 43, p. 45-56. https://doi.org/10.5038/1827-806x.43.1.5.

Iţcuş, C., Pascu, M.D., Brad, T., Perşoiu, A., and Purcarea, C., 2016, Diversity of cultured bacteria from the perennial ice block of Scarisoara Ice Cave, Romania: International Journal of Speleology, v. 45, p. 89-100. https://doi.org/10.5038/1827-806x.45.1.1948.

Jariyal, M., Gupta, V.K., Mandal, K., and Jindal, V., 2015, Brevibacterium frigoritolerans as a novel organism for the bioremediation of phorate: Bulletin of Environmental Contamination and Toxicology, v. 95, p. 680-686. https://doi.org/10.1007/s00128-015-1617-2.

Kanmani, P., Kumaresan, K., and Aravind, J., 2015, Utilization of coconut oil mill waste as a substrate for optimized lipase production, oil biodegradation and enzyme purification studies in Staphylococcus pasteuri: Electronic Journal of Biotechnology, v. 18, p. 20-28. https://doi. org/10.1016/j.ejbt.2014.11.003.

Karungu, S., Huang, D., Atoni, E., Waruhiu, C., Agwanda, B., Hu, X., and Yuan, Z., 2018, Isolation, identification, and evaluation of mosquito entomopathogenic Bacillus species and related genera from randomly selected sites in Kenya: African Journal of Microbiology Research, v. 12, p. 290-299. https://doi.org/10.5897/ajmr2018.8824.

Khizhnyak S.V., Tausheva I.V., Berezikova A.A., Nesterenko E.V, and Rogozin D.Y., 2003, Psychrophilic and psychrotolerant heterotrophic microorganisms of middle Siberian karst cavities: Russian Journal of Ecology, v. 34, p. 231-235.

Klusaite, A., Vickackaite, V., Vaitkeviciene, B., Karnickaite, R., Bukelskis, D., Kieraite-Aleksandrova, I., and Kuisiene, N., 2016, Characterization of antimicrobial activity of culturable bacteria isolated from Krubera-Voronja Cave: International Journal of Speleology, v. 45, p. 8. https://doi. org/10.5038/1827-806x.45.3.1978. 
Kmietowicz, Z., 2017, Few novel antibiotics in the pipeline, WHO warns, BMJ: British Medical Journal (Online), BMJ 2017: 358: j4337. https://doi. org/10.1136/bmj.j4339.

Kohl, D.H., Schubert, K.R., Carter, M.B., Hagedorn, C.H., and Shearer, G., 1988, Proline metabolism in N2-fixing root nodules: energy transfer and regulation of purine synthesis: Proceedings of the National Academy of Sciences, v. 85, no. 7, p. 2036-2040. https://doi.org/10.1073/ pnas.85.7.2036.

Lavoie, K.H., 2015, A grand, gloomy, and peculiar place: Microbiology in the Mammoth Cave Region: Life in Extreme Environments: Microbial Life of Cave Systems: Engel, AS, Ed, De Gruyter, Berlin, Germany, p. 47-78. https://doi.org/10.1515/9783110339888-005.

Lavoie, K.H., and Northup, D.E., 2005, Bacteria as indicators of human impact in caves: National Cave and Karst Management Symposium, p. 40-47.

Lee, Y. S., and Park, W., 2018, Current challenges and future directions for bacterial self-healing concrete: Applied Microbiology and Biotechnology, v. 102, p. 3059-3070. https://doi.org/10.1007/s00253-018-8830-y.

Levitt, M., 1981, Effect of proline residues on protein folding: Journal of molecular biology, v. 145, no. 1, p. 251-263. https://doi.org/10.1016/00222836(81)90342-9.

Ma, Y., Zhang, H., Du, Y., Tian, T., Xiang, T., Liu X., Wu, F., An, L., Wang, W., 2015, The community distribution of bacteria and fungi on ancient wall paintings of the Mogao Grottoes: Scientific Reports, v. 5, p. 7752. https://doi.org/10.1038/srep07752.

Man, B., Wang, H., Xiang, X., Wang, R., Yun, Y., and Gong, L., 2015, Phylogenetic diversity of culturable fungi in the Heshang Cave, central China: Frontiers in Microbiology, v. 6, no. 1158, p. 1-11. https://doi.org/10.3389/fmicb.2015.01158.

Mulec, J., Oarga-Mulec, A., Šturm, S., Tomazin, R., Matos, T., 2017, Spacio-temporal distribution and tourist impact on airborne bacteria in a cave (Škocjan Caves, Slovenia): Diversity, v .9, no. 28, p. 1-14. https://doi.org/10.3390/d9030028.

Nagata, K., Nagata, Y., Sato, T., Fujino, M.A., Nakajima, K., and Tamura, T., 2003, L-Serine, D-and L-proline and alanine as respiratory substrates of Helicobacter pylori: correlation between in vitro and in vivo amino acid levels: Microbiology, v. 149, no. 8, p. 2023-2030. https://doi. org/10.1099/mic.0.26203-0.

Northup, D.E., and Lavoie, K.H., 2001, Geomicrobiology of caves: a review: Geomicrobiology Journal, v. 18, p. 199-222. https://doi. org/10.1080/01490450152467750.

Palmer, A.N., 1991, Origin and morphology of limestone caves: Geological Society of America Bulletin, v. 103, p. 1-21. https://doi.org/10.1130/0016-7606(1991)103<0001:oamolc>2.3.co;2.

Patterson, E.K., Hsiao, S.H., and Keppel, A., 1963, Studies on Dipeptidases and Aminopeptidases I. distinction between leucine aminopeptidase and enzymes that hydrolyze I-leucyl- $\beta$-naphthylamide: Journal of Biological Chemistry, v. 238, no. 11, p. 3611-3620.

Pincus, D.H., 2005, Microbial Identification Using the BioMerieux Vitek® 2 System, in Encyclopedia of Rapid Microbiological Methods, Miller, M.J., ed., Parenteral Drug Association \& Davis Healthcare International Publishing, Moore, OK, 2005; v. II, p. 1-32.

Portillo, M.C., Saiz-Jimenez, C., and Gonzalez, J.M., 2009, Molecular characterization of total and metabolically active bacterial communities of 'white colonization' in the Altamira Cave, Spain: Research in Microbiology, v. 160, p. 41-47. https://doi.org/10.1016/j.resmic.2008.10.002.

Reasoner, D.J., and Geldreich, E.E., 1985, A new medium for the enumeration and subculture of bacteria from potable water: Applied Environmental Microbiology, v. 49, p. 1-7.

Romero, A., 2009, Cave Biology: Life In Darkness, Cambridge University Press, p. 159-181. https://doi.org/10.1017/CBO9780511596841.

Schwartz, T., Hoffmann, S., Obst, U., 2003, Formation of natural biofilms during chlorine dioxide and u.v. disinfection in a public drinking water distribution system: Journal of Applied Microbiology, v. 95, p. 591-601. https://doi:10.1046/j.1365-2672.2003.02019.x.

Shibasaki, T., Mori, H., Chiba, S., and Ozaki, A., 1999, Microbial proline 4-hydroxylase screening and gene cloning: Applied Environmental Microbiology, v. 65, no. 9, p. 4028-4031. https://doi.org/0099-2240/99/\$04.0010.

Shirakawa, M.A., Cincotto, M.A., Atencio, D., Gaylarde, C.C., and John, V.M., 2011, Effect of culture medium on biocalcification by Pseudomonas putida, Lysinibacillus sphaericus and Bacillus subtilis: Brazilian Journal of Microbiology, v. 42, p. 499-507. https://doi.org/10.1590/s151783822011000200014.

Slepecky, R.A., and Hemphill, H.E., 1992, The genus Bacillus-nonmedical: The Prokaryotes, 2nd ed., Springer Verlag, NY; v. III, p 1663. https://doi.org/10.1007/0-387-30744-3_16.

Tisato, N., Torriani, S.F.F., Monteux, S., Sauro, F., De Waele, J., Tavagna, M.L., D’Angeli I.M., Chailloux, D., Renda, M., Eglinton, T.I., and Bontognali, T.R.R., 2015, Microbial mediation of complex subterranean mineral structures: Scientific Reports, v. 5, p. 15525. https://doi. org/10.1038/srep15525.

Tomczyk-Żak, K., and Zielenkiewicz, U., 2015, Microbial diversity in caves: Geomicrobiology Journal, v. 33, p. 20-38. https://doi.org/10.1080/014 90451.2014 .1003341$.

Tomova, I., Lazarkevich, I., Tomova, A., Kambourova, M., and Vasileva-Tonkova, E., 2013, Diversity and biosynthetic potential of culturable aerobic heterotrophic bacteria isolated from Magura Cave, Bulgaria: International Journal of Speleology, v. 42, p. 65-76. https://doi.org/10.5038/1827-806x.42.1.8.

Turkey Cave Database. https://taban.magara.org [accessed: August 15, 2019].

Trevors, J.T., 2011, Viable but non-culturable (VBNC) bacteria: gene expression in planktonic and biofilm cells: Journal of microbiological methods, v. 86, no. 2, p. 266-273. https://doi.org/10.1016/j.mimet.2011.04.018.

Westley, J.W., Anderson, P.J., Close, V.A., Halpern, B., and Lederberg, E.M., 1967, Aminopeptidase profiles of various bacteria: Applied Environmental Microbiology, v.15, no. 4, p. 822-825.

Whitmore, S.E., and Lamont, R.J., 2012, Tyrosine phosphorylation and bacterial virulence: International journal of oral science, v. 4, 1-6. https:// doi/10.1038/ijos.2012.6.

Yılmazusta, N.D., Yakutipekoğlu, H., 2019, An Anthropological Assessment About Burial Practices of Kadıini Cave People (Alanya/Antalya): The Journal of Mediterranean Civilisations Research Institute (MCRI) Cedrus VII, p. 41-58. https://doi.org/10.13113/CEDRUS.201902.

Yücel, S., and Yamaç, M., 2010, Selection of Streptomyces isolates from Turkish karstic caves against antibiotic resistant microorganisms: Pakistan Journal of Pharmacological Science, v. 23, no. 1, p. 1-6.

Zhang, L., Liu, M., Jamil, S., Han, R., Xu, G., and Ni, Y., 2015, PEGylation and pharmacological characterization of a potential anti-tumor drug, an engineered arginine deiminase originated from Pseudomonas plecoglossicida: Cancer Letters, v. 357, p. 346-354. https://doi.org/10.1016/j. canlet.2014.11.042 
Nihal Doğruöz-Güngör, Elif Özlem Arslan-Aydoğdu, Emrah Dirmit, and Ender Usuloğlu. Anthropogenic impacts on the bacterial profile of Yarik Sinkhole in Antalya, Turkey. Journal of Cave and Karst Studies, v. 82, no. 2, p. 116-124. DOI:10.4311/2019MB0147

\title{
ANTHROPOGENIC IMPACTS ON THE BACTERIAL PROFILE OF YARIK SINKHOLE IN ANTALYA, TURKEY
}

\author{
Nihal Doğruöz-Güngör ${ }^{1, ~ c}$, Elif Özlem Arslan-Aydoğdu', Emrah Dirmit², and Ender Usuloğlu ${ }^{3}$
}

\begin{abstract}
Yarık Sinkhole is a vertical cave with a length of $1378 \mathrm{~m}$ and depth of $533 \mathrm{~m}$. Its location was marked by The Anatolian Speleology Association in 2011, and expedition entries started in 2014. Yarık Sinkhole became the $12^{\text {th }}$ deepest cave of Turkey. The aim of this study was to determine the bacterial profile of the Yarık Sinkhole using next generation metagenomic sequencing and to investigate whether the bacterial profile of the cave is affected by the activities of people living in this region. This study is important as the samples were collected during the first entrance of the exploration of the cave (up to $300 \mathrm{~m}$ ). The samples were collected from depths of $-80 \mathrm{~m},-120 \mathrm{~m}$ and $-300 \mathrm{~m}$. A total of 33 OTUs (Operational Taxonomic Unit) contained 4 bacteria phyla. Only Firmicutes, Proteobacteria and Actinobacteria phyla comprised a mean abundance of more than $1 \%$ in each sample. However, 18 different species have been detected in the Yarık Sinkhole. The most predominant species are Acinetobacter Iwoffii, Methylobacterium tardum, and Propionibacterium acnes. Although the sampling was done during the first exploration of the Yarık Sinkhole, the fact that the majority of bacteria found in the cave are human-associated, suggest serious impacts from people living near this cave from runoff with human and animal waste and trash.
\end{abstract}

\section{Introduction}

Caves are a subsurface habitat that are not explored as much with regard to biodiversity and community composition because of some environmental and geographical limitations. Natural caves generally involve an ecosystem that has a high humidity, limited nutritional sources, and a usually stable temperature, which are stable characteristics of a natural laboratory in terms of bacteria and their metabolic processes. Such environments are habitats only to those microorganisms that are specialized for the conditions in question. Therefore, natural caves are recognized as extreme environments (Palmer, 1991; Northup and Lavoie, 2001; Tomczyk-Żak and Zielenkiewicz, 2016). Microbial communities in caves are often highly variable dependent on the microenvironment. The range of bacterial diversity and composition are determined to be related to the geochemistry of host rocks (Barton et al., 2007). Nutrients also contribute to cave microbial diversity. Organic matter and microorganisms could be carried in to caves by air currents, seepage water, floods, seasonality, and animal/human activities (Shabarova et al., 2013).

The most appropriate way to unearth the bacterial diversity of a cave is to perform sampling at the time of exploration of the cave. Thus, the original microbiological diversity of the cave can be more realistically discovered by sampling before contamination associated with the cavers. However, the conditions may vary depending on the location and surroundings of the caves in terms of human impacts. Numerous cave microbiology studies have been carried out in the world. Since each cave is unique, these studies do not lose their importance (Busquets et al., 2014; De Mandal et al., 2014; Herzog Velikonja et al., 2014; Kieraite-Aleksandrova et al., 2015; Riquelme et al., 2015; Leuko et al., 2017).

It is estimated on the basis of the studies conducted in karstic areas that there are approximately 40,000 caves in Turkey (General Directorate of Mineral Research and Exploration). Cave microbiology studies from Turkish cave include: Yücel and Yamaç (2007), investigated the antimicrobial activity of Streptomyces spp. isolates from 19 different caves. In addition, characterization and definition of bacteria contributing to the formation of dripstone in Yıldızkaya cave systems in Erzurum have been studied by Barış (2009). Gulecal-Pektas and Temel (2017) studied the bacterial diversity and taxonomic composition of the Oylat Cave in Bursa and the Kaklık Cave in Denizli with poor oxygen, high temperature, and sulfur conditions. Even though the number of studies on microbiology in the caves of Turkey has been increasing, these studies are insufficient when the estimated number of caves is taken into account.

The culture technique is not sufficient on its own for determining the microbiological diversity of a cave. The rate of culturable bacteria in environments that contain complex microorganisms is only $0.1-1 \%$ of the total number due to their specific nutritional requirements (Torsvik and Øvreas, 2002). With the application of molecular methods, it was revealed that nutrient-poor caves had a surprisingly rich bacterial diversity. Metagenomics is a technique to access far more microbial diversity directly from environmental samples. Next-generation sequencing is cost-effective and provi-

${ }^{1}$ Istanbul University, Faculty of Science, Department of Biology, 34134 Vezneciler, Istanbul, Turkey

${ }^{2}$ Koza Gold Operations Company, 06370 Batıkent, Ankara

${ }^{3} 49$ Street Bradford Unit 2 Watertown Massachusetts USA

cCorresponding author: Nihal Doğruöz-Güngör ndogruoz@istanbul.edu.tr 
des more detailed taxonomic profiles between samples to be determined (Nelson el al., 2014). It has been shown that some microorganisms isolated by using culture methods were not detected by the molecular methods, and vice versa, which it has demonstrated that cultivation methods remain critical in microbial diversity studies (Donachie et al. 2007).

The Yarık Sinkhole is one of the caves which differ by its location in environmental conditions. During the summer months, the presence of people who are living there, as well as those who practice animal husbandry (approximately 30-50 people and 400 animals) are noticed. There are also tiny siphons where waters join the cave at both the main entrance of the Yarık Sinkhole and at different points deeper into the cave. In this study, we collected soil samples from three different points of the first-explored part of the cave, to both examine the bacteria profile, and, by means of the next-generation sequencing method, showed the impact of the anthropogenic effects on the cave's bacterial diversity.

\section{Site Description}

\section{Geology}

Yarık Sinkhole (GPS coordinate: UTM 448068.47 E 4036006.77 N) is located on the Sivastı Plateau that is centered $30 \mathrm{~km}$ north of Gazipaşa (Fig. 1) and is named with a specially-assigned geological sequence as the Sivastı formation. This formation, which is 2000-meters high, is one of the parts of the Taşeli Plateau.The study area, thought to be from the earliest Triassic age, has a complex structure with various orogenic movements such as Hershey and Alpen that undergo bending and fracturing. There are stratified schists and limestones at the Sivastı formation. Due to the different physical characteristics of the lithology, the schists are more curled and the limestones are more broken (Ulu, 1983).

A cross-sectional view of the cave map placed on the topography is presented in Figure 2. Yarık Sinkhole has a total length of $1378 \mathrm{~m}$ and $533 \mathrm{~m}$ depth. The first entrance to the cave was explored up to a depth of $300 \mathrm{~m}$ (Fig. 3). In 2016, the cave discovery reached a depth of $533 \mathrm{~m}$. Yarık Sinkhole became the 12th deepest cave of Turkey. The entrance to the cave has a wide mouth created by fracture hence its name; Yarık in Turkish means fracture (Fig.4). The watershed of the Yarık Sinkhole is a closed valley where the main rock is limestone with little sediment on the basin of the valley. There is no vegetation except for some trees planted by villagers for shade.

Despite a wide opening, there are occasional narrow passages in the cave and a rapid downward descent is characteristic of this cave. When the cross section map of the cave is viewed after the bench, downward declination

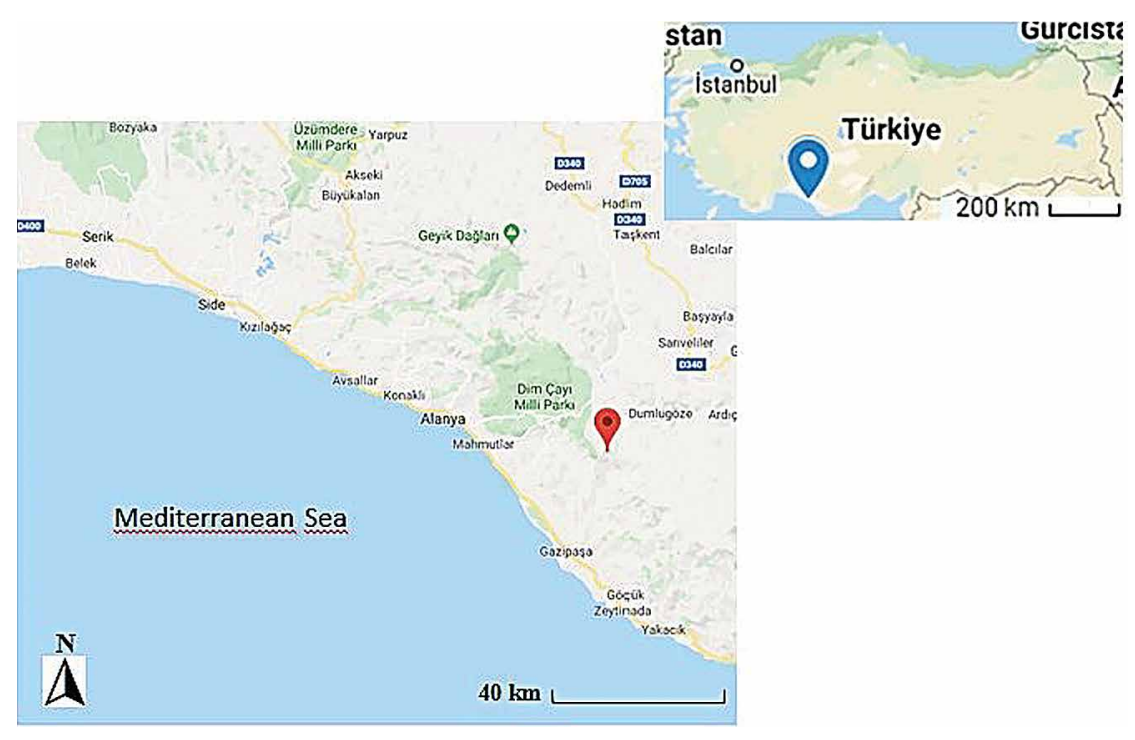

Figure 1. Yarık sinkhole location source [Google (Googlemaps, 2019)]. slowly gives away to horizontal passages with small ponds and lakes in them. The resulting bench size ranges from $5 \mathrm{~m}$ to $40 \mathrm{~m}$ on average. These benches generally formed as a result of active faults and fractures developed over time. The Yarık Sinkhole ceiling is high generally, but some of the narrow passages are difficult to pass, especially in the case of a flood when these passages will be totally blocked. Unlike most vertical caves, in the Yarık Sinkhole speleothems such as flowstones and cave pearls are found in the horizontal portion.

However, there are not any attempts to enter the entrance of the Yarık Sinkhole by the villagers as it will be fatal since the entrance is an 80 -meter shaft. Water only flows during the melting of ice in the spring. The cave camp area is 50-meters away from the entrance in a small pasture surrounded with seasonal settlements. The area is filled up with ice and snow in winter and in spring time meltwater is siphoned through a small pit with sediment at the bottom. The waste of livestock also goes along with the water.

The impact of population can be explained by the settlers in that valley. Additional side galleries within Yarık Sinkhole carry water from other watershed areas where there are additional people. Even though the impact cannot be measured, it is evident by the garbage that we have found deep in the cave which can not come only from the main entrance. 

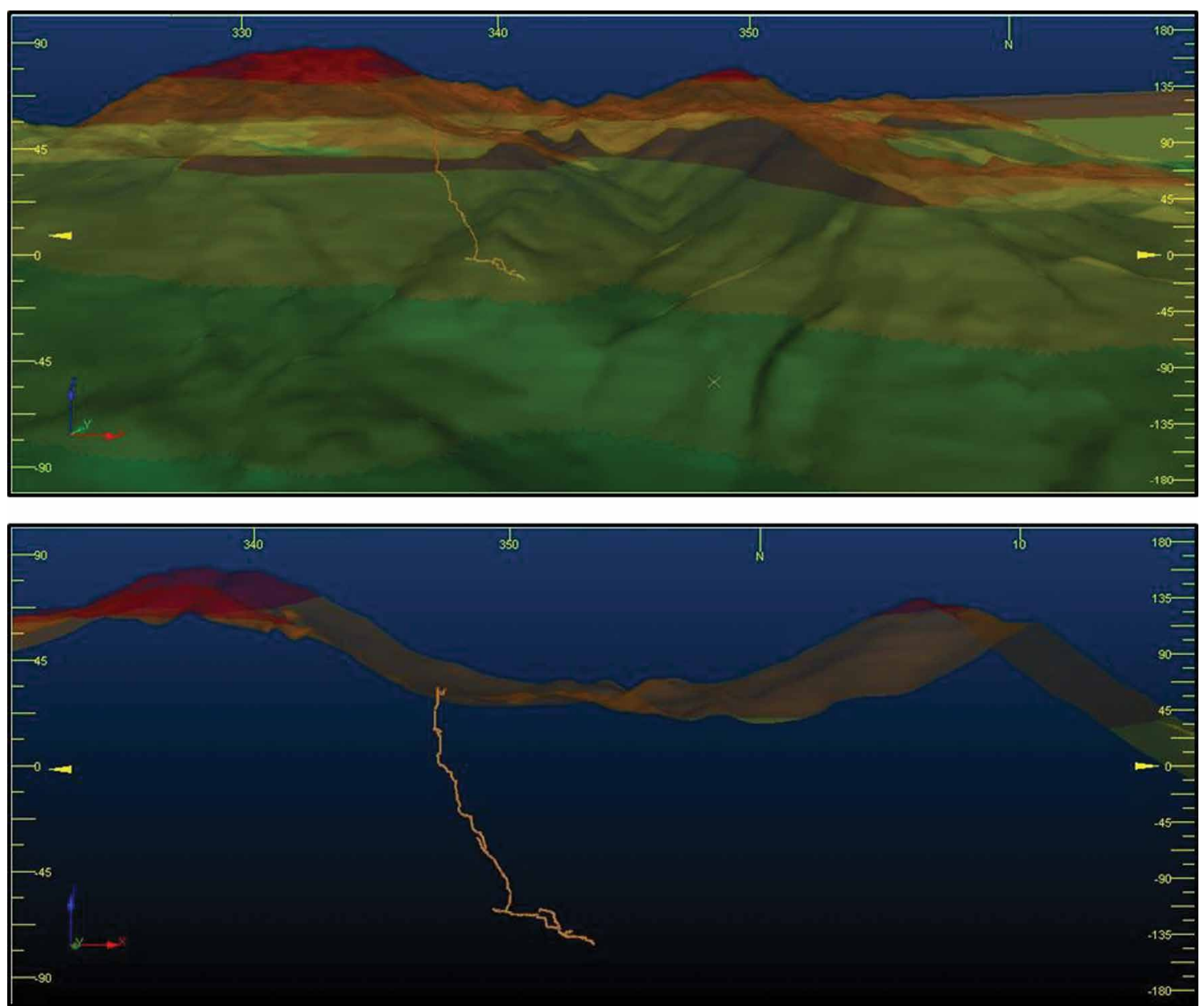

Figure 2. Cross-section view of topography (a) and Yarık Sinkhole's map (b) from The Anatolian Speleology Association(ASPEG).



Figure 3. Plan and profile of Yarık Sinkhole and sampling points from the Anatolian Speleology Association (ASPEG).
MATERIALS AND METHODS

Sampling and Physical-chemical analysis

The soil samples were taken from depths of $-80 \mathrm{~m},-120 \mathrm{~m}$ in June 2014 and $-300 \mathrm{~m}$ in August 2014, in parallel with the exploration of the cave. Approximately 10 $\mathrm{g}$ of soil was collected aseptically for microbial analysis from each sampling site in the cave. The samples were maintained at $4{ }^{\circ} \mathrm{C}$ and transported within 24 hours to the laboratory. The temperature and humidity of the sampling area were measured by a portable Temperature/ Humidity Meter (TFA 31.1028).

The water sample was taken in a pool from Yarık Sinkhole (-100 m depth) for hydrochemical characteristics in June 2014. The chemical analysis $\left(\mathrm{HCO}_{3}{ }^{-}, \mathrm{F}^{-}, \mathrm{Ca}^{2+}\right.$, $\mathrm{Cl}^{-}, \mathrm{Mg}^{2+}, \mathrm{K}^{+}, \mathrm{Na}^{+}$, and $\mathrm{SO}_{4}{ }^{2-}$ ) of the water sample were carried out according to different standard methods (Table 1) (APHA, 1992). 


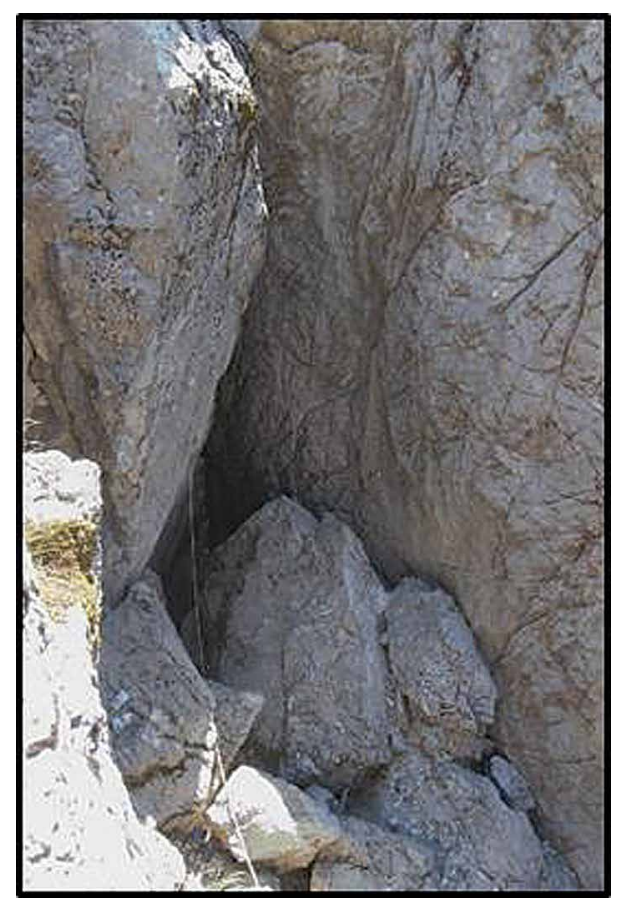

Figure 4. Yarık Sinkhole Entrance (about 10-meters long and 5-meters wide).

\section{DNA extraction}

DNA was extracted from $0.3 \mathrm{~g}$ (wet weight) of soil by using the Fast DNA Spin Kit for soil from Q-Biogene (Heidelberg, Germany) according to the manufacturer's instructions.

\section{S rRNA Metagenomic Sequencing Library Preparation and Sequenc- ing}

The microbial diversity at three depths was evaluated by using the Illumina MiSeq next generation sequencing approach (Novogene). The protocol includes the primer pair sequences for the $\mathrm{V} 3$ and $\mathrm{V} 4$ region of the 16S rRNA that create a single amplicon of approximately $460 \mathrm{bp}$ (Klindworth et al., 2013). The protocol also includes overhang adapter sequences that must be appended to the primer pair sequences for compatibility with Illumina index and sequencing adapters. Illumina adapter overhang nucleotide sequences-16S rRNA specific sequences were 5'TCGTCGGCAGCGTCAGATGTGTATAAGAGACAG-CCTACGGGNGGCWGCAG-3' for the forward primer and 5'-GTCTCGTGGGCTCGGAGATGTGTATAAGAGACAG-GACTACHVGGGTATCTAATCC-3' for the reverse primer. The first PCR was performed using BiospeedyTM Proof Reading DNA Polymerase 2x Reaction Mix (Bioeksen Ltd Co., Turkey) and $200 \mathrm{~nm}$ of each primer. The following program was performed on Biorad CFX Connect Instrument (Bio-Rad Laboratories, U.S.A.): $95^{\circ} \mathrm{C}$ for 3 minutes; 25 cycles of $95^{\circ} \mathrm{C}$ for 30 seconds, $55^{\circ} \mathrm{C}$ for 30 seconds and $72^{\circ} \mathrm{C}$ for 30 seconds; $72^{\circ} \mathrm{C}$ for 5 minutes. The PCR product was run on an agarose gel to verify the size ( $550 \mathrm{bp})$ and purified using BiospeedyTM PCR Product Purification Kit (Bioeksen Ltd. Co., Turkey).

The dual indices and Illumina sequencing adapters were attached to the purified first PCR products via the second PCR that was run using the Nextera XT Index Kit (Illumina Inc., USA) and the following program: $95^{\circ} \mathrm{C}$ for 3 minutes; 8 cycles of $95^{\circ} \mathrm{C}$ for 30 seconds, $55^{\circ} \mathrm{C}$ for 30 seconds and $72^{\circ} \mathrm{C}$ for 30 seconds; $72^{\circ} \mathrm{C}$ for 5 minutes. The PCR products were purified using BiospeedyTM PCR Product Purification Kit (Bioeksen Ltd. Co., Turkey). The final library was run on a Bioanalyzer DNA 1000 chip to verify the size ( 630 bp). The final library was diluted using $10 \mathrm{mM}$ Tris pH 8.5 to $4 \mathrm{nM}$ and the $5 \mu \mathrm{L}$ aliquots were mixed for pooling the libraries. In preparation for cluster generation and sequencing, pooled libraries were denatured with $\mathrm{NaOH}$, diluted with hybridization buffer $(\mathrm{HT} 1)$, and then heat denatured before MiSeq sequencing. Illumina MiSeq v3 reagent kits were used for the runs. Each run included a minimum of $5 \%$ PhiX to serve as an internal control.

\section{Bioinformatic Analysis}

The raw sequence data (concatenated forward and reverse sequence reads) were cleaned, reduced, and analyzed using Mothur Version 1.36.1. First, the barcode and the primer sequences were trimmed and then unique sequences were identified. The trimmed unique sequences were aligned to the SILVA rRNA database sequences using blastn algorithm (Pruesse et al., 2007). Before this the SILVA database sequences were trimmed to include only the V3-V4 region. The overhangs at both ends were removed via filtering the sequences and the redundancy check was carried out. For further de-nosing, the sequences were pre-clustered. The chimeras were eliminated using the implanted code UCHIME (Edgar et al., 2011). The sequences were classified by using Bayesian classifier implanted in Mothur. The reference and taxonomy files were adopted from the SILVA database (Pruesse et al., 2007). After Operational Taxonomic Unit (OTU) picking and their taxonomic assignment using the SILVA rDNA database, the OTUs were binned into phylotypes.

\section{Sequence Accession Numbers}

The raw sequencing data generated in this study were deposited into the NCBI database under accession numbers SRP123547 in the NCBI Sequence Read Archive, with the following accession numbers: SRS2657311, SRS2657312, and SRS2657313.

\section{Results}

\section{Physical-chemical environment}

The chemical characteristic of the water sample is presented in Table 1. The concentration in $\mathrm{Ca}^{2+}$ was found to exceed that of $\mathrm{Mg}^{+}$, whereby the predominant anion was determined to be $\mathrm{HCO}_{3}^{-}$. The mean air temperature and humidity inside the Yarık Sinkhole were $12.4^{\circ} \mathrm{C}$ and $94 \%$ respectively. 
Table 1. Parameters and test methods for chemical analysis of the Yarık Sinkhole water.

\begin{tabular}{|c|c|c|c|c|}
\hline Parameter & Unit & $\begin{array}{l}\text { Yarık Sinkhole } \\
\text { Water Sample }\end{array}$ & Test Method & Reference \\
\hline $\mathrm{HCO}_{3}^{-}$ & $\mathrm{mg} / \mathrm{L}$ & 124 & SM 2320 B & APHA (1992) \\
\hline $\mathrm{F}^{-}$ & $\mathrm{mg} / \mathrm{L}$ & 0.25 & SM 4500-F D & APHA (1992) \\
\hline $\mathrm{Ca}^{2+}$ & $\mathrm{mg} / \mathrm{L}$ & 35.7 & EPA 200.7 & APHA (1992) \\
\hline $\mathrm{Cl}^{-}$ & $\mathrm{mg} / \mathrm{L}$ & 5 & $\mathrm{SM} 4500 \mathrm{Cl}^{-} \mathrm{B}$ & APHA (1992) \\
\hline $\mathrm{Mg}^{2+}$ & $\mathrm{mg} / \mathrm{L}$ & 7.22 & EPA 200.7 & APHA (1992) \\
\hline $\mathrm{Na}+$ & $\mathrm{mg} / \mathrm{L}$ & 1.96 & EPA 200.7 & APHA (1992) \\
\hline $\mathrm{K}+$ & $\mathrm{mg} / \mathrm{L}$ & 0.74 & EPA 200.7 & APHA (1992) \\
\hline $\mathrm{SO}_{4}{ }^{2-}$ & $\mathrm{mg} / \mathrm{L}$ & 15.5 & $\mathrm{SM} 4500 \mathrm{SO}_{4}^{-2} \mathrm{E}$ & APHA (1992) \\
\hline $\mathrm{pH}$ & $\cdots$ & 7.42 & TS EN ISO 10523 & TSE (1999) \\
\hline Conductivity & $\mu S / \mathrm{cm}$ & 222 & TS 9748 EN 27888 & TSE (1996) \\
\hline
\end{tabular}

Bacterial taxonomy and distribution

Taxonomic assignment of 130,703 sequencing reads (Phred score $\geq 30$; Mean read length $>300 \mathrm{bp}$ ) from Yarık Sinkhole was obtained by targeting the $\mathrm{V} 3$ and $\mathrm{V} 4$ region of the bacterial $16 \mathrm{~S}$ rRNA gene. A total of 33 OTUs (based on $97 \%$ cutoff) comprising 4 bacterial phyla were found. The variation of the fractions of the phyla according to the depths was shown in (Table 2). Only Firmicutes, Proteobacteria,

and Actinobacteria phyla had a mean abundance of more than $1 \%$ in each sample holding more than $98 \%$ of the total sequence reads. The bacterial phylum with the highest presence percentage is Proteobacteria (average $80 \%$ ) at all the depths. It is followed by Actinobacteria (average 16\%). While the rate of presence of Firmucutes is more than $5 \%$ at $-300 \mathrm{~m}$, it is smaller than $1 \%$ at other depths. Bacteroidetes were found at less than $1 \%$ at other depths (Table 2 ).

At the class level, Gammaproteobacteria (average 17\%) was present at all the depths. Alphaproteobacteria (average $24 \%$ ), Actinobacteria (average 17\%), Bacilli (average 2\%) and Bacteroidia (average $0.3 \%$ ) were also observed at all

Table 2. Relative abundance (\%) of the detected species and phyla.

\begin{tabular}{|c|c|c|c|}
\hline \multirow[b]{2}{*}{ Phyla and Species } & \multicolumn{3}{|c|}{ Sampling Depth, m } \\
\hline & -80 & -120 & -300 \\
\hline Firmicutes (phylum) & 0.552 & 0.848 & $5.550^{a}$ \\
\hline Bacteroidetes (phylum) & 0.005 & 0.006 & 0.918 \\
\hline Actinobacteria (phylum) & 0.807 & $10.264^{\mathrm{a}}$ & $39.484^{\mathrm{a}}$ \\
\hline Proteobacteria (phylum) & $98.636^{a}$ & $88.882^{\mathrm{a}}$ & $54.048^{\mathrm{a}}$ \\
\hline Alphaproteobacteria (class) & $6.513^{a}$ & $16.552^{\mathrm{a}}$ & $49.186^{a}$ \\
\hline Gammaproteobacteria (class) & $92.124^{\mathrm{a}}$ & $72.255^{a}$ & $4.861^{a}$ \\
\hline Betaproteobacteria (class) & 0.000 & 0.075 & 0.000 \\
\hline Methylobacterium tardum & $6.505^{a}$ & $16.511^{a}$ & $49.179^{a}$ \\
\hline Propionibacterium acnes & 0.743 & $10.225^{a}$ & $38.144^{a}$ \\
\hline Acinetobacter Iwoffii & $91.621^{\mathrm{a}}$ & $72.238^{a}$ & $4.852^{a}$ \\
\hline Bacillus thermoamylovorans & 0.039 & 0.036 & $4.212^{\mathrm{a}}$ \\
\hline Streptococcus sanguinis & 0.508 & 0.002 & $1.125^{a}$ \\
\hline Porphyromonas spp. & 0.005 & 0.006 & 0.918 \\
\hline Rothia mucilaginosa & 0.015 & 0.015 & 0.908 \\
\hline Rhodococcus spp. & 0.002 & 0.024 & 0.271 \\
\hline Aeribacillus geobacillus pallidus & 0.000 & 0.002 & 0.203 \\
\hline Micrococcus luteus & 0.000 & 0.000 & 0.159 \\
\hline Acinetobacter johnsonii & 0.503 & 0.017 & 0.009 \\
\hline Bacillus spp. & 0.000 & 0.000 & 0.007 \\
\hline Methylobacterium fujisawaense & 0.002 & 0.015 & 0.005 \\
\hline Staphylococcus pasteuri & 0.005 & 0.807 & 0.002 \\
\hline Sulfitobacter sp. & 0.000 & 0.024 & 0.002 \\
\hline Solirubrobacter spp. & 0.047 & 0.000 & 0.002 \\
\hline Simonsiella muelleri & 0.000 & 0.075 & 0.000 \\
\hline Methylobacterium radiotolerans & 0.005 & 0.002 & 0.000 \\
\hline
\end{tabular}

a Taxonomic group with an abundance higher than $1 \%$. the depths, except for $-80 \mathrm{~m}$ and -300 $\mathrm{m}$, where Betaproteobacteria were absent. In total, 18 species were identified at 3 different depths. Only 9 of these bacteria were found to constitute $5 \%$ or more. The frequency of Acinetobacter Iwoffii, Methylobacterium tardum, and Propionibacterium acnes were the ones with the highest presence. Other species were determined to be in lower percentages (Table 2).

\section{Discussion}

Caves are special due to their formation processes and their chemical nature, are also unique in terms of microbial diversity. When exposed to human activity, caves lose their microbial richness (Lavoie and Northup, 2005; Ikner et al., 2007; Chelius et al., 2009). For this reason, studies carried out by taking samples especially during first entry and from isolated environments aim to better understand the microbiota. For cave microbiology studies, it can be said that horizontal caves are preferred because of ease of sampling compared to vertical caves. For similar reasons, the cave microbiology studies in Turkey have focused on the horizontal caves (Gulecal-Pektas, 2016; Gulecal-Pektas and Temel, 2015; Gulecal-Pektas and Temel, 2017; Candıroğlu, 2018).

This study is the first microbiological research conducted in a vertical cave in Turkey with sampling during the first 
discovery of the cave. Anthropogenic impact is expected to be unlikely for the microorganism profile in the samples taken at the time of the initial exploration of vertical caves. These previously cited reasons made our study original and also important for its intended purpose. However, the area surrounding the Yarik Sinkhole area and entrance is cluttered with summer houses of villagers that live on the lower levels of the mountains. During periods of late April to late September, villagers migrate to these settlements and use the surroundings for pasture of their livestock of cows, sheep, and especially goats. These settlements do not have infrasturcture for toiletry and waste water. All of the liquid waste goes into opened pits and from there seeps to the underground. They use the entrance of Yarik Sinkhole as garbage disposal which we had to intervene, warning them to stop throwing rubbish that includes baby diapers to rubber cycle tires, etc. There are several siphons connected to the sink from such areas that suggest anthropogenic impacts on the Yarık Sinkhole. Our study aimed to evaluate the bacterial diversity of the Yarik Sinkhole and to show possible anthropogenic impacts on diversity.

The Yarık Sinkhole resembles most cave systems with its high level of humidity and stable air temperature (Riquelme et al., 2015; Lavoie et al., 2017; Leuko et al., 2017). Similar to our findings, Leuko et al., (2017) reported a higher Ca ${ }^{2+}$ concentration than that of $\mathrm{Mg}^{+}$as a result of the chemical analysis of the water samples from the Su Betu limestone cave in Sardinia, Italy, and detected $\mathrm{HCO}_{3}{ }^{-}$as the predominant anion. Reasearchers conclued that the predominancy of $\mathrm{HCO}_{3}{ }^{-}$found in a cave indicates a calcium-bicarbonate type cave. On the other hand, the high level of $\mathrm{SO}_{4}{ }^{2-}$ detected in the water sample from the Yarık Sinkhole may indicate an oxidation of the sulphur minerals contained in the rocks in contact with the water. $\mathrm{pH}$, presence of nutrients, light, oxygen, sulphur, and compounds of other metals all affect the growth and structure of microbial communities in a humid cave. A change in those conditions can cause the differences in the composition of species (Engel et al., 2010; Jones and Bennett, 2014).

In the curent study, the phyla and their percentages present at $-80 \mathrm{~m},-120 \mathrm{~m}$ and $-300 \mathrm{~m}$ depths of Yarık Sinkhole were determined with next generation sequencing (NGS). We detected Proteobacteria, Actinobacteria, Firmicutes, and Bacteroidetes phyla. The most predominant two phyla have been found to be Proteobacteria (average $80 \%$ ) and Actinobacteria (average 16\%). The dominant groups in caves vary by the characteristics of caves (Lee et al., 2012). The major phyla found as a result of metagenomic analysis of soil samples taken from 5 caves in the Ozark Cave system are Proteobacteria (27.7\%), Acidobacteria (17.3\%), Actinobacteria (12.2\%), Firmicutes (8.2\%), Chloroflexi (8.1\%), Bacteroidetes (8\%), and Nitrospirae (6\%) (Oliveira et al., 2017). In another study, the most dominant phyla determined as a result of metagenomic analysis of sediment samples of 3 caves in Mizoram (India) were Actinobacteria (35.9\%), Chloroflexi (13.9\%), Planctomycetes (13.7\%), Acidobacteria (11.44\%), and Proteobacteria (6.6\%) (De Mandal et al., 2014). Members of the Proteobacteria and Actinobacteria phyla, dominant in both our study and many other studies, are well-adapted to growth with limited nutrients (Jurado et al., 2010; Lee et al., 2012; Barton, 2015; Wiseschart et al., 2018).

Despite the undeniable dominance of Proteobacteria in cave ecosystems, the representation of the Proteobacteria classes varies in different environments. At the class level, Gammaproteobacteria was present at all the depths, as were Alphaproteobacteria, Actinobacteria, Bacilli and Bacteroidia. Betaproteobacteria was detected only at $-120 \mathrm{~m}$ depth. Proteobacteria is a cosmopolitan bacterial group that is common and abundant (Laiz et al.,1999; Zhaou et al., 2007). Members of the Proteobacteria phylum have the abilities of utilizing different organic compounds, the fixation of atmospheric carbon, and nitrogen transformation (Tomczyk-Zak and Zielenkiewicz, 2016). It is also suggested that dominance of Proteobacteria is a result of the increasing organic input caused by cave visitors (Ikner et al., 2007). In the current study among the Proteobacteria, $92 \%, 72 \%$, and $5 \%$ were recognized in the class of Gammaproteobacteria, $6.5 \%, 16.5 \%$ and $49 \%$ as Alphaproteobacteria at $-80 \mathrm{~m},-120 \mathrm{~m}$ and $-300 \mathrm{~m}$ depths respectively. Similarly, it was determined that there were plenty of Gammaproteobacteria in soil samples taken from the Mangoo-Pee cave. $23 \%$ of the Proteobacteria found by $43 \%$ in soil sample of the Blowing Spring Cave was determined as Gammaproteobacteria, $19 \%$ as Alphaproteobacteria, and $1 \%$ as Betaproteobacteria (Barron et al., 2010).

Another dominant group, Actinobacteria, is known for being able to develop in environments containing limited nutrients, to degrade different humic material, and to dissolve phosphate and calcium carbonate (Ball et al., 1989; Dari et al., 1995; Laiz et al., 1999). It was reported that this phylum existed in cave walls, soil, sediment, and on speleothem surfaces, and it was suggested that it might have considerably contributed to the formation of the cave structures and the biomineralization in the cave ecosystem (Cuezva et al., 2012; Ortiz et al., 2013; Tomczyk-Zak and Zielenkiewicz, 2016).

Even though microorganism diversity differs by the method used (culture-depend or culture- independed), by the sampling area, and by the sample type (soil, cave wall, speleothem surface, etc.), the core phyla reported in previous cave studies are Proteobacteria and Actinobacteria (Groth et al., 1999; Tomczyk-Żak and Zielenkiewicz, 2016). Besides these, the presence frequency of the Firmicutes, Acidobacteria, Bacteroidetes, Chloroflexi, and Planctomycetes phyla in caves is at a considerable rate (Youssef and Elshahed, 2008; Jurado et al., 2010; Lee et al., 2012; Barton, 2015; Wiseschart et al., 2018). 
The evaluation of the NGS results of our study shows low diversity (only 18 species were identified through metagenomics) compared to other studies. The ingress of the waters contaminated by human/animal wastes into the Yarık Sinkhole can be one of the reasons. The microorganisms and organic substances that enter the cave from outside via contamination might negatively influence the cave's ecosystem leading in turn to the irreversible loss of its native biodiversity (Ikner et al., 2007; Chelius et al., 2009).

On the other hand, in the study conducted by Yasir (2018), 13 strains were identified by the culture method and a few genera, including Bacillus, Microbacterium, Pseudomonas, and Psychrobacter, were determined by the pyrosequencing analysis. However, in the pyrosequencing data Carnobacterium, Exiguobacterium, Paucisalibacillus and Fictibacillus were not detected. In addition, studies have shown that low abundance bacteria can be captured by culture methods (Lagier et al., 2012; Shade et al., 2012; Stefani et al., 2015). For this reason, the bacterial diversity of the environment should be determined more accurately by combining the culture methods with series based studies such as 16S rRNA gene analysis and metagenomics. Although there are some commonalities among the groups detected by using culture and molecular techniques, microorganism groups obtained through molecular results are richer since they also contain nonculturable groups as well. The results change in accordance with the characteristics of each cave (Engel et al., 2010; Jurado et al., 2010; Jones et al., 2012; Lee et al., 2012; Barton, 2015). However, when results are evaluated on the basis of species, variations in bacterial diversity of each cave become more obvious.

In the present study, Methylobacterium, Acinetobacter, Propionibacterium, and Bacillus were found more than other genera. It is known that these bacteria can utilize a wide variety of carbon sources and play an important role in calcification (Hiraishi et al., 1995; Cacchio et al., 2004; Portillo et al., 2008; Busquets et al., 2014). Propionibacterium acnes and Acinetobacter Iwoffii can really get an advantage in vivo from polyphosphate as an energy reserve and they may use it during periods of starvation or unfavorable conditions (Van Groenestijn et al., 1987; Chen, 1999). A. Iwoffii, $P$. acnes, and Streprococcus sanguinis that were found at $1 \%$ or higher in at least one of the sampled depths cause diseases such as bacteremia, pulmonary infections, meningitis, sepsis, pneumonia, bacterial endocarditis, and periodontal diseases (Doughari et al., 2011; Baker et al., 2018; Achermann et al., 2014). Also A. Iwoffii is a normal flora of the oropharynx and the skin in approximately $25 \%$ of healthy individuals (Regalado et al., 2009). According to research conducted by the Human Microbiome Project the bacteria of the genera Consortium Lactobacillus, Propionibacterium, Streptococcus, Bacteroides, Corynebacterium, Staphylococcus, Moraxella, Haemophilus, Prevotella, and Veillonella are of human origin (Huttenhower et al. 2012). Leuko et al., (2017) detected a high level of $P$. acnes in their study conducted in the Su Bentu limestone cave in Sardinia, Italy, and associated that result with human contamination. To our knowledge, all of the bacteria that were found in the samples collected from Yarık Sinkhole were previously found in caves, except for Sulfitobacter (Busquets et al., 2014; De Mandal et al., 2014; Herzog Velikonja et al., 2014; Kieraite-Aleksandrova et al., 2015; Riquelme et al., 2015; Leuko et al., 2017).

The achievement of sampling in parallel to the discovery of the Yarık Sinkhole separates this study from other cave microbiology studies to a significant extent. Analysis of the samples showed that the bacterial diversity is limited and the detected bacteria are generally originated from humans. These results show that anthropogenic activities around a vertical cave such as the Yarık Sinkhole cause contamination of the cave.

\section{Acknowledgements}

This work was supported by thelstanbul University Scientific Project Unit (BAP Project No: FBA-2017-24145). The Anatolian Speleology Association are acknowledged for their assistance in sampling.

\section{References}

Achermann, Y., Goldstein, E.J., Coenye, T., and Shirtliff M.E., 2014, Propionibacterium acnes: from commensal to opportunistic biofilm-associated implant pathogen: Clinical Microbiology Reviews, v. 27, no. 3, p. 419-440. https://doi.org/ 10.1128/CMR.00092-13.

APHA, 1992, Standard Methods for Examination Water and Wastewater, 17th ed. Am. Publ. Hlth Assoc.,Washington, D.C.

Baker, S.P., Nulton, T.J., and Kitten, T., 2018, Genomic, phenotypic, and virulence analysis of Streptococcus sanguinis oral and infective endocarditis isolates: Infection and Immunity, v. 87, no. 1, p. 1-18. https://doi.org/ 10.1128/IAI.00703-18.

Ball, A.S., Betts, W.B., and Mccarthy, A.J., 1989, Degradation of lignin-related compounds by actinomycetes: Applied and Environmental Microbiology, v. 55, p. 1642-1644.

Barron, S.K., Murdock, C.A., Blair, B.G., Meade, M.E., and Barger, T.W., 2010, Analysis of bacterial diversity in soils from Blowing Spring Cave (Lauderdale County, AL): The Journal of the Alabama Academy of Science, v. 81, p. 1-10.

Barton, H.A., 2015, Starving artists: Bacterial oligotrophic heterotrophy in caves: in Life in Extreme Environments: Microbial Life of Cave Systems, Ed. A. Engel, Walter DeGruyter, Berlin, Germany, p. 79-95.

Barton, H.A., Taylor, N.M., Kreate, M.P., Springer, A.C., Oehrle, S.A., and Bertog, J.L., 2007, The impact of host rock geochemistry on bacterial community structure in oligotrophic cave environments: International Journal of Speleology, v. 36, p. 93-104. http://dx.doi.org/10.5038/1827-806X.36.2.5.

Busquets, A., Fornós, J.J., Zafra, F., Lalucat, J., and Merino, A., 2014, Microbial communities in a coastal cave: Cova des Pas de Vallgornera (Mallorca, Western Mediterranean): International Journal of Speleology, v. 43, p, 205-216. https://doi.org/ 10.5038/1827-806X.43.2.8. 
Cacchio, P., Contento, R., Ercole, C., Cappuccio, G., Martinez, M.P., and Lepidi, A., 2004, Involvement of microorganisms in the formation of carbonate speleothems in the Cervo Cave (L'Aquila-Italy): Geomicrobiology Journal, v. 21, no. 8, p. 497-509. https://doi. org/10.1080/01490450490888109.

Candiroglu, B., 2018, Antimicrobial component productivity and antibiotic resistance of bacteria isolated from a cave [M.S. thesis]: Istanbul, Istanbul University. https://tez.yok.gov.tr/UlusalTezMerkezi/tezSorguSonucYeni.jsp

Chelius, M.K., Beresford, G., Horton, H., Quirk, M., Selby, G., Simpson, R.T., Horrocks, R., and Moore, J.C., 2009, Impacts of alterations of organic inputs on the bacterial community within the sediments of Wind Cave, South Dakota, USA: International Journal of Speleology, v. 38, p. 1-10. http://dx.doi.org/10.5038/1827-806X.38.1.1.

Chen, K.Y., 1999, Study of polyphosphate metabolism in intact cells by 31-P nuclear magnetic resonance spectroscopy. in Inorganic Polyphosphates, Ed. Schröder, H.C., Müller, W.E.G, Springer, Berlin, Heidelberg. p. 253-273. https://doi.org/10.1007/978-3-642-58444-2_13.

Cuezva, S., Fernandez-Cortes, A., Porca, E., Pašić, L., Jurado, V., Hernandez-Marine, M., Serrano-Ortiz, P., Hermosin, B., Cañaveras, J.C., Sanchez-Moral, S., and Saiz-Jimenez C., 2012, The biogeochemical role of actinobacteria in Altamira cave, Spain: FEMS Microbiology Ecology, v.81, no.1, p. 281-290. https://doi.org/10.1111/j.1574-6941.2012.01391.x.

Dari, K., Bechet, M., and Blondeau, R., 1995, Isolation of soil Streptomyces strains capable of degrading humic acids and analysis of their peroxidase-activity: FEMS Microbiology Ecology, v. 16, p. 115-121. https://doi.org/10.1016/0168-6496(94)00075-8.

De Mandal, S., Sanga, Z., and Nachimuthu, S.K., 2014, Metagenomic analysis of bacterial community composition among the cave sediments of Indo-Burman biodiversity hot spotregion: PeerJ Preprints, 2: e631v1. https://doi.org/10.7287/peerj.preprints.631v1.

Donachie, S.P., Foster, J. S., and Brown, M.V., 2007, Culture clash: challenging the dogma of microbial diversity: The ISME Journal, v.1, no.2, p. 97-99. https://doi.org/10.1038/ismej.2007.22

Doughari, H.J., Ndakidemi, P.A., Human, I.S., and Benade S., 2011, The ecology, biology and pathogenesis of Acinetobacter spp.: an overview: Microbes and Environments, v. 26, no. 2, p. 101-112. https://doi.org/10.1264/jsme2.me10179.

Edgar, R.C., Haas, B.J., Clemente, J.C., Quince, C., and Knight, R., 2011, UCHIME improves sensitivity and speed of chimera detection: Bioinformatics, v. 27, no. 16, p. 2194-2200. https://doi.org/10.1093/bioinformatics/btr381.

Engel, A.S., Meisinger, D.B., Porter, M.L., Payn, R.A., Schmid, M., Stern, L.A., Schleifer, K.H., and Lee N.M., 2010, Linking phylogenetic and functional diversity to nutrient spiraling in microbial mats from Lower Kane Cave (USA): The ISME journal, v. 4, no. 1, p. 98-110. https://doi. org/ 10.1038/ismej.2009.91.

General Directorate of Mineral Research and Exploration. http://www.mta.gov.tr/ v3.0/ arastirmalar/ magara-envanteri [accessed: July 28, 2017].

Groth, I., Vettermann, R., Schuetze, B., Schumann, P., and Saiz-Jiménez, C., 1999, Actinomycetes in karstic caves of Northern Spain (Altamira and Tito Bustillo): Journal of Microbiological Methods, v. 36, p. 115-122.

Gulecal-Pektas, Y., 2016, Bacterial diversity and composition in Oylat Cave (Turkey) with combined sanger/pyrosequencing approach: Polish Journal of Microbiology, v. 65, no. 1, p. 69-75. https://doi.org/ 10.5604/17331331.1197277.

Gulecal-Pektas, Y., and Temel, M., 2015, Determination of microbial diversity in moonmilk deposits with next generation sequencing: Fresenius Environmental Bulletin, v. 24, no. 3, p. 825-832.

Gulecal-Pektas, Y., and Temel, M., 2017, A window to the subsurface: microbial diversity in hot Ssprings of a sulfidic cave (Kaklik, Turkey): Geomicrobiology Journal, v. 34, no. 4, p. 374-384. https://doi.org/10.1080/01490451.2016.1204374.

Herzog Velikonja, B., Tkavc, R., and Pašić, L., 2014, Diversity of cultivable bacteria involved in the formation of macroscopic microbial colonies (cave silver) on the walls of a cave in Slovenia: International Journal of Speleology, v. 43, p. 45-56. https://doi.org/10.5038/1827-806x.43.1.5.

Hiraishi, A., Furuhata, K., Matsumoto, A., Koike, K.A., Fukuyama, M., and Tabuchi, K., 1995, Phenotypic and genetic diversity of chlorine resistant Methylobacterium strains isolated from various environments: Applied and Environmental Microbiology, v. 61, p. $2099-2107$.

Huttenhower, C., Gevers, D., Knight, R., Abubucker, S., Badger, J.H., Chinwalla, A.T., Creasy, H.H., Earl, A.M., FitzGerald, M.G., Fulton, R.S., Giglio, M.G., Hallsworth-Pepin, K., Lobos, E.A., Madupu, R., Magrini, V., Martin, J.C., Mitreva, M., Muzny, D.M., Sodergren, E.J., Versalovic, J., Wollam, A.M., Worley, K.C., Wortman, J.R., Young, S.K., Zeng, Q., Aagaard, K.M., Abolude, O.O., Allen-Vercoe, E., Alm, E.J., Alvarado, L., Andersen, G.L., Anderson, S., Appelbaum, E., Arachchi, H.M., Armitage, G., Arze, C.A., Ayvaz, T., Baker, C.C., Begg, L., Belachew, T., Bhonagiri, V., Bihan, M., Blaser, M.J., Bloom, T., Bonazzi, V., Brooks, J.P., Buck, G.A., Buhay, C.J., Busam, D.A., Campbell, J.L., Canon, S.R., Cantarel, B.L., Chain, P.S.G., Chen, I.A., Chen, L., Chhibba, S., Chu, K., Ciulla, D.M., Clemente, J.C., Clifton, S.W., Conlan, S., Crabtree, J., Cutting, M.A., Davidovics, N.J., Davis, C.C., DeSantis, T.Z., Deal, C., Delehaunty, K.D., Dewhirst, F.E., Deych, E., Ding, Y., Dooling, D.J., Dugan, S.P., Dunne, W.M., Durkin, A.S., Edgar, R.C., Erlich, R.L., Farmer, C.N., Farrell, R.M., Faust, K., Feldgarden, M., Felix, V.M., Fisher, S., Fodor, A.A., Forney, L.J., Foster, L., Francesco, V.D., Friedman, J., Friedrich, D.C., Fronick, C.C., Fulton, L.L., Gao, H., Garcia, N., Giannoukos, G., Giblin, C., Giovanni, M.Y., Goldberg, J.M., Goll, J., Gonzalez, A., Griggs, A., Gujja, S., Haake, S.K., Haas, B.J., Hamilton, H.A., Harris, E.L., Hepburn, T.A., Herter, B., Hoffmann, D.E., Holder, M.E., Howarth, C., Huang, K.H., Huse, S.M., Izard, J., Jansson, J.K., Jiang, H., Jordan, C., Joshi, V., Katancik, J.A., Keitel, W.A., Kelley, S.T., Kells, C., King, N.B., Knights, D., Kong, H.H., Koren, O., Koren, S., Kota, K.C., Kovar, C.L., Kyrpides, N.C., La Rosa, P.S., Lee, S.L., Lemon, K.P., Lennon, N., Lewis, C.M., Lewis, L., Ley, R.E., Li, K., Liolios, K., Liu, B., Liu, Y., Lo, C.C., Lozupone, C.A., Lunsford, R.D., Madden, T., Mahurkar, A.A., Mannon, P.J., Mardis, E.R., Markowitz, V.M., Mavromatis, K., McCorrison, J.M., McDonald, D., McEwen, J., McGuire, A.L., McInnes, P., Mehta, T., Mihindukulasuriya, K.A., Miller, J.R., Minx, P.J., Newsham, I., Nusbaum, C., O'Laughlin, M., Orvis, J., Pagani, I., Palaniappan, K., Patel, S.M., Pearson, M., Peterson, J., Podar, M., Pohl, C., Pollard, K.S., Pop, M., Priest, M.E., Proctor, L.M., Qin, X., Raes, J., Ravel, J., Reid, J.G., Rho, M., Rhodes, R., Riehle, K.P., Rivera, M.C., Rodriguez-Mueller, B., Rogers, Y.H., Ross, M.C., Russ, C., Sanka, R.K., Sankar, P., Sathirapongsasuti, J.F., Schloss, J.A., Schloss, P.D., Schmidt, T.M., Scholz, M., Schriml, L., Schubert, A.M., Segata, N., Segre, J.A., Shannon, W.D., Sharp, R.R., Sharpton, T.J., Shenoy, N.,. Sheth, N.U., Simone, G.A., Singh, I., Smillie, C.S., Sobel, J.D., Sommer, D.D., Spicer, P., Sutton, G.G., Sykes, S.M., Tabbaa, D.G., Thiagarajan, M., Tomlinson, C.M., Torralba, M., Treangen, T.J., Truty, R.M., Vishnivetskaya, T.A., Walker, J., Wang, L., Wang, Z., Ward, D.V., Warren, W., Watson, M.A., Wellington, C., Wetterstrand, K.A., White, J.R., Wilczek-Boney, K., Wu, Y., Wylie, K.M., Wylie, T., Yandava, C., Ye, L., Ye, Y., Yooseph, S., Youmans, B.P., Zhang, L., Zhou, Y., Zhu, Y., Zoloth, L., Zucker, J.D., Birren, B.W., Gibbs, R.A., Highlander, S.K., Methé, B.A., Nelson, K.E., Petrosino, J.F., Weinstock, G.M., Richard K. Wilson,R.K. and White, O., 2012, Structure, function and diversity of the healthy human microbiome: Nature, v. 486, no.7402, p. 207-214. https://doi.org/10.1038/nature11234.

Ikner, L.A., Toomey, R.S., Nolan, G., Neilson, J.W., Pryor, B.M., and Maier, R.M., 2007, Culturable microbial diversity and the impact of tourism in Kartchner Caverns, Arizona: Microbial Ecology, v. 53, p. 30-42. https://doi.org/ 10.1007/s00248-006-9135-8.

Jones, A.A., and Bennett, P.C., 2014, Mineral microniches control the diversity of subsurface microbial populations: Geomicrobiology Journal, v. 31, no. 3, p. 246-261. https://doi.org/10.1080/01490451.2013.809174.

Jones, D.S., Albrecht, H.L., Dawson, K.S., Schaperdoth, I., Freeman, K.H., Pi Y., Pearson, A., and Macalady, J.L., 2012, Community genomic analysis of an extremely acidophilic sulfur-oxidizing biofilm: The ISME Journal, v. 6, p. 158-170. https://doi.org/ 10.1038/ismej.2011.75.

Jurado, V., Laiz, L., Rodriguez-Nava, V., Boiron, P., Hermosin, H., Sanchez-Moral S., and Saiz-Jimenez, C., 2010, Pathogenic and opportunistic microorganisms in caves: International Journal of Speleology, v.39, p. 15-24. https://doi.org/ 10.5038/1827-806X.39.1.2. 
Kieraite-Aleksandrova, I., Aleksandrovas, V., and Kuisiene, N., 2015, Down into the Earth: microbial diversity of the deepest cave of the world: Biologia, v. 70, no. 8, p. 989-1002. https://doi.org/ 10.1515/biolog-2015-0127.

Klindworth, A., Pruesse, E., Schweer, T., Peplles, J., Quast, C., Horn, M., and Glöckner, F.O., 2013, Evaluation of general 16S ribosomal RNA gene PCR primers for classical and next-generation sequencing-based diversity studies: Nucleic Acids Research, v. 41, no. 1, p. 1-11. https:// doi.org/10.1093/nar/gks808.

Laiz, L., Groth, I., Gonzalez, I., and Saiz-Jimenez, C., 1999, Microbiological study of the dripping waters in Altamira Cave (Santillana del Mar, Spain): Journal of Microbiological Methods, v. 36, p. 129-138.

Lagier, J.C., Armougom, F., Million, M., Hugon, P., Pagnier, I., Robert, C., Bittar, F., Fournous, G., Gimenez, G., Maraninchi, M., Trape, J.F., Koonin, E.V., La Scola, B., and Raoult, D., 2012, Microbial culturomics: paradigm shift in the human gut microbiome study: Clinical Microbiology and Infection, v. 18, no. 12, p.1185-1193. https://doi.org/10.1111/1469-0691.12023.

Lavoie, K.H., Winter, A.S., Read, K.J., Hughes, E.M., Spilde, M.N., and Northup, D.E., 2017, Comparison of bacterial communities from lava cave microbial mats to overlying surface soils from Lava Beds National Monument, USA: PloS One, v. 12, no. 12, e0169339. doi:10.1371/journal.pone.0169339

Lee, I.T., Liu, J.Y., Lin, C.H., Oyama, K.I., Chen, C.Y., and Chen, C.H., 2012, Ionospheric plasma caves under the equatorial ionization anomaly: Journal of Geophysical Research, v. 117, no. A11309, p. 1-9. https://doi.org/10.1029/2012JA017868.

Leuko, S., Koskinen, K., Sanna, L., D’Angeli, I.M., De Waele, J., Marcia, P., Moissl-Eichinger, C., and Rettberg, P., 2017, The influence of human exploration on the microbial community structure and ammonia oxidizing potential of the Su Bentu limestone cave in Sardinia, Italy: PLoS One, v. 12, no. 7, p. 1-22. https://doi.org/10.1371/journal.pone.0180700.

Nelson, M.C., Morrison, H.G., Benjamino, J., Grim, S.L., and Graf, J., 2014, Analysis, optimization and verification of illumina-generated 16S rRNA gene amplicon surveys: PLoS One, v. 9, no. 4-e94249, p. 1-14. https://doi.org/10.1371/journal.pone.0094249.

Northup, D.E., and Lavoie, K.H., 2001, Geomicrobiology of caves: a review: Geomicrobiology Journal, v. 18, p. 199-222. https://doi. org/10.1080/01490450152467750.

Oliveira, C., Gunderman, L., Coles, C.A., Lochmann, J., Parks, M., Ballard, E., Glazko, G., Rahmatallah, Y., Tackett, A.J., and Thomas, D.J., 2017, 16 S rRNA gene-based metagenomic analysis of Ozark Cave bacteria: diversity, v. 9, no. 3, p. 1-16. https://doi.org/10.3390/d9030031.

Ortiz, M., Legatzki, A., Neilson, J.W., Fryslie, B., Nelson, W.M., Wing, R.A., Soderlund, C.A., Pryor, B.M., and Maier, R.M., 2014, Making a living while starving in the dark: metagenomic insights into the energy dynamics of a carbonate cave: The ISME Journal, v. 8, no. 2, p. 478-491. https://doi.org/10.1038/ismej.2013.159.

Palmer, A.N., 1991, Origin and morphology of limestone caves: Geological Society of America Bulletin, v. 103, p. 1-21. https://doi.org/10.1130/00 16-7606(1991)103<0001:OAMOLC>2.3.CO;2

Portillo, M.C., Gonzalez, J.M., and Saiz-Jimenez, C., 2008, Metabolicallyactive microbial communities of yellow and grey colonizations on the walls of Altamira Cave, Spain: Journal of Applied Microbiology, v. 104, p. 681-691. https://doi.org/ 10.1111/j.1365-2672.2007.03594.x.

Pruesse, E., Quast, C., Knittel, K., Fuchs, B.M., Ludwig, W., Peplies, J., and Glöckner, F.O., 2007, SILVA: a comprehensive online resource for quality checked and aligned ribosomal RNA sequence data compatible with ARB: Nucleic Acids Research, v. 35, no. 21, p. 7188-7196. https:// doi.org/10.1093/nar/gkm864.

Regalado, N.G., Martin, G., and Antony, S.J., 2009, Acinetobacter /woffii: bacteremia associated with acute gastroenteritis: Travel Medicine and Infectious Disease, v. 7, no. 5, p. 316-317. https://doi.org/10.1016/j.tmaid.2009.06.001.

Riquelme, C., Marshall Hathaway, J.J., Enes Dapkevicius, M.L.N., Miller, A.Z., Kooser, A., Northup, D.E., Jurado, V., Fernandez, O., Saiz-Jimenez, C., and Cheeptham N., 2015, Actinobacterial diversity in volcanic caves and associated geomicrobiological interactions: Frontiers in Microbiology, v. 6, no. 1342, p. 1-16. https://doi.org/ 10.3389/fmicb.2015.01342.

Shabarova, T., Widmer, F., and Pernthaler, J., 2013, Mass effects meet species sorting: transformations of microbial assemblages in epiphreatic subsurface karst water pools: Environmental Microbiology, v. 15, no. 9, p. 2476-2488. https://doi.org/10.1111/1462-2920.12124.

Shade, A., Hogan, C.S., Klimowicz, A.K., Linske, M., McManus, P.S., and Handelsman, J., 2012, Culturing captures members of the soil rare biosphere: Environmental Microbiology, v. 14, no. 9, p. 2247-2252. https://doi.org/ 10.1111/j.1462-2920.2012.02817.x

Stefani, F.O., Bell, T.H., Marchand, C., Ivan, E., El Yassimi, A., St-Arnaud, M., and Hijri, M., 2015, Culture-dependent and-independent methods capture different microbial community fractions in hydrocarbon-contaminated soils: PLoS One, v. 10, no. 6-e0128272, p. 1-16. https://doi. org/10.1371/journal.pone.0128272.

Tomczyk-Żak, K., and Zielenkiewicz, U., 2016, Microbial diversity in caves: Geomicrobiology Journal, v. 33, p. 20-38. https://doi.org/10.1080/014 90451.2014.1003341.

Torsvik, V., and Øvreås, L., 2002, Microbial diversity and function in soil: from genes to ecosystems: Current Opinion in Microbiology, v. 5, no. 3, p. 240-245.

TSE., 1996 TS 9748 EN 27888: Water quality—determination of electrical conductivity: Turkish Standard Institution, Ankara

TSE., 1999, TS 3263 ISO 10523: Water quality—determination of pH: Turkish Standard Institution, Ankara

Ulu, Ü., 1983, Sugözü-Gazipaşa (Antalya) Alanının Jeoloji İncelemesi: Jeoloji Mühendisliği Dergisi, v. 7, no. 1, p. 3-10.

Van Groenestijn, J.W., Deinema, M.H., and Zehnder, A.J., 1987, ATP production from polyphosphate in Acinetobacter strain 210A: Archives of Microbiology, v. 148, no. 1, p. 14-19. https://doi.org/10.1007/bf00429640.

Wiseschart, A., Mhuanthong, W., Thongkam, P., Tangphatsornruang, S., Chantasingh, D., and Pootanakit, K., 2018, Bacterial diversity and phylogenetic analysis of type II polyketide synthase gene from Manao-Pee Cave, Thailand: Geomicrobiology Journal, v. 35, no. 6, p. 518-527. https://doi.org/10.1080/01490451.2017.1411993.

Yasir, M., 2018, Analysis of bacterial communities and characterization of antimicrobial strains from cave microbiota: Brazilian Journal of Microbiology, v. 49, no. 2, p. 248-257. https://doi.org/10.1016/j.bjm.2017.08.005.

Youssef, N.H., and Elshahed, M.S., 2008, Diversity rankings among bacterial lineages in soil: The ISME Journal, v. 3, p. 305-313. https://doi. org/10.1038/ismej.2008.106.

Zhou, J., Gu, Y., Zou, C., and Mo, M., 2007, Phylogenetic diversity of bacteria in an earth-cave in Guizhou Province, Southwest of China: Journal of Microbiology, v. 45, p. 105-112. 
Kirk S. Zigler, Matthew L. Niemiller, Charles D.R. Stephen, Breanne N. Ayala, Marc A. Milne, Nicholas S. Gladstone, Annette S. Engel, John B. Jensen, Carlos D. Camp, James C. Ozier, and Alan Cressler. Biodiversity from caves and other subterranean habitats of Georgia, USA. Journal of Cave and Karst Studies, v. 82, no. 2, p. 125-167. DOI:10.4311/2019LSC0125

\section{BIODIVERSITY FROM CAVES AND OTHER SUBTERRANEAN HABITATS OF GEORGIA, USA}

Kirk S. Zigler ${ }^{1 C}$, Matthew L. Niemiller ${ }^{2}$, Charles D.R. Stephen ${ }^{3}$, Breanne N. Ayala1, Marc A. Milne ${ }^{4}$, Nicholas S. Gladstone ${ }^{5}$, Annette S. Engel ${ }^{6}$, John B. Jensen ${ }^{7}$, Carlos D. Camp ${ }^{8}$, James C. Ozier ${ }^{9}$, and Alan Cressler $^{10}$

\section{Abstract}

We provide an annotated checklist of species recorded from caves and other subterranean habitats in the state of Georgia, USA. We report 281 species (228 invertebrates and 53 vertebrates), including 51 troglobionts (cave-obligate species), from more than 150 sites (caves, springs, and wells). Endemism is high; of the troglobionts, 17 (33\% of those known from the state) are endemic to Georgia and seven (14\%) are known from a single cave. We identified three biogeographic clusters of troglobionts. Two clusters are located in the northwestern part of the state, west of Lookout Mountain in Lookout Valley and east of Lookout Mountain in the Valley and Ridge. In addition, there is a group of troglobionts found only in the southwestern corner of the state and associated with the Upper Floridan Aquifer. At least two dozen potentially undescribed species have been collected from caves; clarifying the taxonomic status of these organisms would improve our understanding of cave biodiversity in the state. Conservation concerns related to species found in Georgia caves are significant, with fourteen species (including 13 vertebrates) considered "High Priority Species" under the Georgia State Wildlife Action Plan, many of these species have additional state or federal protections. In addition, 17 invertebrate troglobionts (33 \% of those known in the state) are considered "Critically Imperiled" by NatureServe. Several biologically important caves are not protected, these are an important conservation concern. However, remarkably, around one third of all caves in the state are on protected lands, including seven of the eight caves known to host ten or more troglobionts.

\section{Introduction}

Caves and karst in Georgia are limited to two geologically distinct and disconnected regions in the northwestern and the southwestern corners of the state (Culver et al., 2003; Hobbs, 2012). In northwestern Georgia, caves occur in the Appalachian Valley and Ridge physiographic province and along the escarpments of Sand Mountain and Lookout Mountain of the Cumberland Plateau. Caves in the northwest formed in carbonate sedimentary rock units that date to the Paleozoic era (i.e., Cambrian to Mississippian periods, from 400 to 350 million years old). These units have been folded and faulted during mountain building episodes associated with the southern Appalachian Mountains. In Georgia, Lookout Mountain divides the caves of Appalachian Valley and Ridge into two distinct groups - those west of Lookout Mountain in Lookout Valley, and those east of Lookout Mountain. In southwestern Georgia, caves are known from the Dougherty Plain, also known as the Lime Sink region of the Coastal Plain province, in Eocene- to Oligocene-aged (about 25 million years old) carbonate rocks that lie above the underlying Upper Floridan Aquifer. In total, 670 caves have been documented in Georgia (Georgia Speleological Survey, 2018). Twenty-six caves are more than $1 \mathrm{~km}$ in length, and four caves are more than $5 \mathrm{~km}$ long (Georgia Speleological Survey, 2018). The highest cave density occurs in the northwestern part of the state, with 247 and 186 caves known from Walker and Dade counties, respectively. No other county has more than 40 documented caves (Georgia Speleological Survey, 2018).

The first review of subterranean biodiversity in Georgia reported 130 species of invertebrates from 29 caves (Holsinger and Peck, 1971). Twenty-seven of those caves were in northwestern Georgia, and two caves were in the Gulf Coastal Plain. Franz et al. (1994) reviewed cave biodiversity in Florida, including records for a handful of sites in southwestern Georgia. A second major review of cave biodiversity in Georgia (Reeves et al., 2000) identified 173 invertebrate taxa from 47 caves. As more caves have been biologically investigated, the number of troglobionts (cave-obligate species) known from Georgia has increased from 24 to 27 (Holsinger and Peck, 1971) to 50 (Niemiller et al., 2019).

\footnotetext{
1Department of Biology, University of the South, Sewanee, TN 37383

${ }^{2}$ Department of Biological Sciences, The University of Alabama in Huntsville, Huntsville, AL 35899

${ }^{3}$ Department of Biological Sciences, Auburn University, Auburn, AL 36849

${ }^{4}$ Department of Biology, University of Indianapolis, Indianapolis, IN 46227

${ }^{5}$ School of Fisheries, Aquaculture and Aquatic Sciences, Auburn University, Auburn, AL 36849

${ }^{6}$ Department of Earth and Planetary Sciences, University of Tennessee, Knoxville, TN 37996

${ }^{7}$ Georgia Department of Natural Resources, Wildlife Conservation Section, Forsyth, GA 31029

${ }^{8}$ Department of Biology, Piedmont College, Demorest, GA 30535

${ }^{9}$ Environmental and Natural Resources, Georgia Power Company, Atlanta, GA 30308

${ }^{10}$ Independent Researcher, Atlanta, GA

cCorresponding author: kzigler@sewanee.edu
} 
Since the Reeves et al. (2000) review, numerous studies have added to our knowledge of subterranean biodiversity in Georgia. Biological surveys of Georgia caves have continued (Buhlmann et al., 2001; Reeves and McCreadie, 2001; Campbell et al., 2011, 2012; Jensen and Ozier, unpublished). Phylogeographic studies and taxonomic revisions have included taxa from Georgia caves (e.g., Niemiller et al., 2008, 2011; Shear, 2010; Ledford et al., 2011; Leray et al., 2019). Additional studies have reported behavioral information for species found in caves (Camp and Jensen, 2007; Disney and Campbell, 2011; Carver et al., 2016), and others have improved our understanding of the distribution of specific troglobionts in Georgia, such as the Southern Cavefish (Typhlichthys subterraneus; Niemiller et al., 2016) and the Dougherty Plain Cave Crayfish (Cambarus cryptodytes; Fenolio et al., 2017). This wealth of new information, as well as the results of our work in caves and wells in Georgia, encouraged us to review biodiversity of caves and other subterranean habitats across the state.

\section{Methods}

We conducted faunal bioinventories of caves and wells in nine counties of Georgia on more than 350 visits between 2000 and 2019. Many of these caves had never been bioinventoried. Bioinventories primarily consisted of visual encounter surveys for cave life in terrestrial, riparian, and aquatic habitats. Searched areas of caves included entrance areas starting at the drip line, accessible walls and ceilings, ledges, mud banks, rimstone pools, streams, and talus slopes. These surveys systematically traversed the cave, from the entrance to the farthest extent of the cave explorable by the research team. Search effort included examining and overturning rocks, detritus, organic debris, and other cover, as well as searching through stream cobble. At some sites we supplemented visual encounter surveys with baited traps and bulk samples of organic debris (including leaf litter, guano, and rodent nests) that were brought to the laboratory and placed on Berlese-Tullgren funnels to extract invertebrates.

We only field-identified common, more tractable invertebrate species. In all other cases, we collected invertebrate specimens and identified them in the laboratory using available taxonomic literature. We outsourced identification to experts for taxa with which we had insufficient taxonomic knowledge. For birds and mammals, we field-identified taxa by direct observation of individuals by sight or sound without capture or through taxonomically reliable indirect observations, such as visual identification of mammal scat or footprints left in mud. Where possible, we took voucher photographs of birds and mammals. For amphibians, fishes, and reptiles, we made a concerted effort to capture each observed individual to confirm its identification and obtain a voucher photograph with the specimen in hand. For some vertebrates, we collected tissue samples and voucher specimens. Depending on the extent of the cave system, surveys were done by two to five surveyors, with a search effort of two to 12 person-hours per cave visit.

We searched for additional records of Georgia subterranean fauna in the scientific literature, biodiversity databases, unpublished government reports, unpublished technical reports, unpublished specimen identification catalogs of taxonomists, and museum accession records. Scientific literature sources included peer-reviewed journals, books, proceedings, theses, and dissertations. We also reviewed caving organization newsletters. Biodiversity database sources we directly queried included the Georgia Department of Natural Resources biodiversity database and the Bat Population Data Project (https://my.usgs.gov/bpd/). We queried all records for Animalia from the Global Biodiversity Information Facility (GBIF, https://gbif.org), a data aggregator of specimen databases and museum collections (including VertNet, http://www.vertnet.org). Our GBIF search comprised 214,566 unique records from 272 datasets hosted in 20 countries of preserved animal specimens from a geographic polygon containing Georgia (http://www.GBIF.org, 2019). We parsed the downloaded data through iterative searches for all taxa having specimen collections from subterranean features (e.g., caves, mines, springs, and wells) (Supplementary Text S1), georeferenced each record to confirm its location within the state, and reviewed each record to confirm that it was found in a subterranean feature, as opposed to on the surface in the vicinity of a subterranean feature.

Cave data-including descriptions, locations, and maps-are maintained by the Georgia Speleological Survey (GSS; http://gss.io.caves.org/). For each cave we report the cave name and alphanumeric code ('cave number') in current use by GSS. Associating a record from the literature with a cave in the GSS database was generally straightforward, even in cases where a single cave has been referred to by more than one name in the past. In cases where we could not confidently identify the cave associated with an occurrence record, we included these data in the list of records (Supplementary Table S2) but excluded them from georeferencing. Due to the sensitivity of cave data, we refer to caves only by their cave number, cave name, and county. We recommend readers contact GSS or the corresponding author for information on particular cave systems. Locality and name data for springs in Georgia are in the public domain and maintained in a searchable database (USGS, 2019).

The annotated list includes the scientific name, authority, ecological classification, common name, and conservation status for each species. Taxonomic nomenclature primarily followed the Integrated Taxonomic Information System (https://itis.gov/), supplemented by taxon-specific sources such as the World Spider Catalog (https://wsc.nmbe.ch/), 
Bellinger et al. (1996-2019), and Harvey $(1990,2013)$. Where available we included common names. Ecological classifications of subterranean organisms (cavernicoles) have been proposed by several authors (e.g., Barr, 1968; Sket, 2008; Culver and Pipan, 2009). Following Niemiller et al. (2016), we used terminology from Barr (1968) with clarification from Sket (2008) and Culver and Pipan (2009) to indicate species found in terrestrial (troglo-) versus aquatic (stygo-) habitats. Four primary ecological categories were used: troglobiont (TB) or stygobiont (SB) (synonyms: troglobite or stygobite, respectively), troglophile (TP) or stygophile (SP) (synonym: eutroglophile), trogloxene or stygoxene (TX or SX) (synonym: subtroglophile), and accidental (AC) (synonym: trogloxene, sensu Sket, 2008). We also used two secondary ecological categories: edaphic (ED) for soil-dwelling animals not typically considered cavernicoles, and symbiont (SY) for commensals and parasites. Troglobionts and stygobionts are obligate cavernicoles that typically exhibit morphological, physiological, and behavioral adaptations for living in subterranean habitats and that have few or no records from surface habitats. Troglophiles and stygophiles frequent subterranean habitats and can complete their life cycles within caves but also may occur in surface habitats. Trogloxenes and stygoxenes use subterranean habitats seasonally, or for only a portion of their life cycles, but also rely significantly on surface habitats. Accidentals are species found in caves only by accident, such as by falling into a pit or being washed into a cave during a flood. When available, we relied on ecological categories assigned to taxa by earlier authors (e.g., Holsinger and Peck, 1971; Reeves et al., 2000; Buhlmann, 2001; Niemiller et al., 2016). With many species, these categories have necessarily been subjectively inferred by previous authors due to lacking or nonexistent natural history data, which is especially true with invertebrates. We altered categories in cases where it was justified by new ecological or morphological data.

When available, the conservation status of each species, based on the International Union for Conservation of Nature (IUCN) Red List of Threatened Species (http://www.iucnredlist.org/ [accessed January 12, 2019]) and NatureServe (http://www.natureserve.org/ [accessed January 12, 2019]), is included to provide a better understanding of the distribution and biogeography of subterranean organisms in Georgia, and to aid in the future conservation and management of this unique fauna. The status of a species according to the U.S. list of threatened and endangered species under the Endangered Species Act is included (http://www.fws.gov/endangered), as well as if a species is included on the list of rare animals in Georgia (https://georgiabiodiversity.org/natels/element_lists.html). Seven IUCN (International Union for the Conservation of Nature, 2012) Red List categories are recognized on a continuum of increasing extinction risk: Least Concern, Near Threatened, Vulnerable, Endangered, Critically Endangered, Extinct in the Wild, and Extinct. Critically Endangered, Endangered, and Vulnerable are considered Threatened categories. NatureServe conservation status ranks are based on a one to five scale, from most to least at risk of extinction (Faber-Langendoen et al., 2012 ): 1 (Critically Imperiled), 2 (Imperiled), 3 (Vulnerable), 4 (Apparently Secure), and 5 (Secure). Two additional ranks associated with extinction exist: $\mathrm{H}$ (Possibly Extinct) and $\mathrm{X}$ (Presumed Extinct). Status ranks are assessed at three geographic scales: global (G1-5), national (N1-5), and state (S1-5). At the global scale, a Questionable rank qualifier (Q) can be used to denote uncertainty in the conservation status rank (e.g., G2Q). Taxa not ranked at the Global or State levels were noted as "GNR" or "SNR", respectively. Ranks at the global and state scales are given in the text when available, and in Tables 1, 2, and S3.

\section{Results}

Our annotated list includes records from 142 georeferenced sites in Georgia (121 caves and 21 wells or springs) and several non-georeferenced sites, totaling 281 described species (228 invertebrates and 53 vertebrates). Of these, 51 are troglobionts. In addition to the many new records we report here, we also provide a summary of all confirmed records of subterranean faunal biodiversity in Georgia. Our summary includes the first review of vertebrates in caves in Georgia and new occurrence records for many invertebrate species. We also highlight potentially new, as yet undescribed species that have been reported in literature or that we collected. With these data, we discuss conservation issues related to cave biodiversity in Georgia. Note that, in this paper, we limit our discussion to fauna (i.e., Kingdom Animalia); data on cellular slime molds and fungi from Georgia caves are presented in Reeves et al. (2000).

The Annotated List summarizes Tables S2 and S3 and, for many species, adds additional commentary on ecology, distribution, and systematics. The source for each record reported in the Annotated List is indicated in Table S2. With a few exceptions, we omitted records not identified to the genus or species level from the annotated list, although those records are included in Table S2. In cases where two or more studies reported a particular genus from a cave, but not all studies identified those specimens to the species level, we only included the more specific record in the Annotated List. Not all records could be identified to species level. Those at coarser taxonomic resolution were due to lack of available taxonomic expertise, lack of specimens of required maturity or sex necessary for identification, or, in some cases, may represent undescribed species. Further commentary related to many of these taxa can be found in Holsinger and Peck (1971), Reeves et al. (2000), and Buhlmann (2001). New records reported in the literature for the first time are indicated with an asterisk. 


\section{Annotated List of Fauna from Caves and other Subterranean Habitats of Georgia}

Phylum Annelida

Class Clitellata

Order Branchiobdellida

Family Branchiobdellidae

Localities: Dade Co.: Howards Waterfall Cave (GDD34), Hurricane

Cave (GDD62); Washington Co.: Tennile Caves (GWS20); Decatur Co.:

Climax Cave (GDC36).

Comments: These were collected as ectoparasites on crayfish (Holt, 1973; Reeves and Reynolds, 1999).

Order Opisthopora

Family Lumbricidae

Genus Aporrectodea

Aporrectodea trapezoides (Dugés, 1828) (ED) Southern Worm Localities: Dade Co.: Howards Waterfall Cave (GDD34), Morrison Cave (GDD86); Walker Co.: Horseshoe Cave (GWK12).

Comments: This species has been reported from caves in Georgia, Illinois, Missouri, and North Carolina (Peck and Lewis, 1978; Reynolds, 1994; Reeves and Reynolds, 1999; Reeves et al., 2000).

\section{Aporrectodea sp. (ED) An Earthworm}

Localities: Walker Co.: Spooky Cave (GWK494).

Comments: This may be $A$. trapezoides or another species.

\section{Genus Bimastos}

Bimastos tumidus (Eisen, 1874) (ED) An Earthworm

Localities: Bartow Co.: Kingston Saltpeter Cave (GBT11).

Comments: This species was collected on woody debris by Reeves and Reynolds (1999). It has also been reported from caves in Alabama, Tennessee, and Virginia (Peck, 1989; Reynolds, 1994).

Bimastos zeteki (Smith \& Gittins, 1915) (ED) An Earthworm Localities: Dade Co.: Cemetery Pit (GDD64).

Comments: This species was found in the soil at the bottom of the entrance pit at Cemetery Cave (Reeves and Reynolds, 1999).

\section{Genus Dendrobaena}

Dendrobaena octaedra (Savigny, 1826) (ED) Octagonal-tail Worm

Localities: Dade Co.: Cemetery Pit (GDD64).

Comments: This species has been reported from caves in Georgia and North Carolina (Reynolds, 1994; Reeves and Reynolds, 1999).

\section{Genus Dendrodrilus}

Dendrodrilus rubidus (Savigny, 1826) (TP) European Barkworm

Localities: Chattooga Co.: Parkers Cave (GKH119)*; Dade Co.: Boxcar Cave (GDD69)* Howards Waterfall Cave (GDD34), Hurricane Cave (GDD62); Decatur Co.: Climax Cave (GDC36); Gordon Co.: Rusty Cable Cave (GGO297)*; Grady Co.: Maloys Waterfall Cave (GGR27)*; Walker Co.: Goat Cave (GWK184), Horseshoe Cave (GWK12).

Comments: This species has also been reported from several caves in Georgia, Illinois, Missouri, North Carolina, Tennessee, and New Brunswick, Canada (McAlpine and Reynolds, 1977; Peck and Lewis, 1978; Reynolds, 1994; Reeves and Reynolds, 1999; Reeves et al., 2000).

\section{Genus Lumbricus}

\section{Lumbricus rubellus Hoffmeister, 1843 (ED) Nightcrawler}

Localities: Bartow Co.: Anthonys Cave (GBT175); Dade Co.: Howards Waterfall Cave (GDD34); Walker Co.: Horseshoe Cave (GWK12).

Comments: This species has been reported from caves in Georgia, Illinois, and North Carolina (Peck and Lewis, 1978; Reynolds, 1994; Reeves et al., 2000).

\section{Genus Octolasion}

Octolasion tyrtaeum (Savigny, 1826) (ED) Woodland White Worm

Localities: Dade Co.: Johnsons Crook Cave (GDD17).

Comments: This species has been reported from caves in Georgia, Illinois, North Carolina, and Tennessee (Holsinger and Peck, 1971; Peck and Lewis, 1978; Reynolds, 1994; Reeves, 2000; Lewis, 2005).
Family Megascolecidae

Genus Amynthas

Amynthas minimus (Horst, 1893) (ED) An Earthworm

Localities: Dade Co.: Howards Waterfall Cave (GDD34).

Comments: This species was collected in soil with woody debris below a drip pool (Reeves and Reynolds, 1999).

Family Sparganophilidae

Genus Sparganophilus

Sparganophilus tamesis Benham, 1892 (SX/AC) An Aquatic Worm

Localities: Dade Co.: Boxcar Cave (GDD69)*.

Comments: This species is common in mud sediments next to streams.

\section{Order Tubificida}

Family Naididae

Genus Arcteonais

Arcteonais lomondi Martin, 1907 (SP) An Aquatic Worm

Localities: Bartow Co.: Anthonys Cave (GBT175).

Comments: This aquatic worm was collected from mammal feces in a drip pool (Reeves et al., 2000).

Phylum Arthropoda

Subphylum Chelicerata

Class Arachnida

Order Araneae

Family Agelenidae

Genus Coras

Coras cf. juvenilis (Keyserling, 1881) (TX?) A Funnel Weaver Spider

Localities: Walker Co.: Fricks Cave (GWK14).

Comments: Questionable identification; large southern range expansion if validated.

Coras sp. (TX?) A Funnel Weaver Spider

Localities: Dade Co.: Byers Cave (GDD66).

Family Araneidae

Genus Araniella

Araniella sp. (TX/AC) An Orbweaver Spider

Localities: Walker Co.: Harrisburg Cave (GWK85).

Genus Tegenaria

Tegenaria domestica (Clerck, 1757) (TP/TX) Barn Funnel Weaver

Localities: Walker Co.: Hickman Gulf Cave.

Genus Wadotes

Wadotes cf. calcaratus (Keyserling, 1887) (AC) A Hacklemesh Weaver Spider

Localities: Dade Co.: Johnsons Crook Cave (GDD17).

Conservation status: IUCN: Not Evaluated; NatureServe: G5 (SNR in Georgia).

Comments: Questionable identification; large southern range expansion if true.

Wadotes saturnus Bennett, 1987 (TX?) A Hacklemesh Weaver

Spider

Localities: Dade Co.: Sittons Cave (GDD9)*.

Family Antrodiaetidae

Genus Antrodiaetus

Antrodiaetus unicolor (Hentz, 1842) (TP) Folding-Door Spider

Localities: Dade Co.: Howards Waterfall Cave (GDD34); Walker Co.: Fricks Cave (GWK14).

Family Clubionidae

Genus Elaver

Elaver excepta (L. Koch, 1866) (TP) Spiny Sac Spider

Localities: Chattooga Co.: Parkers Cave (GKH119)*; Dade Co.: Upper Valley Cave (GDD135).

Conservation status: IUCN: Not Evaluated; NatureServe: G5 (SNR in Georgia). 
Family Ctenidae

Genus Anahita

Anahita punctulata (Hentz, 1844) (AC) Southeastern Wandering Spider

Localities: Dade Co.: Hurricane Cave (GDD62)*.

Conservation status: IUCN: Not Evaluated; NatureServe: G4 (SNR in Georgia).

Family Cybaeidae

Genus Calymmaria

Calymmaria persica (Hentz, 1847) (TP/TX) A Dwarf Sheet Spider

Localities: Chattooga Co.: Parkers Cave (GKH119); Dade Co.: Byers Cave (GDD66), Rusty's Cave (GDD70); Walker Co.: Bible Springs Cave (GWK74), Four Kings Cave (GWK77)*, Mountain Cove Farm Cave No. 1 (GWK73).

Calymmaria sp. (TP/TX) A Dwarf Sheet Spider

Localities: Dade Co.: Boxcar Cave (GDD69)*; Walker Co.: Bee Rock Cave (GWK123) ${ }^{\star}$, Nash Waterfall Cave (GWK72).

Comments: This may be $C$. persica or another species.

Family Desidae

Genus Metaltella

Metaltella simoni (Keyserling, 1878) (AC) Hacklemesh Weaver

Localities: Grady Co.: Glory Hole Cave (GGR56).

Comments: This species is native to South America and introduced into the United States.

Family Hahniidae

Genus Cicurina

Cicurina arcuata Keyserling, 1887 (TPIAC) Curved Meshweaver Localities: Floyd Co.: Cave Springs Cave (GFL18).

Conservation status: IUCN: Not Evaluated; NatureServe: G5 (SNR in Georgia).

Cicurina pallida Keyserling, 1887 (TP/TX) Pallid Funnel-web

Spider

Localities: Randolph Co.: Griers Cave (GRA40).

Comments: Questionable identification; large southern range expansion if true.

Cicurina sp. (TP/TX) A Meshweaver Spider

Localities: Dade Co.: Byers Cave (GDD66).

Family Halonoproctidae

Genus Cyclocosmia

Cyclocosmia truncata (Hentz, 1841) (ED) Ravine Trapdoor Spider

Localities: Walker Co.: Missing Evan Well Cave (GWK488)*.

Family Hypochilidae

Genus Hypochilus

Hypochilus thorelli Marx, 1888 (TX) Thorell's Lampshade-web Spider

Localities: Dade Co.: Boxcar Cave (GDD69), Byers Cave (GDD66), Sittons Cave (GDD9).

Conservation status: IUCN: Not Evaluated; NatureServe: G4 (SNR in Georgia).

Comments: These spiders can be found near cave entrances where they build webs on rocky substrates. The species ranges from northeast Alabama to southeastern Kentucky (Hedin, 2001).

Family Leptonetidae

Genus Appaleptoneta

Appaleptoneta fiskei (Gertsch, 1974) (TB)

Localities: Walker Co.: Harrisburg Cave (GWK85), Pettijohns Cave (GWK29).

Comments: Endemic to Georgia and known only from these sites in Walker County (Ledford et al., 2011).

\section{Genus Ozarkia}

Ozarkia georgia (Gertsch, 1974) (TB)

Localities: Dade Co.: Byers Cave (GDD66), Kilpatrick Cave (GDD67), Rusty's Cave (GDD70).

Comments: Endemic to Georgia and known only from these sites in Dade County (Ledford et al., 2011).
Family Linyphiidae

Genus Anibontes

Anibontes sp. (TX/AC) A Sheetweb Spider

Localities: Chattooga Co.: Parkers Cave (GKH119)*.

Genus Anthrobia

Anthrobia sp. (TP/TX) A Sheetweb Spider

Localities: Bartow Co.: Kingston Saltpeter Cave (GBT11).

Genus Bathyphantes

Bathyphantes pallidus (Banks, 1892) (TX) Pale Sheetweb Weaver

Localities: Dade Co.: Howards Waterfall Cave (GDD34)*.

Conservation status: IUCN: Not Evaluated; NatureServe: G5 (SNR in Georgia).

Genus Centromerus

Centromerus denticulatus (Emerton, 1909) (TP) Toothy Spurred Sheetweaver

Localities: Walker Co.: Horseshoe Cave (GWK12).

Comments: This record from Holsinger and Peck (1971) is likely incorrect.

Centromerus latidens (Emerton, 1882) (TX) Elephant Spurred Sheetweaver

Localities: Bartow Co.: Davis Farm Cave (GBT222)*; Chattooga Co.: Parkers Cave (GKH119)*; Grady Co.: Maloys Waterfall Cave (GGR27)*;

Polk Co.: White River Cave (GPO7)*; Walker Co.: Screech Owl Cave (GWK205)*.

Conservation status: IUCN: Not Evaluated; NatureServe: G5 (SNR in Georgia).

\section{Genus Mermessus}

Mermessus maculatus (Banks, 1892) (TP) Spotted Harvester Money Spider

Localities: Bartow Co.: Busch Cave (GBT611), Davis Farm Cave (GBT222)*; Decatur Co.: Climax Cave (GDC36); Grady Co.: Maloys Waterfall Cave (GGR27).

\section{Genus Neriene}

Neriene radiata (Walckenaer, 1841) (AC) Filmy Dome Spider

Localities: Gordon Co.: Jack Crider Cave (GGO298)*.

Conservation status: IUCN: Not Evaluated; NatureServe: G5 (SNR in Georgia).

Genus Phanetta

Phanetta subterranea (Emerton, 1875) (TB) Subterranean Sheetweb Spider

Localities: Dade Co.: Byers Cave (GDD66), Caboose Cave (GDD475)*, Howards Waterfall Cave (GDD34), Johnsons Crook Cave (GDD17), Morrison Cave (GDD86), Sittons Cave (GDD9); Floyd Co.: Cave Springs Cave (GFL18); Walker Co.: Cave Spring Cave (GWK94), Fricks Cave (GWK14), Harrisburg Cave (GWK85), Mouldy Bat Pit (GWK257)*, Pigeon Cave (GWK57).

Conservation status: IUCN: Not Evaluated; NatureServe: G5 (SNR in Georgia).

Comments: Widespread and common in caves across the Appalachians and Interior Low Plateaus (Miller, 2005). This species is known from more counties than any other troglobiont in eastern North America (Christman and Culver, 2001).

\section{Genus Porrhomma}

Porrhomma cavernicola (Keyserling, 1886) (TB) Appalachian Cave Spider

Localities: Bartow Co.: Kingston Saltpeter Cave (GBT11).

Conservation status: IUCN: Not Evaluated; NatureServe: G5 (SNR in Georgia).

Comments: Widespread in caves of the southern Appalachians, extending to Indiana and Illinois. It is more common in caves in West Virginia and Virginia, and only occasionally encountered in caves in Tennessee, Alabama, and Georgia (Miller, 2005).

Family Lycosidae

Genus Pirata

Pirata alachuus Gertsch \& Wallace, 1935 (AC) A Pirate Wolf Spider Localities: Dade Co.: Wild Bills Dakota Cave (GDD596)*. 
Pirata sp. (AC) A Pirate Wolf Spider

Localities: Walker Co.: Horseshoe Cave (GWK12).

\section{Genus Piratula}

Piratula insularis Emerton, 1885 (AC) Lonely Wolf Spider

Localities: Grady Co.: Maloys Waterfall Cave (GGR27).

Family Mysmenidae

Genus Maymena

Maymena ambita (Barrows, 1940) (TP) Minute Cave Spider

Localities: Walker Co.: Ellisons Cave (GWK51), Horseshoe Cave (GWK12).

\section{Family Nesticidae \\ Genus Eidmannella}

Eidmannella pallida (Emerton, 1875) (TP) Pallid Cobweb Spider

Localities: Catoosa Co.: Crane Cave (GCZ80)*; Chattooga Co.: Subligna Cave (GKH145)*; Dade Co.: Howards Waterfall Cave (GDD34); Decatur Co.: Climax Cave (GDC36); Floyd Co.: Cave Springs Cave (GFL18); Grady Co.: Maloys Waterfall Cave (GGR27)*; Randolph Co.: Griers Cave (GRA40).

Comments: This troglophilic species is widespread in North America, Central America, and the Caribbean (Gertsch, 1984).

\section{Genus Gaucelmus}

Gaucelmus augustinus Keyserling, 1884 (TP) A Cave Cobweb Spider

Localities: Decatur Co.: Climax Cave (GDC36); Houston Co.: Limerock

Cave; Washington Co.: Tennile Caves (GWS20).

Conservation status: IUCN: Not Evaluated; NatureServe: G3G4 (SNR in Georgia).

Comments: This species is a troglophile and is common in caves from Florida to Texas, through Central America to Panama, and parts of the Caribbean (Gertsch, 1984).

\section{Genus Nesticus}

Nesticus georgia Gertsch, 1984 (TB) Georgia Cave Spider

Localities: Dade Co.: Case Cavern (GDD1), Sittons Cave (GDD9), unnamed cave near Trenton.

Conservation status: IUCN: Not Evaluated; NatureServe: G1G2 (SNR in Georgia).

Comments: This eyeless spider is endemic to Georgia and is a member of the southern Appalachian radiation of Nesticus that includes numerous troglobiotic species (Gertsch, 1984; Hedin, 1997). Some information regarding feeding and reproduction has been reported (Reeves, 1999; Carver et al., 2016).

\section{Nesticus sp. (TB/TP) A Cave Cobweb Spider}

Localities: Dade Co.: Rusty's Cave (GDD70**; Walker Co.: Anderson Spring Cave (GWK46), Fingerhole Cave (GWK259)*, Matthews Sink $($ GWK133)*, Mouldy Bat Pit (GWK257)*, Pigeon Cave (GWK57), Bee Rock Cave (GWK123)*, Lula Falls Cave (GWK617)*.

Comments: These records represent at least two undescribed species. Records from Pigeon Mountain (Anderson Spring Cave, Matthews Sink and Pigeon Cave) are an undescribed eyeless species. Additional records from Pigeon Mountain (Fingerhole Cave and Mouldy Bat Pit) may also correspond to this species. The specimens from Lookout Mountain (Lula Falls Cave) have eyes and likely represent a second undescribed species. The affinity of the Rusty's Cave record is unclear.

\section{Family Pholcidae}

Genus Pholcus

Pholcus dade Huber, 2011 (TP) A Cellar Spider

Localities: Dade Co.: Byers Cave (GDD66), Sittons Cave (GDD9); Walker Co.: Fricks Cave (GWK14), Spooky Cave (GWK494).

Comments: Huber (2011) notes the Byers Cave specimen is tentatively assigned to this species.

Pholcus lanieri Huber, 2011 (TP) Lanier's Cellar Spider

Localities: Dade Co.: Hurricane Cave (GDD62).

Comments: Known only from Hurricane Cave, the type locality (Huber, 2011).
Pholcus sp. (TP/TX) A Cellar Spider

Localities: Bartow Co.: Ladds Lime Cave (GBT384-GBT389); Catoosa Co.: Chapmans Cave (GCZ25)*; Dade Co.: Little Nicka Cave

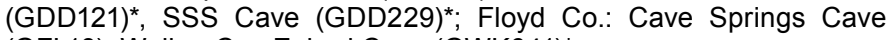
(GFL18); Walker Co.: Zahnd Cave (GWK641)*.

Comments: Huber (2011) describes several new Pholcus species from Georgia.

\section{Family Salticidae}

Genus Maevia

Maevia inclemens (Walckenaer, 1837) (AC) Dimorphic Jumper

Localities: Walker Co.: Hickman Gulf Cave.

\section{Family Tetragnathidae}

Genus Meta

\section{Meta ovalis (Gertsch, 1933) (TP) Cave Orbweaver}

Localities: Dade Co.: Byers Cave (GDD66), Caboose Cave (GDD475)*, Goat Cave (GWK184), Howards Waterfall Cave (GDD34), Morrison Cave (GDD86), Sittons Cave (GDD9); Walker Co.: Fingerhole Cave $($ GWK259)*, Four Kings Cave (GWK77)*, Fricks Cave (GWK14), Harrisburg Cave (GWK85), Mountain Cove Farm Cave No. 1 (GWK73), Nash Waterfall Cave (GWK72), Pigeon Cave (GWK57), Rocky Cave $($ GWK496)*, Spooky Cave (GWK494).

Conservation status: IUCN: Not Evaluated; NatureServe: G5 (SNR in Georgia).

Comments: This species is widely distributed and found in many caves in the central and eastern United States.

Family Theridiidae

Genus Achaearanea

Achaearanea sp. (?) A Cobweb Spider

Localities: Dade Co.: Byers Cave (GDD66).

\section{Genus Cryptachaea}

Cryptachaea porteri (Banks, 1896) (TX) A Cobweb Spider

Localities: Dade Co.: Hooker Cave (GDD90)* Walker Co.: Fricks Cave (GWK14).

\section{Genus Parasteatoda}

Parasteatoda tepidariorum (Koch, 1841) (TP) Common House Spider

Localities: Bartow Co.: Ladds Lime Cave (GBT384-GBT389); Catoosa Co.: Chapmans Cave (GCZ25)*; Dade Co.: Sittons Cave (GDD9); Gordon Co.: Roberts Cave (GGO147); Polk Co.: White River Cave (GPO7); Walker Co.: Bible Springs Cave (GWK74).

\section{Parasteatoda sp. (TP/TX) A Tangle Web Spider}

Localities: Bartow Co.: Anthonys Cave (GBT175), Davis Farm Cave (GBT222)*; Walker Co.: Lofton Cave (GWK281)*.

Comments: This may be $P$. tepidariorum or another species.

\section{Family Theridiosomatidae}

Genus Theridiosoma

Theridiosoma gemmosum (Koch, 1877) (TX) Common Eastern Ray Spider

Localities: Walker Co.: Horseshoe Cave (GWK12).

Conservation status: IUCN: Not Evaluated; NatureServe: G5 (SNR in Georgia).

\section{Family Zoropsidae}

Genus Liocranoides

Liocranoides gertschi Platnick, 1999 (TP) Gertsch's Two-clawed Cave Spider

Localities: Dade Co.: Byers Cave (GDD66), Hurricane Cave (GDD62), Sittons Cave (GDD9); Walker Co.: Horseshoe Cave (GWK12).

Comments: The range of $L$. gertschi extends to northern Alabama (Platnick, 1999). Yancey et al. (2018) described egg sacs for Liocranoides from Tennessee. 
Liocranoides unicolor Keyserling, 1881 (TB) A Two-clawed Cave Spider

Localities: Chattooga Co.: Parkers Cave (GKH119); Dade Co.: Byers Cave (GDD66), Morrison Cave (GDD86); Walker Co.: Bible Springs Cave (GWK74), Hickman Gulf Cave, Horseshoe Cave (GWK12), Mountain Cove Farm Cave No. 1 (GWK73).

Conservation status: IUCN: Not Evaluated; NatureServe: G5 (SNR in Georgia).

Comments: Platnick (1999) indicated that $L$. unicolor ranges no further south than central Tennessee; these records may correspond to $L$. gertschi or an undescribed species.

\section{Liocranoides sp. (TB/TP) A Two-clawed Cave Spider}

Localities: Bartow Co.: Davis Farm Cave (GBT222)*; Chattooga Co.: Parkers Cave (GKH119)*; Dade Co.: Case Cavern (GDD1)*, Hooker Cave (GDD90)*, Howards Waterfall Cave (GDD34)*, Kirchmeyer Cave $($ GDD196)*, Rusty's Cave (GDD70)*, SSS Cave (GDD229)*; Walker Co.: Anderson Spring Cave (GWK46), Ellisons Cave (GWK51)*, Fricks Cave (GWK14)*, Lofton Cave (GWK281)*, Pettijohns Cave (GWK29), Smartt Farm Cave (GWK124)*.

Comments: These records may be $L$. gertschi or an undescribed species.

\section{Order Opiliones}

Family Phalangodidae

Genus Bishopella

Bishopella laciniosa (Crosby and Bishop, 1924) (TP) Bishop's Harvestman

Localities: Bartow Co.: Busch Cave (GBT611); Catoosa Co.: Crane Cave (GCZ80)*; Chattooga Co.: Blowing Springs Cave (GKH54), Parkers Cave $(\mathrm{GKH} 119)^{*}$, Scoggins II Cave (GKH405)*, Subligna Cave (GKH145)*; Dade Co.: Byers Cave (GDD66), Caboose Cave (GDD475)*, Hooker Cave (GDD90*), Howards Waterfall Cave (GDD34), Hurricane Cave (GDD62), Kirchmeyer Cave (GDD196)*, Limestone Caverns (GDD140)*, Lower Valley Cave (GDD136)*, Rusty's Cave (GDD70)*, Sittons Cave (GDD9); Floyd Co.: Cave Springs Cave (GFL18); Gordon Co.: Plainville Cave (GGO83)*; Polk Co.: White River Cave (GPO7); Walker Co.: Anderson Spring Cave (GWK46), Bee Rock Cave (GWK123)*, Bible Springs Cave (GWK74), Ellisons Cave $($ GWK51)*, Fricks Cave (GWK14)*, Harrisburg Cave (GWK85), Horseshoe Cave (GWK12), LittleJohn Cave (GWK280)*, Pettijohns Cave (GWK29), Smartt Farm Cave (GWK124)*.

Comments: This species is known from surface and cave habitats across the southern Appalachians (Hedin and Thomas, 2010).

\section{Bishopella sp. (TP/TX)}

Localities: Bartow Co.: Anthonys Cave (GBT175); Dade Co.: Case Cavern (GDD1), Sittons Cave (GDD9); Walker Co.: Ellisons Cave (GWK51), Nash Waterfall Cave (GWK72), Pigeon Cave (GWK57).

Comments: These records may be $B$. laciniosa or an undescribed species.

\section{Genus Crosbyella}

Crosbyella spinturnix (Crosby and Bishop, 1924) (TP) A Harvestman

Localities: Decatur Co.: Climax Cave (GDC36); Gordon Co.: Rusty Cable Cave (GGO297)*; Grady Co.: Glory Hole Cave (GGR56)*, Maloys Waterfall Cave (GGR27).

Comments: This troglophile has been reported from caves in Alabama, Arkansas, Florida, and Georgia (Crosby and Bishop, 1924; Goodnight and Goodnight, 1942; Peck, 1970; Holsinger and Peck, 1971; Peck, 1989; Graening et al., 2011).

\section{Family Sabaconidae \\ Genus Sabacon \\ Sabacon sp. (TP/TX) A Harvestman}

Localities: Walker Co.: Goat Cave (GWK184).

Comments: This record may represent an undescribed species or one of two described species: S. cavicolens or S. jonesi. Sabacon cavicolens primarily occurs in rocky and forested cool surface habitat across the central and northeastern USA and in southeastern Canada (Koponen, 1995; Shear, 1975), but has also been reported from caves across its distribution, with confirmed records from Ontario, Canada (Peck, 1988), Arkansas (Shear, 1975; Peck and Peck, 1982), and Ten- nessee (Niemiller et al., unpublished data). Sabacon jonesi is known only from one cave in Madison County, Alabama (Goodnight and Goodnight, 1942). If our record from Goat Cave represents either of the previously described species, then it will represent a range extension and new state record.

\section{Family Sclerosomatidae \\ Genus Leiobunum \\ Leiobunum sp. (TX) A Harvestman}

Localities: Bartow Co.: Anthonys Cave (GBT175).

Comments: Several species of Leiobunum are known to use subterranean features to seek shelter. They often aggregate in large clusters of individuals $(>100)$, either as overwintering populations, or presumably to seek daytime shelter during hot dry summer weather (e.g., Holmberg et al., 1984). Aggregations of Leiobunum are typically only found in shallow karst features or in the transition or entrance zones of caves. This clustering behavior has yet to be reported from a Georgia cave. Reeves et al. (2000) reported a single immature specimen collected from Anthonys Cave in May 1999, but did not note whether an aggregation of individuals was observed.

\section{Order Pseudoscorpiones}

\section{Family Chernetidae}

Genus Hesperochernes

Hesperochernes mirabilis (Banks, 1895) (TB) Southeastern Cave Pseudoscorpion

Localities: Catoosa Co.: Chickamauga Cave $(\mathrm{GCZ106})^{*}$, Crane Cave (GCZ80); Chattooga Co.: Parker Cave (GKH119), Scoggins II Cave (GKH405)*; Dade Co.: Howards Waterfall Cave (GDD34), Johnsons Crook Cave No. 2 (GDD19), Kirchmeyer Cave (GDD196)*, Morrison Cave (GDD86), Morrison Spring Cave (GDD110), SSS Cave (GDD 229)*; Murray Co.: Major Pullims Cave (GMA3)*; Walker Co.: Battlefield Cave Spring (GWK203), Fricks Cave (GWK14), Hickman Gulf Cave (GWK204), Mountain Cove Farm Cave No. 1 (GWK73), Pigeon Cave $(\mathrm{GWK57})^{*}$.

Conservation status: IUCN: Not Evaluated; NatureServe: G5 (SNR in Georgia).

Comments: This species is distributed widely in northern Georgia caves. It is typically associated with bat guano, active rodent nests, and scat. Holsinger and Peck's (1971) record from Johnsons Crook Cave (GDD17) was in error and repeated by Reeves et al. (2000); this record was based on specimen WM1347.01 in W.B. Muchmore's collection, with original collection label "Johnson Crook Cave \#2, $4.5 \mathrm{mi}$ NE Rising Fawn" (Muchmore, unpublished data). A bioinventory of Johnsons Crook Cave (GDD17) on 25 June 2016 did not recover this species or find its typical habitat. The record from Battlefield Cave Spring (GWK203) was previously reported as "Cave Spring" and "Cave Spring Cave" (Holsinger and Peck, 1971; Reeves et al., 2000). Holsinger and Peck's (1971) records for Pseudozaona sp. are here relegated to this species; Chelifer mirabilis Banks, 1895 was transferred by Hoff (1946) to Pseudozaona and then by Muchmore (1974) to Hesperochernes. Records in W.B. Muchmore's catalog (unpublished data) identified as "Hesperochernes sp." are here placed in $H$. mirabilis on the basis of ongoing work with this genus (Stephen, unpublished data). The last known collection in Georgia was in 2015 (this study); previously, the last published record from the state was collected in 1998 (Muchmore, unpublished data; Reeves et al., 2000).

\section{Family Chthoniidae}

Genus Aphrastochthonius

Aphrastochthonius sp. (?) A Pseudoscorpion

Localities: Dade Co.: Byers Cave (GDD66), Longs Rock Wall Cave (GDD101)*.

Comments: These records appear to represent undescribed species (Stephen, unpublished data). No described species of this genus are known to occur in Georgia.

\section{Genus Apochthonius}

Apochthonius minor Muchmore, 1976 (TX?) A Pseudoscorpion

Localities: Chattooga Co.: Parker Cave (GKH119); Dade Co.: Morrison Cave (GDD86).

Conservation status: IUCN: Not Evaluated; NatureServe: G1 (SNR in Georgia).

Comments: This species is only definitively known from organic debris in entrance zones of one cave and one karst feature in Georgia. A se- 
ries of females and nymphs (catalog number WM8548.01) that W.B. Muchmore (unpublished data) tentatively identified as "Apochthonius minor?" was reported by Lewis (2005) as A. minor from a cave in Van Buren County, Tennessee; this record may be $A$. minor or a species not yet described. All confirmed occurrences of this species are from the type series in Parker Cave and Morrison Cave that were collected in summer 1967 (Muchmore, 1976, unpublished data).

\section{Apochthonius sp. (TX?) A Pseudoscorpion}

Localities: Chattooga Co.: Parker Cave (GKH119).

Comments: From the same 1967 collections in the entrance of Parker Cave that recovered types for $A$. minor, Muchmore (1976, unpublished data) also identified two larger adult specimens to the genus Apochthonius (catalog numbers WM1270.01 and WM1275.01). These may represent undescribed species.

\section{Genus Chthonius}

\section{Chthonius sp. (?) A Pseudoscorpion}

Localities: Walker Co.: Horseshoe Cave (GWK12); Dade Co.: Howards Waterfall Cave (GDD34).

Comments: Of this globally distributed, diverse genus (264 species in Harvey (2013)), in eastern North America four species are known, of which two are native: $C$. paludis and $C$. virginicus. These records were reported by Reeves et al. (2000) from collections made in 1998, and are the only published occurrences of Chthonius in Georgia. They also appear to represent the first observations of this genus from a North American cave (Harvey, 2013; GBIF.org, 2019; Muchmore, unpublished data). Reeves et al. (2000) reported the records as C. paludis from Horseshoe Cave and C. virginicus from Howards Waterfall Cave. Both were identified by W.B. Muchmore, but in his catalog (unpublished data) he gave only tentative specific identifications. The Horseshoe Cave " $C$. paludis?" identification was based on a single female (catalog number WM8265.01) that Muchmore noted to be abnormally slender for this species. The "C. virginicus?" identification from Howards Waterfall Cave was based on a single nymph (catalog number WM8267.01). If these tentative identifications are correct, then each would represent large range extensions, new records of both species in Georgia, and new records of both species from caves.

\section{Genus Kleptochthonius}

Kleptochthonius magnus Muchmore, 1966 (TB) A Cave Pseudoscorpion

Localities: Walker Co.: Mountain Cove Farm Cave No. 1 (GWK73).

Conservation status: IUCN: Not Evaluated; NatureServe: G1 (SNR in Georgia).

Comments: This species is known from four caves located in southeastern Tennessee, northeastern Alabama, and northwestern Georgia. The type locality is in Tennessee. It is a small, pale species, with two pairs of eyes. The last known collection in Georgia was in 1967 (Holsinger and Peck, 1971; Muchmore, unpublished data).

\section{Kleptochthonius sp. (?) A Pseudoscorpion}

Localities: Walker Co.: Mountain Cove Farm Cave No. 1 (GWK73)*; Walker Co.: Rumble Rock Canyon Cave (GWK627)*.

Comments: Subterranean species of Kleptochthonius tend to have geographically constrained distributions, sometimes restricted to a single cave. Each of these records may represent an undescribed species.

\section{Genus Mundochthonius}

\section{Mundochthonius sp. (?) A Pseudoscorpion}

Localities: Chattooga Co.: Parker Cave (GKH119)*.

Comments: In North America, there are nine Mundochthonius species, of which three occur in caves (Harvey, 1990, 2013). This is the first record of Mundochthonius in Georgia. Our sampling efforts across northwestern and southwestern Georgia in caves and on the surface (sampling leaf litter, deadwood, and under live tree bark) did not recover Mundochthonius (Stephen, unpublished data). In June 1967, along with Hesperochernes pseudoscorpions and Miktoniscus isopods, several specimens of Mundochthonius were collected from a Berlese extraction of debris near the entrance of Parker Cave. These were identified by W.B. Muchmore (catalog number WM2367.01, unpublished data). These specimens may represent range extensions of surface species or undescribed subterranean diversity.
Family Neobisiidae

Genus Lissocreagris

Lissocreagris subatlantica (Chamberlin, 1962) (TX) A Pseudoscorpion

Localities: Chattooga Co.: Parker Cave (GKH119).

Conservation status: IUCN: Not Evaluated; NatureServe: G2G4 (SNR in Georgia).

Comments: This species is known from five collection events, of which four are from within caves or in the entrance area of a cave. In Georgia it was collected from organic debris in the entrance of Parker Cave (Muchmore, 1969). It is a small, pale species, with two pairs of reduced eyes (Chamberlin, 1962). The last known collection in Georgia was in 1967 (Muchmore 1969, unpublished data).

\section{Lissocreagris sp. (TB/TP) A Pseudoscorpion}

Localities: Walker Co.: Pettijohns Cave (GWK29)*.

Comments: This appears to represent an undescribed species. It was collected by S. Peck and A. Fiske in a pitfall trap active 10-21 June 1967, identified by W.B. Muchmore (unpublished data) as "Lissocreagris n. sp.", and listed as Microcreagris sp. by Holsinger and Peck (1971). In his catalog, Muchmore (unpublished data) originally identified the genus to Microcreagris and later changed this to Lissocreagris after this genus was erected by Ćurčić (see comments for Microcreagris). In his catalog, Muchmore briefly notes that the single adult female (catalog number WM1311.01) was small and eyeless.

\section{Genus Microcreagris}

Microcreagris (sensu lato) sp. (TP/TX) A Pseudoscorpion

Localities: Walker Co.: Mountain Cove Farm Cave No. 1 (GWK73)*. Comments: Ćurčić $(1981,1984,1989)$ and Muchmore and Cokendolpher (1995) transferred all but one species of subterranean North American Microcreagris into several genera erected by Ćurčić. Holsinger and Peck (1971) listed two records of unidentified Microcreagris, from Pettijohns Cave (GWK29) and Johnsons Crook Cave (GDD17), commenting "A single female of this undetermined species was collected". Their pseudoscorpion identifications were done by W.B. Muchmore; in his catalog (unpublished data), he identified a single female "Lissocreagris n. sp." collected from Pettijohns Cave in 1967 by S. Peck and A. Fiske (see comments for Lissocreagris). There is no mention in Muchmore's catalog of Microcreagris (or the replacement genera erected by Ćurčić, 1989) from Johnson Crook Cave. The new record from Mountain Cove Farm Cave No. 1 consisted of an isolated pedipalp (catalog number WM2990.02) collected from the stomach contents of a Eurycea lucifuga found in the dark zone of the cave. Muchmore tentatively identified it to Microcreagris.

\section{Microcreagris (sensu lato) sp. A Pseudoscorpion}

Localities: Dade Co.: Hooker Cave (GDD90)*.

\section{Genus Minicreagris}

Minicreagris pumila (Muchmore, 1969) (TX) A Pseudoscorpion

Localities: Chattooga Co.: Parker Cave (GKH119).

Comments: This species is known from the entrance zone of one cave and one surface locality in Alabama, and from organic debris in the entrance zone of Parker Cave (Muchmore, 1969). It was incorrectly listed as "Lissocreagris pumila" by Peck (1989). The species is small and pale, and has one pair of reduced eyes (Muchmore, 1969). The last known collection in Georgia was in 1967 (Holsinger and Peck, 1971; Muchmore, unpublished data). In transferring Microcreagris pumila into Minicreagris, Ćurčić (1989) misquoted Muchmore (1969) by listing an epigean Tennessee locality: the species is only known from Alabama and Georgia (Muchmore, 1969, unpublished data).

\section{Genus Novobisium}

Novobisium carolinense (Banks, 1895) (AC) A Pseudoscorpion

Localities: Dade Co.: Johnson Crook Cave (GDD17)*.

Comments: This record represents a range extension and the first report of this species from a cave. The species is widely distributed in the southeastern USA, where it is typically found in leaf litter. The only Georgia records were collected from the bottom of the pit entrance of Johnson Crook Cave in 2016 (this study). A trap set in the sink outside of Johnson Crook Cave in 1967 also collected an unidentified species of Novobisium (Muchmore, unpublished data). 
Order Ixodida

Family Argasidae

Genus Ornithodoros

Ornithodoros kelleyi (Cooley and Kohls, 1941) (SY) A Bat Tick

Localities: Decatur Co.: Climax Cave (GDC36).

Comments: This bat tick was collected in guano piles by Reeves et al.

(2000). The likely host was Myotis austroriparius.

Family Ixodidae

Genus Dermacentor

Dermacentor variabilis (Say, 1821) (SY) American Dog Tick

Localities: Dade Co.: Howards Waterfall Cave (GDD34).

Comments: This tick is a common ectoparasite of mammals.

\section{Genus Ixodes}

Ixodes cookei Packard 1869 (SY) American Castor Bean Tick

Localities: Walker Co.: Rocky Cave (GWK496).

Comments: This tick is a common ectoparasite of birds and mammals, including humans.

Order Mesostigmata

Family Laelapidae

Genus Laelaspis

Laelaspis sp. (TX/AC) A Mite

Localities: Dade Co.: Case Cavern (GDD1); Walker Co.: Pettijohns Cave (GWK29).

\section{Family Macrochelidae}

\section{Genus Macrocheles}

Macrocheles sp. (TX/AC) A Mite

Localities: Walker Co.: Fricks Cave (GWK14).

Comments: This mite was common on Myotis grisescens guano at

Fricks Cave (Reeves et al., 2000).

\section{Family Veigaiidae}

Genus Veigaia

Veigaia sp. (TX/AC) A Mite

Localities: Walker Co.: Nash Waterfall Pit (GWK360).

Comments: Reeves et al. (2000) collected a single specimen in 1995.

\section{Order Sarcoptiformes}

Family Acaridae

Genus Troglocoptes

Troglocoptes sp. (TX/AC) A Mite

Localities: Walker Co.: Fricks Cave (GWK14).

Comments: Reeves et al. (2000) reported this potentially undescribed mite from Myotis grisescens guano.

\section{Order Trombidiformes}

Family Rhagidiidae

Genus Rhagidia

Rhagidia sp. (TB?/TP) A Mite

Localities: Bartow Co.: Kingston Saltpeter Cave (GBT11); Dade Co.: Byers Cave (GDD66), Morrison Cave (GDD86); Walker Co.: Bible Springs Cave (GWK74), Pettijohns Cave (GWK29).

Comments: These records were reported by Holsinger and Peck (1971).

Family Trombiculidae

Genus Euschoengastia

Euschoengastia pipistrelli Brennan, 1947 (SY) A Chigger

Localities: Dade Co.: Howards Waterfall Cave (GDD34); Walker Co.: Fricks Cave (GWK14).

Comments: This species is an ectoparasite of Perimyotis subflavus.

\section{Genus Leptotrombidium}

Leptotrombidium myotis (Ewing, 1829) (SY) A Chigger

Localities: Bartow Co.: Anthonys Cave (GBT175).

Comments: This species is an ectoparasite and was reported feeding on Perimyotis subflavus by Reeves et al. (2000).

Subphylum Crustacea

Class Branchiopoda

Order Diplostraca

Family Daphniidae

Genus Daphnia

Daphnia sp. (TX/AC) A Common Water Flea
Localities: Bartow Co.: Anthonys Cave (GBT175).

Comments: Reeves et al. (2000) collected a single specimen from a drip pool.

\section{Class Malacostraca}

Superorder Peracarida

Order Amphipoda

Family Crangonyctidae

Genus Crangonyx

Crangonyx antennatus Cope and Packard, 1881 (SB) Appalachian

Valley Cave Amphipod

Localities: Catoosa Co.: Crane Cave (GCZ80)* Chattooga Co.: Chelsea Gulf Cave (GKH54); Dade Co.: Byers Cave (GDD66), Cemetery Pit (GDD64), Chambliss Cave (GDD321), Howards Waterfall Cave (GDD34), Hurricane Cave (GDD62)*, Johnsons Crook Cave (GDD17)*, Rusty's Cave (GDD70), Sittons Cave (GDD9), SSS Cave (GDD229)*, Upper Valley Cave (GDD135); Floyd Co.: Cave Springs Cave (GFL18); Walker Co.: Anderson Spring Cave (GWK46), Fricks Cave (GWK14), Gila Monster Cave (GWK379)*, Harrisburg Cave (GWK85), Horseshoe Cave (GWK12), Mountain Cove Farm Cave No. 1 (GWK73), Pettijohns Cave (GWK29), Spooky Cave (GWK494).

Conservation status: IUCN: Not Evaluated; NatureServe: G5 (SNR in Georgia).

Comments: This is a widespread stygobiotic species whose range extends through the Valley and Ridge from southwestern Virginia into northeastern Alabama. It is common in cave streams and pools (Zhang and Holsinger, 2003).

Crangonyx consimilis Zhang and Holsinger, 2003 (SX) An Amphipod

Localities: Dade Co.: Howards Waterfall Cave (GDD34)*.

Conservation status: IUCN: Not Evaluated; NatureServe: G4 (SNR in Georgia).

Comments: This record likely is a misidentification, as this species is not otherwise recorded east of the Cumberland Plateau (Zhang and Holsinger, 2003).

\section{Genus Stygobromus}

Stygobromus ackerlyi Holsinger, 1978 (SB) Ackerly's Cave Amphipod

Localities: Bartow Co.: Chert Chasm (GBT340); Floyd Co.: Cave Springs Cave (GFL18); Polk Co.: White River Cave (GPO7). Conservation status: IUCN: Not Evaluated; NatureServe: G1G2 (SNR in Georgia).

Comments: This stygobite is endemic to Georgia and known only from these sites in the Coosa River drainage.

Stygobromus dicksoni Holsinger, 1978 (SB) A Cave Amphipod Localities: Chattooga Co.: Chelsea Gulf Cave (GKH54); Dade Co.: Byers Cave (GDD66), Cemetery Pit (GDD64), Howards Waterfall Cave (GDD34), Johnsons Crook Cave (GDD17)*, Rusty's Cave (GDD70); Walker Co.: Pettijohns Cave (GWK29).

Conservation status: IUCN: Not Evaluated; NatureServe: G5 (SNR in Georgia).

Comments: The range of this stygobite extends into adjacent northeastern Alabama and southern Tennessee (Holsinger, 1978).

Stygobromus doughertyensis, Cannizzaro and Sawicki, 2019 (SB) Dougherty Plain Cave Amphipod

Localities: Dougherty County:: Radium Springs (GDG39).

Comments: This species is also known from Jackson Co., Florida.

Stygobromus grandis Holsinger, 1978 (SB) Parkers Cave Amphipod

Localities: Chattooga Co.: Parkers Cave (GKH119).

Conservation status: IUCN: Not Evaluated; NatureServe: G1 (SU in Georgia).

Comments: This stygobite is endemic to Georgia and known only from Parkers Cave (Holsinger, 1978).

Stygobromus minutus Holsinger, 1978 (SB) Pettijohns Cave Amphipod

Localities: Walker Co.: Nash Waterfall Cave (GWK72), Pettijohns Cave (GWK29).

Conservation status: IUCN: Not Evaluated; NatureServe: G2G3 (SU in Georgia). 
Comments: This stygobite is endemic to Georgia and known only from these sites on Pigeon Mountain (Holsinger, 1978).

\section{Stygobromus sp. (SB) A Cave Amphipod}

Localities: Dade Co.: Boxcar Cave (GDD69), Caboose Cave (GDD475). Comments: Reeves et al. (2000) suggest these records represent an undescribed species.

\section{Order Isopoda}

Family Armadilliidae

Genus Armadillidium

Armadillidium vulgare (Latreille, 1804) (TX) Common Pill-bug

Localities: Walker Co.: Horseshoe Cave (GWK12).

Comments: This common surface species was introduced from Europe and is now widespread in North America.

\section{Family Asellidae}

Genus Caecidotea

Caecidotea cyrtorhynchus (Fleming and Steeves, 1972) (SB) A

\section{Cave Isopod}

Localities: Walker Co.: Anderson Spring Cave (GWK46), Nash Waterfall Cave (GWK72), Pettijohns Cave (GWK29).

Conservation status: IUCN: Not Evaluated; NatureServe: G1 (SU in Georgia).

Comments: This stygobite is endemic to Georgia and known only from sites on Pigeon Mountain. The type locality is Pettijohns Cave.

Caecidotea hobbsi (Maloney, 1939) (SB) Hobbs Cave Isopod

Localities: DeKalb Co.: Spring on Walter Chandler Estate at Emory University.

Conservation status: IUCN: Not Evaluated; NatureServe: G2G3 (SNR in Georgia).

Comments: This stygobite is only reported from one site in Georgia. It is more commonly known from Florida (Steeves, 1964). This record may be in error, and likely represents $C$. putea instead (J. Lewis, pers. comm).

\section{Caecidotea nickajackensis Packard, 1881 (SB) Nickajack Cave Isopod}

Localities: Dade Co.: Johnsons Crook Cave (GDD17)*.

Conservation status: IUCN: Not Evaluated; NatureServe: GH (SNR in Georgia).

Comments: This species was presumed extinct after the flooding of Nickajack Cave in Marion County, Tennessee in the 1960s (Lewis, 2009) but was rediscovered in two caves near the junction of Tennessee, Alabama, and Georgia (Coleman and Zigler, 2015). This is the first record of the species in Georgia.

\section{Caecidotea putea Lewis, 2009 (SB) Econfina Springs Cave Iso- pod}

Localities: Cobb Co.: road cut spring, Kennesaw; Thomas Co.: Wells at Experimental Station, Metcalf.

Conservation status: IUCN: Not Evaluated; NatureServe: G1G2 (SNR in Georgia).

Comments: This stygobite is known from only three widely-dispersed sites, including one in Washington County, Florida (Lewis, 2009).

Caecidotea richardsonae Hay, 1901 (SB) Tennessee Valley Cave Isopod

Localities: Bartow Co.: seep $1 \mathrm{mi}$ NE of Adairsville; Chattooga Co.: Blowing Springs Cave (GKH54), Chelsea Gulf Cave (GKH54); Dade Co.: Byers Cave (GDD66), Cemetery Pit (GDD64)*, Howards Waterfall Cave (GDD34), Hurricane Cave (GDD62)*, Johnsons Crook Cave (GDD17), Lower Valley Cave (GDD136)*, Rusty's Cave (GDD70), Sittons Cave (GDD9)*, SSS Cave (GDD229)*; Floyd Co.: Cave Springs Cave (GFL18); Walker Co.: Blowing Springs Cave No. 1 (GWK41), Horseshoe Cave (GWK12), Mountain Cove Farm Cave No. 1 (GWK73). Conservation status: IUCN: Not Evaluated; NatureServe: G5 (SNR in Georgia).

Comments: Widespread species whose range extends through the Valley and Ridge from southwest Virginia to northeast Alabama (Lewis, 2009). Common in cave streams and pools.

\section{Caecidotea sp. (SB) A Cave Isopod}

Localities: Catoosa Co.: Chapmans Cave (GCZ25)*; Dade Co.: Longs Rock Wall Cave (GDD101)*; Mitchell Co.: USGS Well 11J012; Walker Co.: Ellisons Cave (GWK51).

Comments: The record from a well in Mitchell County was a female in the hobbsi species group (Fenolio et al. 2017).

\section{Genus Lirceus}

Lirceus sp. (SP/SX) An Isopod

Localities: Chattooga Co.: Blowing Springs Cave (GKH54); Dade Co.: Howards Waterfall Cave (GDD34)*; Walker Co.: Nash Waterfall Cave (GWK72).

Comments: These records are eyed, pigmented specimens. They are a species from the $L$. hargeri group that also occurs in Tennessee and Virginia (J. Lewis, pers. comm.).

\section{Family Cylisticidae}

Genus Cylisticus

Cylisticus convexus (De Geer, 1778) (TX) Curly Woodlouse

Localities: Bartow Co.: Anthonys Cave (GBT175); Dade Co.: Howards Waterfall Cave (GDD34), Morrison Cave (GDD86); Floyd Co.: Cave Springs Cave (GFL18); Walker Co.: Bible Springs Cave (GWK74), Cave Spring Cave, Horseshoe Cave (GWK12).

Conservation status: IUCN: Not Evaluated; NatureServe: G5 (SNR in Georgia).

Comments: This species is common and known from caves ranging from Indiana to Virginia and Texas (Schultz, 1970).

\section{Family Ligiidae}

Genus Ligidium

Ligidium elrodii (Packard, 1873) (TX) A Woodlouse

Localities: Dade Co.: Limestone Caverns (GDD140)*; Walker Co.: Ellisons Cave (GWK51), Pigeon Cave (GWK57); Chattooga Co.: Chelsea Gulf Cave (GKH54).

Conservation status: IUCN: Not Evaluated; NatureServe: G4G5 (SNR in Georgia).

Comments: This species is widespread in eastern North America. A subspecies (Ligidium elrodii chattoogaensis) was described from Chelsea Gulf Cave by Schultz (1970).

Family Trichoniscidae

Genus Amerigoniscus

Amerigoniscus curvatus Vandel, 1978 (TB) A Terrestrial Cave Isopod

Localities: Walker Co.: Horseshoe Cave (GWK12).

Conservation status: IUCN: Not Evaluated; NatureServe: G1 (SU in Georgia).

Comments: This troglobite is endemic to Georgia and known only from this site.

\section{Amerigoniscus georgiensis Vandel, 1978 (TB) Georgia Cave Isopod}

Localities: Walker Co.: Pettijohns Cave (GWK29).

Conservation status: IUCN: Not Evaluated; NatureServe: G1 (SU in Georgia).

Comments: This troglobite is endemic to Georgia and known only from this site.

\section{Amerigoniscus proximus Vandel, 1978 (TB) A Terrestrial Cave Isopod}

Localities: Chattooga Co.: Chelsea Gulf Cave (GKH54); Dade Co.: Byers Cave (GDD66).

Conservation status: IUCN: Not Evaluated; NatureServe: G1G2 (SNR in Georgia).

Comments: This troglobite is endemic to Georgia and known only from these sites.

\section{Amerigoniscus sp. (TB) A Terrestrial Cave Isopod}

Localities: Dade Co.: Case Cavern (GDD1), Johnsons Crook Cave $(G D D 17)^{*}$, Sittons Cave (GDD9). Walker Co.: Bible Springs Cave (GWK74), Mountain Cove Farm Cave No. 1 (GWK73).

Comments: These records may represent one of the described Amerigoniscus from Georgia or an undescribed species. 


\section{Genus Miktoniscus}

Miktoniscus sp. (TB/TP) A Terrestrial Isopod

Localities: Bartow Co.: Anthonys Cave (GBT175); Chattooga Co.: Blowing Springs Cave (GKH54), Parkers Cave (GKH119); Dade Co.: Howards Waterfall Cave (GDD34), Sittons Cave (GDD9); Decatur Co.: Climax Cave (GDC36); Grady Co.: Maloys Waterfall Cave (GGR27)*; Randolph Co.: Griers Cave (GRA40); Walker Co.: Horseshoe Cave (GWK12), Pigeon Cave (GWK57), Spooky Cave (GWK494).

Comments: Several of these records are from Reeves et al. (2000), who considered them to be troglobites and possibly an undescribed species.

\section{Superorder Eucarida \\ Order Decapoda \\ Family Cambaridae \\ Genus Cambarus \\ Cambarus bartonii (Fabricius, 1798) (SP) Appalachian Brook Crayfish \\ Localities: Dade Co.: Hurricane Cave (GDD62)*, Twin Snakes Cave (GDD140). \\ Conservation status: IUCN: Least Concern; NatureServe: G5 (S5 in Georgia). \\ Comments: This species is common in caves in the Appalachian Valley and Ridge (Fong et al., 2012).}

\section{Cambarus cryptodytes Hobbs, 1941 (SB) Dougherty Plain Cave Crayfish}

Localities: Baker Co.: Double Springs, USGS Well 10H009, USGS Well 12K014; Calhoun Co.: Chickasawhatchee Swamp WMA Well \#18, Chickasawhatchee Swamp WMA Well \#6, Chickasawhatchee Swamp WMA Well \#7; Calhoun Co.: USGS Well 10K005; Decatur Co.: Climax Cave (GDC36), USGS Well 09F520; Dougherty Co.: Albany Field Well \#8, Chameleon Springs, Radium Springs (GDG39), USGS Well 13L012; Early Co.: USGS Well 08K001; Miller Co.: USGS Well 08G001; Mitchell Co.: USGS Well 10G313; Seminole Co.: USGS Well 06F001.

Conservation status: IUCN: Least Concern; NatureServe: G2G3 (S2 in Georgia); listed as Threatened and considered a Species of Greatest Conservation Need in Georgia.

Comments: Fenolio et al. (2017) reported nine new records from wells in eight counties in southwestern Georgia. This stygobite also occurs into adjacent northwestern Florida (Hobbs et al., 1977; Franz et al., 1994; Fenolio et al., 2017).

Cambarus latimanus (Le Conte, 1856) (TP/TX) Variable Crayfish Localities: Chattooga Co.: Blowing Springs Cave (GKH54); Dade Co.: Byers Cave (GDD66), Hurricane Cave (GDD62); Walker Co.: Mountain Cove Farm Cave No. 1 (GWK73).

Conservation status: IUCN: Least Concern; NatureServe: G5 (S5 in Georgia).

Comments: This is a widely distributed species that is occasionally reported from caves.

Cambarus striatus Hay, 1902 (SP) Ambiguous Crayfish

Localities: Chattooga Co.: Blowing Springs Cave (GKH54); Walker Co.: Bible Springs Cave (GWK74), Horseshoe Cave (GWK12).

Conservation status: IUCN: Least Concern; NatureServe: G5 (S5 in Georgia).

Comments: This is a widely distributed species that is occasionally reported from caves.

Cambarus tenebrosus Hay, 1902 (SP) Cavespring Crayfish

Localities: Dade Co.: Howards Waterfall Cave (GDD34), Hurricane Cave (GDD62).

Conservation status: IUCN: Least Concern; NatureServe: G5 (SNR in Georgia).

Comments: Reeves et al. (2000) reported this stygophile from these two Georgia caves. This species is common in caves in the Interior Low Plateau and occurs in the extreme northwestern part of the state (Niemiller et al., 2013)

Cambarus sp. (SP) A Crayfish

Localities: Dade Co.: Longs Rock Wall Cave (GDD101)*, Sittons Cave (GDD9); Walker Co.: Anderson Spring Cave $(G W K 46)^{\star}$, Ellisons Cave (GWK51), Fricks Cave (GWK14)*, Pigeon Cave (GWK57)*, Roger Branch Cave (GWK204)*.
Comments: The records likely represent one or more of the species listed above.

Class Maxillopoda

Order Cyclopoida

Family Cyclopidae

Genus Acanthocyclops

Acanthocyclops robustus (Sars, 1863) (SP) A Copepod

Localities: Bartow Co.: Anthonys Cave (GBT175).

Comments: This species is common in surface waters but has been collected from caves in Georgia, Indiana, Illinois, Kentucky, and Tennessee (Lewis and Reid, 2007).

Acanthocyclops vernalis (Fischer, 1853) (SP) A Copepod

Localities: Bartow Co.: Kingston Saltpeter Cave (GBT11).

Comments: This species is also known from cave and surface sites in Indiana, Illinois, Kentucky, and Tennessee (Lewis and Reid, 2007).

\section{Genus Eucyclops}

Eucyclops conrowae Reid, 1992 (SX) A Copepod

Localities: Washington Co.: Tennile Caves (GWS20).

Comments: This species is common in surface habitats (Lewis and Reid, 2007).

Eucyclops elegans (Herrick, 1884) (SX) A Copepod

Localities: Bartow Co.: Anthonys Cave (GBT175).

Comments: This primarily surface species has been collected in caves

in Georgia, Indiana, Kentucky, and Tennessee (Lewis and Reid, 2007).

\section{Genus Macrocyclops}

Macrocyclops albidus (Jurine, 1820) (SP) A Copepod

Localities: Bartow Co.: Anthonys Cave (GBT175).

Comments: This species is also known from caves in Illinois, Indiana, Kentucky, and Tennessee (Lewis and Reid, 2007).

Genus Megacyclops

Megacyclops donnaldsoni (Chappuis, 1929) (SB) Donnaldson's Cave Copepod

Localities: Dade Co.: Cemetery Pit (GDD64).

Conservation status: IUCN: Not Evaluated; NatureServe: G3G4 (SNR in Georgia).

Comments: This species was first described from Donnaldson Cave in Lawrence Co., Indiana, but has been collected from caves in Kentucky and Tennessee and is considered a strict troglobiont (Lewis and Reid, 2007).

\section{Order Harpacticoida}

Family Canthocamptidae

Genus Attheyella

Attheyella illinoisensis (Forbes, 1882) (SX/AC) A Copepod

Localities: Walker Co.: Goat Cave (GWK184); Washington Co.: Tennile Caves (GWS20).

Comments: This species is also known from caves in Indiana (Lewis and Reid, 2007).

Attheyella nordenskioldi (Lilljeborg, 1902) (AC) A Copepod

Localities: Dade Co.: Howards Waterfall Cave (GDD34); Walker Co.: Horseshoe Cave (GWK12).

Comments: This species is also known from springs and caves in Illinois and Indiana (Lewis and Reid, 2007).

\section{Attheyella pilosa Chappuis, 1929 (SX) A Copepod}

Localities: Chattooga Co.: Blowing Springs Cave (GKH54)

Comments: This species is also known from springs and caves in Indiana and Kentucky (Lewis and Reid, 2007).

Genus Elaphoidella

Elaphoidella bidens (Schmeil, 1894) (AC) A Copepod

Localities: Washington Co.: Tennile Caves (GWS20).

Class Ostracoda

Order Podocopida

Family Candonidae

Genus Pseudocandona

Pseudocandona sp. (SY) An Ostracod

Localities: Dade Co.: Rusty's Cave (GDD70). 
Comments: Reeves et al. (2000) collected two specimens in the cave stream at Rusty's Cave.

\section{Family Cyprididae}

Genus Potamocypris

Potamocypris sp. (SY) An Ostracod

Localities: Walker Co.: Horseshoe Cave (GWK12).

Comments: This record was reported as Potamocypris cf. fulva by Reeves et al. (2000).

Family Entocytheridae

Genus Uncinocythere

Uncinocythere warreni Hobbs and Walton, 1968 (SB/SY) A Cave

Ostracod

Localities: Decatur Co.: Climax Cave (GDC36).

Conservation status: IUCN: Not Evaluated; NatureServe: G1 (SU in

Georgia).

Comments: This species is endemic to Georgia and known only from Climax Cave where it is a commensal on Cambarus cryptodytes (Hobbs and Walton, 1968; Hart and Hart, 1974).

\section{Subphylum Hexapoda}

Order Collembola

Family Arrhopalitidae

Genus Arrhopalites

Arrhopalites pygmaeus (Wankel, 1860) (TP) A Springtail

Localities: Bartow Co.: Kingston Saltpeter Cave (GBT11).

Comments: This widely distributed springtail is known from caves in several states in the eastern United States (Bellinger et al. 1996-2019; Christiansen, 1960, 1966; Christiansen and Bellinger, 1981; Peck, 1995; Lewis, 2005).

\section{Arrhopalites sp. (TP) A Springtail}

Localities: Walker Co.: Mountain Cove Farm Cave No. 1 (GWK73).

Comments: This may be A. pygmaeus or another species.

\section{Family Entomobryidae}

Genus Lepidocyrtus

Lepidocyrtus sp. (TP) A Slender Springtail

Localities: Bartow Co.: Kingston Saltpeter Cave (GBT11).

Comments: Reeves et al. (2000) reported this springtail from a drip pool. The status of Lepidocyrtus is uncertain and this report may in the future be attributed to a species of Lepidosira (Bellinger et al. 19962019).

\section{Genus Pseudosinella}

Pseudosinella christianseni Salmon, 1964 (TB) Christiansen's Cave Springtail

Localities: Dade Co.: Case Cavern (GDD1), Cemetery Pit (GDD64), Chambliss Cave (GDD321), Ha-Ha Cave (GDD256), Howards Waterfall Cave (GDD34), Sittons Cave (GDD9), Upper Valley Cave (GDD135); Walker Co.: Anderson Spring Cave (GWK46), Ellisons Cave (GWK51), Fricks Cave (GWK14), Goat Cave (GWK184), Nash Waterfall Cave (GWK72), Pettijohns Cave (GWK29), Pigeon Cave (GWK57), Spooky Cave (GWK494).

Conservation status: IUCN: Not Evaluated; NatureServe: G5 (SNR in Georgia).

Comments: This troglobite is eyeless and white without any trace of pigment (Christiansen and Bellinger, 1998). Its range extends across middle Tennessee to Kentucky and into northeastern Alabama and northwestern Georgia.

Pseudosinella georgia Christiansen and Bellinger, 1998 (TP) Georgia Cave Springtail

Localities: Walker Co.: Ellisons Cave (GWK51), Fricks Cave (GWK14), Nash Waterfall Cave (GWK72), Pigeon Cave (GWK57).

Comments: This species is endemic to Georgia and known from only four sites (all caves or pits) but has eyes and scattered pigment across head and body (Christiansen and Bellinger, 1998), so it has been considered a troglophile and not a troglobiont.

Pseudosinella hirsuta (Delamare Deboutteville, 1949) (TB) Hirsute Cave Springtail

Localities: Bartow Co.: Kingston Saltpeter Cave (GBT11); Chattooga Co.: Blowing Springs Cave (GKH54), Chelsea Gulf Cave (GKH54);
Dade Co.: Howards Waterfall Cave (GDD34), Johnsons Crook Cave (GDD17), Morrison Cave (GDD86), Running Water Cave (GDD120), Rusty's Cave (GDD70), Sittons Cave (GDD9); Polk Co.: Deatons Cave (GPO5); Walker Co.: Bible Springs Cave (GWK74), Harrisburg Cave (GWK85), Horseshoe Cave (GWK12), Mountain Cove Farm Cave No. 1 (GWK73), Mountain Cove Farm Cave No. 2 (GWK74), Pettijohns Cave (GWK29).

Conservation status: IUCN: Not Evaluated; NatureServe: G5 (SNR in Georgia).

Comments: This troglobite is usually white and lacks eyes, although some variation is known (Christiansen and Bellinger, 1998). It is widespread in caves across Kentucky, Tennessee, Alabama, and into northwestern Georgia (Christman and Culver, 2001).

Pseudosinella pecki Christiansen and Bellinger, 1980 (TB) Peck's Cave Springtail

Localities: Decatur Co.: Climax Cave (GDC36); Randolph Co.: Griers Cave (GRA40).

Conservation status: IUCN: Not Evaluated; NatureServe: G2G3 (SNR in Georgia).

Comments: This troglobite is eyeless and lacks any trace of pigment. The type locality is in Jackson County, Florida, but it is known from a handful of other caves in Georgia, Alabama, and Tennessee (Christiansen and Bellinger, 1998).

Pseudosinella spinosa (Delamare Deboutteville, 1949) (TB) Spiny Cave Springtail

Localities: Dade Co.: Chapman Cave.

Conservation status: IUCN: Not Evaluated; NatureServe: G5 (SNR in Georgia).

Comments: This troglobite is the largest Nearctic Pseudosinella. It lacks eyes and pigment (Christiansen and Bellinger, 1998). It is known from just one cave in Georgia but ranges across middle Tennessee and northeastern Alabama

\section{Pseudosinella sp. (TB) A Cave Springtail}

Localities: Chattooga Co.: Blowing Springs Cave (GKH54); Dade Co.: Byers Cave (GDD66).

Comments: These record are likely one of the species listed above. The Blowing Springs Cave record was from GBIF (2019).

\section{Family Isotomidae}

\section{Genus Folsomia}

Folsomia candida Willem, 1902 (TP) White Springtail

Localities: Walker Co.: Pettijohns Cave (GWK29).

Comments: This springtail is a widely distributed troglophile.

\section{Family Neelidae}

Genus Neelus

Neelus murinus Folsom, 1896 (TP) A Springtail

Localities: Dade Co.: Howards Waterfall Cave (GDD34).

Comments: Reeves et al. (2000) collected this springtail from organic debris. It is also known form northwestern Europe (Bellinger et al., 1996-2019).

\section{Family Tomoceridae}

\section{Genus Pogonognathellus}

Pogonognathellus bidentatus Folsom, 1913 (TP) Two-toothed Springtail

Localities: Chattooga Co.: Parkers Cave (GKH119); Dade Co.: Byers Cave (GDD66), Case Cavern (GDD1), Morrison Cave (GDD86); Walker Co.: Bible Springs Cave (GWK74), Ellisons Cave (GWK51), Nash Waterfall Cave (GWK72), Pigeon Cave (GWK57).

Comments: This troglophilic springtail is common in caves in the eastern United States (Christiansen, 1964).

\section{Pogonognathellus dubius Christiansen, 1964 (TP) A Springtail}

Localities: Bartow Co.: Kingston Saltpeter Cave (GBT11).

Comments: The taxonomic status of this species is unclear (Felderhoff et al., 2010), but this springtail has been reported from several caves across North America (Christiansen, 1964). 
Pogonognathellus flavescens Tullberg, 1871 (TP) A Springtail Localities: Dade Co.: Johnsons Crook Cave (GDD17); Walker Co.: Cave Springs Cave, Horseshoe Cave (GWK12).

Conservation status: IUCN: Not Evaluated; NatureServe: G5? (SNR in Georgia).

Comments: The taxonomic status of this species is unclear (Felderhoff et al., 2010). It is another widely distributed springtail commonly encountered in caves in North America (Christiansen, 1964).

\section{Family Tullbergiidae}

Genus Tullbergia

Tullbergia iowensis (Mills, 1932) (TP) A Springtail

Localities: Dade Co.: Howards Waterfall Cave (GDD34).

Comments: Reeves et al. (2000) collected this springtail from organic debris.

\section{Order Diplura}

Family Campodeidae

Genus Litocampa

Litocampa cookei (Packard, 1871) (TB) Cooke's Cave Dipluran

Localities: Dade Co.: Howards Waterfall Cave (GDD34)*.

Conservation status: IUCN: Not Evaluated; NatureServe: G5 (SNR in Georgia).

\section{Family Campodeidae}

Localities: Bartow Co.: Chert Chasm (GBT340)*; Chattooga Co.: Blowing Springs Cave (GKH54), Subligna Cave (GKH145)*; Dade Co.: Bible Springs Cave (GWK74), Byers Cave (GDD66), Howards Waterfall Cave (GDD34)*, Johnsons Crook Cave No. 2 (GDD17), Limestone Caverns (GDD140)*, Longs Rock Wall Cave (GDD101)*, Morrison Cave (GDD86), Mountain Cove Farm Cave No. 1 (GWK73); Floyd Co.: Airport Cave (GFL189)*; Walker Co.: Anderson Spring Cave $(\mathrm{GWK} 46)^{*}$, Cave Springs Cave, Ellisons Cave (GWK51), Fingerhole Cave (GWK259)*, Fricks Cave (GWK14), Goat Cave (GWK184)* , Lofton Cave (GWK281)*, Pettijohns Cave (GWK29)*, Pigeon Cave (GWK57)*, Spooky Cave (GWK494).

Comments: Campodeid diplurans are common in Georgia caves but poorly known. These records likely represent multiple undescribed species. Many records are likely in the genus Litocampa.

\section{Family Japygidae}

Localities: Chattooga Co.: Blowing Springs Cave (GKH54); Walker Co.: Mountain Cove Farm Cave No. 1 (GWK73).

Comments: This is a poorly-known group with occasional records from caves in the eastern United States.

\section{Class Insecta}

Order Coleoptera

Family Cantharidae

Genus Cantharis

\section{Cantharis sp. (TX) A Soldier Beetle}

Localities: Chattooga Co.: Parkers Cave (GKH119); Dade Co.: Quarry Cave; Gordon Co.: Rusty Cable Cave (GGO297)*; Walker Co.: Harrisburg Cave (GWK85), Horseshoe Cave (GWK12), Mt. Cove Farm Cave (GWK73), Pettijohns Cave (GWK29).

\section{Family Carabidae}

Genus Anillinus

Anillinus sp. (TB?/ED) A Cave Ground Beetle

Localities: Dade Co.: Hurricane Cave (GDD62), Morrison Cave (GDD86).

Comments: These small, eyeless carabid beetles occur in deep forest leaf litter and in soil. However, troglobites have been reported from several caves in the eastern United States (Sokolov et al., 2004).

\section{Genus Atranus}

Atranus pubescens (Dejean, 1828) (TP) A Ground Beetle

Localities: Dade Co.: Upper Valley Cave (GDD135); Decatur Co. Climax Cave (GDC36); Walker Co.: Bible Springs Cave (GWK74).

\section{Genus Bembidion}

Bembidion lacunarium (Zimmermann, 1869) (TP) A Ground

\section{Beetle}

Localities: Dade Co.: Howards Waterfall Cave (GDD34), Upper Valley Cave (GDD135).
Genus Elaphropus

Elaphropus ferrugineus (Dejean, 1831) (TP) A Ground Beetle

Localities: Decatur Co.: Climax Cave (GDC36).

Elaphropus sp. (TX/AC) A Ground Beetle

Localities: Grady Co.: Glory Hole Cave (GGR56).

Genus Harpalus

Harpalus pensylvanicus (De Geer, 1774) (AC) Pennsylvania Dingy Ground Beetle

Localities: Bartow Co.: Busch Cave (GBT611).

Harpalus sp. (TX/AC) A Ground Beetle

Localities: Dade Co.: Morrison Cave (GDD86); Walker Co.: Bible Springs Cave (GWK74).

Genus Platynus

Platynus parmarginatus Hamilton, 1893 (AC) A Ground Beetle

Localities: Walker Co.: Spooky Cave (GWK494).

Genus Pseudanophthalmus

Pseudanophthalmus digitus Valentine, 1932 (TB) A Cave Beetle

Localities: Dade Co.: Byers Cave (GDD66), Cemetery Pit (GDD64), Johnsons Crook Cave (GDD17).

Conservation status: IUCN: Not Evaluated; NatureServe: G1G2 (SNR in Georgia).

Comments: This troglobite is also known from Hamilton Co., Tennessee and is a member of the hirsutus species group (Barr, 1981, 2004).

\section{Pseudanophthalmus fastigatus Barr, 1981 (TB) Tapered Cave}

Beetle

Localities: Walker Co.: Horseshoe Cave (GWK12).

Conservation status: IUCN: Not Evaluated; NatureServe: G1 (S1? in Georgia).

Comments: This species is only known from the type locality east of Lookout Mountain. It is a member of the engelhardti species group (Barr, 1981, 2004).

\section{Pseudanophthalmus fulleri Valentine, 1932 (TB) Fuller's Cave}

Beetle

Localities: Dade Co.: Boxcar Cave (GDD69)* Byers Cave (GDD66), Caboose Cave (GDD475)*, Cemetery Pit (GDD64), Howards Waterfall Cave (GDD34), Hurricane Cave (GDD62)*, Johnsons Crook Cave (GDD17), Lower Valley Cave (GDD136)*, Morrison Cave (GDD86), Sittons Cave (GDD9), SSS Cave (GDD229)*, Upper Valley Cave (GDD135).

Conservation status: IUCN: Not Evaluated; NatureServe: G2G3 (SNR in Georgia).

Comments: This species is a member of the engelhardti species group (Barr, 1981, 2004).

\section{Pseudanophthalmus georgiae Barr, 1981 (TB) Georgian Cave \\ Beetle}

Localities: Chattooga Co.: Chelsea Gulf Cave (GKH54); Walker Co.: Ellisons Cave (GWK51), Mountain Cove Farm Cave No. 1 (GWK73), Pettijohns Cave (GWK29).

Conservation status: IUCN: Not Evaluated; NatureServe: G1G2 (S1? in Georgia).

Comments: This troglobite is a Georgia endemic and a member of the alabamae species group (Barr, 1981, 2004).

Pseudanophthalmus sp. (TB)

Localities: Chattooga Co.: Parkers Cave (GKH119)*; Walker Co.: Four Kings Cave (GWK77)*.

Comments: The Parkers Cave record was reported as $P$. fulleri, but as all other records for this species are west of Lookout Mountain, this record likely represents $P$. georgiae or $P$. fastigatus instead. The Four Kings Cave record likely represents $P$. georgiae.

Genus Pterostichus

Pterostichus relictus (Newman, 1838) (TX) A Ground Beetle

Localities: Dade Co.: Upper Valley Cave (GDD135). 


\section{Genus Rhadine}

Rhadine caudata LeConte, 1863 (TP) A Ground Beetle

Localities: Dade Co.: Longs Rock Wall Cave (GDD101)*, Rusty's Cave (GDD70)*

Conservation status: IUCN: Not Evaluated; NatureServe: G3 (SNR in Georgia).

Rhadine larvalis LeConte, 1846 (TP) A Ground Beetle

Localities: Dade Co.: Byers Cave (GDD66).

\section{Genus Sphaeroderus}

Sphaeroderus stenostomus (Weber, 1801) (TX) A Ground Beetle

Localities: Dade Co.: Howards Waterfall Cave (GDD34).

Conservation status: IUCN: Not Evaluated; NatureServe: G5 (SNR in Georgia).

\section{Genus Tachys}

Tachys sp. (TX) A Ground Beetle

Localities: Grady Co.: Maloys Waterfall Cave (GGR27).

\section{Family Histeridae}

\section{Genus Margarinotus}

Margarinotus egregius (Casey, 1916) (AC) A Clown Beetle

Localities: Walker Co.: Spooky Cave (GWK494).

Family Leiodidae

Genus Catops

Catops gratiosus (Blanchard, 1915) (TP/TX) Round Fungus Beetle Localities: Chattooga Co.: Parkers Cave (GKH119); Dade Co.: Johnsons Crook Cave (GDD17), Morrison Cave (GDD86), Johnsons Crook Cave No. 2 (GDD19); Walker Co.: Horseshoe Cave (GWK12), Mountain Cove Farm Cave No. 1 (GWK73).

\section{Genus Nemadus}

Nemadus hornii Hatch, 1933 (TP/TX) A Carrion Beetle

Localities: Dade Co.: Johnsons Crook Cave (GDD17), Johnsons Crook Cave No. 2 (GDD19); Decatur Co.: Climax Cave (GDC36); Walker Co.: Rocky Cave (GWK496).

Conservation status: IUCN: Not Evaluated; NatureServe: G1 (SNR in Georgia).

\section{Nemadus sp. (TP/TX) A Carrion Beetle}

Localities: Dade Co.: Morrison Cave (GDD86); Walker Co.: Cave Springs Cave, Horseshoe Cave (GWK12), Mountain Cove Farm Cave No. 1 (GWK73).

\section{Genus Prionochaeta}

\section{Prionochaeta opaca (Say, 1825) (TP/TX) A Carrion Beetle}

Localities: Chattooga Co.: Blowing Springs Cave (GKH54); Walker Co.: Bible Springs Cave (GWK74), Cave Springs Cave, Horseshoe Cave (GWK12), Mountain Cove Farm Cave No. 1 (GWK73).

Conservation status: IUCN: Not Evaluated; NatureServe: G4 (SNR in Georgia).

\section{Genus Ptomaphagus}

Ptomaphagus cavernicola Schwarz, 1898 (TP) A Fungus Beetle Localities: Decatur Co.: Climax Cave (GDC36); Grady Co.: Maloys Waterfall Cave (GGR27).

Conservation status: IUCN: Not Evaluated; NatureServe: G4 (SNR in Georgia).

Comments: This species has well-developed eyes and functional flight wings. It ranges from Mexico to Texas, the Ozarks, and the southeastern United States. It has been collected in forests and caves in southwestern Georgia (Peck, 1973, 1982).

\section{Ptomaphagus fiskei Peck, 1973 (TB) A Cave Fungus Beetle}

Localities: Walker Co.: Anderson Spring Cave (GWK46), Ellisons Cave (GWK51), Fingerhole Cave (GWK259)*, Kinda Pretty Cave (GWK258)*, Missing Evan Well Cave (GWK488)*, Mountain Cove Farm Cave No. 1 (GWK73), Mountain Cove Farm Cave No. 2 (GWK74), Pettijohns Cave (GWK29), Pigeon Cave (GWK57), Spooky Too Cave (GWK496).

Conservation status: IUCN: Not Evaluated; NatureServe: G1G2 (SNR in Georgia).

Comments: This troglobite is endemic to Georgia. It has greatly reduced eyes and lacks flight wings. It is the only troglobitic Ptomaphagus known from east of Lookout Mountain in Georgia and is limited to caves along Lookout Mountain and Pigeon Mountain in Walker County (Peck, 1973; Leray et al., 2019).

Ptomaphagus whiteselli Barr, 1963 (TB) A Cave Fungus Beetle Localities: Dade Co.: Byers Cave (GDD66), Case Cavern (GDD1), Cemetery Pit (GDD64), Hurricane Cave (GDD62), Limestone Caverns (GDD140), Morrison Cave (GDD86), Rusty's Cave (GDD70), Sittons Cave (GDD9).

Conservation status: IUCN: Not Evaluated; NatureServe: G2G3 (SNR in Georgia).

Comments: This species has greatly reduced eyes and lacks flight wings. It is limited to caves in Lookout Valley in Dade County and adjacent DeKalb Co., Alabama (Peck, 1973; Leray et al., 2019).

\section{Ptomaphagus sp. (TB) A Cave Fungus Beetle}

Localities: Dade Co.: Johnsons Crook Cave No. 2 (GDD19), Morrison Cave (GDD86); Walker Co.: Smartt Farm Cave (GWK124)*.

Comments: The records from Dade Co. are likely $P$. whiteselli; the record from Walker Co. is likely $P$. fiskei.

Genus Sciodrepoides

Sciodrepoides terminans (LeConte, 1850) (TX/AC) A Fungus Beetle

Localities: Walker Co.: Cave Springs Cave.

Conservation status: IUCN: Not Evaluated; NatureServe: G5 (SNR in Georgia).

Family Staphylinidae

Genus Atheta

Atheta annexa Casey, 1910 (TP) A Rove Beetle

Localities: Bartow Co.: Yarbrough Cave (GBT30); Dade Co.: Morrison Cave (GDD86); Decatur Co.: Climax Cave (GDC36); Grady Co.: Maloys Waterfall Cave (GGR27); Walker Co.: Chickamagua Cave Spring Cave, Horseshoe Cave (GWK12), Mountain Cove Cave (GDD64).

Conservation status: IUCN: Not Evaluated; NatureServe: G5 (SNR in Georgia)

\section{Atheta klagesi Bernhauer, 1909 (TP) A Rove Beetle}

Localities: Dade Co.: Byers Cave (GDD66), Howards Waterfall Cave (GDD34).

Atheta lucifuga Klimaszewski and Peck, 1986 (TP) Light

Shunning Rove Beetle

Localities: Walker Co.: Mountain Cove Cave (GDD64).

Conservation status: IUCN: Not Evaluated; NatureServe: G4 (SNR in Georgia)

\section{Atheta troglophila Klimaszewski and Peck, 1986 (TP) A Rove} Beetle

Localities: Dade Co.: Byers Cave (GDD66), Howards Waterfall Cave (GDD34); Walker Co.: Mountain Cove Cave (GDD64).

Conservation status: IUCN: Not Evaluated; NatureServe: G4 (SNR in Georgia)

\section{Atheta sp. (TP) A Rove Beetle}

Localities: Chattooga Co.: Blowing Springs Cave (GKH54), Parkers Cave (GKH119); Dade Co.: Byers Cave (GDD66), Johnsons Crook Cave (GDD17), Morrison Cave (GDD86); Walker Co.: Bible Springs Cave (GWK74), Cave Springs Cave, Horseshoe Cave (GWK12), Mountain Cove Farm Cave No. 1 (GWK73), Pettijohns Cave (GWK29).

\section{Genus Batriasymmodes}

Batriasymmodes spelaeus (Park, 1951) (TB) A Cave Ant-loving Beetle

Localities: Chattooga Co.: Blowing Springs Cave (GKH54), Chelsea Gulf Cave (GKH54); Dade Co.: Kirchmeyer Cave (GDD196)*; Walker Co.: Mountain Cove Farm Cave No. 2 (GWK74).

Conservation status: IUCN: Not Evaluated; NatureServe: G3G4 (SNR in Georgia).

Comments: This species is also known from caves in northeastern Alabama and central and eastern Tennessee. Although eyed, it was considered a troglobiont by Park (1960) and others, but a troglophile by Holsinger and Peck (1971). 
Batriasymmodes sp. (TB/TP) An Ant-loving Beetle

Localities: Dade Co.: Howards Waterfall Cave (GDD34).

Genus Batrisodes

Batrisodes lineaticollis (Aubé, 1833) (TP) An Ant-loving Beetle

Localities: Decatur Co.: Climax Cave (GDC36).

Comments: This species is widely distributed in eastern North America.

Batrisodes sp. (TP/TX) An Ant-loving Beetle

Localities: Dade Co.: Howards Waterfall Cave (GDD34)* Limestone Caverns (GDD140); Walker Co.: Pigeon Cave (GWK57).

\section{Genus Creophilus}

Creophilus maxillosus (Linnaeus, 1758) (TP) Hairy Rove Beetle

Localities: Dade Co.: Howards Waterfall Cave (GDD34).

Conservation status: IUCN: Not Evaluated; NatureServe: G5 (SNR in Georgia).

\section{Genus Geodromicus}

Geodromicus brunneus (Say, 1823) (TX/AC) A Rove Beetle

Localities: Walker Co.: Bible Springs Cave (GWK74), Mountain Cove Farm Cave No. 1 (GWK73).

\section{Genus Lesteva}

Lesteva pallipes LeConte, 1863 (TP) A Rove Beetle

Localities: Bartow Co.: Chert Chasm (GBT340); Chattooga Co.: Blowing Springs Cave (GKH54); Dade Co.: Hurricane Cave (GDD62)I Walker Co.: Bible Springs Cave (GWK74), Mountain Cove Farm Cave No. 1 (GWK73), Rocky Cave (GWK496).

\section{Lesteva sp. (TX) A Rove Beetle}

Localities: Dade Co.: Byers Cave (GDD66).

\section{Genus Oxypoda}

Oxypoda sp. (TX/AC) A Rove Beetle

Localities: Bartow Co.: Yarbrough Cave (GBT30); Dade Co.: Byers Cave (GDD66).

\section{Genus Philonthus}

Philonthus cyanipennis (Fabricius, 1792) (AC) A Rove Beetle

Localities: Walker Co.: Pettijohns Cave (GWK29).

Philonthus sp. (AC) A Rove Beetle

Localities: Grady Co.: Maloys Waterfall Cave (GGR27); Walker Co.: Bible Springs Cave (GWK74).

\section{Genus Quedius}

Quedius erythrogaster Mannerheim, 1852 (TP) A Rove Beetle Localities: Dade Co.: Morrison Cave (GDD86); Walker Co.: Harrisburg Cave (GWK85), Hickman Gulf Cave, Pettijohns Cave (GWK29).

Quedius fulgidus (Fabricius, 1793) (TP) A Rove Beetle Localities: Polk Co.: White River Cave (GPO7).

\section{Quedius sp. (TP) A Rove Beetle}

Localities: Dade Co.: Howards Waterfall Cave (GDD34).

\section{Genus Sepedophilus}

Sepedophilus littoreus (Linnaeus, 1758) (TP) A Rove Beetle

Localities: Walker Co.: Horseshoe Cave (GWK12).

\section{Genus Speleochus}

Speleochus sp. (TB) A Cave Rove Beetle

Localities: Dade Co.: Limestone Caverns (GDD140)*; Walker Co.: Pigeon Cave (GWK57).

\section{Genus Subterrochus}

Subterrochus sp. (TB) A Cave Rove Beetle

Localities: Walker Co.: Mountain Cove Farm Cave No. 1 (GWK73).

\section{Genus Tachinus}

Tachinus fimbriatus Gravenhorst, 1802 (TX/AC) A Rove Beetle

Localities: Walker Co.: Pettijohns Cave (GWK29).

\section{Genus Xenota}

Xenota sp. (TP/TX) A Rove Beetle

Localities: Dade Co.: Deans Pit (GDD273), Johnsons Crook Cave (GDD17); Walker Co.: Horseshoe Cave (GWK12), Pettijohns Cave (GWK29).

Family Trogidae

Genus Trox

Trox aequalis Say, 1832 (TX) A Hide Beetle

Localities: Walker Co.: Fricks Cave (GWK14).

\section{Order Diptera}

Family Calliphoridae

Genus Calliphora

Calliphora vicina Robineau-Desvoidy, 1830 (TX) Blue Blow Fly

Localities: Dade Co.: Deans Pit (GDD273), Howards Waterfall Cave (GDD34); Walker Co.: Horseshoe Cave (GWK12).

Calliphora vomitoria (Linnaeus, 1758) (TX) Blue Bottle Fly Localities: Dade Co.: Byers Cave (GDD66), Howards Waterfall Cave (GDD34); Walker Co.: Harrisburg Cave (GWK85).

Genus Lucilia

Lucilia sp. (TX/AC) A Blow Fly

Localities: Dade Co.: Howards Waterfall Cave (GDD34).

Family Cecidomyiidae

Genus Bremia

Bremia sp. (TX/AC) A Gall Midge

Localities: Dade Co.: Sittons Cave (GDD9).

Family Chironomidae

Genus Chironomus

Chironomus decorus Johannsen, 1905 (AC) A Non-biting Midge

Localities: Washington Co.: Tennile Caves (GWS20).

Genus Procladius

Procladius bellus (Loew, 1866) (TX) A Midge

Localities: Bartow Co.: Busch Cave (GBT611).

Genus Tanytarsus

Tanytarsus sp. (TX) A Non-biting Midge

Localities: Bartow Co.: Busch Cave (GBT611).

Comments: This record was identified as Tanytarsus nr. recurvatus by Reeves et al. (2000).

Family Culicidae

Genus Anopheles

Anopheles punctipennis (Say, 1823) (TX) Spot-winged Malaria Mosquito

Localities: Dade Co.: Howards Waterfall Cave (GDD34), Hurricane

Cave (GDD62); Walker Co.: Fricks Cave (GWK14), Horseshoe Cave (GWK12).

Conservation status: IUCN: Not Evaluated; NatureServe: G5 (SNR in Georgia).

Genus Culex

Culex territans Walker, 1856 (TX) Northern Frog-biting Mosquito

Localities: Walker Co.: Horseshoe Cave (GWK12).

Conservation status: IUCN: Not Evaluated; NatureServe: G5 (SNR in Georgia).

Culex sp. (TX) A Mosquito

Localities: Dade Co.: SSS Cave (GDD229)*.

Family Dolichopodidae

Genus Lianculus

Liancalus genualis Loew, 1861 (TX) A Long-legged Fly

Localities: Bartow Co.: Yarbrough Cave (GBT30).

Genus Neurigonella

Neurigonella sombrea (Harmston and Knowlton, 1945) (TX/AC) A Long-legged Fly

Localities: Dade Co.: Upper Valley Cave (GDD135). 
Family Drosophilidae

Genus Drosophila

Drosophila sp. (TX/AC) A Fruit Fly

Localities: Dade Co.: Howards Waterfall Cave (GDD34).

Family Heleomyzidae

Genus Amoebaleria

Amoebaleria defessa (Osten-Sacken, 1877) (TX) A Sun Fly

Localities: Bartow Co.: Busch Cave (GBT611), Kingston Saltpeter Cave (GBT11); Catoosa Co.: Crane Cave (GCZ80)*; Chattooga Co.: Parkers Cave $(\mathrm{GKH} 119)^{*}$, Scoggins II Cave $(\mathrm{GKH} 405)^{*}$; Dade Co.: Byers Cave (GDD66), Caboose Cave (GDD475)*, Cemetery Pit (GDD64), Hooker Cave (GDD90)*, Howards Waterfall Cave (GDD34), Hurricane Cave (GDD62), Johnsons Crook Cave (GDD17)*, Kirchmeyer Cave $(G D D 196)^{*}$, Limestone Caverns (GDD140)*, Longs Rock Wall Cave (GDD101)* $^{*}$, Lower Valley Cave (GDD136*), Morrison Cave (GDD86), Running Water Cave (GDD120), Rusty's Cave (GDD70), Sittons Cave (GDD9), SSS Cave (GDD229)*, Upper Valley Cave (GDD135), Wild Bills Dakota Cave (GDD596)*; Floyd Co.: Airport Cave (GFL189)*, Cave Springs Cave (GFL18)*; Polk Co.: White River Cave (GPO7)* Walker Co.: Anderson Spring Cave (GWK46), Bee Rock Cave (GWK123)*, Ellisons Cave (GWK51), Harrisburg Cave (GWK85), Horseshoe Cave (GWK12), LittleJohn Cave (GWK280)*, Mountain Cove Farm Cave No. 1 (GWK73), Pettijohns Cave (GWK29), Screech Owl Cave (GWK205)*, Smartt Farm Cave (GWK124)*

Comments: This sunfly is common in caves of the eastern United States (e.g., Peck, 1995; Reeves et al., 2000; Lewis, 2005).

\section{Genus Heleomyza}

Heleomyza brachypterna (Loew, 1873) (TX) A Sun Fly

Localities: Walker Co.: Harrisburg Cave (GWK85), Mountain Cove Farm Cave No. 1 (GWK73).

\section{Genus Oecothea}

Oecothea specus (Aldrich, 1897) (TX) A Sun Fly

Localities: Bartow Co.: Busch Cave (GBT611), Kingston Saltpeter Cave (GBT11); Catoosa Co.: Chapmans Cave (GCZ25)*; Chattooga Co.: Parkers Cave (GKH119)*, Scoggins II Cave (GKH405)*; Dade Co.: Hooker Cave (GDD90)*, Howards Waterfall Cave (GDD34)*, Johnsons Crook Cave (GDD17), Limestone Caverns (GDD140)*, Longs Rock Wall Cave (GDD101)*, Sittons Cave (GDD9), SSS Cave (GDD229)*, Wild Bills Dakota Cave (GDD596)*; Gordon Co.: Jack Crider Cave (GGO298**; Polk Co.: White River Cave (GPO7); Walker Co.: Bible Springs Cave (GWK74), Cave Springs Cave, Horseshoe Cave (GWK12), LittleJohn Cave (GWK280)*, Lofton Cave (GWK281)*, Mountain Cove Farm Cave No. 1 (GWK73)*, Mountain Cove Farm Cave No. 2 (GWK74), Smartt Farm Cave (GWK124)*.

Comments: Like Amoebaleria defessa, this species is also common in caves of the eastern United States (e.g., Peck, 1995; Reeves et al., 2000; Lewis, 2005).

Family Muscidae

Genus Chaetogenia

Chaetogenia sp. (TX/AC) A House Fly

Localities: Bartow Co.: Yarbrough Cave (GBT30).

\section{Genus Muscina}

Muscina prolapsa (Harris, 1780) (TX) A House Fly

Localities: Dade Co.: Sittons Cave (GDD9); Walker Co.: Horseshoe Cave (GWK12).

Family Mycetophilidae

Genus Leia

Leia sp. (TP/TX) A Fungus Gnat

Localities: Dade Co.: Byers Cave (GDD66), Howards Waterfall Cave (GDD34).

\section{Genus Rymosa}

Rymosa sp. (TP/TX) A Fungus Gnat

Localities: Dade Co.: Sittons Cave (GDD9).

\section{Family Phoridae}

Genus Megaselia

Megaselia breviterga (Lundback, 1921) (TX) A Scuttle Fly

Localities: Dade Co.: Byers Cave (GDD66), Deans Pit (GDD273), Howards Waterfall Cave (GDD34), Rock Shelter Pit (GDD209); Walker Co.:
Harrisburg Cave (GWK85), Horseshoe Cave (GWK12), Missing Evan Well Cave (GWK488)*, Pettijohns Cave (GWK29).

Comments: This species was collected in large numbers at baited traps near cave entrances in northwestern Georgia (Campbell et al., 2011; Disney and Campbell, 2011). Disney and Campbell (2011) indicate M. spelunciphila is a synonym for M. breviterga.

\section{Megaselia cavernicola (Brues, 1906) (TP) Cave Scuttle Fly}

Localities: Dade Co.: Byers Cave (GDD66), Howards Waterfall Cave (GDD34), Johnsons Crook Cave (GDD17), Johnsons Crook Cave No. 2 (GDD19); Gordon Co.: Rusty Cable Cave (GGO297)*; Walker Co.: Anderson Spring Cave (GWK46), Harrisburg Cave (GWK85), Horseshoe Cave (GWK12), Pettijohns Cave (GWK29).

Comments: This species was collected in large numbers at baited traps in caves in northwestern Georgia (Campbell et al., 2011; Disney and Campbell, 2011). When comparing $M$. breviterga, M. cavernicola, and M. taylori, Disney and Campbell (2011) noted that $M$. cavernicola was more common further from cave entrances than the other two species.

\section{Megaselia taylori Disney, 2010 (TX) A Scuttle Fly}

Localities: Dade Co.: Byers Cave (GDD66), Howards Waterfall Cave (GDD34); Walker Co.: Harrisburg Cave (GWK85), Pettijohns Cave (GWK29).

Comments: This species was collected in large numbers at baited traps near cave entrances in northwestern Georgia (Campbell et al., 2011; Disney and Campbell, 2011).

\section{Megaselia sp. (TP/TX) A Scuttle Fly}

Localities: Bartow Co.: Yarbrough Cave (GBT30); Chattooga Co.: Blowing Springs Cave (GKH54), Parkers Cave (GKH119); Dade Co.: Morrison Cave (GDD86); Polk Co.: White River Cave (GPO7); Walker Co.: Cave Springs Cave, Mountain Cove Farm Cave No. 1 (GWK73).

\section{Genus Puliciphora}

Puliciphora virginiensis Malloch, 1912 (TP) A Scuttle Fly

Localities: Walker Co.: Horseshoe Cave (GWK12).

\section{Family Psychodidae}

Genus Psychoda

Psychoda pusilla Tonnoir, 1922 (TP) A Moth Fly

Localities: Walker Co.: Horseshoe Cave (GWK12).

Psychoda reevesi Quate, 2000 (TP) Reeves' Moth Fly

Localities: Dade Co.: Johnsons Crook Cave No. 2 (GDD19).

\section{Psychoda sp. (TP) A Moth Fly}

Localities: Bartow Co.: Kingston Saltpeter Cave (GBT11); Dade Co.: Byers Cave (GDD66), Howards Waterfall Cave (GDD34); Walker Co.: Harrisburg Cave (GWK85), Pettijohns Cave (GWK29).

\section{Family Sciaridae}

Genus Bradysia

Bradysia forficulata (Bezzi, 1914) (TP/TX) A Fungus Gnat

Localities: Dade Co.: Johnsons Crook Cave (GDD17)*, Johnsons Crook Cave No. 2 (GDD19).

\section{Bradysia sp. (TP/TX) A Fungus Gnat}

Localities: Dade Co.: Howards Waterfall Cave (GDD34); Walker Co.: Harrisburg Cave (GWK85).

\section{Genus Corynoptera}

Corynoptera sp. (TP/TX) A Fungus Gnat

Localities: Chattooga Co.: Parkers Cave (GKH119)*; Dade Co.: Upper Valley Cave (GDD135); Walker Co.: Horseshoe Cave (GWK12).

\section{Genus Lycoriella}

\section{Lycoriella sp. (TP/TX) A Fungus Gnat}

Localities: Bartow Co.: Anthonys Cave (GBT175); Dade Co.: Deans Pit (GDD273), Johnsons Crook Cave No. 2 (GDD19); Walker Co.: Horseshoe Cave (GWK12), Pettijohns Cave (GWK29).

\section{Genus Sciara}

Sciara sp. (TP/TX) A Fungus Gnat

Localities: Bartow Co.: Kingston Saltpeter Cave (GBT11); Dade Co.: Byers Cave (GDD66), Johnsons Crook Cave (GDD17); Polk Co.: White River Cave (GPO7); Walker Co.: Mountain Cove Farm Cave No. 1 (GWK73). 
Family Simuliidae

Genus Prosimulium

Prosimulium saltus Stone and Jamnback, 1955 (TX) A Black Fly

Localities: Dade Co.: Johnsons Crook Cave No. 2 (GDD19).

\section{Genus Simulium}

Simulium parnassum Malloch, 1914 (TX) Dark Black Fly

Localities: Dade Co.: Johnsons Crook Cave No. 2 (GDD19).

\section{Family Sphaeroceridae}

Genus Leptocera

Leptocera caenosa (Rondani, 1880) (TP) A Lesser Dung Fly

Localities: Dade Co.: Howards Waterfall Cave (GDD34)* Johnsons

Crook Cave No. 2 (GDD19); Walker Co.: Fricks Cave (GWK14)*, Pettijohns Cave (GWK29).

\section{Leptocera sp. (TP/TX) A Lesser Dung Fly}

Localities: Chattooga Co.: Blowing Springs Cave (GKH54); Dade Co.: Byers Cave (GDD66), Johnsons Crook Cave (GDD17); Walker Co.: Bible Springs Cave (GWK74), Mountain Cove Farm Cave No. 1 (GWK73).

\section{Genus Spelobia}

Spelobia tenebrarum (Aldrich, 1897) (TB) Cave Dung Fly

Localities: Chattooga Co.: Chelsea Gulf Cave (GKH54); Dade Co.: Howards Waterfall Cave (GDD34), Johnsons Crook Cave (GDD17), Limestone Caverns (GDD140), Rising Fawn Exit Cave (GDD397), SSS Cave (GDD229)* Wild Bills Dakota Cave (GDD596)*; Walker Co.: Horseshoe Cave (GWK12)*, Mountain Cove Farm Cave No. 1 (GWK73), Mountain Cove Farm Cave No. 2 (GWK74)*, Pettijohns Cave (GWK29). Conservation status: IUCN: Not Evaluated; NatureServe: G5 (SNR in Georgia).

Comments: This dung fly is common on scat in caves across the southern Appalachians and Interior Low Plateau. Eyes are present but reduced in size relative to surface species of Spelobia (Marshall and Peck, 1985a, 1985b).

Family Syrphidae

Genus Copestylum

Copestylum vesicularium (Curran, 1947) (TX/AC) Irridescent Bromeliad Fly

Localities: Grady Co.: Maloys Waterfall Cave (GGR27).

\section{Family Tipulidae}

\section{Genus Dolichopeza}

Dolichopeza tridenticulata Alexander, 1931 (TX) A Crane Fly

Localities: Dade Co.: Sittons Cave (GDD9).

Dolichopeza walleyi (Johnson, 1931) (TX) A Crane Fly

Localities: Bartow Co.: Anthonys Cave (GBT175).

Genus Tipula

Tipula abdominalis (Say, 1823) (TX) Giant Crane Fly

Localities: Walker Co.: Ellisons Cave (GWK51).

Family Trichoceridae

Genus Trichocera

Trichocera fattigiana Alexander, 1952 (TX) A Winter Crane Fly

Localities: Dade Co.: Howards Waterfall Cave (GDD34), Hurricane

Cave (GDD62); Walker Co.: Anderson Spring Cave (GWK46).

Trichocera sp. (TX) A Winter Crane Fly

Localities: Walker Co.: Horseshoe Cave (GWK12).

\section{Order Hemiptera}

Family Cicadidae

Genus Magicicada

Magicicada sp. (AC) A Periodical Cicada

Localities: Walker Co.: Horseshoe Cave (GWK12).

Comments: This genus is common in the southeastern USA, where it is edaphic as a nymph; this record represents a surface species.

\section{Family Veliidae}

\section{Genus Microvelia}

Microvelia americana (Uhler, 1884) (AC) A Water Strider

Localities: Dade Co.: Howards Waterfall Cave (GDD34).
Order Hymenoptera

Family Braconidae

Genus Aspilota

Aspilota sp. (TX/AC) A Parasitoid Wasp

Localities: Bartow Co.: Yarbrough Cave (GBT30); Dade Co.: Byers Cave (GDD66), Deans Pit (GDD273), Howards Waterfall Cave (GDD34), Johnsons Crook Cave (GDD17), Rock Shelter Pit (GDD209), Sittons Cave (GDD9), Upper Valley Cave (GDD135); Walker Co.: Horseshoe Cave (GWK12), Mountain Cove Farm Cave No. 1 (GWK73).

Family Formicidae

Genus Myrmecina

Myrmecina americana Emery, 1895 (TX) American Little Ant

Localities: Dade Co.: Johnsons Crook Cave No. 2 (GDD19).

Conservation status: IUCN: Not Evaluated; NatureServe: G5 (SNR in Georgia).

Order Lepidoptera

Family Erebidae

Genus Scoliopteryx

Scoliopteryx libatrix (Linnaeus, 1758) (TX) Herald Moth

Localities: Dade Co.: Howards Waterfall Cave (GDD34), Johnsons Crook Cave (GDD17), Johnsons Crook Cave No. 2 (GDD19); Walker Co.: Anderson Spring Cave (GWK46)*, Horseshoe Cave (GWK12).

Conservation status: IUCN: Not Evaluated; NatureServe: G5 (SNR in

Georgia).

Comments: This moth commonly overwinters in caves in the eastern United States.

Family Noctuidae

Genus Lophoterges

Lophoterges sp. (TX/AC) An Owlet Moth

Localities: Walker Co.: Fricks Cave (GWK14)*.

Order Megaloptera

Family Corydalidae

Genus Corydalus

Corydalus cornutus ((Linnaeus, 1758) (AC) Eastern Dobsonfly

Localities: DeKalb Co.: Nice Gneiss Cave (GDK329)*.

Order Odonata

Family Cordulegastridae

Genus Cordulegaster

Cordulegaster sp. (AC) A Goldenring Dragonfly

Localities: Washington Co.: Tennile Caves (GWS20).

Family Gomphidae

Genus Progomphus

Progomphus obscurus (Rambur, 1842) (AC) Common Sanddragon Localities: Washington Co.: Tennile Caves (GWS20).

Conservation status: IUCN: Not Evaluated; NatureServe: G5 (SNR in Georgia).

\section{Order Orthoptera}

Family Gryllidae

Genus Eunemobius

Eunemobius sp. (TX/AC) A Ground Cricket

Localities: Chattooga Co.: Subligna Cave $(\mathrm{GKH} 145)^{*}$.

Family Rhaphidophoridae

Genus Ceuthophilus

Ceuthophilus ensifer Packer, 1881 (TX) A Camel Cricket

Localities: Dade Co.: Byers Cave (GDD66), Howards Waterfall Cave (GDD34), Johnsons Crook Cave (GDD17), Morrison Cave (GDD86), Morrison Spring Cave (GDD110).

Comments: This camel cricket is a forest species that has been collected in a few caves (Hubbell, 1936; Lewis, 2005). Within Georgia, it is apparently limited to Dade County. 
Ceuthophilus gracilipes (Haldeman, 1850) (TX) Slender-legged Camel Cricket

Localities: Bartow Co.: Chert Chasm (GBT340)*, Davis Farm Cave (GBT222)*, Yarbrough Cave (GBT30); Dade Co.: Boxcar Cave $\left(\right.$ GDD69) $^{*}$, Byers Cave (GDD66), Caboose Cave (GDD475)*, Case Cavern (GDD1), Hooker Cave (GDD90)*, Morrison Cave (GDD86), Morrison Spring Cave (GDD110), Sittons Cave (GDD9), Wild Bills Dakota Cave (GDD596)*; Gordon Co.: Jack Crider Cave (GGO298)*, Roberts Cave (GGO147), Rusty Cable Cave (GGO297)*, Steep Cave (GGO326)*; Walker Co.: Anderson Spring Cave (GWK46), Bible Springs Cave (GWK74), Ellisons Cave (GWK51), Fingerhole Cave (GWK259)*, Fricks Cave (GWK14), LittleJohn Cave $($ GWK280)*, Nash Waterfall Cave (GWK72), Pettijohns Cave (GWK29), Pigeon Cave (GWK57), Rocky Cave (GWK496)*, Smartt Farm Cave (GWK124)*.

Comments: This camel cricket is a forest species that enters caves. It ranges from New York to Florida (Hubbell, 1936).

\section{Ceuthophilus sp. (TX) A Cave Cricket}

Localities: Walker Co.: Mountain Cove Farm Cave No. 2 (GWK74)*.

Comments: This record may be C. ensifer or C. gracilipes.

\section{Genus Diestrammena}

Diestrammena asynamora Adelung, 1902 (TX) Greenhouse Camel Cricket

Localities: Catoosa Co.: Chapmans Cave (GCZ25)*.

Comments: This species was introduced from Asia and recently reported to be common in and around homes in the eastern United States (Epps et al., 2014). This is the first report of the species in a cave in North America. Chapmans Cave is $<100 \mathrm{~m}$ from homes in a housing development, which may explain the presence of these crickets in the cave. Lavoie et al. (2019) reported an unknown cricket species with affinities to Diestrammena from a cave in Pennsylvania, which highlights the need for monitoring of cricket populations to identify the spread of exotic species into cave habitats.

\section{Genus Euhadenoecus}

Euhadenoecus puteanus (Scudder, 1877) (TX) Puteanus Camel Cricket

Localities: Bartow Co.: Davis Farm Cave (GBT222)*; Dade Co.: Boxcar Cave (GDD69)* Byers Cave (GDD66), Caboose Cave (GDD475)*, Case Cavern (GDD1), Hooker Cave (GDD90)*, Howards Waterfall Cave (GDD34), Johnsons Crook Cave (GDD17), Morrison Spring Cave (GDD110), Sittons Cave (GDD9), SSS Cave (GDD229)*, Wild Bills Dakota Cave (GDD596)*; Gordon Co.: Jack Crider Cave (GGO298)*, Roberts Cave (GGO147), Rusty Cable Cave (GGO297)*; Polk Co.: White River Cave (GPO7); Walker Co.: Anderson Spring Cave (GWK46), Bible Springs Cave (GWK74), Cherokee Cave (GWK94), Ellisons Cave (GWK51), Fingerhole Cave (GWK259)*, Fricks Cave (GWK14), Mountain Cove Farm Cave No. 1 (GWK73), Pigeon Cave (GWK57).

Comments: This camel cricket is widespread across the Appalachians and portions of the Interior Low Plateau. It is a surface species that enters caves but generally does not penetrate to deep cave environments (Hubbell and Norton, 1978).

Order Psocodea

Family Liposcelididae

Genus Liposcelis

Liposcelis decolor (Pearman, 1925) (TP) A Booklouse

Localities: Bartow Co.: Kingston Saltpeter Cave (GBT11); Walker Co.: Ellisons Cave (GWK51).

Family Psyllipsocidae

Genus Psyllipsocus

Psyllipsocus ramburii Selys-Longchamps, 1872 (TP) A Barklouse

Localities: Bartow Co.: Yarbrough Cave (GBT30); Walker Co.: Cave Springs Cave, Harrisburg Cave (GWK85).

\section{Order Siphonaptera}

Family Hystrichopsyllidae

Genus Ctenophthalmus

Ctenophthalmus pseudagyrtes Baker, 1904 (SY) A Flea

Localities: Walker Co.: Pettijohns Cave (GWK29).
Order Trichoptera

Family Hydropsychidae

Genus Diplectrona

Diplectrona marianae Reeves, 1999 (TX) A Caddisfly

Localities: Dade Co.: Johnsons Crook Cave No. 2 (GDD19).

Conservation status: IUCN: Not Evaluated; NatureServe: G1 (SNR in Georgia).

Comments: This species was described in Reeves and Paysen (1999); it is endemic to Georgia and known only from the type locality, which was reported with the alternate name "Newsome Gap Spring Cave" (Reeves and Paysen 1999).

\section{Order Zygentoma}

Family Nicoletiidae

Genus Nicoletia

Nicoletia sp. (ED) A Silverfish

Localities: Walker Co.: Horseshoe Cave (GWK12).

Comments: Holsinger and Peck (1971) suggested this may be an undescribed edaphic species.

Subphylum Myriapoda

Class Chilopoda

Order Geophilomorpha

Family Geophilidae

Genus Arenophilus

Arenophilus bipuncticeps Wood, 1862 (TX/AC) Northern Shortclawed Centipede

Localities: Chattooga Co.: Blowing Springs Cave (GKH54).

Order Lithobiomorpha

Family Lithobiidae

Genus Lithobius

Lithobius atkinsoni Bollman, 1887 (TP) A Centipede

Localities: Randolph Co.: Griers Cave (GRA40).

\section{Genus Neolithobius}

Neolithobius voracior Chamberlin, 1912 (TP) A Centipede

Localities: Decatur Co.: Climax Cave (GDC36).

\section{Genus Paitobius}

Paitobius sp. (TX/AC) A Centipede

Localities: Dade Co.: Morrison Spring Cave (GDD110).

Genus Pampibius

Pampibius sp. (TX/AC) A Centipede

Localities: Walker Co.: Cave Springs Cave.

Genus Typhlobius

Typhlobius caecus Bollman, 1888 (TX/AC) A Centipede

Localities: Walker Co.: Fricks Cave (GWK14).

Order Scolopendromorpha

Family Cryptopidae

Genus Scolopocryptops

Scolopocryptops sexspinosus (Say, 1821) (TX/AC) A Centipede

Localities: Dade Co.: Johnsons Crook Cave (GDD17), Morrison Cave (GDD86); Walker Co.: Pettijohns Cave (GWK29).

Class Diplopoda

Order Callipodida

Family Abacionidae

Genus Abacion

Abacion magnum (Loomis, 1943) (TX) A Crested Millipede

Localities: Bartow Co.: Kingston Saltpeter Cave (GBT11); Davis Farm Cave (GBT222)*; Chattooga Co.: Blowing Springs Cave (GKH54) Dade Co.: Byers Cave (GDD66); Polk Co.: White River Cave (GPO7). Conservation status: IUCN: Not Evaluated; NatureServe: G5 (SNR in Georgia)

Comments: The record from Kingston Saltpeter Cave was reported as A. lactarium (Chamberlin, 1946), a species known from the Piedmont and Coastal Plain of the eastern United States, and likely represents a misidentification (Holsinger and Peck, 1971). The record from Davis Farm Cave, also known as Crystal Cave, was also reported as A. lactarium in GBIF (2019). We presume this record to be a misidentification of $A$. magnum. 
Order Chordeumatida

Family Cleidogonidae

Genus Pseudotremia

Pseudotremia aeacus Shear, 1972 (TB) A Cave Millipede

Localities: Dade Co.: Byers Cave (GDD66), Hurricane Cave (GDD62);

Walker Co.: Pigeon Cave (GWK57).

Conservation status: IUCN: Not Evaluated; NatureServe: G1G2 (SNR in Georgia).

Comments: With the exception of the record from Pigeon Cave (in Walker County, east of Lookout Mountain), all known sites are west of Lookout Mountain in Dade County (plus one unpublished record from adjacent DeKalb County, Alabama). The Pigeon Cave record may have been confused with $P$. eburnea, which is known from Pigeon Mountain.

Pseudotremia eburnea Loomis, 1939 (TB) A Cave Millipede Localities: Dade Co.: Byers Cave (GDD66), Case Cavern (GDD1), Cemetery Pit (GDD64), Cricket Cave, Howards Waterfall Cave (GDD34), Hurricane Cave (GDD62), Johnsons Crook Cave (GDD17), SSS Cave (GDD229)*, Upper Valley Cave (GDD135). Walker Co.: Ellisons Cave (GWK51), Fingerhole Cave (GWK259)*, Hickman Gulf Cave, Mountain Cove Farm Cave No. 1 (GWK73), Pettijohns Cave (GWK29), Spooky Cave (GWK494).

Conservation status: IUCN: Not Evaluated; NatureServe: G2G4 (SNR in Georgia).

Comments: Most records are from caves on the escarpments of Lookout Mountain in Walker and Dade counties. Two additional records (Nickajack Cave in Marion Co., Tennessee and Davidson Cave in Marshall Co., Alabama) are further west along the Tennessee River.

Pseudotremia fracta Chamberlin, 1951 (TP) A Millipede

Localities: Walker Co.: Bee Rock Cave (GWK123)*.

Comments: This species is known from surface and cave sites in eastern Tennessee and western North Carolina (Hoffman, 1981). This is the first record of the species in Georgia.

\section{Pseudotremia sp. (TB/TP) A Millipede}

Localities: Dade Co.: Howards Waterfall Cave (GDD34)*, Hooker Cave $(G D D 90)^{*}$, Morrison Cave (GDD86), Morrison Spring Cave (GDD110), Running Water Cave (GDD120), Sittons Cave (GDD9); Walker Co.: Bible Springs Cave (GWK74), Harrisburg Cave (GWK85), Nash Waterfall Cave (GWK72), Pigeon Cave (GWK57)*.

Comments: These records include at least two undescribed species. Specimens from Howards Waterfall Cave are an undescribed species, and those from Hooker Cave represent a second undescribed species (W. Shear, pers. comm.). Buhlmann (2001) mentions other possibly undescribed populations of Pseudotremia.

\section{Family Striariidae}

\section{Genus Striaria}

Striaria sp. (TX) A Millipede

Localities: Chattooga Co.: Parkers Cave (GKH119).

Comments: Troglobitic species in the genus are known but none from Georgia.

\section{Family Trichopetalidae \\ Genus Scoterpes \\ Scoterpes austrinus Loomis, 1946 (TB) A Cave Millipede}

Localities: Bartow Co.: Busch Cave (GBT611); Chattooga Co.: Chelsea Gulf Cave (GKH54); Dade Co.: Cemetery Pit (GDD64), Johnsons Crook Cave (GDD17), Morrison Cave (GDD86), Sittons Cave (GDD9), Upper Valley Cave (GDD135); Walker Co.: Anderson Spring Cave (GWK46), Ellisons Cave (GWK51), Goat Cave (GWK184), Harrisburg Cave (GWK85), Horseshoe Cave (GWK12), Mountain Cove Farm Cave No. 1 (GWK73), Mountain Cove Farm Cave No. 2 (GWK74), Nash Waterfall Cave (GWK72), Pettijohns Cave (GWK29), Spooky Cave (GPO5).

Conservation status: IUCN: Not Evaluated; NatureServe: G3G4 (SNR in Georgia).

Comments: This troglobitic species is known from sites east and west of Lookout Mountain in northwestern Georgia and adjacent regions of northeastern Alabama (Shear, 2010). The record from Busch Cave (Bartow County) likely represents S. nudus, which Shear (2010) raised to species status after the record was reported by Reeves et al. (2000).

Scoterpes nudus Chamberlin, 1946 (TB) A Cave Millipede

Localities: Bartow Co.: Kingston Saltpeter Cave (GBT11); Polk Co.: Deatons Cave (GPO5), White River Cave (GPO7).
Conservation status: IUCN: Not Evaluated; NatureServe: G3G4T1T2 (SNR in Georgia).

Comments: The troglobitic species is endemic to Georgia. It is geographically isolated from all other Scoterpes species and is known from three caves in the Etowah River Valley of Bartow and Polk counties (Shear, 2010). A record of S. austrinus from Busch Cave (Bartow Co.) is likely $S$. nudus.

Scoterpes willreevesi Shear, 2010 (TB) Reeves' Cave Millipede Localities: Dade Co.: Byers Cave (GDD66), Cemetery Pit (GDD64).

Comments: This species is known from a few sites in Dade County, Georgia, and adjacent DeKalb County, Alabama (Shear, 2010).

\section{Scoterpes sp. (TB) A Cave Millipede}

Localities: Chattooga Co.: Scoggins II Cave (GKH405)*; Dade Co.: Case Cavern (GDD1), Howards Waterfall Cave (GDD34), Longs Rock Wall Cave (GDD101)*, "Saw Mill Cave, Rising Fawn"; Walker Co.: Bee Rock Cave (GWK123)*, Fricks Cave (GWK14), Pigeon Cave (GWK57), Smartt Farm Cave (GWK124)*.

Comments: These records represent females or juveniles that could not be identified to species.

\section{Order Julida}

Family Blaniulidae

Genus Blaniulus

Blaniulus guttulatus (Fabricius, 1798) (ED) Spotted Snake Millipede

Localities: Dade Co.: Howards Waterfall Cave (GDD34), Morrison Cave (GDD86).

Conservation status: IUCN: Not Evaluated; NatureServe: G5 (SNR in Georgia).

Comments: This is a soil-inhabiting species that was introduced from Europe. The name of this species is problematic as there is an unresolved homonymy with the species Julus guttulatus Bosc, 1792, which has also been placed in Blaniulus.

\section{Family Zosteractinidae}

Genus Ameractis

Ameractis satis Causey, 1959 (TB) A Cave Millipede

Localities: Dade Co.: Morrison Cave (GDD86).

Conservation status: IUCN: Not Evaluated; NatureServe: G2G4 (SNR in Georgia).

Comments: Holsinger and Peck (1971) reported this troglobiont from Georgia, but no new collections have been reported since then.

\section{Order Platydesmida}

Family Andrognathidae

Genus Andrognathus

Andrognathus corticarius Cope, 1869 (TX) Cope's Noodle Millipede

Localities: Floyd Co.: Cave Springs Cave (GFL18).

Conservation status: IUCN: Not Evaluated; NatureServe: G5 (SNR in Georgia).

\section{Order Polydesmida}

Family Paradoxomatidae

Genus Oxidus

Oxidus gracilis (Koch, 1847) (TP) Greenhouse Millipede

Localities: Bartow Co.: Ladds Lime Cave (GBT384-GBT389); Catoosa

Co.: Chapmans Cave (GCZ25) ${ }^{*}$, Crane Cave (GCZ80)*; Chattooga Co.:

Scoggins II Cave $(\mathrm{GKH} 405)^{*}$, Subligna Cave (GKH145)*; Dade Co.:

Hooker Cave (GDD90)* , Howards Waterfall Cave (GDD34), Limestone

Caverns (GDD140)*, Wild Bills Dakota Cave (GDD596)*; Decatur Co.:

Climax Cave (GDC36); Floyd Co.: Cave Springs Cave (GFL18); Grady Co.: Maloys Waterfall Cave (GGR27); Polk Co.: White River Cave (GPO7)*; Washington Co.: Tennile Caves (GWS20); Walker Co.: LittleJohn Cave (GWK280)*, Mountain Cove Farm Cave No. 2 (GWK74)*, Smartt Farm Cave (GWK124)*.

Conservation status: IUCN: Not Evaluated; NatureServe: G5 (SNR in Georgia).

Comments: This is an exotic species native to Japan and is now commonly encountered in caves. 
Family Polydesmidae

Genus Polydesmus

Polydesmus sp. (TX/AC) A Flatback Millipede

Localities: Dade Co.: Creek Bed Cave.

Family Xystodesmidae

Genus Cherokia

Cherokia georgiana (Bollman, 1889) (AC) Georgia Flat-backed

Millipede

Localities: Walker Co.: Pigeon Cave (GWK57).

Conservation status: IUCN: Not Evaluated; NatureServe: G4 (SNR in

Georgia).

Order Spirostreptida

Family Cambalidae

Genus Cambala

Cambala annulata (Say, 1821) (TP) A Millipede

Localities: Bartow Co.: Anthonys Cave (GBT175); Chattooga Co.:

Scoggins II Cave (GKH405)*, Subligna Cave (GKH145)*; Dade Co.:

Hurricane Cave (GDD62), Longs Rock Wall Cave (GDD101)*, Rusty‘s

Cave (GDD70); Randolph Co.: Griers Cave (GRA40).

Conservation status: IUCN: Not Evaluated; NatureServe: G5 (SNR in

Georgia).

Comments: This species ranges from Pennsylvania and Indiana to

Florida and is commonly encountered in caves (Shelley, 1979).

Cambala hubrichti Hoffman, 1958 (TP) A Millipede

Localities: Catoosa Co.: Chickamauga Cave (GCZ106)*; Grady Co.: Maloys Waterfall Cave (GGR27)*; Walker Co.: Fricks Cave (GWK14), Spooky Cave (GWK494).

Conservation status: IUCN: Not Evaluated; NatureServe: G5 (SNR in Georgia).

Comments: This species is also known from caves in North Carolina (Hertl, 1981). The record from Grady County, Georgia represents a range extension (Shelley, 1979).

\section{Cambala minor Bollman, 1888 (TP) A Millipede}

Localities: Chattooga Co.: Parkers Cave (GKH119); Dade Co.: Morrison Cave (GDD86); Walker Co.: Horseshoe Cave (GWK12), Pettijohns Cave (GWK29).

Conservation status: IUCN: Not Evaluated; NatureServe: G5 (SNR in Georgia).

Comments: This species is known from surface and cave collections across the Tennessee Valley, the Ozarks, and adjacent regions (Shelley, 1979).

Cambala ochra Chamberlin, 1942 (TP) A Millipede

Localities: Bartow Co.: Chert Chasm (GBT340); Walker Co.: Horseshoe Cave (GWK12), Rocky Cave (GWK496).

Comments: This species is known from surface and cave records across the Tennessee River Valley and adjacent regions (Shelley, 1979).

\section{Cambala sp. (TP) A Millipede}

Localities: Catoosa Co.: Chapmans Cave (GCZ25)*; Chattooga Co.: Blowing Springs Cave (GKH54); Dade Co.: Limestone Caverns (GDD140)*; Floyd Co.: Airport Cave (GFL189)*, Cave Springs Cave (GFL18); Walker Co.: Anderson Spring Cave (GWK46)*, Mountain Cove Farm Cave No. 2 (GWK74)*; Polk Co.: Deatons Cave (GPO5), White River Cave (GPO7).

Comments: Most of these records represent juveniles that likely are one of the four species listed above.

\section{Class Symphyla}

Family Scutigerellidae

Genus Scutigerella

Scutigerella sp. (ED) A Garden Centipede

Localities: Dade Co.: Johnsons Crook Cave (GDD17), Sittons Cave (GDD9); Walker Co.: Harrisburg Cave (GWK85).

Comments: These soil-inhabiting arthropods are not well-represented from caves.
Phylum Nematomorpha

Order Gordioidea

Family Gordiidae

Genus Gordius

Gordius sp. (SY) A Horsehair Worm

Localities: Polk Co.: White River Cave (GPO7).

Comments: Horsehair worms are common parasites of cave crickets (Studier et al., 1991).

Phylum Nemertea

Class Enopla

Order Hoplonemertea

Family Tetrastemmatidae

Genus Prostoma

Prostoma sp. (SX/AC?) A Ribbon Worm

Localities: Dade Co.: Howards Waterfall Cave (GDD34).

Comments: The occurrence from Howards Waterfall Cave was reported as Prostoma cf. graecense by Reeves et al. (2000).

Phylum Mollusca

Class Gastropoda

Order Basommatophora

Family Physidae

Genus Physella

Physella gyrina (Say, 1821) (TX) Tadpole Physa

Localities: Washington Co.: Tennile Caves (GWS20)*.

Conservation status: IUCN: Least Concern; NatureServe: G5 (S5 in Georgia).

Order Neotaenioglossa

Family Pleuroceridae

Genus Elimia

Elimia proxima (Say, 1825) (TX) Sprite Elimia

Localities: Washington Co.: Tennile Caves (GWS20)*.

Conservation status: IUCN: Least Concern; NatureServe: G5 (SNR in Georgia).

Order Stylommatophora

Family Gastrodontidae

Genus Gastrodonta

Gastrodonta interna (Say, 1822) (TX) Brown Bellytooth

Localities: Walker Co.: Blowing Springs Cave (GWK41).

Conservation status: IUCN: Not Evaluated; NatureServe: G5 (SNR in Georgia).

Comments: This species is usually found in damp leaf litter and among woody detritus (Hubricht, 1985). It is known from several caves in Tennessee (Lewis, 2005).

\section{Genus Ventridens}

Ventridens gularis (Say, 1822) (TX) Throaty Dome

Localities: Walker Co.: Horseshoe Cave (GWK12).

Conservation status: IUCN: Not Evaluated; NatureServe: G5 (SNR in Georgia).

Comments: This species is found in a variety of habitats, from floodplains and damp hillsides to limestone outcrops. It has been reported from several caves (Lewis, 2005).

Ventridens ligera (Say, 1821) (AC) Globose Dome

Localities: Dade Co.: Kirchmeyer Cave (GDD196)*.

Conservation status: IUCN: Not Evaluated; NatureServe: G5 (SNR in Georgia).

Comments: This species is a habitat generalist, though often found in successional forest habitat and in disturbed areas (Hubricht, 1985; Dourson, 2010).

Ventridens sp. (TX/AC) A Dome Snail

Localities: Walker Co.: Horseshoe Cave (GWK12). 


\section{Genus Zonitoides}

Zonitoides arboreus (Say, 1816) (TP/TX) Quick Gloss

Localities: Dade Co.: Longs Rock Wall Cave (GDD101)* Decatur Co.: Climax Cave (GDC36); Grady Co.: Maloys Waterfall Cave (GGR27); Walker Co.: Blowing Springs Cave (GWK41), Pettijohns Cave (GWK29). Conservation status: IUCN: Not Evaluated; NatureServe: G5 (SNR in Georgia).

Comments: This species is one of the most common and widespread land snails in North America. It is found in a variety of habitats, including several caves (Hubricht, 1964, 1985; Lewis, 2005)

\section{Family Helicodiscidae}

Genus Helicodiscus

Helicodiscus barri Hubricht, 1962 (TB) Raccoon Coil

Localities: Walker Co.: Smartt Farm Cave (GWK124)*; Chattooga Co.: Parkers Cave (GKH119).

Conservation status: IUCN: Least Concern (Gladstone et al., 2018); NatureServe: G3 (SNR in Georgia).

Comments: This troglobiont is often found on woody detritus in damp cave environments (Hubricht, 1962, 1964, 1985; Gladstone et al., 2018). It is distributed throughout the Valley and Ridge and Interior Low Plateau. A single surface locality has been reported, but all other occurrences are from caves. Molecular analyses suggest this species might represent a cryptic species complex (Gladstone et al., 2019).

\section{Helicodiscus inermis Baker, 1929 (TX) Oldfield Coil}

Localities: Polk Co.: White River Cave (GPO7); Walker Co.: Blowing Springs Cave (GWK41).

Comments: This calciphilic species is often found around rocky outcrops and limestone-rich environments (Hubricht, 1985; Dourson, 2010)

\section{Helicodiscus notius Hubricht, 1962 (TX) Tight Coil}

Localities: Grady Co.: Maloys Waterfall Cave (GGR27)*.

Conservation status: IUCN: Not Evaluated; NatureServe: G5Q (SNR in Georgia).

Comments: This calciphilic species is often found around rocky outcrops and limestone-rich environments (Hubricht, 1985; Dourson, 2010). It has been reported from several caves (Hubricht, 1964; Lewis, 2005).

\section{Helicodiscus parallelus (Say, 1817) (TX) Compound Coil}

Localities: Decatur Co.: Climax Cave (GDC36).

Conservation status: IUCN: Not Evaluated; NatureServe: G5 (SNR in Georgia).

Comments: This calciphilic species is often found around rocky outcrops and limestone-rich environments (Hubricht, 1985; Dourson, 2010). It has been reported from several caves (Hubricht, 1964; Lewis, 2005).

\section{Family Oxychilidae \\ Genus Glyphyalinia}

Glyphyalinia cryptomphala (Clapp, 1915) (TX) Thin Glyph

Localities: Chattooga Co.: Parkers Cave (GKH119)*; Dade Co.: Upper Valley Cave (GDD135).

Conservation status: IUCN: Not Evaluated; NatureServe: G5 (SNR in Georgia).

Comments: This common forest snail is often found in damp leaf litter or along weedy forests (Hubricht, 1985). It is associated with limestone-rich environments (Dourson, 2010).

\section{Glyphyalinia indentata (Say, 1823) (TX) Carved Glyph}

Localities: Walker Co.: Harrisburg Cave (GWK85).

Conservation status: IUCN: Not Evaluated; NatureServe: G5 (SNR in Georgia)

Comments: This common forest snail is often found in damp leaf litter or along weedy forests (Hubricht, 1985). It is associated with limestone-rich environments (Dourson, 2010) and known from several caves (Lewis, 2005).

Glyphyalinia praecox (Baker, 1930) (TX) Brilliant Glyph

Localities: Bartow Co.: Anthonys Cave (GBT175).

Conservation status: IUCN: Not Evaluated; NatureServe: G4 (SNR in Georgia)
Comments: This common forest snail is often found in damp leaf litter or along weedy forests (Hubricht, 1985). It is associated with limestone-rich environments (Dourson, 2010) and known from several caves (Lewis, 2005).

\section{Glyphyalinia rhoadsi (Pilsbry, 1899) (TX) Sculpted Glyph}

Localities: Washington Co.: Tennile Caves (GWS20).

Conservation status: IUCN: Not Evaluated; NatureServe: G5 (SNR in Georgia).

Comments: This common forest snail is often found in damp leaf litter or along weedy forests (Hubricht, 1985). It is associated with limestone-rich environments (Dourson, 2010) and known from several caves (Lewis, 2005).

\section{Glyphyalinia sculptilis (Bland, 1858) (TX) Suborb Glyph}

Localities: Bartow Co.: Busch Cave (GBT611); Chattooga Co.: Parkers Cave (GKH119)*; Walker Co.: Bible Springs Cave (GWK74), Rocky Cave (GWK496), Spooky Cave (GWK494).

Conservation status: IUCN: Not Evaluated; NatureServe: G4 (SNR in Georgia).

Comments: This common forest snail is often found in damp leaf litter or along weedy forests (Hubricht, 1985). It is associated with limestone-rich environments (Dourson, 2010) and known from several caves (Lewis, 2005).

\section{Glyphyalinia specus Hubricht, 1965 (TB) Hollow Glyph}

Localities: Chattooga Co.: Parkers Cave (GKH119); Dade Co.: Morrison Cave (GDD86); Walker Co.: Cave Springs Cave, Cherokee Cave (GWK94), Mount Cove Farm Cave, Pettijohns Cave (GWK29).

Conservation status: IUCN: Least Concern (Gladstone et al. 2018); NatureServe: G3 (SNR in Georgia).

Comments: This is a wide-ranging troglobiont found in dry leaf litter and on cave walls. Its distribution is suggestive of greater occurrence throughout Valley and Ridge (Gladstone et al., 2018).

\section{Glyphyalinia wheatleyi (Bland, 1883) (TP/TX) Bright Glyph}

Localities: Floyd Co.: Cave Springs Cave (GFL18)*; Grady Co.: Maloys Waterfall Cave (GGR27)*.

Conservation status: IUCN: Not Evaluated; NatureServe: G5 (SNR in Georgia).

Comments: This common forest snail is often found in damp leaf litter or along weedy forests (Hubricht, 1985). It is associated with limestone-rich environments (Dourson, 2010) and known from several caves (Lewis, 2005).

\section{Family Philomycidae}

Genus Pallifera

Pallifera sp. (TX/AC) A Mantleslug

Localities: Dade Co.: Johnsons Crook Cave (GDD17)*.

\section{Family Polygyridae}

Genus Inflectarius

Inflectarius rugeli (Shuttleworth, 1852) (TX) Deep-tooth Shagreen

Localities: Chattooga Co.: Parkers Cave (GKH119)*.

Conservation status: IUCN: Not Evaluated; NatureServe: G5 (SNR in Georgia).

Comments: This species is primarily found in leaf litter, under logs, or in shaded mesic forest habitat, but can also be found in caves (Niemiller et al., unpublished).

\section{Genus Mesodon}

Mesodon sp. (TX/AC) A Globe Snail

Localities: Walker Co.: Anderson Spring Cave (GWK46).

Comments: Most Mesodon species can be found in forest habitats, under logs or in dense leaf litter. Some species (e.g., M. appressus, $M$. edentatus, $M$. sargentianus) are considered calciphiles, and are common near cave entrances (Hubricht, 1985; Niemiller et al., unpublished).

\section{Genus Patera}

Patera appressa (Say, 1821) (TP/TX) Flat Bladetooth

Localities: Dade Co.: Hooker Cave (GDD90**.

Conservation status: IUCN: Not Evaluated; NatureServe: G5 (SNR in Georgia). 
Comments: This species is associated with rocky outcrops, forest ravines, disturbed habitats along roadsides, and limestone-rich environments. It is a common constituent of cave environments, though not limited to subterranean habitat (Hubricht, 1964, 1985; Lewis, 2005; Dourson, 2010).

Patera perigrapta (Pilsbry, 1894) (TP/TX) Engraved Bladetooth Localities: Chattooga Co.: Parkers Cave (GKH119); Dade Co.: Byers Cave (GDD66).

Conservation status: IUCN: Not Evaluated; NatureServe: G5 (SNR in Georgia).

Comments: This species is associated with rocky outcrops, forest ravines, disturbed habitats along roadsides, and limestone-rich environments. It also is a common constituent of cave environments, though not limited to subterranean habitat (Hubricht, 1964, 1985; Lewis, 2005; Dourson, 2010).

\section{Genus Triodopsis}

\section{Triodopsis sp. (TX/AC) A Threetooth Snail}

Localities: Dade Co.: Wild Bills Dakota Cave (GDD596)*.

Comments: Triodopsis snails occupy a diverse array of habitats, including mesic forest leaf litter, rock outcrops, and urban areas (Hubricht, 1985). This genus has also been reported from several caves (Niemiller et al., unpublished).

\section{Family Pristilomatidae}

\section{Genus Hawaiia}

Hawaiia minuscula (Binney, 1841) (TX) Minute Gem

Localities: Dade Co.: Howards Waterfall Cave (GDD34).

Conservation status: IUCN: Not Evaluated; NatureServe: G5 (SNR in Georgia).

Comments: This species is a habitat generalist, though often found in disturbed habitats, such as greenhouses and gardens (Hubricht, 1985; Dourson, 2010). It has been reported from several caves (Lewis, 2005; Niemiller et al., unpublished)

Family Strobilopsidae

Genus Strobilops

Strobilops texasianus Pilsbry and Ferriss, 1906 (AC) Southern Pinecone

Localities: Decatur Co.: Climax Cave (GDC36)*

Conservation status: IUCN: Not Evaluated; NatureServe: G5 (SNR in Georgia).

Comments: This species is associated with leaf litter and woody detritus forested habitat (Hubricht, 1985). This is the first record from a cave.

Phylum Platyhelminthes

Class Trepaxonemata

Order Neoophora

Family Kenkiidae

Genus Sphalloplana

Sphalloplana georgiana Hyman, 1954 (SB) Georgia Cave Planarian

Localities: Dade Co.: Howards Waterfall Cave (GDD34).

Conservation status: IUCN: Not Evaluated; NatureServe: G1 (SNR in Georgia).

Comments: This species is known only from the type locality at Howards Waterfall Cave (Hyman, 1954; Kenk, 1977)

\section{Sphalloplana sp. (SB) A Cave Planarian}

Localities: Dade Co.: Hurricane Cave (GDD62); Walker Co.: Anderson Spring Cave (GWK46), Pettijohns Cave (GWK29).

Comments: These records may represent other sites for $S$. georgiana or possibly undescribed species.

\section{Phylum Chordata}

Class Actinopterygii

Order Percopsiformes

Family Amblyopsidae

Genus Typhlichthys

Typhlichthys subterraneus Girard, 1859 (SB) Southern Cavefish

Localities: Catoosa Co.: Crane Cave (GCZ80); Dade Co.: Case Cavern (GDD1), Limestone Caverns (GDD140), Longs Rock Wall Cave (GDD101), Sittons Cave (GDD9).
Conservation status: IUCN: Vulnerable; NatureServe: G4 (S1 in Georgia); listed as Endangered and considered a Species of Greatest Conservation Need in Georgia.

Comments: The record from Crane Cave is the first occurrence of this species from the Appalachians karst region (Niemiller et al., 2016). Typhlichthys subterraneus is a cryptic species complex (Niemiller et al., 2012), and populations from Georgia along with a few populations in Marion Co., Tennessee, are likely a distinct species.

\section{Order Scorpaeniformes}

Family Cottidae

Genus Cottus

Cottus bairdii Girard, 1850 (SP) Mottled Sculpin

Localities: Walker Co.: Fricks Cave (GWK14).

Conservation status: IUCN: Least Concern; NatureServe: G5 (S4 in Georgia).

Comments: This is species is thought to be common in caves (Dearolf, 1956; Poly, 2001), and cave records exists from the TAG region (Buhlmann, 2001; Huntsman et al., 2011; Venarsky et al., 2012). Some records of $C$. carolinae may actually represent this species, as both species are very similar morphologically.

\section{Cottus carolinae (Gill, 1861) (SP) Banded Sculpin}

Localities: Dade Co.: Longs Rock Wall Cave (GDD101)*; Walker Co.: Fricks Cave (GWK14)*, Mountain Cove Farm Cave No. 2 (GWK74), Roger Branch Cave (GWK204)*.

Conservation status: IUCN: Least Concern; NatureServe: G5 (S4 in Georgia).

Comments: This species is the most commonly reported fish in caves of the Interior Plateau and Appalachians karst regions (e.g., Cope and Packard, 1881; Dearolf, 1956; Poly and Boucher, 1996; Niemiller et al., 2006, 2016). Several populations are thought to live year-round in caves, with some exhibiting some degree of troglomorphy (Espinasa and Jeffery, 2003; Espinasa et al., 2013).

Cottus sp. (SP) A Sculpin

Localities: Catoosa Co.: Crane Cave (GCZ80)*; Walker Co.: Horseshoe Cave (GWK12)*.

Comments: These records may be $C$. bairdii or $C$. carolinae.

\section{Order Siluriformes}

Family Ictaluridae

Genus Ameiurus

Ameiurus nebulosus (Lesueur, 1819) (SX/AC) Brown Bullhead

Localities: Walker Co.: Horseshoe Cave (GWK12).

Conservation status: IUCN: Least Concern; NatureServe: G5 (S5 in Georgia).

Comments: This species has been reported previously from caves in Florida and West Virginia (Franz et al., 1994; Hale and Streever, 1994; Pruitt, 1995; Poly and Boucher, 1996; Poly, 2001).

\section{Class Amphibia \\ Order Anura \\ Family Bufonidae \\ Genus Anaxyrus \\ Anaxyrus fowleri (Hinckley, 1882) (AC) Fowler's Toad}

Localities: Dade Co.: Case Caverns (GDD1)*

Conservation status: IUCN: Least Concern; NatureServe: G5 (S5 in Georgia)

Comments: This toad has been reported infrequently from caves in eastern Tennessee (Dodd et al., 2001; Niemiller et al., 2016).

\section{Anaxyrus terrestris (Bonnaterre, 1789) (AC) Southern Toad}

Localities: Burke Co.: Utleys Cave*.

Conservation status: IUCN: Least Concern; NatureServe: G5 (S5 in Georgia)

Comments: Pleistocene remains of this species have been found in a cave in Citrus Co., Florida (Holman, 1958). 
Family Hylidae

Genus Hyla

Hyla chrysoscelis Cope, 1880 (TX/AC) Cope's Gray Treefrog

Localities: Walker Co.: Pettijohns Cave (GWK29)*.

Conservation status: IUCN: Least Concern; NatureServe: G5 (S5 in Georgia).

Comments: This treefrog may use caves for shelter during periods of drought, although most records are thought to be accidental occurrences. It has been reported from a few caves in Alabama and Tennessee (Lewis, 2005; Godwin, 2008; Niemiller and Miller, 2009).

Hyla gratiosa LeConte, 1856 (AC) Barking Treefrog

Localities: Walker Co.: Drag Fold Cave (GWK79)*.

Conservation status: IUCN: Least Concern; NatureServe: G5 (S5 in Georgia).

\section{Genus Pseudacris}

Pseudacris crucifer (Wied-Neuwied, 1838) (TX/AC) Spring Peeper

Localities: Dade Co.: Boxcar Cave (GDD69)*; Walker Co.: Pettijohn Cave (GWK29)*, Screech Owl Cave (GWK205)*.

Conservation status: IUCN: Least Concern; NatureServe: G5 (S5 in Georgia).

Comments: This frog has been reported infrequently from caves (Black, 1971; Prather and Briggler, 2001; Godwin, 2008; Niemiller and Miller, 2009; Niemiller et al., 2016). It may seek refuge in caves during prolonged drought (Prather and Briggler, 2001).

\section{Pseudacris feriarum (Baird, 1854) (AC) Upland Chorus Frog}

Localities: Grady Co.: Waterfall Cave (GGR27)*.

Conservation status: IUCN: Least Concern; NatureServe: G5 (S5 in Georgia).

Comments: This frog has been reported infrequently from caves (Black, 1971; Osbourn, 2005; Godwin, 2008; Niemiller and Miller, 2009; Niemiller et al., 2016).

\section{Family Ranidae \\ Genus Rana}

Rana catesbeiana Shaw, 1802 (TX) American Bullfrog

Localities: Dade Co.: Boxcar Cave (GDD69)*, Rusty's Cave (GDD70)* Walker Co.: Anderson Spring Cave (GWK46)* ${ }^{*}$ Pettijohns Cave (GWK29)*; Washington Co.: Tennile Caves (GWS20)*.

Conservation status: IUCN: Least Concern; NatureServe: G5 (S5 in Georgia).

Comments: This species is occasionally reported from caves with substantial aquatic habitat, particularly near entrances and the twilight zone (Barr, 1953; Niemiller and Miller, 2009; Niemiller et al., 2016).

\section{Rana clamitans Latreille, 1801 (TX) Green Frog}

Localities: Dade Co.: Longs Rock Wall Cave (GDD101)*; Decatur Co.: Climax Cave (GDC36); Grady Co.: Waterfall Cave (GGR27)*; Walker Co.: Anderson Spring Cave (GWK46), Ellisons Cave (GWK51), Nash Waterfall Cave (GWK72), Pettijohns Cave (GWK29), Screech Owl Cave (GWK205)*; Washington Co.: Tennile Caves (GWS20)*.

Conservation status: IUCN: Least Concern; NatureServe: G5 (S5 in Georgia).

Comments: This species is occasionally reported from caves (Barr 1953; Buhlmann, 2001; Dodd et al., 2001; Camp and Jensen, 2007; Niemiller and Miller, 2009; Niemiller et al., 2016).

\section{Rana palustris (LeConte, 1825) (TX) Pickerel Frog}

Localities: Dade Co.: Hurricane Cave (GDD62)* Longs Rock Wall Cave (GDD101)*, Sittons Cave (GDD9), Trenton Waterfall Cave; Walker Co.: Anderson Spring Cave (GWK46), Ellisons Cave (GWK51), Nash Waterfall Cave (GWK72), Pettijohns Cave (GWK29)*, Pigeon Cave (GWK57), Roger Branch Cave (GWK204)*, Screech Owl Cave (GWK205)*.

Conservation status: IUCN: Least Concern; NatureServe: G5 (S4 in Georgia).

Comments: This species is regularly reported from caves near entrances and in the twilight zone (Cliburn and Middleton, 1983; Buhlmann, 2001; Camp and Jensen, 2007; Niemiller and Miller, 2009; Niemiller et al., 2016). The record for "Trenton Waterfall Cave" likely represents Howards Waterfall Cave.

Rana sphenocephala Cope, 1886 (TX/AC) Southern Leopard Frog Localities: Grady Co.: Maloys Waterfall Cave (GGR27)*.
Conservation status: IUCN: Least Concern; NatureServe: G5 (S5 in Georgia).

Comments: Unlike other ranid frogs, this species is encountered infrequently in caves, but cave records exist from Tennessee (Lewis, 2005; Niemiller and Miller, 2009).

\section{Order Caudata}

Family Ambystomatidae

Genus Ambystoma

Ambystoma tigrinum (Green, 1825) (AC) Eastern Tiger Salamander

Localities: Walker Co.: Drag Fold Cave (GWK79)*.

Conservation status: IUCN: Least Concern; NatureServe: G5 (S3S4 in Georgia); considered a Species of Greatest Conservation Need in Georgia.

Comments: Although this mole salamander spends much of its life underground in burrows, it is not associated with caves and karst.

\section{Family Plethodontidae}

Genus Aneides

Aneides aeneus (Cope and Packard, 1881) (TX) Green Salamander Localities: Dade Co.: Byers Cave (GDD66)*, Case Caverns (GDD1)*, Howards Waterfall Cave (GDD34) ${ }^{*}$, Sittons Cave (GDD9)*; Walker Co.: Fricks Cave (GWK14), Lula Falls Cave $(G W K 617)^{*}$, Lula Falls Talus Cave $^{*}$, Nash Waterfall Cave (GWK72).

Conservation status: IUCN: Near Threatened; NatureServe: G3G4 (S3 in Georgia); listed as Rare and considered a Species of Greatest Conservation Need in Georgia.

Comments: This species is occasionally reported around entrances of caves along the escarpments of the Cumberland Plateau, including Lookout Mountain and Pigeon Mountain. The type locality is "near the mouth" of Nickajack Cave in Marion Co., Tennessee.

\section{Genus Desmognathus}

Desmognathus conanti Rossman, 1958 (AC) Spotted Dusky Salamander

Localities: Dade Co.: Hurricane Cave (GDD62)*; Walker Co.: Anderson Spring Cave (GWK46), Ellisons Cave (GWK51), Mountain Cove Farm Cave No. 2 (GWK74), Nash Waterfall Cave (GWK72), Pettijohns Cave (GWK29), Pigeon Cave (GWK57); Washington Co.: Tennile Caves $($ GWS20)*.

Conservation status: IUCN: Least Concern; NatureServe: G5 (S5 in Georgia).

Comments: This species has been reported infrequently in and around entrances of spring entrances and is rarely observed in the dark zone (Himes et al., 2004; Niemiller and Miller, 2009; Niemiller et al., 2016).

Desmognathus ocoee Nicholls, 1949 (AC) Ocoee Salamander Localities: Habersham Co.: La Guarida del Diablo*.

Conservation status: IUCN: Least Concern; NatureServe: G5 (S5 in Georgia).

\section{Genus Eurycea}

\section{Eurycea cirrigera (Gre0en, 1831) (TX) Southern Two-lined} Salamander

Localities: Decatur Co.: Climax Cave (GDC36); Polk Co.: White River Cave (GPO7)*; Walker Co.: Anderson Spring Cave (GWK46), Nash Waterfall Cave (GWK72)*, Pigeon Cave (GWK57); Washington Co.: Tennile Caves (GWS20).

Conservation status: IUCN: Least Concern; NatureServe: G5 (S5 in Georgia).

Comments: This species has been reported infrequently from caves (Himes et al., 2004; Lewis, 2005; Camp and Jensen, 2007; Niemiller and Miller, 2009; Niemiller et al., 2016), although a population from Cannon County, Tennessee, has been documented breeding in a cave (Niemiller and Miller, 2007).

\section{Eurycea guttolineata (Holbrook, 1838) (TX) Three-lined}

\section{Salamander}

Localities: DeKalb Co.: Nice Gneiss Cave (GDK329)*; Washington Co.: Tennile Caves (GWS20)*

Conservation status: IUCN: Least Concern; NatureServe: G5 (S4S5 in Georgia).

Comments: This species also has been reported from caves in Alabama and Mississippi (Cooper and Cooper, 1968; Himes et al., 2004). 


\section{Eurycea longicauda (Green, 1818) (TP/TX) Long-tailed}

\section{Salamander}

Localities: Chattooga Co.: Scoggins II Cave (GKH405)*, Subligna Cave $(\mathrm{GKH} 145)^{*}$; Dade Co.: Hurricane Cave $(\mathrm{GDD} 62)^{*}$, Longs Creekside Cave (GDD45)*, Lookout Mountain Spring Cave*, Sittons Cave (GDD9); Walker Co.: Anderson Spring Cave (GWK46), Bible Springs Cave (GWK74)*, Fricks Cave (GWK14), Pettijohns Cave (GWK29), Pigeon Cave (GWK57), "small cave in rock quarry along Georgia Highway 136; 1.65 Highway miles West of Cooper Heights."

Conservation status: IUCN: Least Concern; NatureServe: G5 (S4 in Georgia).

Comments: This species is regularly observed in caves in the Appalachians and Interior Plateau karst regions (Buhlmann, 2001; Dodd et al., 2001; Lewis, 2005; Osbourn, 2005; Taylor and Mays, 2006; Camp and Jensen, 2007; Niemiller and Miller, 2009; Niemiller et al., 2016), although not as frequently as $E$. lucifuga.

\section{Eurycea lucifuga Rafinesque, 1822 (TP) Cave Salamander}

Localities: Bartow Co.: Anthonys Cave (GBT175)* ${ }^{*}$ Chert Chasm (GBT340)*; Catoosa Co.: Chapmans Cave (GCZ25)*, Crane Cave (GCZ80)*; Chattooga Co.: Blowing Spring Cave (GKH54)* Parkers Cave (GKH119)*, Scoggins II Cave (GKH405)*; Dade Co.: Boxcar Cave (GDD69) $^{*}$, Caboose Cave (GDD475)*, Case Cavern (GDD1), Cemetery Pit (GDD64)*, Chambliss Cave (GDD321), Hooker Cave (GDD90)*, Jeff's Hole Cave (GDD400) ${ }^{*}$, Johnsons Crook Cave (GDD17) ${ }^{*}$, Limestone Caverns (GDD140)*, Longs Rock Wall Cave (GDD101)*, Lower Valley Cave (GDD136)*, Morrison Cave (GDD86)*, Sittons Cave (GDD9), SSS Cave (GDD229)*, Trenton caves, Upper Valley Cave

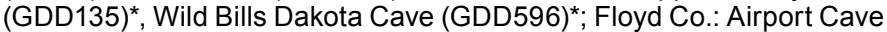
$($ GFL189)*; Gordon Co.: caves near junction of Hwy.411 and Hwy.156 7.0 mi. N of Fairmount ${ }^{*}$, Ford Roberts Cave (GGO147)*; Murray Co.: Fincher Bluff Cave (GMA291)*; Polk Co.: Wise Cave (GPO6)*; Walker Co.: Anderson Spring Cave (GWK46), Bee Rock Cave (GWK123)*, Bible Spring Cave (GWK74)*, Cave Spring Cave*, Ellisons Cave (GWK51), Fingerhole Cave (GWK259)*, Goat Cave (GWK184)*, Harrisburg Cave (GWK85), Horseshoe Cave (GWK12)*, Kinda Pretty Cave $(G W K 258)^{*}$, LittleJohn Cave (GWK280)*, Missing Evan Well Cave $(G W K 488)^{*}$, Mouldy Bat Pit (GWK257)*, Mountain Cove Farm Cave No. 1 (GWK73), Mountain Cove Farm Cave No. 2 (GWK74), Nash Waterfall Cave (GWK72), Pettijohns Cave (GWK29), Pigeon Cave (GWK57), Roger Branch Cave (GWK204)*, Screech Owl Cave (GWK205), Smartt Farm Cave (GWK124)*, Spooky Cave (GWK494)*.

Conservation status: IUCN: Least Concern; NatureServe: G5 (S4 in Georgia).

Comments: This is the most commonly observed salamander in caves in the Appalachians and Interior Plateau karst regions (Hutchinson, 1966; Buhlmann, 2001; Lewis, 2005; Niemiller and Miller, 2009; Camp and Jensen, 2015; Niemiller et al., 2016)

\section{Eurycea wallacei (Carr, 1939) (SB) Georgia Blind Salamander}

Localities: Decatur Co.: Climax Cave (GDC36); Dougherty Co.: Deep well in Albany, Radium Springs (GDG39).

Conservation status: IUCN: Vulnerable; NatureServe: G2 (S1 in Georgia); listed as Threatened and considered a Species of Greatest Conservation Need in Georgia.

Comments: The type locality for this neotenic stygobite is a well near Albany in Dougherty County. It is found in subterranean waters of the Upper Floridan Aquifer in the Dougherty Plain of southeastern Georgia and adjacent northwestern Florida. Eurycea wallacei has been reported from seven sites, but only confirmed from Climax Cave in Decatur County and Radium Springs along the Flint River in Dougherty County (Means, 2005; Fenolio et al., 2013). There is an unconfirmed report from a spring cave in Baker County (Ben Martinez, pers. comm.).

\section{Genus Gyrinophilus}

Gyrinophilus palleucus McCrady, 1954 (SB) Tennessee Cave Salamander

Localities: Walker Co.: Fricks Cave (GWK14), Harrisburg Cave (GWK85).

Conservation status: IUCN: Vulnerable; NatureServe: G2G3 (S1 in Georgia); listed as Threatened and considered a Species of Greatest Conservation Need in Georgia.

Comments: Although wide-ranging throughout south-central Tennessee and northern Alabama (Godwin, 2000; Miller and Niemiller, 2008,
2012), this neotenic stygobite is known from only two caves in Georgia (Buhlmann, 2001; Godwin, 2008; Miller and Niemiller, 2012).

\section{Gyrinophilus porphyriticus (Green, 1827) (TP) Spring Salaman-} der

Localities: Dade Co.: Boxcar Cave (GDD69)*, Byers Cave (GDD66), Howards Waterfall Cave (GDD34)*, Hurricane Cave (GDD62)*, Johnsons Crook Cave (GDD17), Limestone Caverns (GDD140)*, Longs Rock Wall Cave (GDD101)*, Sittons Cave (GDD9), SSS Cave (GDD229)* Wild Bills Dakota Cave (GDD596)*; Walker Co.: Anderson Spring Cave (GWK46), Ellisons Cave (GWK51), Gila Monster Cave (GWK379) $^{*}$, Harrisburg Cave (GWK85), Mountain Cove Farm Cave No. 1 (GWK73), Mountain Cove Farm Cave No. 2 (GWK74), Nash Waterfall Cave (GWK72)*, Pettijohns Cave (GWK29), Pigeon Cave (GWK57), Spooky Cave (GWK494)*.

Conservation status: IUCN: Least Concern; NatureServe: G5 (S4 in Georgia)

Comments: This species is common in caves throughout its range (Brandon, 1966; Cooper and Cooper, 1968; Miller and Niemiller, 2008), including several caves in Georgia (Buhlmann, 2001; Camp and Jensen, 2007).

\section{Genus Plethodon}

Plethodon glutinosus (Green, 1818) (TP) Northern Slimy Salamander

Localities: Bartow Co.: Busch Cave (GBT611)*; Catoosa Co.: Crane Cave (GCZ80)*; Chattooga Co.: Parkers Cave $(\mathrm{GKH} 119)^{*}$, Scoggins II Cave (GKH405)*; Dade Co.: Case Cavern (GDD1), Cemetery Pit (GDD64)* Chambliss Cave (GDD321), Daniel Cave, Hooker Cave (GDD90)*, Howards Waterfall Cave (GDD34)*, Hurricane Cave $(G D D 62)^{*}$, Johnsons Crook Cave (GDD17)*, Limestone Caverns (GDD140)*, Longs Creekside Cave (GDD45)*, Longs Rock Wall Cave $(G D D 101)^{*}$, Lower Valley Cave (GDD136)*, Morrison Spring Cave


Cave (GDD135)*, Wild Bills Dakota Cave (GDD596)*; Floyd Co.: Airport Cave (GFL189)*, Cave Springs Cave (GFL18)*, "Bear Bone Cave" (probably Silver Creek Cave) (GFL173)*; Polk Co.: White River Cave (GPO7)*; Walker Co.: Anderson Spring Cave (GWK46), Bible Spring Cave (GWK74)* Ellisons Cave (GWK51), Fingerhole Cave (GWK259)*, Gila Monster Cave (GWK379)*, Horseshoe Cave (GWK12)* Kinda Pretty Cave (GWK258)*, LittleJohn Cave (GWK280)*, Lofton Cave (GWK281)* $^{*}$ Missing Evan Well Cave (GWK488)* Mountain Cove Farm Cave No. 2 (GWK74), Nash Waterfall Cave (GWK72), Pettijohns Cave (GWK29), Pigeon Cave (GWK57), Roger Branch Cave (GWK204)*, Screech Owl Cave (GWK205), Slimy Slot Cave (GWK529) ${ }^{*}$, Smartt Farm Cave (GWK124)*, Spooky Cave (GWK494)*.

Conservation status: IUCN: Least Concern; NatureServe: G5 (S5 in Georgia).

Comments: This species is a common inhabitant of caves throughout its range (Dodd et al., 2001; Lewis, 2005; Godwin, 2008; Niemiller and Miller, 2009; Niemiller et al., 2016), including Georgia (Buhlmann, 2001; Camp and Jensen, 2007).

\section{Plethodon petraeus Wynn et al., 1988 (TP/TX) Pigeon Mountain Salamander}

Localities: Walker Co.: Harrisburg Cave (GWK85), Nash Waterfall Cave (GWK72) $^{\star}$, Pettijohns Cave (GWK29), Screech Owl Cave (GWK205).

Conservation status: IUCN: Vulnerable; NatureServe: G2 (S2 in Georgia); listed as Rare and considered a Species of Greatest Conservation Need in Georgia.

Comments: This species is endemic to Georgia, specifically on the eastern slope of Pigeon Mountain in Walker County. Although primarily associated with rock outcrops and exposures in hardwood forest, $P$. petraeus can be found around the entrances of some caves (Wynn et al., 1988; Camp and Jensen, 2007).

\section{Plethodon serratus Grobman, 1944 (TX) Southern Red-backed Salamander}

Localities: Walker Co.: Anderson Spring Cave (GWK46), Fingerhole Cave $($ GWK259)*, Mouldy Bat Pit $($ GWK257)*, Pettijohns Cave (GWK29).

Conservation status: IUCN: Least Concern; NatureServe: G5 (S5 in Georgia).

Comments: Unlike some other Plethodon salamanders, this species has rarely been reported from caves (Buhlmann, 2001). 
Plethodon ventralis Highton, 1997 (TP/TX) Zigzag Salamander complex

Localities: Dade Co.: Caboose Cave (GDD475)*, Case Caverns (GDD1)* $^{*}$ Daniel Cave, Hurricane Cave (GDD62)*, Howards Waterfall Cave (GDD34)*, Morrison Cave (GDD86) ${ }^{*}$, Rusty's Cave (GDD70)*, Sittons Cave (GDD9); Walker Co.: Anderson Spring Cave $(\mathrm{GWK} 46)^{\star}$, Harrisburg Cave (GWK85), Hogjowl Cave*, Horseshoe Cave (GWK12)*, Pettijohns Cave (GWK29), Screech Owl Cave (GWK205).

Conservation status: Plethodon ventralis - IUCN: Least Concern; NatureServe: G4 (S4 in Georgia); P. dorsalis - IUCN: Least Concern; NatureServe: G5 (SNR in Georgia);

Comments: Plethodon dorsalis and $P$. ventralis are closely related and difficult to distinguish morphologically. Some authors treat all populations in Georgia as P. ventralis (e.g., Camp, 2008); however, the contact zones between these two species have not been adequately delineated. Regardless, this complex is encountered regularly in caves (Buhlmann, 2001; Lewis, 2005; Camp and Jensen, 2007; Godwin, 2008; Niemiller and Miller, 2009).

\section{Genus Pseudotriton}

Pseudotriton ruber (Sonnini de Manoncourt and Latreille, 1801) (TP) Red Salamander

Localities: Dade Co.: Rusty's Cave (GDD70); Walker Co.: Anderson Spring Cave (GWK46), Ellisons Cave (GWK51), Fricks Cave (GWK14)*, Harrisburg Cave (GWK85), Mountain Cove Farm Cave No. 2 (GWK74), Pigeon Cave (GWK57), Roger Branch Cave (GWK204)*.

Conservation status: IUCN: Least Concern; NatureServe: G5 (S5 in Georgia).

Comments: This species is found frequently in the twilight zone and entrances of spring caves throughout the Interior Plateau and Appalachians karst regions (Buhlmann, 2001; Osbourn, 2005; Camp and Jensen, 2007; Miller et al., 2008; Niemiller and Miller, 2009; Niemiller et al., 2016). Reproduction in the dark zone of cave streams has been documented (Miller and Niemiller, 2005; Miller et al., 2008), including at Anderson Spring Cave in Walker County (Niemiller et al., 2006).

\section{Family Salamandridae}

\section{Genus Notophthalmus}

Notophthalmus viridescens (Rafinesque, 1820) (AC) Eastern Newt Localities: Dade Co.: Lower Valley Cave (GDD136)*.

Conservation status: IUCN: Least Concern; NatureServe: G5 (S5 in Georgia).

Comments: Additional records of this species exist from caves in Alabama and Tennessee (Godwin, 2008; Niemiller and Miller, 2009).

\section{Class Aves}

Order Accipitriformes

Family Cathartidae

Genus Cathartes

Cathartes aura (Linnaeus, 1758) (TX/AC) Turkey Vulture

Localities: Floyd Co.: Airport Cave (GFL189)*.

Conservation status: IUCN: Least Concern; NatureServe: G5 (S5 in Georgia).

Comments: This species nests on occasion at the entrances and within the twilight zones of caves (Coles, 1944; Lewis, 2005; Niemiller et al., 2016).

\section{Order Passeriformes \\ Family Tyrannidae \\ Genus Sayornis \\ Sayornis phoebe (Latham, 1790) (TX) Eastern Phoebe}

Localities: Catoosa Co.: Chapmans Cave (GCZ25)*; Chattooga Co.: Subligna Cave (GKH145)*; Dade Co.: Sittons Cave (GDD9)*; Walker Co.: Mountain Cove Farm Cave \#2 (GWK74)*, Anderson Springs Cave (GWK46)*.

Conservation status: IUCN: Least Concern; NatureServe: G5 (S5 in Georgia).

Comments: This species commonly nests in the entrances and twilight zones of caves in the TAG region (Lewis, 2005; Godwin, 2008; Niemiller et al., 2013, 2016).

\section{Class Mammalia}

Order Carnivora

Family Mustelidae

Genus Neovision

Neovision vison (Schreber, 1777) (AC) American Mink
Localities: Walker Co.: Roger Branch Cave (GWK204)*.

Conservation status: IUCN: Least Concern; NatureServe: G5 (S5 in Georgia).

Comments: This mustelid also has been observed near cave entrances infrequently in Tennessee (MLN, personal observation).

\section{Family Procyonidae \\ Genus Procyon}

Procyon lotor (Linnaeus, 1758) (TX) Raccoon

Localities: Catoosa Co.: Chapmans Cave $(\mathrm{GCZ25})^{*}$, Crane Cave $(\mathrm{GCZ80})^{*}$; Chattooga Co.: Subligna Cave (GKH145)*; Dade Co.: Chambliss Cave (GDD321), Ha-ha Cave (GDD256), Trenton Bone Cave (GDD16)*; Lapp Hole; Floyd Co.: Cave Springs Cave (GFL18)*; Walker Co.: Bee Rock Cave (GWK123)*, Fricks Cave (GWK14)*, Horseshoe Cave $\left(\right.$ GWK12) ${ }^{*}$, Smartt Farm Cave $\left(\right.$ GWK124) ${ }^{*}$, Spooky Cave (GWK494)*.

Conservation status: IUCN: Least Concern; NatureServe: G5 (S5 in Georgia).

Comments: Evidence of this species (tracks and scat) is common in caves throughout the central and eastern United States.

\section{Order Chiroptera}

Family Vespertilionidae

Corynorhinus rafinesquii (Lesson, 1827) (TX) Rafinesque's Bigeared Bat

Localities: Rabun Co.: Bascoms Cave.

Conservation status: IUCN: Least Concern; NatureServe: G3G4 (S3 in Georgia); listed as Rare and considered a Species of Greatest Conservation Need in Georgia.

Comments: This bat is considered rare in Georgia and has only been documented at one cave in the state.

\section{Genus Eptesicus}

Eptesicus fuscus (Palisot de Beauvois, 1796) (TX) Big Brown Bat Localities: Floyd Co.: Osborn Cave (GFL220)*; Polk Co.: Deatons Cave (GPO5), White River Cave (GPO7); Walker Co.: Fricks Cave (GWK14)*. Conservation status: IUCN: Least Concern; NatureServe: G5 (S5 in Georgia).

Comments: This species is observed frequently in TAG caves (Holliday, 2012; Flock, 2013, 2014; Niemiller et al., 2016), particularly in winter, but few records are known from caves in Georgia.

\section{Genus Lasiurus}

Lasiurus borealis Müller, 1776 (AC) Eastern Red Bat

Localities: Dade Co.: Byers Cave (GDD66); Polk Co.: Deatons Cave (GPO5).

Conservation status: IUCN: Least Concern; NatureServe: G3G4 (S5 in Georgia).

Comments: This forest-dwelling bat has been reported from caves infrequently (Mohr, 1952; Myers, 1960; Niemiller et al., 2016).

\section{Genus Myotis}

Myotis austroriparius (Rhoads, 1897) (TX) Southeastern Myotis

Localities: Decatur Co.: Climax Cave (GDC36); Grady Co.: Maloys Waterfall Cave (GGR27); Lee Co.: Chokee Cave (GLE575); Washington Co.: Sandersville Cave (GWS399).

Conservation status: IUCN: Least Concern; NatureServe: G4 (S3 in Georgia); considered a Species of Greatest Conservation Need in Georgia.

Comments: This is the most common Myotis species in caves of southwestern Georgia.

\section{Myotis grisescens Howell, 1909 (TX) Gray Bat}

Localities: Catoosa Co.: Chickamauga Cave (GCZ106); Chattooga Co.: Welcome Hill Cave (GKH163), Lowry Cave (GKH206); Dade Co.: Sittons Cave (GDD9); Polk Co.: Deatons Cave (GPO5), White River Cave (GPO7); Walker Co.: Anderson Spring Cave (GWK46), Fricks Cave (GWK14).

Conservation status: IUCN: vulnerable; NatureServe: G4 (S1 in Georgia); listed as Endangered under the U.S. Endangered Species Act; listed as Endangered and considered a Species of Greatest Conservation Need in Georgia.

Comments: In summer, this federally endangered bat is known to roost in just three caves in Chattooga, Walker, and Catoosa counties (Mar- 
tin, 2007), although several additional occurrences exist. Unlike several Myotis species, $M$. grisescens does not appear to be nearly as susceptible to White-nose Syndrome.

\section{Myotis leibii (Audubon and Bachman, 1842) (TX) Eastern} Small-footed Bat

Localities: Dade Co.: Case Cavern (GDD1), Howards Waterfall Cave (GDD34); Union Co.: cave near Young Harris.

Conservation status: IUCN: Endangered; NatureServe: G4 (S1 in Georgia).

Comments: This small bat is rarely observed in Georgia caves.

\section{Myotis lucifugus (LeConte, 1831) (TX) Little Brown Bat}

Localities: Bartow Co.: Kingston Saltpeter Cave (GBT11); Dade Co.: Byers Cave (GDD66), Case Cavern (GDD1), Howards Waterfall Cave (GDD34), Sittons Cave (GDD9); Polk Co.: Deatons Cave (GPO5), White River Cave (GPO7); Walker Co.: Anderson Spring Cave (GWK46), Ellisons Cave (GWK51), Fricks Cave (GWK14)*.

Conservation status: IUCN: Endangered; NatureServe: G3 (S3 in Georgia); considered a Species of Greatest Conservation Need in Georgia. Comments: This bat is encountered infrequently in Georgia caves during winter. Populations have sustained declines throughout its wide distribution in North America due to White-nose Syndrome. This species has not been observed during recent winter cave hibernacula surveys in Georgia (Morris and Ferrall, 2018).

\section{Myotis septentrionalis (Trovessart, 1897) (TX) Northern Long- eared Bat}

Localities: Bartow Co.: Davis Farm Cave (GBT222)*, Kingston Saltpeter Cave (GBT11); Dade Co.: Byers Cave (GDD66), Case Cavern (GDD1), Johnsons Crook Cave (GDD17)*, Sittons Cave (GDD9); Pickens Co.: Long Swamp Creek Cave; Polk Co.: Deatons Cave (GPO5), White River Cave (GPO7), Rabun Co.: Black Diamond Tunnel Cave; Walker Co.: Anderson Spring Cave (GWK46), Kinda Pretty Cave (GWK258)* Nash Waterfall Cave (GWK72)*.

Conservation status: IUCN: Near Threatened; NatureServe: G1G2 (S1S3 in Georgia); listed as Threatened under the U.S. Endangered Species Act; listed as Threatened and considered a Species of Greatest Conservation Need in Georgia.

Comments: This species can be found in low numbers in Georgia caves during winter. However, it is one of the bat species most impacted by White-nose Syndrome. It is now listed as Threatened under the U.S. Endangered Species Act as of 2015. This species has not been observed during recent winter cave hibernacula surveys in Georgia (Morris and Ferrall, 2018).

\section{Myotis sodalis Miller and Allen, 1928 (TX) Indiana Bat}

Localities: Chattooga Co.: Lowry Cave (GKH206); Dade Co.: Case Cavern (GDD1), Cave $4 \mathrm{mi} \mathrm{W}$ of Trenton, Sittons Cave (GDD9).

Conservation status: IUCN: Near Threatened; NatureServe: G2 (S1 in Georgia); listed as Endangered under the U.S. Endangered Species Act; listed as Endangered and considered a Species of Greatest Conservation Need in Georgia.

Comments: This bat is not commonly encountered in Georgia caves. Case Cavern and Sittons Cave are Priority 4 sites for this federally endangered species.

\section{Myotis sp. (TX) A Bat}

Localities: Chattooga Co.: Subligna Cave (GKH145)*.

Comments: This record is probably $M$. grisescens but identification could not be confirmed.

\section{Genus Perimyotis \\ Perimyotis subflavus (Cuvier, 1832) (TX) Tri-Colored Bat}

Localities: Bartow Co.: Alfords Cave, Anthonys Cave (GBT175) ${ }^{\star}$, Chert Chasm (GBT340)*, Jolley Cave (GBT187), Kingston Saltpeter Cave (GBT11), Ladds Lime Cave (GBT384 to GBT389); Bleckley Co.: Whistling Cave/Taylor Cave (GBL460/GBL461); Catoosa Co.: Chapmans Cave (GCZ25), Chickamauga Cave (GCZ106)*, Welcome Hill Cave (GKH163), Lowry Cave (GKH206), Parkers Cave (GKH119), Smiths Cave, Subligna Cave (GKH145), Trion Dam Cave (GKH158); Dade Co.: Trenton Bone Cave (GDD16), Alabama-Georgia Cave (GDD511), Boxcar Cave (GDD69)*, Byers Cave (GDD66), Caboose Cave (GDD475)*, Case Cavern (GDD1), Cave 4 mi W of Trenton, Cemetery Pit (GDD64)*, Chambliss Cave (GDD321), Dead Horse Cave (GDD111), Gypsy Cave
(GDD32), Ha-ha Cave (GDD256), Howards Waterfall Cave (GDD34)*, Hurricane Cave (GDD62)*, Johnsons Crook Cave (GDD17)*, Lapp Hole, Longs Rock Wall Cave (GDD101) ${ }^{\star}$, Lower Valley Cave (GDD136)*, Rising Fawn Exit Cave (GDD397), Rusty's Cave (GDD70)* Sittons Cave (GDD9), SSS Cave (GDD229)*, Upper Valley Cave (GDD135)*; Decatur Co.: "Bainbridge in Powell Hill Cave", Climax Cave (GDC36)*; Floyd Co.: Cave Spring Cave (GFL18), Osborn Cave (GFL220), Spout Springs Cave (GFL150); Gordon Co.: Rusty Cable Cave (GGO297)*; Grady Co.: Biscuits and Gravy Cave (GGR602), Glory Hole (GGR56), Maloys Waterfall Cave (GGR27)*, Long Swamp Creek Cave; Polk Co.: Deatons Cave (GPO5), White River Cave (GPO7)*; Randolph Co.: Griers Cave (GRA40); Union Co.: "Young Harris Bat Caves" (GUN28, GUN391 \& GUN392); Walker Co.: Allen Springs Cave (GWK318), Anderson Spring Cave (GWK46), Dry Creek, Ellisons Cave (GWK51), Fricks Cave (GWK14), Goat Cave (GWK184)*, Harris Cave, Horseshoe Cave (GWK12)*, Pettijohns Cave (GWK29), Pigeon Cave (GWK57), Roger Branch Cave (GWK204)*, Shook Cave (GWK190), Spooky Cave (GWK494)*; Randolph Co.: J C Jones Cave (GRA207)*; Whitfield Co.: Ketchums Cave (GWT13).

Conservation status: IUCN: Vulerable; NatureServe: G2G3 (S2 in Georgia); considered a Species of Greatest Conservation Need in Georgia. Comments: This species is the most common bat observed in Georgia caves during winter where it can be found hibernating individually or in small clusters on cave walls and ceilings. Like several Myotis species, $P$. subflavus is susceptible to White-nose Syndrome and population declines have been noted for several Georgia caves based on recent winter cave hibernacula surveys (Morris and Ferrall, 2018).

\section{Order Didelphimorphia \\ Family Didelphidae \\ Genus Didelphis}

Didelphis virginiana Kerr, 1792 (AC) Virginia Opossum

Localities: Walker Co.: Rocky Cave (GWK496)*.

Conservation status: IUCN: Least Concern; NatureServe: G5 (S1 in Georgia).

Comments: Opossums have been reported from a few caves in the eastern United States (Dearolf, 1956; Cliburn and Middleton, 1983; Holler et al., in review).

\section{Order Rodentia \\ Family Castoridae \\ Genus Castor}

Castor canadensis Kuhl, 1820 (TX) American Beaver

Localities: Walker Co.: Mountain Cove Farm Cave \#2 (GWK74)*.

Conservation status: IUCN: Least Concern; NatureServe: G5 (S5 in Georgia).

Comments: A collection of beaver-chewn branches was present in the cave. Beavers are known to build lodges inside the entrances of stream caves (e.g., Gore and Baker, 1989; Niemiller et al., 2016).

\section{Family Cricetidae \\ Genus Neotoma \\ Neotoma floridana (Ord, 1818) (TX) Eastern Woodrat}

Localities: Dade Co.: Afterbirth Cave (GDD153)*, Caboose Cave $\left(\right.$ GDD475) $^{*}$, Case Cavern (GDD1), Jeff's Hole Cave (GDD400)* Limestone Caverns (GDD140)*, Lower Valley Cave (GDD136)*, Sittons Cave (GDD9), SSS Cave (GDD229)*; Walker Co.: Anderson Spring Cave (GWK46), Bee Rock Cave (GWK123)*, Ellisons Cave (GWK51), Fingerhole Cave (GWK259)*, Fricks Cave (GWK14), Horseshoe Cave $($ GWK12)* Kinda Pretty Cave (GWK258)*, Mouldy Bat Pit (GWK257)*, Mountain Cove Farm Cave \#2 (GWK74)*, Nash Waterfall Cave (GWK72), Pettijohns Cave (GWK29), Pigeon Cave (GWK57), Rocky Cave (GWK496)*, Spooky Cave (GWK494)*.

Conservation status: IUCN: Least Concern; NatureServe: G5 (S5 in Georgia).

Comments: Both Neotoma floridana and N. magister (Allegheny Woodrat) occur in Georgia, although the contact zone in Georgia is unclear. Here we treat all records as $N$. floridana, but note that some occurrences may represent $N$. magister. Several records are based on indirect evidence of inhabitation, such as the presence of latrines, caches, and nests. 
Class Reptilia

Order Squamata

Family Colubridae

Genus Carphophis

Carphophis amoenus (Say, 1825) (AC) Eastern Worm Snake

Localities: Walker Co.: Flowing Stone Cave (GWK524)*.

Conservation status: IUCN: Least Concern; NatureServe: G5 (S5 in

Georgia).

Comments: This accidental also has been reported from caves and mines in West Virginia (Pauley, 1993; Osbourn, 2005).

\section{Genus Cemophora}

Cemophora coccinea (Blumenbach, 1788) (AC) Scarlet Snake

Localities: Greene Co.: Parrott Cave*.

Conservation status: IUCN: Least Concern; NatureServe: G5 (S4S5

in Georgia).

Comments: To our knowledge, this is the first report of this species

from a cave.

\section{Genus Diadophis}

Diadophis punctatus (Linnaeus, 1766) (AC) Ringneck Snake

Localities: Walker Co.: Screech Owl Cave (GWK205)*, Kinda Pretty Cave (GWK258).

\section{Discussion}

\section{Summary of biological records}

Our review of biodiversity in Georgia caves and other subterranean habitats identified 281 species, including 228 invertebrates and 53 vertebrates (Table S3) represented by more than 1200 occurrence records. There are $\sim 350$ additional records of taxa that have not been identified to species (Table S2). Of the taxa identified to species, five phyla (Annelida, Arthropoda, Chordata, Mollusca, and Platyhelminthes) are represented. The arthropods are the most diverse group documented with 195 species, including 50 arachnids, 34 crustaceans, and 78 insects. Fifty-one cave-obligate species (34 troglobites and 17 stygobites) have been reported from Georgia, and as many as a dozen additional troglobionts have been mentioned in the literature but are undescribed.

The biodiversity of a few caves has been studied using baits and repeated visits (e.g., Reeves and McCreadie, 2001; Campbell et al., 2011, 2012; Disney and Campbell, 2011). The application of such approaches in Howards Waterfall Cave (Dade County, with 88 total records), Horseshoe Cave (Walker County, 68 records), Pettijohns Cave (Walker County, 64 records), and Byers Cave (Dade County, 61 records) have provided the broadest picture of Georgia cave biodiversity.

\section{Vertebrates}

Fifty-three species of vertebrates have been reported from Georgia caves, including four fishes, 27 amphibians, five reptiles, two birds, and 15 mammals (Table 1). Mammal diversity was predominantly bats, with ten species. Most vertebrates reported from Georgia caves are accidental or occasional visitors, but several species of salamanders are common in caves, such as Eurycea lucifuga and Gyrinophilus porphyriticus, as are several cave-roosting bats and woodrats. Three vertebrate species are considered cave-obligates: the cavefish Typhlichthys subterranneus and the salamanders Eurycea wallacei and Gyrinophilus palleucus. All three species are known from few $(\leq 5)$ verified occurrences in the state, but also occur in adjacent states. The salamander Plethodon petraeus is endemic to Pigeon Mountain in Walker County. All the other vertebrates have been reported from caves in other states (Lewis, 2005; Godwin, 2008; Niemiller et al., 2016).

\section{Bats}

Ten species of bats have been reported from caves across Georgia, and the Tri-Colored Bat (Perimyotis subflavus) is known from more caves (67) in more counties (16) than any other animal in the state (Table 1). However, most bats are known from few caves, and cave-dwelling bats, in general, are of great conservation interest. Seven are "High Priority Species" in the current State Wildlife Action Plan (Georgia Department of Natural Resources; 2015) (Table 1). In addition, Rafinesque's Big-eared Bat (Corynorhinus rafinesquii) is designated "Rare" by Georgia, the Northern Longeared Bat (Myotis septentrionalis) is listed as "Threatened" under the U.S. Endangered Species Act and by the state of Georgia, and the Gray Bat (Myotis grisescens) and the Indiana Bat (Myotis sodalis) are both listed as "Endangered" under the U.S. Endangered Species Act and by the state of Georgia. Critical population centers for bats in Georgia include Fricks Cave in Walker County, which hosts a bachelor colony of Gray Bats during the summer, and Climax Cave in Decatur County, a major site for Southeastern Myotis (Myotis austroriparius). Fricks Cave is owned by the Southeastern Cave Conservancy, Inc. and is generally closed to visitation (currently it is open just one day a year during the winter). 
Table 1. Ecological classification, conservation status, and number of Georgia caves and counties from which vertebrate species have been documented. .

\begin{tabular}{|c|c|c|c|c|c|c|c|}
\hline Species & $\begin{array}{c}\text { Ecological } \\
\text { classification }\end{array}$ & $\begin{array}{c}\text { IUCN } \\
\text { Red List }^{a} \\
\end{array}$ & $\begin{array}{c}\text { NatureServe } \\
\text { status }\end{array}$ & $\begin{array}{c}\text { Government } \\
\text { status }^{b}\end{array}$ & $\begin{array}{l}\text { Caves/ } \\
\text { Wells }^{c}\end{array}$ & Counties $^{c}$ & $\begin{array}{c}\text { Georgia } \\
\text { endemic? }\end{array}$ \\
\hline \multicolumn{8}{|l|}{ Fishes } \\
\hline Ameiurus nebulosus & SXIAC & LC & G5, S5 & & 1 & 1 & \\
\hline Cottus bairdii & $\mathrm{SP}$ & LC & G5, S4 & & 1 & 1 & \\
\hline Cottus carolinae & SP & LC & G5, S4 & & 4 & 2 & \\
\hline Typhlichthys subterraneus & SB & VU & $\mathrm{G} 4, \mathrm{~S} 1$ & SE, SGCN & 5 & 2 & \\
\hline \multicolumn{8}{|l|}{ Amphibians (Frogs and Toads) } \\
\hline Anaxyrus fowleri & $A C$ & LC & G5, S5 & & 1 & 1 & \\
\hline Anaxyrus terrestris & $A C$ & LC & G5, S5 & & 1 & 1 & \\
\hline Hyla chrysoscelis & TX/AC & LC & G5, S5 & & 1 & 1 & \\
\hline Hyla gratiosa & $\mathrm{AC}$ & LC & G5, S5 & & 1 & 1 & \\
\hline Rana catesbeiana & $\mathrm{TX}$ & LC & G5, S5 & & 5 & 3 & \\
\hline Rana clamitans & $\mathrm{TX}$ & LC & G5, S5 & & 9 & 5 & \\
\hline Rana palustris & $\mathrm{TX}$ & LC & G5, S4 & & 11 & 2 & \\
\hline Rana sphenocephala & TXIAC & LC & G5, S5 & & 1 & 1 & \\
\hline Pseudacris crucifer & $A C$ & LC & G5, S5 & & 3 & 2 & \\
\hline Pseudacris feriarum & $A C$ & LC & G5, S5 & & 1 & 1 & \\
\hline \multicolumn{8}{|l|}{ Amphibians (Salamanders) } \\
\hline Ambystoma tigrinum & $A C$ & LC & G5, S3S4 & SGCN & 1 & 1 & \\
\hline Aneides aeneus & $\mathrm{TX}$ & NT & G3G4, S3 & SR, SGCN & 8 & 2 & \\
\hline Desmognathus conanti & $\mathrm{AC}$ & LC & G5, S5 & & 8 & 3 & \\
\hline Desmognathus ocoee & $A C$ & LC & G5, S5 & & 1 & 1 & \\
\hline Eurycea cirrigera & $\mathrm{TX}$ & LC & G5, S5 & & 6 & 4 & \\
\hline Eurycea guttolineata & $\mathrm{TX}$ & LC & G5, S4S5 & & 2 & 2 & \\
\hline Eurycea longicauda & $\mathrm{TP} / \mathrm{TX}$ & LC & G5, S4 & & 11 & 3 & \\
\hline Eurycea lucifuga & TP & LC & G5, S4 & & 52 & 9 & \\
\hline Eurycea wallacei & SB & VU & $\mathrm{G} 2, \mathrm{~S} 1$ & ST, SGCN & 3 & 2 & \\
\hline Gyrinophilus palleucus & SB & VU & G2G3, S1 & ST, SGCN & 2 & 1 & \\
\hline Gyrinophilus porphyriticus & TP & LC & G5, S4 & & 20 & 2 & \\
\hline Notophthalmus viridescens & $\mathrm{AC}$ & LC & G5, S5 & & 1 & 1 & \\
\hline Plethodon glutinosus & TP & LC & G5, S5 & & 44 & 7 & \\
\hline Plethodon petraeus & $\mathrm{TP} / \mathrm{TX}$ & VU & $\mathrm{G} 2, \mathrm{~S} 2$ & SR, SGCN & 4 & 1 & Yes \\
\hline Plethodon serratus & $\mathrm{TX}$ & LC & G5, S5 & & 4 & 1 & \\
\hline Plethodon ventralis & TP/TX & LC & $\mathrm{G} 4, \mathrm{~S} 4$ & & 14 & 2 & \\
\hline Pseudotriton ruber & TP & LC & G5, S5 & & 8 & 2 & \\
\hline \multicolumn{8}{|l|}{ Reptiles (Snakes) } \\
\hline Carphophis amoenus & $A C$ & LC & G5, S5 & & 1 & 1 & \\
\hline Cemophora coccinea & $A C$ & LC & G5, S4S5 & & 1 & 1 & \\
\hline Diadophis punctatus & $A C$ & LC & G5, S5 & & 2 & 1 & \\
\hline Nerodia sipedon & $\mathrm{AC}$ & LC & G5, S5 & & 1 & 1 & \\
\hline \multicolumn{8}{|l|}{ Reptiles (Turtles) } \\
\hline Terrapene carolina & $\mathrm{AC}$ & VU & G5, S5 & & 1 & 1 & \\
\hline \multicolumn{8}{|l|}{ Birds } \\
\hline Cathartes aura & TX/AC & LC & G5, S5 & & 1 & 1 & \\
\hline Sayornis phoebe & $\mathrm{TX}$ & LC & G5, S5 & & 4 & 4 & \\
\hline \multicolumn{8}{|l|}{ Mammals (Bats) } \\
\hline Corynorhinus rafinesquii & $\mathrm{TX}$ & LC & G3G4, S3 & SR, SGCN & 1 & 1 & \\
\hline Eptesicus fuscus & $\mathrm{TX}$ & LC & G5, S5 & & 4 & 3 & \\
\hline
\end{tabular}


Table 1. (Continued).

\begin{tabular}{|c|c|c|c|c|c|c|c|}
\hline Species & $\begin{array}{c}\text { Ecological } \\
\text { classification }\end{array}$ & $\begin{array}{c}\text { IUCN } \\
\text { Red List }^{\text {a }}\end{array}$ & $\begin{array}{c}\text { NatureServe } \\
\text { status }\end{array}$ & $\begin{array}{c}\text { Government } \\
\text { status }^{b}\end{array}$ & $\begin{array}{l}\text { Caves/ } \\
\text { Wells }^{c}\end{array}$ & Counties $^{c}$ & $\begin{array}{c}\text { Georgia } \\
\text { endemic? }\end{array}$ \\
\hline Lasiurus borealis & $A C$ & LC & G3G4, S5 & & 2 & 2 & \\
\hline Myotis austroriparius & $\mathrm{TX}$ & LC & $\mathrm{G} 4, \mathrm{~S} 3$ & SGCN & 4 & 4 & \\
\hline Myotis grisescens & $\mathrm{TX}$ & VU & $\mathrm{G} 4, \mathrm{~S} 1$ & FE, SE, SGCN & 8 & 5 & \\
\hline Myotis leibii & TX & EN & $\mathrm{G} 4, \mathrm{~S} 2$ & & 3 & 2 & \\
\hline Myotis lucifugus & $\mathrm{TX}$ & EN & G3, S1 & SGCN & 10 & 4 & \\
\hline Myotis septentrionalis & $\mathrm{TX}$ & NT & G1G2, S2S1 & FT, ST, SGCN & 13 & 6 & \\
\hline Myotis sodalis & $\mathrm{TX}$ & NT & $\mathrm{G} 2, \mathrm{~S} 1$ & FE, SE, SGCN & 4 & 2 & \\
\hline Perimyotis subflavus & $\mathrm{TX}$ & VU & G2G3, S2 & SGCN & 67 & 16 & \\
\hline \multicolumn{8}{|l|}{ Mammals (non-Bats) } \\
\hline Castor canadensis & TX & LC & G5, S5 & & 1 & 1 & \\
\hline Didelphis virginiana & $A C$ & LC & G5, S5 & & 1 & 1 & \\
\hline Neovision vison & $\mathrm{AC}$ & LC & G5, S5 & & 1 & 1 & \\
\hline Neotoma floridana & $\mathrm{TX}$ & LC & G5, S5 & & 22 & 2 & \\
\hline Procyon lotor & $\mathrm{TX}$ & $\mathrm{LC}$ & G5, S5 & & 13 & 5 & \\
\hline
\end{tabular}

Table 2. Ecological classification, conservation status, and number of Georgia caves and counties from which troglobionts have been documented. Abbreviations are the same as in Table 1, with the addition of SY = Symbiont.

\begin{tabular}{|c|c|c|c|c|c|c|c|}
\hline Species & $\begin{array}{c}\text { Ecological } \\
\text { classification }\end{array}$ & $\begin{array}{c}\text { IUCN } \\
\text { Red List }^{\mathrm{a}} \\
\end{array}$ & $\begin{array}{c}\text { NatureServe } \\
\text { status }\end{array}$ & $\begin{array}{c}\text { Government } \\
\text { status }^{\text {b }}\end{array}$ & $\begin{array}{l}\text { Caves/ } \\
\text { Wells }^{\mathrm{c}}\end{array}$ & Counties $^{\mathrm{C}}$ & $\begin{array}{c}\text { Georgia } \\
\text { endemic? }\end{array}$ \\
\hline \multicolumn{8}{|l|}{ Arachnids (pseudoscorpions) } \\
\hline Apochthonius minor & TB & & G1, SNR & & 2 & 2 & Yes \\
\hline Hesperochernes mirabilis & TB & & G5, SNR & & 16 & 5 & \\
\hline Kleptochthonius magnus & TB & & G1, SNR & & 2 & 2 & \\
\hline \multicolumn{8}{|l|}{ Arachnids (spiders) } \\
\hline Appaleptoneta fiskei & TB & & GNR, SNR & & 2 & 1 & Yes \\
\hline Liocranoides unicolor & TB & & G5, SNR & & 7 & 3 & \\
\hline Nesticus georgia & TB & & G1G2, SNR & & 3 & 1 & Yes \\
\hline Ozarkia georgia & TB & & GNR, SNR & & 3 & 1 & Yes \\
\hline Phanetta subterranea & TB & & G5, SNR & & 12 & 3 & \\
\hline Porrhomma cavernicola & TB & & G5, SNR & & 1 & 1 & \\
\hline \multicolumn{8}{|l|}{ Crustaceans (amphipods) } \\
\hline Crangonyx antennatus & SB & & G5, SNR & & 22 & 5 & \\
\hline Stygobromus ackerlyi & SB & & G1G2, SNR & & 3 & 3 & Yes \\
\hline Stygobromus dicksoni & SB & & G5, SNR & & 7 & 3 & \\
\hline Stygobromus doughertyensis & SB & & GNR, SNR & & 1 & 1 & \\
\hline Stygobromus grandis & SB & & G1, SU & & 1 & 1 & Yes \\
\hline Stygobromus minutus & SB & & G2G3, SU & & 2 & 1 & Yes \\
\hline \multicolumn{8}{|l|}{ Crustaceans (copepods) } \\
\hline Megacyclops donnaldsoni & SB & & G3G4, SNR & & 1 & 1 & \\
\hline \multicolumn{8}{|l|}{ Crustaceans (crayfish) } \\
\hline Cambarus cryptodytes & SB & LC & G2G3, S2 & ST, SGCN & 17 & 8 & \\
\hline \multicolumn{8}{|l|}{ Crustaceans (isopods) } \\
\hline Amerigoniscus curvatus & TB & & G1, SU & & 1 & 1 & Yes \\
\hline Amerigoniscus georgiensis & TB & & G1, SU & & 1 & 1 & Yes \\
\hline Amerigoniscus proximus & TB & & G1G2, SNR & & 2 & 2 & Yes \\
\hline Caecidotea cyrtorhynchus & SB & & G1, SU & & 3 & 1 & Yes \\
\hline Caecidotea hobbsi & SB & & G2G3, SNR & & 1 & 1 & \\
\hline
\end{tabular}


Table 2. (Continued).

\begin{tabular}{|c|c|c|c|c|c|c|c|}
\hline Species & $\begin{array}{c}\text { Ecological } \\
\text { classification }\end{array}$ & $\begin{array}{c}\text { IUCN } \\
\text { Red List }^{a} \\
\end{array}$ & $\begin{array}{c}\text { NatureServe } \\
\text { status }\end{array}$ & $\begin{array}{c}\text { Government } \\
\text { status }^{\text {b }}\end{array}$ & $\begin{array}{l}\text { Caves/ } \\
\text { Wells }^{c}\end{array}$ & Counties $^{c}$ & $\begin{array}{c}\text { Georgia } \\
\text { endemic? }\end{array}$ \\
\hline \multicolumn{8}{|l|}{ Crustaceans (isopods) } \\
\hline Caecidotea nickajackensis & SB & & $\mathrm{GH}, \mathrm{SNR}$ & & 1 & 1 & \\
\hline Caecidotea putea & SB & & G1G2, SNR & & 2 & 2 & \\
\hline Caecidotea richardsonae & SB & & G5, SNR & & 16 & 5 & \\
\hline \multicolumn{8}{|l|}{ Crustaceans (ostracods) } \\
\hline Uncinocythere warreni & SB/SY & & G1, SU & & 1 & 1 & Yes \\
\hline \multicolumn{8}{|l|}{ Diplurans } \\
\hline Litocampa cookei & TB & & G5, SNR & & 1 & 1 & \\
\hline \multicolumn{8}{|l|}{ Insects (beetles) } \\
\hline Batriasymmodes spelaeus & $\mathrm{TB} / \mathrm{TP}$ & & G3G4, SNR & & 4 & 3 & \\
\hline Pseudanophthalmus digitus & TB & & G1G2, SNR & & 3 & 1 & \\
\hline \multicolumn{8}{|l|}{ Pseudanophthalmus } \\
\hline fastigatus & TB & & G1, S1? & & 1 & 1 & Yes \\
\hline \multirow{2}{*}{\multicolumn{8}{|c|}{ Pseudanophthalmus }} \\
\hline & & & & & & & \\
\hline georgiae & TB & & $\mathrm{G} 1 \mathrm{G} 2, \mathrm{~S} 1 ?$ & & 4 & 2 & Yes \\
\hline Ptomaphagus fiskei & TB & & G1G2, SNR & & 10 & 1 & Yes \\
\hline Ptomaphagus whiteselli & TB & & G2G3, SNR & & 8 & 1 & \\
\hline \multicolumn{8}{|l|}{ Insects (flies) } \\
\hline Spelobia tenebrarum & TB & & G5, SNR & & 12 & 3 & \\
\hline \multicolumn{8}{|l|}{ Springtails } \\
\hline Pseudosinella christianseni & TB & & G5, SNR & & 15 & 2 & \\
\hline Pseudosinella hirsuta & TB & & G5, SNR & & 15 & 5 & \\
\hline Pseudosinella pecki & TB & & G2G3, SNR & & 2 & 2 & \\
\hline Pseudosinella spinosa & TB & & G5, SNR & & 1 & 1 & \\
\hline \multicolumn{8}{|l|}{ Myriapods (millipedes) } \\
\hline Ameractis satis & TB/TP & & G2G4, SNR & & 1 & 1 & \\
\hline Pseudotremia aeacus & TB & & G1G2, SNR & & 2 & 1 & \\
\hline Pseudotremia eburnea & TB & & G2G4, SNR & & 15 & 2 & \\
\hline Scoterpes austrinus & TB & & G3G4, SNR & & 16 & 3 & \\
\hline & & & G3G4T1T2, & & & & \\
\hline Scoterpes nudus & TB & & SNR & & 3 & 2 & Yes \\
\hline Scoterpes willreevesi & TB & & GNR, SNR & & 2 & 1 & \\
\hline \multicolumn{8}{|l|}{ Snails } \\
\hline Glyphyalinia specus & TB & $\operatorname{LC}^{d}$ & G3, SNR & & 6 & 3 & \\
\hline Helicodiscus barri & TB & $\operatorname{LC}^{d}$ & G3, SNR & & 2 & 2 & \\
\hline \multicolumn{8}{|l|}{ Flatworms } \\
\hline Sphalloplana georgiana & SB & & G1, SNR & & 1 & 1 & Yes \\
\hline \multicolumn{8}{|l|}{ Vertebrates (fish, salamanders) } \\
\hline Eurycea wallacei & SB & VU & $\mathrm{G} 2, \mathrm{~S} 1$ & ST, SGCN & 3 & 2 & \\
\hline Gyrinophilus palleucus & SB & VU & $\mathrm{G} 2 \mathrm{G} 3, \mathrm{~S} 1$ & ST, SGCN & 2 & 1 & \\
\hline Typhlichthys subterraneus & SB & VU & $\mathrm{G} 4, \mathrm{~S} 1$ & ST, SGCN & 5 & 2 & \\
\hline
\end{tabular}

a IUCN Red List: LC = Least Concern, VU = Vulnerable

${ }^{b}$ Government Status: SE = State Endangered, ST = State Threatened, SGCN = Species of Greatest Conservation Need (= State Wildlife Action Plan High Priority Species)

${ }^{\mathrm{C}} \mathrm{A}$ count of the number of occurrences. Caves/Wells and Counties refer to sites in Georgia only

${ }^{d}$ After Gladstone et al. 2018

Many bat populations across eastern North America are in decline as a result of White-nose Syndrome (WNS), which is caused by the fungus Pseudogymnoascus destructans (Blehert et al., 2009). First confirmed in northwestern Georgia during the winter of 2012-2013, WNS is now known from many counties in north Georgia (https://www.whitenosesyndrome.org/spreadmap). Over the past decade, WNS has impacted some cave-dwelling bats more than others; Tri-Colored Bats, Northern Long-eared Bats, Indiana Bats, and Little Brown Bats (Myotis lucifugus) have suffered steep population declines, whereas Gray Bats and Big Brown Bats (Eptesicus fuscus) have not (Francl et al., 2012; Campbell, 2017; Morris and Ferrall, 2018). Declines in bat populations, especially over such rapid timescales, will undoubtedly af- 


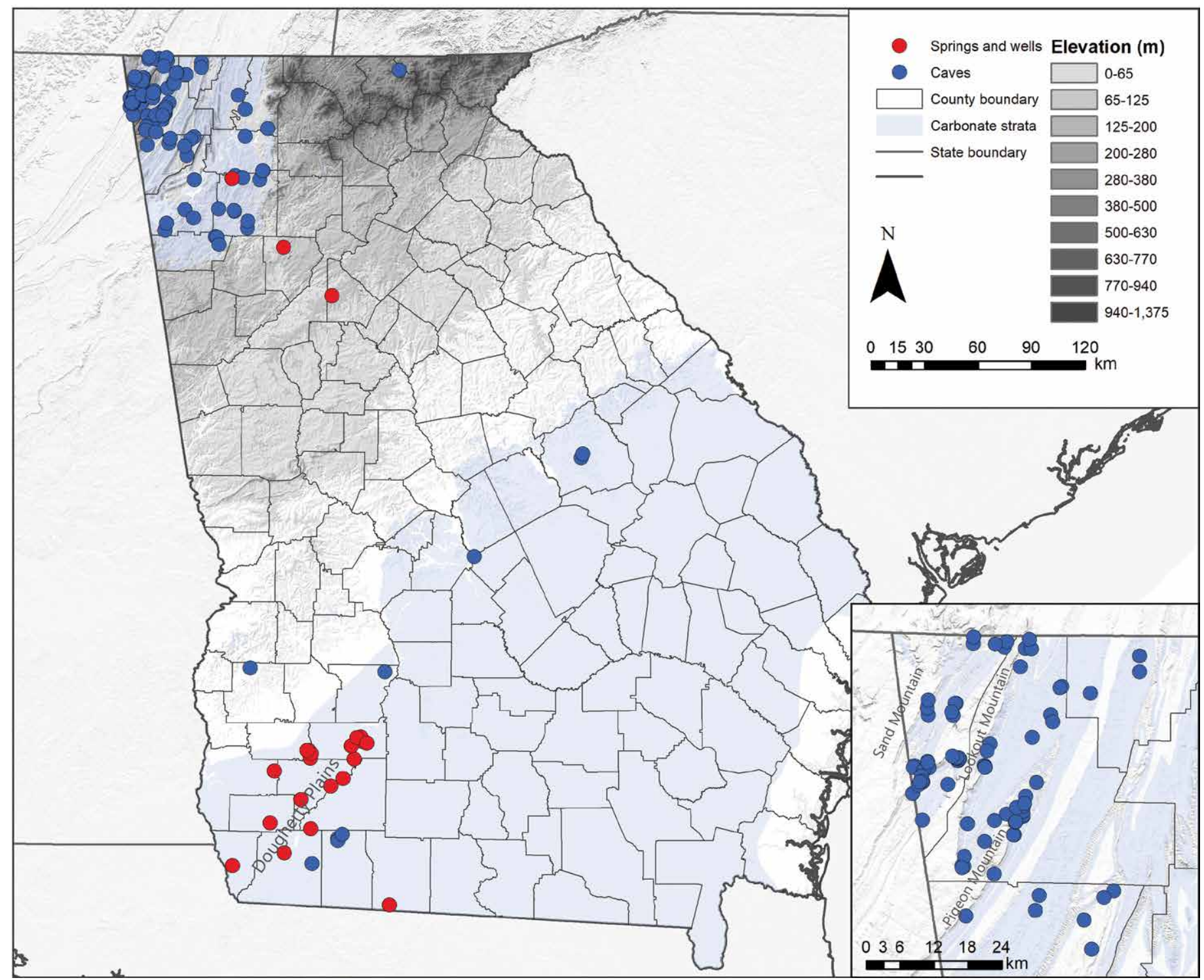

Figure 1. Distribution of the 142 georeferenced subterranean sites with biological records in Georgia. Caves are indicated by blue points, springs and wells by red points. Carbonate (karst) strata are indicated by light blue shading. An enlarged view of northwest Georgia is provided in the inset at the lower right. Geographic features mentioned in the paper are labeled. Cave locality data are from the Georgia Speleological Survey.

fect cave ecosystems because cave-dwelling bats are an important link between surface resources and cave habitats.

\section{Troglobionts}

Fifty-one species reported from caves in Georgia are considered troglobionts (34 terrestrial and 17 aquatic). Troglobitic diversity includes four phyla (Arthropoda, Mollusca, Platyhelminthes, and Chordata). Troglobitic species richness in Georgia is dominated by arthropods ( 45 species), distributed across the major arthropod subgroups of crustaceans (17 species), hexapods (13), arachnids (9), and myriapods (6). Two snails, one flatworm, and three vertebrates compose the remainder of the described troglobiotic fauna in the state (Table 2).

\section{Biogeography}

Nearly half of the Georgia's troglobionts are found in one of three geographically and hydrogeologically distinct areas: (1) west of Lookout Mountain in Lookout Valley; (2) east of Lookout Mountain, and (3) in the Dougherty Plains (Fig. 1). The taxa composing each group have ranges that do not overlap with members of the other groups.

Lookout Valley, primarily in Dade County, Georgia, is located west of Lookout Mountain and east of Sand Mountain (Fig. 1). This area is the southernmost extension of the Cumberland Plateau. Lookout Valley extends beyond Dade County to the north into Hamilton County, Tennessee, and to the south into DeKalb County, Alabama. At least seven troglobionts appear to be limited to Lookout Valley - the millipedes Scoterpes willreevesi and Pseudotremia aeacus, the 


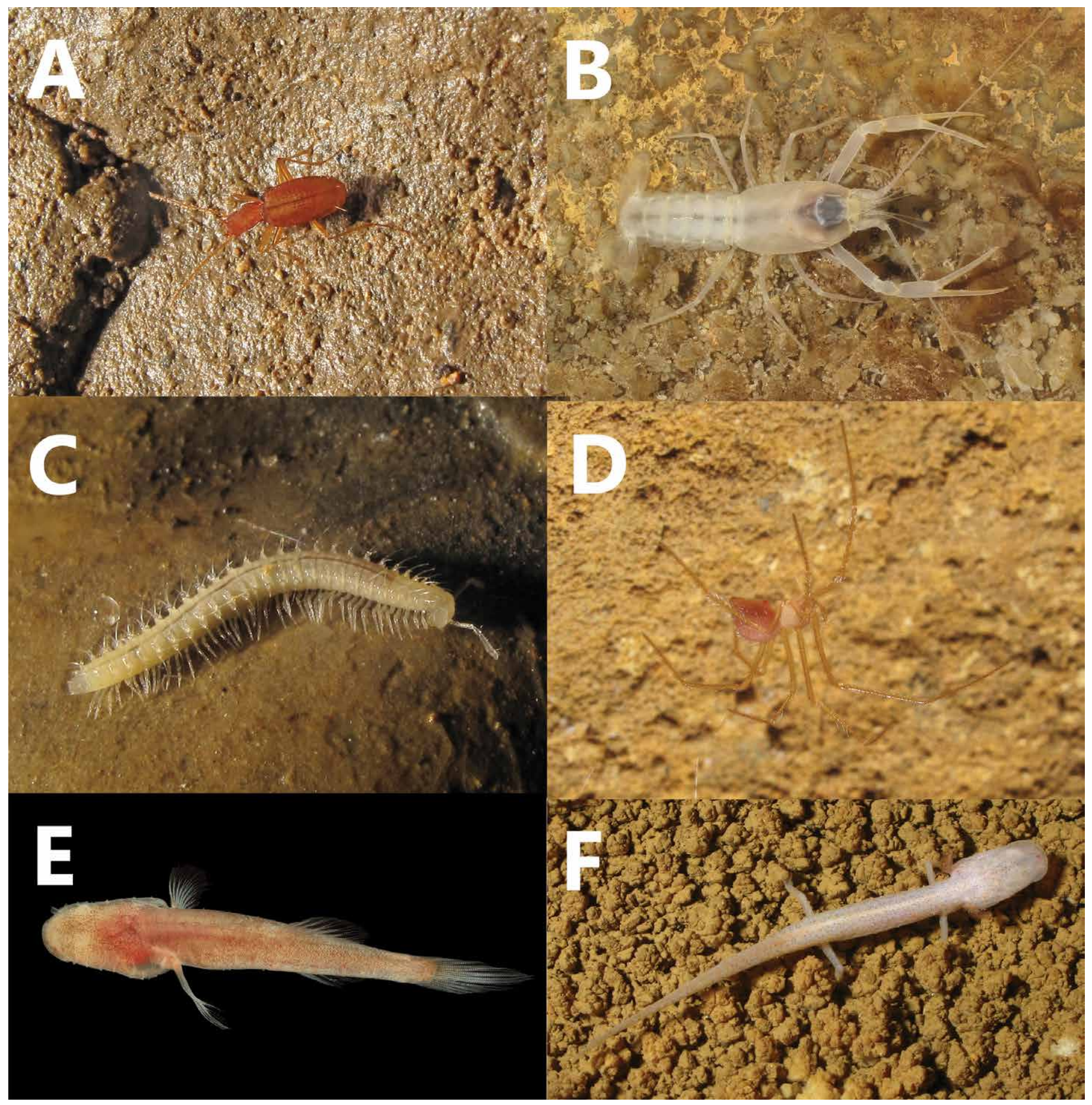

Figure 2. Representative troglobiotic fauna from Georgia caves: A) Pseudanophthalmus sp. from Four Kings Cave, Walker County; B) Cambarus cryptodytes from Climax Cave, Decatur County; C) Scoterpes nudus from White River Cave, Polk County; D) Nesticus georgia from Case Cave, Dade County; E) Typhlichthys subterraneus from Crane Cave, Catoosa County; and F) Eurycea wallacei from Salamander Cave, Jackson County, Florida. Photographs by Alan Cressler.

beetles Ptomaphagus whiteselli, Pseudanophthalmus digitus, and Pseudanophthalmus fulleri, and the spiders Nesticus georgia and Ozarkia georgia. The single-cave endemic flatworm Sphalloplana georgiana is another species known only from Lookout Valley, but unidentified Sphalloplana have been reported from Walker County, which may indicate a wider range for the species.

A second biogeographic group is located east of Lookout Mountain in Walker and Chattooga counties (Fig. 1). This group includes the beetles Ptomaphagus fiskei and Pseudanophthalmus georgia, the isopod Caecidotea cyrtorhynchus, the amphipod Stygobromus minutus, and the spider Appaleptoneta fiskei. In addition, four single-cave endemic 


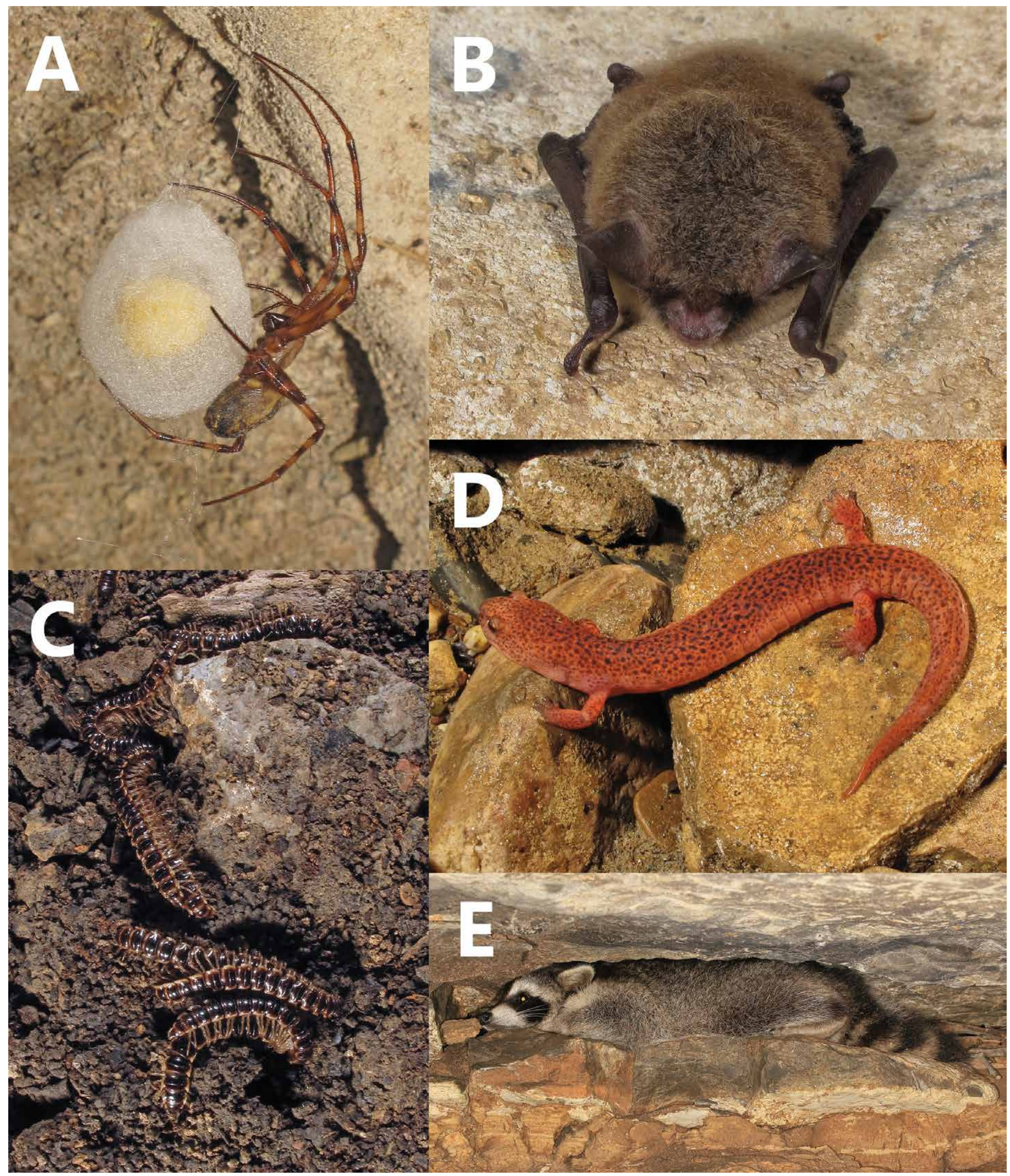

Figure 3. Representative non-troglobiotic fauna from Georgia caves: A) female Meta ovalis with egg case from Four Kings Cave, Walker County; B) Myotis lucifugus from Fricks Cave, Walker County; C) Oxidus gracilis from White River Cave, Polk County; D) Pseudotriton ruber from Fricks Cave, Walker County; and E) Procyon lotor from Trenton Bone Cave, Dade County. Photographs by Alan Cressler. 
species are found in this region: the beetle Pseudanophthalmus fastigatus, the amphipod Stygobromus grandis, and the isopods Amerigoniscus curvatus and $A$. georgiensis. The troglophilic springtail Pseudosinella georgia is also known only from this area. Within this group, there is a cluster of troglobionts limited to Pigeon Mountain - C. cyrtorhynchus, $S$. minutus, A. fiskei, and an undescribed Nesticus species. The cave-associated Pigeon Mountain Salamander (Plethodon petraeus) is also limited to Pigeon Mountain. Slightly further south, the millipede Scoterpes nudus and the amphipod Stygobromus ackerlyi are limited to caves in Bartow, Floyd, and Polk counties.

Lastly, several stygobitic taxa are limited to the Floridan aquifer system of the Dougherty Plains in southwestern Georgia near the Georgia-Alabama-Florida state junction (Fig. 1). The Dougherty Plains Cave Crayfish (Cambarus cryptodytes) is known from seven counties in Georgia (Fenolio et al., 2017), with a range that extends into Florida. The Georgia Blind Salamander (Eurycea wallacei) shares a similar range (Fenolio et al., 2013), as does the amphipod Stygobromus doughertyensis (Cannizaro et al., 2019). The single-cave endemic ostracod Uncinocythere warreni is known only from its host $C$. cryptodytes.

The remaining half of Georgia's troglobionts are found in one or more of the biogeographic clusters described above, and some have ranges that include much of the southern Appalachians and Interior Low Plateaus. Within these species, at least three patterns are present: (1) two stygobionts, the amphipod Crangonyx antennatus and the isopod Caecidotea richardonae, are common throughout the Appalachian Valley and Ridge, ranging from southern Virginia into Alabama; (2) two vertebrates, the Tennessee Cave Salamander (Gyrinophilus palleucus) and the Southern Cavefish (Typhlichthys subterraneus), are widespread west of the Cumberland Plateau (Niemiller et al., 2008; 2012) and appear to have spread east via the ancestral Tennessee River and associated drainage network into one or a few sites in northwestern Georgia (e.g., Niemiller et al., 2016); and, (3) a few of species are widespread in caves across the southern Appalachians and the Interior Low Plateaus, such as the spiders Phanetta subterranea and Porrhomma cavernicola, the fly Spelobia tenebrarum, the pseudoscorpion Hesperochernes mirabilis, and the springtail Pseudosinella hirsuta (Christman and Culver, 2001). Some of these taxa may represent cryptic species complexes of morphologically similar, yet genetically distinct, lineages. Cryptic diversity is a common discovery from phylogeographic studies of subterranean organisms (e.g., Bradford et al., 2010; Niemiller et al., 2012; Katz et al., 2018). The remaining troglobionts in Georgia do not fit into the patterns described above. Species from poorly known groups, like pseudoscorpions and springtails, compose many of the remaining taxa. For some species, a lack of records prevents any confident description of their distribution within Georgia and beyond.

\section{Endemism}

Troglobionts typically exhibit high rates of endemism (Christman et al., 2005), and we noted this pattern in the Georgia fauna. Seventeen of the 51 (33 \%) troglobionts known from Georgia are endemic to the state (Table 2). Thirteen of these species (26\%) are limited to a single county, and six species (12\%) are known from a single cave. These single-cave endemics are the beetle Pseudanophthalmus fastigatus (Horseshoe Cave, Walker County), the flatworm Sphalloplana georgiana (Howards Waterfall Cave, Dade County), the isopods Amerigoniscus curvatus (Horseshoe Cave, Walker County) and A. georgiensis (Pettijohns Cave, Walker County), the amphipod Stygobromus grandis (Parkers Cave, Chattooga County), and the ostracod Uncinocythere warreni (Climax Cave, Decatur County). Several other cave-associated non-troglobionts, such as the Pigeon Mountain Salamander, the springtail Pseudosinella georgia, the caddisfly Diplectrona marianae, and the spiders Pholcus dade and Pholcus lanieri, are also endemic to Georgia and have highly restricted ranges.

\section{Hotspots of troglobionts}

Troglobionts are not uniformly distributed across Georgia. Of the 670 caves known in the state, only $22(3.2 \%)$ are known to host five or more troglobionts, with 11 of those caves being in Dade County, nine in Walker County, and two in Chattooga County. Eight caves support ten or more troglobionts, these are: Pettijohns Cave (14 troglobionts), Byers Cave (13), Johnsons Crook Cave (12), Mountain Cove Farm Cave No. 1 (11), Howards Waterfall Cave (11), Cemetery Pit (11), Morrisons Cave (10), and Sittons Cave (10). Of these caves, six are in Dade County and two (Pettijohns Cave and Mountain Cove Farm Cave No. 1) are in Walker County. Maximum troglobiont diversity per cave is not as high in Georgia as in Tennessee, which has 24 troglobionts known from the Wonder/Crystal Cave system in Grundy County, or Alabama, where 24 troglobionts are known from Shelta Cave in Madison County. However, both Pettijohns Cave and Byers Cave would rank in the top ten caves in the state of Tennessee in terms of total troglobionts (Niemiller and Zigler, 2013).

\section{Conservation considerations}

The cave fauna of Georgia is diverse and includes numerous species of conservation concern, as well as many species with highly restricted ranges. This review provides background for conservation efforts related to cave biodiversity in Georgia. 
Species of conservation concern and threats to subterranean ecosystems. Many of the species found in Georgia caves are at an elevated risk of extinction because of their extremely small ranges. Of the troglobionts, 17 (33 $\%)$ are ranked "G1-Critically Imperiled" under NatureServe criteria, and the four troglobionts not ranked by NatureServe would likely be considered "G1" as well (Table 2). All of these species are considered short-range cave endemics (e.g., Niemiller et al., 2017), known from just a few sites within a limited geographic area. In addition, the Southern Cavefish, the Tennessee Cave Salamander, and the Dougherty Plains Cave Crayfish are ranked "S1_Critically Imperiled" in Georgia (Table 2). Although all three species are more wide-ranging in adjacent states, they are intrinsically vulnerable to extinction, as are most troglobionts (Culver et al., 2006; Culver and Pipan, 2009; Niemiller et al., 2018).

Cave communities can be impacted by modification of the surface landscape around caves and cave entrances, by water pollution that enters or moves through caves, or by human disturbance of cave habitats and populations. In the longer term, climate change may impact caves due to changing temperature and precipitation patterns, and indirectly by any changes in forest cover that result. In addition, the emerging infectious disease WNS has been present in Georgia for less than a decade. It appears to be affecting bat populations, in particular those of the Tri-Colored Bat, the most commonly encountered cave bat in Georgia (Morris and Ferrall, 2018). It will be some time before we reach a new steady state for bat population densities and distributions.

Caves on protected lands. Our Annotated List shows that, after half a century of work, there is a good deal known about cave biodiversity in Georgia. There are biological records from $18 \%$ (121 of 670) of Georgia caves, a higher frequency than reported for Tennessee, where $7 \%$ of caves have records of troglobionts (Niemiller and Zigler, 2013). In addition, a remarkably large proportion of the caves in Georgia are on protected lands. According to the records of the Georgia Speleological Survey, 165 caves are on property owned by federal, state, or local government. Government landholdings with significant numbers of caves include Chickamauga and Chattanooga National Military Park, Crockford-Pigeon Mountain Wildlife Management Area, and Cloudland Canyon State Park. At least 60 other caves are located on property owned or managed by land trusts, the Southeastern Cave Conservancy, Inc., or the National Speleological Society. In combination, around one third of all caves in Georgia are located on protected lands. Notably, many caves of particular biological importance are protected. For instance, of the eight caves known to host the ten or more troglobionts, seven are on protected lands. Several of these caves are well known (e.g., Pettijohns Cave, Howards Waterfall Cave), and receive regular visitation, which may be detrimental to cave communities.

Cave biodiversity knowledge shortfalls. Although much is known about cave biodiversity in Georgia, significant knowledge gaps remain, similar to subterranean biodiversity globally (Niemiller et al., 2018; Ficetola et al., 2019 ; Mammola et al., 2019). Although state-level conservation assessments for vertebrates are almost universally complete, such assessments are almost completely lacking for invertebrates (Tables 1, 2, and S3). Of the 49 invertebrate troglobionts known in Georgia, only one, the Dougherty Plains Cave Crayfish, has a state ("S") ranking under the NatureServe system, and only six have been ranked using IUCN Red List criteria (Table 2). As many of these invertebrates have highly restricted distributions, state-level conservation assessments are particularly valuable. Most of the species have global (“G”) rankings (Table 2), which should facilitate developing state rankings for the species. As models for how this could be done, recently published conservation assessments for Bactrurus cave amphipods (Niemiller and Taylor, 2016) and cave snails of the Interior Low Plateau and Appalachians karst regions (Gladstone et al., 2018) implemented both NatureServe and IUCN Red List assessment criteria, while Hutchins (2018) evaluated the conservation status of Texas groundwater invertebrates using the NatureServe methodology.

For most troglobionts in Georgia, we lack information about population sizes, population trends, and species distributions (i.e., the Prestonian and Wallacean shortfalls; Lomolino, 2004, Cardoso et al., 2011). Of the 17 troglobionts endemic to Georgia, only one is known from more than four sites (Table 2). In many cases, species are known from just one or a few collections, which limits our ability to assess population trends or persistence. As a specific example, the single-cave endemic beetle Pseudanophthalmus fastigatus was described from just two specimens collected in 1967 from Horseshoe Cave in Walker County. This species has not been collected since, and recent work in the cave (Reeves and McCreadie, 2001; this study) did not rediscover this population. Recent work on other Pseudanophthalmus species in Tennessee has shown that focused efforts often confirm the presence of long-lost populations and uncover new populations (Niemiller et al., 2017). Similar efforts are warranted for the many poorly-known troglobionts in Georgia.

More than two dozen undescribed species have been collected in caves in Georgia (Table 3). About half of these taxa are likely troglobionts, indicating a significant proportion of troglobiotic diversity in Georgia has not yet been described (i.e., the Linnaean shortfall; Brown and Lomolino, 1998). As discussed by Culver et al. (2013), not all of these taxa may turn out to be new species once they have been examined by taxonomic experts, but it is likely that many of them will be formally described. These taxa are dispersed across the major groups of arthropods and across the major karst regions of Georgia. As far as is currently known, many of these taxa could be single-cave endemics, which makes them conservation concerns. A full understanding of Georgia cave biodiversity will require the taxonomic evaluation of these taxa. 
Zigler, Niemiller, Stephen, Ayala, Milne, Gladstone, Engel, Jensen, Camp, Ozier, and Cressler

Table 3. Undescribed species reported from caves in Georgia.

\begin{tabular}{ccc}
\hline Taxon & Cave(s) & Comments \\
\hline Arachnids (harvestmen) & References \\
Phalangodidae: Bishopella & Dade County: Howards Waterfall Cave & $\begin{array}{c}\text { Described as "potentially } \\
\text { troglobitic." }\end{array}$
\end{tabular}

Arachnids (mites)

Rhagidiidae: hagidia

Arachnids (pseudoscorpions)

Chthoniidae: Aphrastochthonius

Chthoniidae: Apochthonius

Chthoniidae: Chthonius

Chthoniidae: Kleptochthonius

Chthoniidae: Mundochthonius

Chthoniidae

Neobisiidae: Lissocreagris

Neobisiidae: Microcreagris (sensu lato)

Neobisiidae: Microcreagris (sensu lato)

Arachnids (spiders)

Linyphiidae: Anibontes

Nesticidae: Nesticus n. sp. 1

Nesticidae: Nesticus n. sp. 2

Pholcidae: Pholcus

Crustaceans (amphipods)

Crangonyctidae: Stygobromus

Bartow County: Kingston Saltpeter Cave; Dade County: Byers Cave, Morrison Cave; Walker County: Bible Springs Cave, Pettijohns Cave

Dade County: Byers Cave, Longs Rock Wall

Chattooga County: Parker Cave

Walker County: Howards Waterfall Cave, Horseshoe Cave

Walker County: Rumble Rock Canyon Cave

Chattooga County: Parker Cave

Walker County: Mt. Cove Farm Cave

Walker County: Pettijohn Cave

Dade County: Johnson Crook Cave

Dade County: Hooker Cave

Chattooga County: Parkers Cave

Walker County: Anderson Spring Cave, Matthew Sink, Pigeon Cave (also possibly Mouldy Bat Pit and Fingerhole Cave)

Walker County: Lula Falls Cave

Bartow County: Ladds Lime Cave; Dade County: Hurricane Cave, Sittons Cave; Walker County: Fricks Cave, Spooky Cave

Dade County: Boxcar Cave, Caboose Cave
Holsinger and

Peck (1971)

One large female from entrance zone.

Two undescribed species represented.

\section{Many collected from entrance zone.}

From gut of Eurycea lucifuga found in dark zone. Partial specimen of an adult male. "Potentially new" because he did not place it in a genus.

Small, eyeless.

Potentially an error, not in Muchmore's material. Most Nearctic Microcreagris were transferred to other genera by Ćurčić (1981, 1984, 1989).

Campbell et al. (2012); this study

this study

this study

this study

Muchmore unpublished; this study

Muchmore unpublished

Holsinger and

Peck (1971);

Muchmore unpublished; this study

Holsinger and

Peck (1971);

Muchmore unpublished; this study

this study

this study

All sites on Pigeon Mountain. Eyeless.

Eyed.

Described as "several undescribed species of Pholcus."
Buhlmann (2001); Jensen and Ozier; this study

this study

Reeves et al. (2000)

Jensen and Ozier 
Table 3. (Continued).

\begin{tabular}{|c|c|c|c|}
\hline Taxon & Cave(s) & Comments & References \\
\hline \multicolumn{4}{|l|}{ Crustaceans (isopods) } \\
\hline Trichoniscidae: Miktoniscus & $\begin{array}{l}\text { Bartow County: Anthonys Cave; Chattooga County: } \\
\text { Blowing Springs Cave, Parker Cave; Dade County: } \\
\text { Howards Waterfall Cave, Sittons Cave; Decatur } \\
\text { County: Climax Cave; Randolph County: Griers Cave; } \\
\text { Walker County: Horseshoe Cave, Spooky Cave }\end{array}$ & $\begin{array}{l}\text { May represent } M \text {. } \\
\text { alabamensis or } \\
\text { undescribed species. }\end{array}$ & $\begin{array}{l}\text { Holsinger and } \\
\text { Peck (1971); } \\
\text { Muchmore } \\
\text { unpublished; } \\
\text { Reeves et al. } \\
\quad(2000)\end{array}$ \\
\hline \multicolumn{4}{|l|}{ Diplurans } \\
\hline Campodeidae & $\begin{array}{c}\text { Bartow, Chattooga, Dade, Floyd, Walker Counties: } 26 \\
\text { total sites }\end{array}$ & $\begin{array}{l}\text { These records likely } \\
\text { represent multiple } \\
\text { undescribed species. }\end{array}$ & $\begin{array}{l}\text { Holsinger and } \\
\text { Peck (1971), } \\
\text { Reeves et al. } \\
\text { (2000), Buhlmann } \\
\text { (2001), this study }\end{array}$ \\
\hline Staphylinidae: Subterrochus & Walker County: Mountain Cove Farm Cave & & $\begin{array}{l}\text { Holsinger and } \\
\text { Peck (1971) }\end{array}$ \\
\hline \multicolumn{4}{|l|}{ Insects (flies) } \\
\hline Sciaridae: Lycoriella & $\begin{array}{c}\text { Bartow County: Anthonys Cave; Dade County: Deans } \\
\text { Pit, Newsome Gap Cave; Walker County: Pettijohns } \\
\text { Cave, Horseshoe Cave }\end{array}$ & $\begin{array}{l}\text { Described as } \\
\text { "cavernicolous" }\end{array}$ & $\begin{array}{l}\text { Reeves et al. } \\
\quad(2000)\end{array}$ \\
\hline \multicolumn{4}{|l|}{ Insects (silverfish) } \\
\hline Nicoletiidae: Nicoletia & Walker County: Horseshoe Cave & & $\begin{array}{l}\text { Holsinger and } \\
\text { Peck (1971) }\end{array}$ \\
\hline \multicolumn{4}{|l|}{ Myriapods (centipedes) } \\
\hline Lithobiidae: Pampibius & Walker County: Cave Spring Cave & & $\begin{array}{l}\text { Holsinger and } \\
\text { Peck (1971) }\end{array}$ \\
\hline \multicolumn{4}{|l|}{ Myriapods (millipedes) } \\
\hline $\begin{array}{l}\text { Cleidogonidae: Pseudotremia } \\
\text { n. sp. } 1\end{array}$ & Dade County: Howards Waterfall Cave & Identified by W. Shear & this study \\
\hline $\begin{array}{l}\text { Cleidogonidae: Pseudotremia } \\
\text { n. sp. } 2\end{array}$ & Dade County: Hooker Cave & $\begin{array}{l}\text { Also collected in adjacent } \\
\text { Hamilton Co., TN. } \\
\text { Identified by W. Shear }\end{array}$ & this study \\
\hline
\end{tabular}

\section{Recommendations and Conclusions}

Many opportunities to improve our understanding of cave biodiversity in Georgia exist, including addressing the knowledge shortfalls by (1) conducting state-level conservation assessments of cave invertebrates, (2) focusing efforts to increase our knowledge on the ecology and life history of poorly-known and highly endemic troglobionts, and (3) supporting further study of the many undescribed taxa that have been reported. In addition, conservation resources could be focused on caves of biological interest. It is an important observation that many of the most biodiverse caves in Georgia are already on protected lands. Managing these sites for cave biodiversity is particularly important. However, there also are a handful of caves on private lands with important biological diversity that are worthy of further study and protection. Climax Cave in Decatur County is one of the longest caves in the state, and it supports populations of the Georgia Blind Salamander and the Dougherty Plain Cave Crayfish, which are both High Priority Species under the State Wildlife Action Plan, one single-cave endemic species, and is a significant Southeastern Myotis site. Horseshoe Cave in Walker County has the second-most biological records for any cave in the state and supports eight troglobionts, including two single-cave endemics and two potentially undescribed species. The Chelsea Gulf/Blowing Spring Cave system in Chattooga County hosts eight troglobionts, more than any other cave in Chattooga County. Parkers 
Cave in Chattooga County supports six troglobionts including one single-cave endemic, as well as three potentially undescribed species. Morrisons Cave in Dade County supports ten troglobionts. Crane Cave in Catoosa County supports the only known Appalachian Valley and Ridge population of the Southern Cavefish. Further protection of any of these sites would greatly support cave biodiversity in Georgia.

Although much attention is given to troglobionts and cave-roosting bats, caves and other subterranean ecosystems contain important habitats for many other non-troglobitic species for reproduction, hibernation, shelter, and other aspects of their life histories. For example, caves are important habitats for many plethodontid salamanders (Niemiller and Miller, 2009; Goricki et al., 2012), including several species in Georgia that use caves for shelter and reproduction (e.g., Buhlmann, 2001; Niemiller et al., 2006; Camp and Jensen, 2007). The importance of caves for other non-troglobitic taxa, particularly invertebrates, has not been well-studied and should be a priority of future research.

\section{Acknowledgments}

We thank the Georgia Speleological Survey and B. Aulenbach for providing information about the caves of Georgia. Comments from several reviewers, including S. Taylor and J. Lewis, improved the manuscript. The Georgia Department of Natural Resources kindly shared cave-related records from their databases. We thank W. Shear, C. Carlton, and M. Hedin for systematic assistance. Invaluable assistance in the field was provided by M. Abercrombie, B. Barker, P. Burress, J. Keetle, T. Lichtefeld, M. Rountree, and J. Wallace. Field work was permitted by the Georgia Department of Natural Resources under Scientific Collection Permit \#8934. This project was supported by the Cave Conservancy Foundation and The University of the South.

\section{Literature Cited}

Barr, T.C., Jr., 1953, Notes on the occurrence of ranid frogs in caves: Copeia, v. 1953, p. 60-61. doi.org/10.2307/1440250.

Barr, T.C., Jr., 1968, Cave ecology and the evolution of troglobites: in Dobzhansky, T., Hecht, M.K., and Steere, W.C., eds., Evolutionary Biology, vol. 2: New York, Appleton-Century-crofts, p. 35-102.

Barr, T.C., Jr., 1981, Pseudanophthalmus from Appalachian caves (Coleoptera: Carabidae): The engelhardti complex: Brimleyana, v. 5, p. $37-94$.

Barr, T.C., 2004, A classification and checklist of the genus Pseudanophthalmus Jeannel (Coleoptera: Carabidae: Trechinae): Virginia Museum of Natural History Special Publications, No. 11, p. 1-52.

Bellinger, P.F., Christiansen, K.A., and Janssens, F., 1996-2019, Checklist of the Collembola of the World; https://www.collembola.org/index.html (accessed August 2019).

Black, J., 1971, The cave life of Oklahoma. A preliminary study (excluding Chiroptera): Oklahoma Underground, v. 4, p. 2-53.

Blehert, D.S., Hicks, A.C., Behr, M., Meteyer, C.U., Berlowski-Zier, B.M., Buckles, E.L., Coleman, J.T., Darling, S.R., Gargas, A., Niver, R. and Okoniewski, J.C., 2009, Bat white-nose syndrome: an emerging fungal pathogen?: Science, v. 323, p. 227. doi:10.1126/science.1163874.

Bradford, T., Adams, M., Humphreys, W.F., Austin, A.D. and Cooper, S.J.B., 2010, DNA barcoding of stygofauna uncovers cryptic amphipod diversity in a calcrete aquifer in Western Australia's arid zone: Molecular Ecology Resources, v. 10, p. 41-50. doi:10.1111/j.17550998.2009.02706.x.

Brandon, R.A., 1966, Systematics of the Salamander Genus Gyrinophilus: Urbana, University of Illinois Press, Illinois Biological Monographs No. 35, p. 1-82. doi.org/10.5962/bhl.title.50088.

Brown, J.H., and Lomolino, M.V., 1998, Biogeography: Sunderland, Massachusetts: Sinauer Press.

Buhlmann, K.A., 2001, A biological inventory of eight caves in northwestern Georgia with conservation implications: Journal of Cave and Karst Studies, v. 63, p. 91-98.

Camp, C.D., 2008, Southern Zigzag Salamander, Plethodon ventralis, in Jensen, J.B., Camp, C.D., Gibbons W., and Elliott, M.J. eds., Amphibians and Reptiles of Georgia, University of Georgia Press, p. 227-229.

Camp, C.D., and Jensen, J.B., 2015, Eurycea lucifuga predation: Herpetological Review, v. 46, p. 609.

Camp, C.D., and Jensen, J.B., 2007, Use of twilight zones of caves by plethodontid salamanders: Copeia, v. 2007, p. 594-604.

Campbell, J.W., Woods, M., Ball, H.L., Pirkle, R.S., Carey, V. and Ray, C.H., 2011, Terrestrial macroinvertebrates captured with a baited ramp-pitfall trap from five limestone caves in North Alabama and Georgia (USA) and their association with soil organic matter: Journal of Natural History, v. 45, p. 2645-2659. doi:10.1080/00222933.2011.597884.

Campbell, J.W., Delong, B.E., Carey, V. and Ray, C., 2012, Survey of terrestrial invertebrate species from Byers Cave; Dade County, Georgia: Georgia Journal of Science, v. 70, p. 172-178.

Campbell, J., 2017, Tennessee Winter Bat Population and White-nose Syndrome Monitoring Report for 2016-2017: Tennessee Wildlife Resources Agency, https://www.tn.gov/content/dam/tn/twra/documents/WNS-2017-Annual-Monitoring-Report.pdf

Cannizzaro, A.G., Balding, D., Stine, M. and Sawicki, T.R., 2019, A new syntopic species of Stygobromus Cope, 1872 (Amphipoda: Crangonyctidae) from groundwaters in Georgia and Florida, USA, with notes on S. floridanus Holsinger \& Sawicki, 2016: Journal of Crustacean Biology, v. 39, p. 407-418. doi:10.1093/jcbiol/ruz034.

Cardoso, P., Erwin, T.L., Borges, P.A. and New, T.R., 2011, The seven impediments in invertebrate conservation and how to overcome them: Biological Conservation, v.144, p. 2647-2655. doi:10.1016/j.biocon.2011.07.024.

Carver, L.M., Perlaky, P., Cressler, A. and Zigler, K.S., 2016, Reproductive seasonality in Nesticus (Araneae: Nesticidae) cave spiders: PloS one, v. 11, e0156751. doi:10.1371/journal.pone.0156751.

Chamberlin, J.C., 1962, New and little-known false scorpions, principally from caves, belonging to the families Chthoniidae and Neobisiidae (Arachnida, Chelonethida): Bulletin of the American Museum of Natural History, v. 123, p. $299-352$.

Chamberlin, R.V., 1946, On some millipeds of Georgia. Entomological News, v. 57, p. 149-152.

Christiansen, K., 1960, A preliminary survey of the knowledge of North American cave Collembola: The American Midland Naturalist, v. 64, p. 39-44. doi.org/10.2307/2422892.

Christiansen, K., 1964, A revision of the nearctic members of the genus Tomocerus: Revue d'Ecologie et de Biologie du Sol., v. 1, p. $639-678$. 
Christiansen, K., 1966, The genus Arrhopalites (Collembola: Sminthuridae) in the United States and Canada: International Journal of Speleology, v. 2, p. 5. doi.org/10.5038/1827-806X.2.1.5.

Christiansen, K.A., and Bellinger, P.F., 1981, The Collembola of North America north of the Rio Grande. A taxonomic analysis. Part 4. Families Neelidae and Sminthuridae: Grinnell, lowa, Grinnell College, v. 4, 279 p.

Christiansen, K., and Bellinger, P., 1998, The Collembola of North America North of the Rio Grande: Grinnell College. Grinnell, lowa, 1322 p.

Christman, M.C., and Culver, D.C., 2001, The relationship between cave biodiversity and available habitat: Journal of Biogeography, v. 28 , p. 367-380. doi:10.1046/j.1365-2699.2001.00549.x. doi:10.1046/j.1365-2699.2001.00549.x.

Christman, M.C., Culver, D.C., Madden, M.K. and White, D., 2005, Patterns of endemism of the eastern North American cave fauna: Journal of Biogeography, v. 32, p.1441-1452. doi:10.1111/j.1365-2699.2005.01263.x.

Cliburn, J.W., and Middleton, A.L., Jr., 1983, The vertebrate cave fauna of Mississippi caves: National Speleological Society Bulletin, v. 45, p. 45-48.

Coleman, W.T. and Zigler, K.S., 2015, The rediscovery of Caecidotea nickajackensis in Tennessee and Alabama: Speleobiology Notes, v. 7 , p.10-13.

Coles, V., 1944, Nesting of the turkey vulture in Ohio caves: The Auk, v. 61, p. 219-228. doi.org/10.2307/4079365.

Cooper, J.E. and Cooper, M.R., 1968, Cave-associated herpetozoa II: salamanders of the genus Gyrinophilus in Alabama caves: Bulletin of the National Speleological Society, v. 30, p. 19-24.

Cope, E.D., and Packard, A.S., Jr., 1881, The fauna of the Nickajack Cave: The American Naturalist, v. 15, p. 877-882. doi.org/10.1086/272948.

Crosby, C.R., Bishop, S.C., 1924, Notes on the Opiliones of the southeastern United States with descriptions of new species. J. Mitchell Soc., v. 40, p. 8-26.

Culver, D.C., Christman, M. C., Elliott, W. R., Hobbs, H. H., and Reddell, J. R., 2003, The North American obligate cave fauna: regional patterns. Biodiversity \& Conservation, v. 12, p. 441-468. doi:10.1023/A:1022425908017.

Culver, D.C., Deharveng, L., Bedos, A., Lewis, J.J., Madden, M., Reddell, J.R., Sket, B., Trontelj, P., and White, D., 2006, The mid-latitude biodiversity ridge in terrestrial cave fauna: Ecography, v. 29, p. 120-128. doi:10.1111/j.2005.0906-7590.04435.x.

Culver, D.C., and Pipan T., 2009, The Biology of Caves and Other Subterranean Habitats: Oxford University Press, 254 p.

Culver, D.C., Trontelj, P., Zagmajster, M., and Pipan, T., 2013, Paving the way for standardized and comparable subterranean biodiversity studies: Subterranean Biology, v. 10, p. 43-50. doi:10.3897/subtbiol.10.4759.

Ćurčić, B.P.M., 1981, A revision of some North American pseudoscorpions (Neobisiidae, Pseudoscorpiones): Bulletin du Muséum d'Histoire Naturelle Belgrade Série B, v. 36, p. 101-107.

Ćurčić, B.P.M., 1984, A revision of some North American species of Microcreagris Balzan, 1892 (Arachnida: Pseudoscorpiones: Neobisiidae): Bulletin of the British Arachnological Society, v. 6, p. 149-166.

Ćurčić, B.P.M., 1989, Further revision of some North American false scorpions originally assigned to Microcreagris Balzan (Pseudoscorpiones, Neobisiidae): Journal of Arachnology, v. 17, p. 351-362.

Dearolf, K., 1956, Survey of North American cave vertebrates: Proceedings of the Pennsylvania Academy of Science, v. 30, p. $201-210$.

Disney, R.H. and Campbell, J., 2011, Scuttle flies (Diptera: Phoridae) from caves in Alabama and Georgia, USA: Subterranean Biology, v. 8, p. 65-67. doi:10.3897/subtbiol.8.1233.

Dodd, C.K. Jr., Griffey, M.L., and Corser, J.D., 2001, The cave associated amphibians of Great Smoky Mountains National Park: Review and monitoring: Journal of the Elisha Mitchell Scientific Society, v. 117, p. 139-149.

Dourson, D.C., 2010, Kentucky's Land Snails and Their Ecological Communities. Bakersville, North Carolina: Goatslug Publications, United States.

Epps, M.J., Menninger, H.L., LaSala, N. and Dunn, R.R., 2014, Too big to be noticed: cryptic invasion of Asian camel crickets in North American houses: PeerJ, v. 2, e523. doi:10.7717/peerj.523.

Espinasa, L., and Jeffery, W.R., 2003, A troglomorphic sculpin (Pisces: Cottidae) population: Geography, morphology and conservation status: Journal of Cave and Karst Studies, v. 65, p. 93-100.

Espinasa, L., Mendyk, A., Schaffer, E., and Cahill, A., 2013, The second northernmost cave-adapted fish in the world? Groundwork on the Tytoona Cave sculpin population: Northeastern Naturalist, v. 20, p. 185-196. doi.org/10.1656/045.020.0115.

Faber-Langendoen, D., Nichols, J., Master, L., Snow, K., Tomaino, A., Bittman, R., Hammerson, G., Heidel, B., Ramsay, L., Teucher, A., and Young, B., 2012, NatureServe Conservation Status Assessments: Methodology for Assigning Ranks, revised edition: Arlington, Virginia, NatureServe, $44 \mathrm{p}$.

Felderhoff, K.L., Bernard, E.C., and Moulton, J.K., 2010, Survey of Pogonognathellus Borner (Collembola: Tomoceridae) in the Southern Appalachians based on morphological and molecular data: Annals of the Entomological Society of America, v. 103, p. 472-491. doi:10.1603/ AN09105.

Fenolio, D.B., Niemiller, M.L., Gluesenkamp, A.G., McKee, A.M. and Taylor, S.J., 2017, New Distributional Records of the Stygobitic Crayfish Cambarus cryptodytes (Decapoda: Cambaridae) in the Floridan Aquifer System of Southwestern Georgia: Southeastern Naturalist, v. 16, p.163-182. doi:10.1656/058.016.0205.

Fenolio DB, Niemiller ML, Levy M, \& Martinez B., 2013, Conservation status of the Georgia blind salamander (Eurycea wallacei) from the Floridan Aquifer of Florida and Georgia: Reptiles and Amphibians, v. 20, p. 97 -111. Ficetola, G.F., Canedoli, C. and Stoch, F., 2019, The Racovitzan impediment and the hidden biodiversity of unexplored environments: Conservation Biology, v. 33, p. 214-216. doi.org/10.1111/ cobi.13179.

Flock, B., 2013, 2013 Tennessee Bat Population Monitoring and White Nose Syndrome: Nashville, Tennessee Wildlife Resources Agency, TWRA Wildlife Technical Report 13-22, 17 p.

Flock, B., 2014, 2014 Bat Population Monitoring and White Nose Syndrome Surveillance: Nashville, Tennessee Wildlife Resources Agency, TWRA Wildlife Technical Report 14-07, $15 \mathrm{p}$.

Fong, D.W., Porter, M.L., and Slay, M.E., 2012, Cave Life of the Virginias: A Field Guide to Commonly Encountered Species: Huntsville, Alabama, Biology Section of the National Speleological Society. $41 \mathrm{p}$.

Francl, K.E., Ford, W.M., Sparks, D.W. and Brack Jr, V., 2012, Capture and reproductive trends in summer bat communities in West Virginia: assessing the impact of white-nose syndrome: Journal of Fish and Wildlife Management, v. 3, p. 33-42. doi:10.3996/062011-JFWM-039.

Franz, R., Bauer, J., and Morris, T., 1994, Review of biologically significant caves and their faunas in Florida and south Georgia: Brimleyana, v. 20, p. 1-109.

GBIF.org (26 June 2019) GBIF Occurrence Download https://doi.org/10.15468/dl.k9t2s8 
Zigler, Niemiller, Stephen, Ayala, Milne, Gladstone, Engel, Jensen, Camp, Ozier, and Cressler

Georgia Department of Natural Resources, Wildlife Resources Division, 2015, State Wildlife Action Plan, https://georgiawildlife.com/sites/default/ files/wrd/pdf/swap/SWAP2015MainReport_92015.pdf

Georgia Speleological Survey, 2016, http://gss.io.caves.org/GSSWebsite/Home.html

Gertsch, W.J., 1984, The spider family Nesticidae (Araneae) in North America, Central America, and the West Indies: Texas Memorial Museum Bulletin, v. 31, p. 1-91.

Gladstone, N.S., Carter, E.T., McKinney, M.L., and Niemiller, M.L., 2018, Status and Distribution of the Cave-Obligate Land Snails in the Appalachians and Interior Low Plateau of the Eastern United States: American Malacological Bulletin, v. 36, p. 62-79. doi:10.4003/006.036.0107.

Gladstone, N.S., Niemiller, M.L., Pieper, E.B., Dooley, K.E., and McKinney, M.L., 2019, Morphometrics and phylogeography of the cave-obligate land snail Helicodiscus barri (Gastropoda, Stylommatophora, Helicodiscidae): Subterranean Biology, v. 30, p.1-32. doi:10.3897/subtbiol.30.35321.

Godwin, J.C., 2000, Reassessment of the historical and search for new localities of the Tennessee Cave Salamander (Gyrinophilus palleucus) in Alabama. Unpublished Report, Alabama Department of Conservation and Natural Resources, Montgomery.

Godwin, J.C., 2008, Biological Inventory of the Cave and Karst Systems of The Nature Conservancy's Sharp-Bingham Mountain Preserve: Auburn, Alabama, Alabama Natural Heritage Program, 40 p.

Goodnight, C.J. and Goodnight, M.L., 1942, New Phalangodidae (Phalangida) from the United States: American Museum Novitates, No. 1188.

Gore, J.A., and Baker, W.W., 1989, Beavers residing in caves in northern Florida: Journal of Mammalogy, v. 70, p. 677-678. doi:10.2307/1381451.

Goricki, S., Niemiller, M.L., and Fenolio, D.B., 2012, Salamanders, in White, W.B. and Culver, D.C. eds., Encyclopedia of Caves, 2nd Edition, Waltham, Massachusetts, Elsevier, p. 665-676. doi.org/10.1016/B978-0-12-383832-2.00098-0.

Graening, G.O., Fenolio, D.B., and Slay, M.E., 2011, Cave Life of Oklahoma and Arkansas: Exploration and Conservation of Subterranean Biodiversity: University of Oklahoma Press.

Hale, J.A. and Streever, W.J., 1994, Cave fauna distribution within fully-flooded cave systems in Florida: Journal of Freshwater Ecology: v. 9, p. 171-174. doi.org/10.1080/02705060.1994.9664883.

Hart, D.G., and Hart, Jr., C.W., 1974, The ostracod family Entocytheridae: Academy of Natural Sciences of Philadelphia, v. 18, p. 1-239.

Harvey, M.S., 1990, Catalogue of the Pseudoscorpionida: Manchester, United Kingdom, Manchester University Press, 726 p.

Harvey, M.S., 2013, Pseudoscorpions of the World, version 3.0. Western Australian Museum, Perth, http://museum.wa.gov.au/catalogues-beta/ pseudoscorpions (accessed June 2019).

Hedin, M.C., 1997, Speciational history in a diverse clade of habitat-specialized spiders (Araneae: Nesticidae: Nesticus): inferences from geographic-based sampling: Evolution, v. 51, p.1929-1945. doi:10.1111/j.1558-5646.1997.tb05115.x.

Hedin, M.C., 2001, Molecular insights into species phylogeny, biogeography, and morphological stasis in the ancient spider genus Hypochilus (Araneae: Hypochilidae): Molecular Phylogenetics and Evolution, v. 18, p. 238-251. doi:10.1006/mpev.2000.0882.

Hedin, M., and Thomas, S.M., 2010, Molecular systematics of eastern North American Phalangodidae (Arachnida: Opiliones: Laniatores), demonstrating convergent morphological evolution in caves: Molecular Phylogenetics and Evolution, v. 54, p.107-121. doi:10.1016/j. ympev.2009.08.020.

Hertl, P.T., 1981, A preliminary inventory survey and management plan for the Bat Cave complex, Bat Cave, North Carolina. Unpublished report for the North Carolina Nature Conservancy.

Himes, J., Beckett, D.C., and Trousdale, A.W., 2004, Survey of salamanders in Mississippi limestone caves: Southeastern Naturalist, v. 3 , p. 241-248. doi:10.1656/1528-7092(2004)003[0241:SOSIML]2.0.CO;2.

Hobbs Jr, H.H., Hobbs III, H.H. and Daniel, M.A., 1977, A review of the troglobitic decapod crustaceans of the Americas: Smithsonian Contributions to Zoology, v. 244, p. 1-182. doi:10.5479/si.00810282.244.

Hobbs Jr, H.H. and Walton, M., 1968, New entocytherid ostracods from the southern United States: Proceedings of the Academy of Natural Sciences of Philadelphia, v. 120, p. 237-252.

Hobbs III, H.H., 2012, Diversity patterns in the United States. In: White, W.B., Culver, D.C., editors. Encyclopedia of Caves, 2nd edition. Amsterdam: Academic Press. p. 251-264. doi:10.1016/B978-0-12-383832-2.00033-5.

Holler Jr., C., Mays, J.D., and Niemiller, M.L., in press, The fauna of caves and other subterranean habitats of North Carolina, USA: Journal of Cave and Karst Studies.

Holliday, C., 2012, 2012 White-Nose Syndrome Disease Surveillance and Bat Population Monitoring Report. A Report of the Tennessee WNS Response Cooperators: Tennessee Chapter of The Nature Conservancy, $10 \mathrm{p}$.

Holmberg, R.G., Angerilli, N.P.D., LaCasse L.J., 1984, Overwintering aggregations of Leiobunum paessleri in caves and mines (Arachnida, Opiliones): Journal of Arachnology, v. 12, p. 195-204.

Hoff, C.C.,1946, A study of the type collections of some pseudoscorpions originally described by Nathan Banks: Journal of the Washington Academy of Sciences, v. 36, p. 195-205.

Hoffman, R.L., 1981, On the taxonomic status, distribution, and subspecies of the milliped Pseudotremia fracta Chamberlin (Chordeumatida, Cleidogonidae): Brimleyana, v. 5, p.135-144.

Holman, J.A. 1958, The Pleistocene herpetofauna of Sabertooth Cave, Citrus County, Florida. Copeia, v. 4, p. 276-280. doi:10.2307/1439958.

Holsinger, J.R., 1978, Systematics of the subterranean amphipod genus Stygobromus (Crangonyctidae): Part II. Species of the eastern United States: Smithsonian Contributions to Zoology, v. 266, p. 1-144. doi:10.5479/si.00810282.266.

Holsinger, J.R. and Peck, S.B., 1971, The invertebrate cave fauna of Georgia: National Speleological Society Bulletin, v. 33, p. $23-44$.

Holt, P.C., 1973, A summary of the branchiobdellid (Annelida: Clitellata) fauna of Mesoamerica: Smithsonian Contributions to Zoology, no. 142, p. 1-40. doi:10.5479/si.00810282.142.

Hubbell, T.H., 1936, A monographic revision of the genus Ceuthophilus (Orthoptera, Gryllacrididae, Rhaphidophorinae): University of Floridal Publications, Biological Science Series, v. 2, p. 1-551.

Hubbell, T.H. and Norton, R.M., 1978, The systematics and biology of the cave-crickets of the North American tribe Hadenoecini (Orthoptera: Saltatoria: Ensifera: Rhaphidophoridae: Dolichopodinae): Miscellaneous Publications, Museum of Zoology, University of Michigan, v. 156, p. $1-124$.

Huber, B.A., 2011, Revision and cladistics analysis of Pholcus and closely related taxa (Araneae, Pholcidae): Bonner Zoologische Monographien, v. 58, p. 1-509.

Hubricht, L., 1962, New species of Helicodiscus from the eastern United States: The Nautilus, 75, p. 102-107. doi.org/10.5962/bhl.part.25951.

Hubricht, L., 1964, The land snails of Georgia: Sterkiana, v. 16, p. 5-10. 
Hubricht, L., 1985, The distributions of the native land mollusks of the eastern United States: Fieldiana, v. 24, p. 1-191. doi:10.5962/bhl.title.3329.

Huntsman, B.M., Venarsky, M.P., Benstead, J.P., and Huryn, A.D., 2011, Effects of organic matter availability on the life history and production of a top vertebrate predator (Plethodontidae: Gyrinophilus palleucus) in two cave streams: Freshwater Biology, v. 56, p. 1746-1760. doi. org/10.1111/j.1365-2427.2011.02609.x.

Hutchins, B.T., 2018, The conservation status of Texas groundwater invertebrates: Biodiversity and Conservation, v. 27, p. 475-501. doi:10.1007/ s10531-017-1447-0.

Hutchinson, V.H., 1966, Eurycea lucifuga: Catalogue of American Amphibians and Reptiles, 24, p. 1-2.

Hyman, L., 1954, North American Triclad Turbellaria, XIII: Three new cave planarians: Proceedings of the United States National Museum, v. 103, p. 563-573. doi.org/10.5479/si.00963801.103-3333.563.

International Union for the Conservation of Nature, 2012, IUCN Red List Categories and Criteria: Version 3.1. Second edition: Gland, Switzerland, and Cambridge, UK, IUCN, $32 \mathrm{p}$.

Katz, A.D., Taylor, S.J. and Davis, M.A., 2018, At the confluence of vicariance and dispersal: Phylogeography of cavernicolous springtails (Collembola: Arrhopalitidae, Tomoceridae) codistributed across a geologically complex karst landscape in Illinois and Missouri: Ecology and Evolution, v. 8, p.10306-10325. doi:10.1002/ece3.4507.

Kenk, R., 1977, Freshwater Triclads (Turbellaria) of North America, IX, the Genus Sphalloplana: Smithsonian Contributions to Zoology, No. 246. doi.org/10.5479/si.00810282.246.

Koponen, S., 1995, Quelques opilions (Arachnida) de la Province de Québec: Fabreries, v. 20, p. 1-5.

Lavoie, K., Bordi, J., Elwess, N, Soroka, D., and Burgess, M., 2019, Colonization of a newly cleaned cave by a camel cricket: Asian invasive or native?: Speleobiology Notes, v. 10, p. 1-8.

Ledford, J., Paquin, P., Cokendolpher, J., Campbell, J. and Griswold, C., 2011, Systematics of the spider genus Neoleptoneta Brignoli, 1972 (Araneae: Leptonetidae) with a discussion of the morphology and relationships for the North American Leptonetidae: Invertebrate Systematics, v. 25, p. 334-388. doi:10.1071/IS11014.

Leray, V.L., Caravas, J., Friedrich, M. and Zigler, K.S., 2019, Mitochondrial sequence data indicate "Vicariance by Erosion" as a mechanism of species diversification in North American Ptomaphagus (Coleoptera, Leiodidae, Cholevinae) cave beetles: Subterranean Biology, v. 29, p. 35-57. doi:10.3897/subtbiol.29.31377.

Lewis, J.J., 2005, Bioinventory of Caves of the Cumberland Escarpment Area of Tennessee. Final Report to Tennessee Wildlife Resources Agency \& The Nature Conservancy of Tennessee: Lewis \& Associates, 158 p.

Lewis, J.J., 2009, On the identity of Caecidotea nickajackensis (Crustacea: Isopoda: Asellidae): Proceedings of the Biological Society of Washington, v. 122, p. 215-224. doi:10.2988/08-47.1.

Lewis, J.J. and Reid, J.W., 2007, Patterns and processes of groundwater invasion by copepods in the interior low plateaus of the United States: Acta Carsologica, v. 36, p. 279-289. doi:10.3986/ac.v36i2.197.

Lomolino, M.V., 2004, In: M.V. Lomolino and L.R. Heaney (Eds.), Conservation biogeography. Frontiers of biogeography: New directions in the geography of nature: Sunderland, Massachusetts: Sinauer Associates, p. 293-296.

Mammola, S, Cardoso, P., Culver, D.C., Deharveng, L., Ferreira, R.L., Fiser, C., Galassi, D.M.P., Griebler, C., Halse, S., Humphreys, W.F., Isaia, M., Malard, F., Martinez, A., Moldovan, O.T., Niemiller, M.L., Pavlek, M., Reboleira, A.S.P.S., Souza-Silva, M., Teeling, E.C., Wynne, J.J., and Zagmajster, M., 2019, Scientists' warning on the conservation of subterranean ecosystems: BioScience, v. 69, p. 641 -650.

Marshall, S.A. and Peck, S.B., 1985a, The origin and relationships of Spelobia tenebrarum (Aldrich), a troglobitic, eastern North American, sphaerocerid fly: The Canadian Entomologist, v. 117, p. 1013-1015. doi:10.4039/Ent1171013-8.

Marshall, S.A. and Peck, S.B., 1985b, Distribution of cave-dwelling Sphaeroceridae (Diptera) of eastern North America: Proceedings of the Entomological Society of Ontario, v. 115, p. 37-41.

Martin, C.O., 2007, Assessment of the Population Status of the Gray Bat (Myotis grisescens): Army Endangered Species Research Lab, No. ERDC/EL-TR-07-22, p. 1-97.

Means, D.B, 2005, Haideotriton wallacei Carr, 1939. Georgia blind salamander: in M. Lannoo, ed. Amphibian Declines: The Conservation Status of United States Species. University of California Press, Berkeley, California, p. 779-780.

Miller, B.T. and Niemiller, M.L., 2005, Pseudotriton ruber (red salamander). Reproduction: Herpetological Review, v. 36, p. 429.

Miller, B.T., and Niemiller, M.L., 2008, Distribution and relative abundance of Tennessee Cave Salamanders (Gyrinophilus palleucus and Gyrinophilus gulolineatus) with an emphasis on Tennessee populations: Herpetological Conservation and Biology, v. 3, p. 1-20.

Miller, B.T. and Niemiller, M.L., 2012, Gyrinophilus palleucus: Catalogue of American Amphibians and Reptiles, 884, p. 1-7.

Miller, B.T., Niemiller, M.L., and Reynolds, R.G., 2008, Observations on egg-laying behavior and interactions among attending female Red Salamanders (Pseudotriton ruber) with comments on the use of caves by this species: Herpetological Conservation and Biology, v. 3, p. 203-210.

Miller, J.A., 2005, A redescription of Porrhomma cavernicola Keyserling (Araneae, Linyphiidae) with notes on Appalachian troglobites: Journal of Arachnology, v. 33, p. 426-439. doi:10.1636/04-51.1.

Mohr, C.E., 1952, A cave record for the red bat, Lasiurus b. borealis: Bulletin of the National Speleological Society, v. 14, p. 62-63.

Morris, T., and Ferrall, E., 2018, 2018 White-nose Syndrome Season Summary: https://view.publitas.com/georgia-department-of-natural-resources/white-nose-syndrome-in-georgia-2018-report/

Muchmore, W.B., 1969, New species and records of cavernicolous pseudoscorpions of the genus Microcreagris (Arachnida, Chelonethida, Neobisiidae, Ideobisiinae): American Museum Novitates, no. 2392, p. 1-21.

Muchmore, W.B., 1974, Clarification of the genera Hesperochernes and Dinocheirus (Pseudoscorpionida, Chernetidae): Journal of Arachnology, v. 2, p. 25-36.

Muchmore, W.B., 1976, New species of Apochthonius, mainly from caves in central and eastern United States (Pseudoscorpionida, Chthoniidae): Proceedings of the Biological Society of Washington, v. 89, p. 67-80.

Muchmore, W.B., and Cokendolpher, J.C., 1995, Generic placement of the Empire Cave Pseudoscorpion, Microcreagris imperialis (Neobisiidae), a potentially endangered cave arachnid: Journal of Arachnology, v. 23, p. 171-176.

Myers, R.F., 1960, Lasiurus from Missouri caves: Journal of Mammalogy, v. 41, p. 114-117. doi.org/10.2307/1376526.

Niemiller M.L., Bichuette, E., and Taylor, S.J., 2018, Conservation of cave fauna in Europe and the Americas. P. 451-478 in: Ecological Studies: Cave Ecology (Moldovan, O.T., Kovac. L., and Halse, S., eds). Springer. doi:10.1007/978-3-319-98852-8_22.

Niemiller, M.L., Fenolio, D.B., and Zigler, K.S., 2012, The obligate cave fauna of Georgia: Bulletin of the Georgia Speleological Society, p. 6-12.

Niemiller, M.L., Fitzpatrick, B.M., and Miller, B.T., 2008, Recent divergence with gene flow in Tennessee cave salamanders (Plethodontidae: Gyrinophilus) inferred from gene genealogies: Molecular Ecology, v. 17, p. 2258-2275. doi:10.1111/j.1365-294X.2008.03750.x. 
Zigler, Niemiller, Stephen, Ayala, Milne, Gladstone, Engel, Jensen, Camp, Ozier, and Cressler

Niemiller, M.L. and Miller, B.T., 2007, Subterranean reproduction of the southern two-lined salamander (Eurycea cirrigera) from Short Mountain, Tennessee: Herpetological Conservation and Biology, v. 2, p. 106-112.

Niemiller, M.L., Near, T.J. and Fitzpatrick, B.M., 2012, Delimiting species using multilocus data: diagnosing cryptic diversity in the southern cavefish, Typhlichthys subterraneus (Teleostei: Amblyopsidae): Evolution, v. 66, p. 846-866. doi:10.1111/j.1558-5646.2011.01480.x.

Niemiller, M.L., Taylor, S.J., Slay, M.E., and Hobbs III, H.H., 2019, Biodiversity in the United States and Canada. In: Encyclopedia of Caves, 3rd edition (Culver, D.C., White, W.B., and Pipan, T., eds.): Academic Press, p. 163-177. doi:10.1016/B978-0-12-814124-3.00018-2.

Niemiller, M.L., and Zigler, K.S., 2013, Patterns of cave biodiversity and endemism in the Appalachians and Interior Plateau of Tennessee, USA: PLOS ONE, v. 8, art. e64177, 17 p. doi:10.1371/journal. pone.0064177. doi:10.1371/journal.pone.0064177.

Niemiller, M.L., Zigler, K.S., and Fenolio, D.B., 2013, Cave Life of TAG: A Guide to Commonly Encountered Species in Tennessee, Alabama and Georgia: Huntsville, Alabama, Biology Section of the National Speleological Society, $45 \mathrm{p}$.

Niemiller, M.L., Zigler, K.S., Hart, P.B., Kuhajda, B.R., Armbruster, J.W., Ayala, B.N. and Engel, A.S., 2016, First definitive record of a stygobiotic fish (Percopsiformes, Amblyopsidae, Typhlichthys) from the Appalachians karst region in the eastern United States: Subterranean Biology, v. 20, p.39-50. doi:10.3897/subtbiol.20.9693.

Niemiller, M.L., Zigler, K.S., Ober, K.A., Carter, E.T., Engel, A.S., Moni, G., Philips, T.K. and Stephen, C.D., 2017, Rediscovery and conservation status of six short-range endemic Pseudanophthalmus cave beetles (Carabidae: Trechini): Insect Conservation and Diversity, v. 10, p. 495-501. doi:10.1111/icad.12263.

Niemiller, M.L., Zigler, K.S., Stephen, C.D., Carter, E.T., Paterson, A.T., Taylor, S.J. and Engel, A.S., 2016, Vertebrate fauna in caves of eastern Tennessee within the Appalachians karst region, USA: Journal of Cave and Karst Studies, v. 78, p. 1-24. doi:10.4311/2015LSC0109.

Osbourn, M.S., 2005, The natural history, distribution, and phenotypic variation of cave-dwelling spring salamanders, Gyrinophilus sp. Cope (Plethodontidae), in West Virginia [Master's thesis]: Marshall University, 207 p.

Park, O., 1960, Cavernicolous pselaphid beetles of the United States: American Midland Naturalist, v. 64, p. 66-104. doi:10.2307/2422894.

Pauley, T.K., 1993, Report of the Upland Vertebrates in the New River Gorge National River. Volumes 1-3 (1989-1992). US Department of the Interior, National Park Service.

Peck, S.B., 1973, Systematic revision and the evolutionary biology of the Ptomaphagus (Adelops) beetles of North America (Coleoptera; Leiodidae: Catopinae), with emphasis on cave-inhabiting species: Bulletin of the Museum of Comparative Zoology, v. 145, p. $29-162$.

Peck, S.B., 1982, Occurrence of Ptomaphagus cavernicola in forests in Florida and Georgia (Coleoptera; Leiodidae; Cholevinae): Florida Entomologist, v. 65, p. 378-379. doi:10.2307/3494315.

Peck, S.B., 1988, A review of the cave fauna of Canada, and the composition and ecology of the invertebrate fauna of caves and mines in Ontario: Canadian Journal of Zoology, v. 66, p. 1197-1213. doi:10.1139/z88-176.

Peck, S.B., 1970, The terrestrial arthropod fauna of Florida caves: Florida Entomologist, v. 53, p. 203-207. doi.org/10.2307/3493189.

Peck, S.B., 1989, The cave fauna of Alabama: Part I. The terrestrial invertebrates (excluding insects): National Speleological Society Bulletin, v. 51, p. 11-33.

Peck, S.B., 1995, The cave fauna of Alabama. Part II: The insects: National Speleological Society Bulletin, v. 57, p. 1-19.

Peck, S.B. and Lewis, J.J., 1978, Zoogeography and evolution of the subterranean invertebrate faunas of Illinois and southeastern Missouri: National Speleological Society Bulletin, v. 40, p. 39-63.

Peck, S.B. and Peck, J.H., 1982, Invertebrate fauna of Devils Den, a sandstone cave in northwestern Arkansas: Journal of the Arkansas Academy of Science, v. 36, p. 46-48.

Platnick, N.I., 1999, A revision of the Appalachian spider genus Liocranoides (Araneae, Tengellidae): American Museum Novitates, no. 3285, p. $1-13$.

Poly, W.J., 2001, Nontroglobitic fishes in Bruffey-Hills Creek Cave, West Virginia, and other caves worldwide: Environmental Biology of Fishes, v. 62, p. 73-83. doi:10.1023/A:1011889613271.

Poly, W.J., and Boucher, C.E., 1996, Nontroglobitic fishes in caves: Their abnormalities, ecological classification and importance: The American Midland Naturalist, v. 136, p. 187-198. doi:10.2307/2426644.

Prather, J.W., and Briggler, J.T., 2001, Use of small caves by anurans during a drought period in the Arkansas Ozarks: Journal of Herpetology, v. 35 , p. $675-678$. doi: $10.2307 / 1565910$.

Pruitt, B.C., Jr., 1995, New records of fishes within Florida caves: National Speleological Society Bulletin, v. 57, p. 20-23.

Reeves W., 1999, Cave-dwelling Nesticidae (Araneae) in the southeastern United States: New distribution records and notes on their bionomics: Insecta Mundi, v. 13: p. 93-94.

Reeves, W.K., Jensen, J.B. and Ozier, J.C., 2000, New faunal and fungal records from caves in Georgia, USA: Journal of Cave and Karst Studies, v. 62, p. 169-179.

Reeves, W.K. and McCreadie, J.W., 2001, Population ecology of cavernicoles associated with carrion in caves of Georgia, USA: Journal of Entomological Science, v. 36, p. 305-311. doi:10.18474/0749-8004-36.3.305.

Reeves, W.K. and Paysen, E.S., 1999, Black flies (Diptera: Simuliidae) and a new species of caddisfly (Trichoptera: Hydropsychidae) in a northwestern Georgia cave stream. Entomological News, v. 110, p. 253-259.

Reeves, W.K. and Reynolds, J.W., 1999, New records of cave-dwelling earthworms (Oligochaeta: Lumbricidae, Megascolecidae, and Naididae) and other annelids (Aeolosomatida, Branchiobdellida, and Hirudinea) in the southeastern United States, with notes on their ecology: Megadrilogica, v. 7, p. 65-71.

Reynolds, J.W., 1994, Earthworms of North Carolina (Oligochaeta: Acanthodrilidae, Komarekionidae, Lumbricidae, Megascolecidae, Ocnerodrilidae and Sparganophilidae): Megadrilogica, v. 5, p. 53-72.

Schultz, G.A., 1970, Descriptions of new subspecies of Ligidium elrodii (Packard) comb. nov. with notes on other isopod crustaceans from caves in North America (Oniscoidea). American Midland Naturalist, v. 84, p. 36-45. doi:10.2307/2423724.

Shear, W.A., 1975, The opilionid genera Sabacon and Tomicomerus in America (Opiliones, Troguloidea, Ischyropsalidae): Journal of Arachnology, v. 3, p. 5-29.

Shear, W.A., 2010, The milliped family Trichopetalidae, Part 2: The genera Trichopetalum, Zygonopus and Scoterpes (Diplopoda: Chordeumatida, Cleidogonoidea): Zootaxa, v. 2385, p. 1-62. doi:10.11646/zootaxa.2385.1.1.

Shelley, R.M., 1979, A synopsis of the milliped genus Cambala, with a description of C. minor Bollman (Spirostreptida: Cambalidae): Proc. Biol. Soc. Washington, v. 92, p. 551-571.

Sket, B., 2008, Can we agree on ecological classifications of subterranean animals?: Journal of Natural History, v. 42, n. 21-22, p. $1549-1563$. doi:10.1080/00222930801995762. 
Sokolov, I.M., Carlton, C., and Cornell, J.F., 2004, Review of Anillinus, with descriptions of 17 new species and a key to soil and litter species (Coleoptera: Carabidae: Trechinae: Bembidiini): The Coleopterists Bulletin, v. 58, p. 185-233. doi.org/10.1649/611.

Steeves III, H.R., 1964, The troglobitic asellids of the United States: The hobbsi group: The American Midland Naturalist, v. 71, p. $445-451$. doi:10.2307/2423303.

Studier, E.H., Lavoie, K.H., and Chandler, C.M., 1991, Biology of cave crickets, Hadenoecus subterraneus, and camel crickets, Ceuthophilus stygius (Rhaphidophoridae); Parasitism by hairworms: Journal of the Helminthological Society of Washington, v. 58, p. $248-250$.

Taylor, S.J. and Niemiller, M.L., 2016, Biogeography and conservation assessment of Bactrurus groundwater amphipods (Crangonyctidae) in the central and eastern United States: Subterranean Biology, v. 17, p. 1-29. doi.org/10.3897/subtbiol.17.7298.

USGS, United States Geological Survey, 2019, U.S. Board on Geographic Names, Domestic Names, https://www.usgs.gov/core-science-systems/ngp/board-on-geographic-names/domestic-names.

Venarsky, M.P., Huryn, A.D., and Benstead, J.P., 2012, Re-examining extreme longevity of the cave crayfish Orconectes australis using new mark-recapture data: a lesson on the limitations of iterative size-at-age models: Freshwater Biology, v. 57, p. 1471-1481. doi.org/10.1111/ j.1365-2427.2012.02812.x.

Wynn, A.H., Highton, R. and Jacobs, J.F., 1988, A new species of rock-crevice dwelling Plethodon from Pigeon Mountain, Georgia: Herpetologica, v. 44, p. 135-143.

Yancey, M.E., Mann, N.C., Milne, M.A. and Zigler, K.S., 2018, Egg sacs of Liocranoides Keyserling, 1881 (Araneae: Zoropsidae) cave spiders: Journal of Arachnology, v. 46, p. 553-556. doi:10.1636/JoA-S-17-074.1.

Zhang, J., and Holsinger, J.R., 2003, Systematics of the freshwater amphipod genus Crangonyx (Crangonyctidae) in North America: Virginia Museum of Natural History, Memoir, no. 6, p. 1-274. 



\section{GUIDE TO AUTHORS}

The Journal of Cave and Karst Studies is a multidisciplinary journal devoted to cave and karst research. The Journal is seeking original, unpublished manuscripts concerning the scientific study of caves or other karst features. Authors do not need to be members of the National Speleological Society, but preference is given to manuscripts of importance to North American speleology.

LANGUAGES: The Journal of Cave and Karst Studies uses American-style English as its standard language and spelling style, with the exception of allowing a second abstract in another language when room allows. In the case of proper names, the Journal tries to accommodate other spellings and punctuation styles. In cases where the Editor-inChief finds it appropriate to use non-English words outside of proper names (generally where no equivalent English word exist), the Journal italicizes them. However, the common abbreviations i.e., e.g., et al., and etc. should appear in roman text. Authors are encouraged to write for our combined professional and amateur readerships

CONTENT: Each paper will contain a title with the authors' names and addresses, an abstract, and the text of the paper, including a summary or conclusions section. Acknowledgments and references follow the text. Manuscripts should be limited to 6,000 words and no more than 10 figures and 5 tables. Larger manuscripts may be considered, but the Journal reserves the right to charge processing fees for larger submissions.

ABSTRACTS: An abstract stating the essential points and results must accompany all articles. An abstract is a summary, not a promise of what topics are covered in the paper.

STYLE: The Journal consults The Chicago Manual of Style on most general style issues.

REFERENCES: In the text, references to previously published work should be followed by the relevant author's name and date (and page number, when appropriate) in brackets. All cited references are alphabetical at the end of the manuscript with senior author's last name first, followed by date of publication, title, publisher, volume, and page numbers. Geological Society of America format should be used (see http://www.geosociety.org/documents/gsa/pubs/GSA_RefGuide_Examples.pdf). Please do not abbreviate periodical titles. Web references are acceptable when deemed appropriate. The references should follow the style of: Author (or publisher), year, Webpage title: Publisher (if a specific author is available), full URL (e.g., http://www.usgs. gov/citguide.html), and the date the website was accessed in brackets. If there are specific authors given, use their name and list the responsible organization as publisher. Because of the ephemeral nature of websites, please provide the specific date. Citations within the text should read: (Author, Year).

SUBMISSION: Manuscripts are to be submitted via the PeerTrack submission system at http://www.edmgr.com/ jcks/. Instructions are provided at that address. At your first visit, you will be prompted to establish a login and password, after which you will enter information about your manuscript and upload your manuscript, tables, and figure files. Manuscript files can be uploaded as DOC, WPD, RTF, TXT, or LaTeX. Note: LaTeX files should not use any unusual style files; a LaTeX template and BiBTeX file may be obtained from the Editor-in-Chief. Table files can be uploaded as DOC, WPD, RTF, TXT, or LaTeX files and figure files can be uploaded as TIFF, AI, EPS, or CDR files. Extensive supporting data may be placed on the Journal's website as supplemental material at the discretion of the Editor-in-Chief. The data that are used within a paper must be made available upon request. Authors may be required to provide supporting data in a fundamental format, such as ASCII for text data or comma-delimited ASCII for tabular data.

DISCUSSIONS: Critical discussions of papers previously published in the Journal are welcome. Authors will be given an opportunity to reply. Discussions and replies must be limited to a maximum of 1000 words and discussions will be subject to review before publication. Discussions must be within 6 months after the original article appears.

MEASUREMENTS: All measurements will be in Systeme Internationale (metric) except when quoting historical references. Other units will be allowed where necessary if placed in parentheses and following the SI units.

FIGURES: Figures and lettering must be neat and legible. Figure captions should be on a separate sheet of paper and not within the figure. Figures should be numbered in sequence and referred to in the text by inserting (Fig. $x$ ). Most figures will be reduced, hence the lettering should be large. Photographs must be sharp and high contrast. Figures must have a minimum resolution of 300 dpi for acceptance. Please do not submit JPEG images.

TABLES: See http://caves.org/pub/journal/PDF/Tables.pdf to get guidelines for table layout.

COPYRIGHT AND AUTHOR'S RESPONSIBILITIES: It is the author's responsibility to clear any copyright or acknowledgement matters concerning text, tables, or figures used. Authors should also ensure adequate attention to sensitive or legal issues such as land owner and land manager concerns or policies and cave location disclosures.

PROCESS: All submitted manuscripts are sent out to at least two experts in the field. Reviewed manuscripts are then returned to the author for consideration of the referees' remarks and revision, where appropriate. Revised manuscripts are returned to the appropriate Associate Editor who then recommends acceptance or rejection. The Editorin-Chief makes final decisions regarding publication. Upon acceptance, the senior author will be sent one set of PDF proofs for review. Examine the current issue for more information about the format used. 


\section{Journal of Cave and Karst Studies}

Volume 82 Number 2 June 2020

\section{CONTENTS}

Article

Lampenflora and the Entrance Biofilm in Two Show Caves Comparison of Microbial Community, Environmental, and Biofilm Parameters

Nataša Nikolić, Nikola Zarubica, Bojan Gavrilović, Dragana Predojević, Ivana Trbojević, Gordana Subakov Simić, and Slađana Popovi

Article

Domitius Culsu Sp. Nov. (Araneae, Nesticidae), A New Troglobiont Spider from Italy with Notes on Italian Nesticids of the Genus Domitius Ribera, 2018

Francesco Ballarin

Article

Biogeochemical Investigations of the Speleothem Moonmilk in the Karst Proschalnaya Cave (Far East, Russia)

L. M. Kondratyeva, O. S. Shadrina, Z. N. Litvinenko, and E. M. Golubeva

Article

Enzyme Profiles and Antimicrobial Activities of Bacteria Isolated from the Kadiini Cave, Alanya, Turkey

Nihal Doğruöz-Güngör, Begüm Çandıroğlu, and Gülşen Altuğ

Article

Anthropogenic Impacts on the Bacterial Profile of Yarik Sinkhole in Antalya, Turkey

Nihal Doğruöz-Güngör, Elif Özlem Arslan-Aydoğdu, Emrah Dirmit, and Ender Usuloğlu

Article

Biodiversity from Caves and Other Subterranean Habitats of Georgia, Usa

Kirk S. Zigler, Matthew L. Niemiller, Charles D.R. Stephen, Breanne N. Ayala, Marc A. Milne, Nicholas S. Gladstone, Annette S. Engel, John B. Jensen, Carlos D. Camp, James C. Ozier, and Alan Cressler

Visit us at www.caves.org/pub/journal 